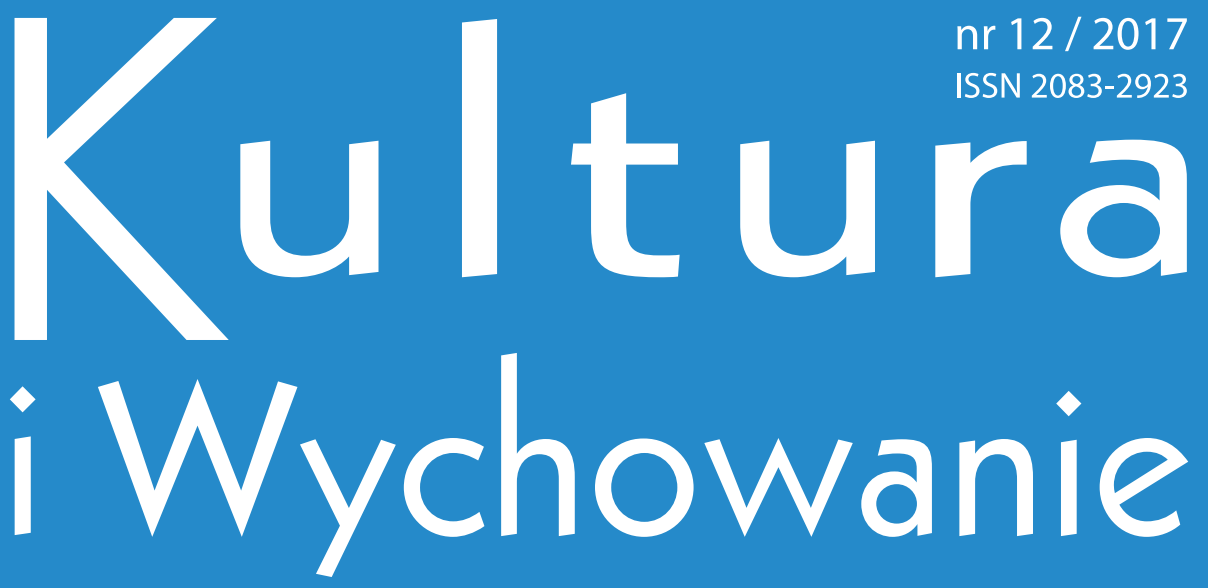

Półrocznik pedagogiczny

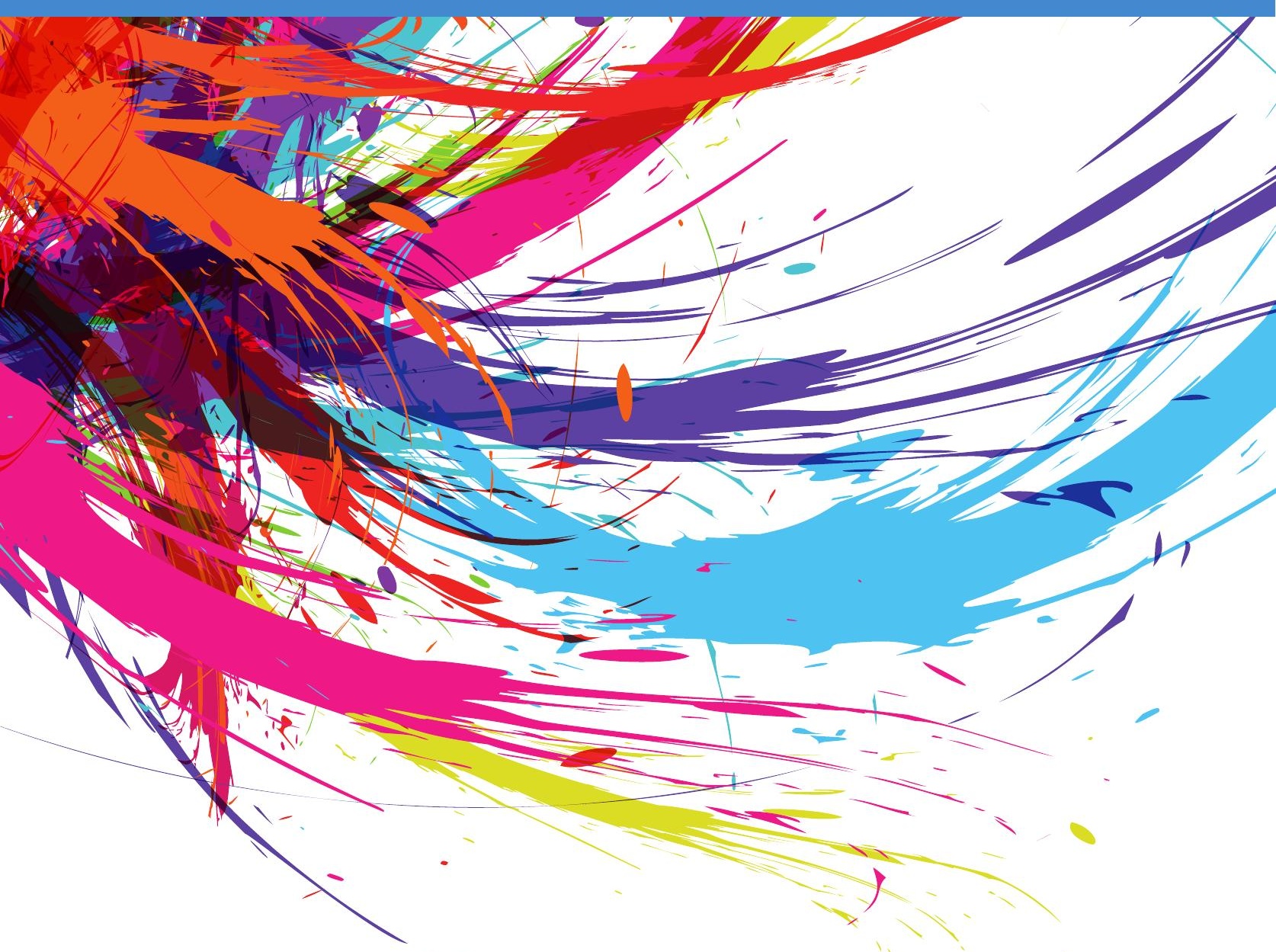

(y) Akademia 

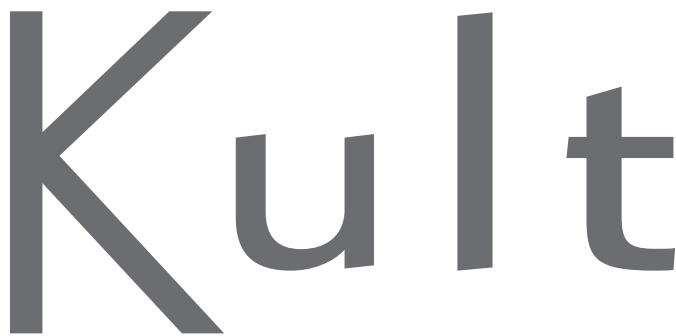

nr 12 / 2017

ISSN 2083-2923

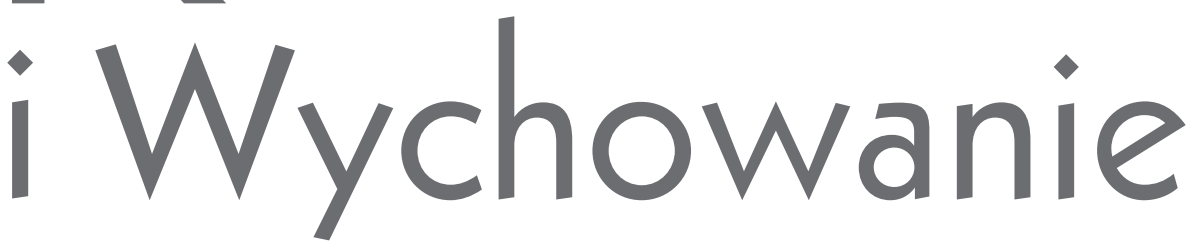

Półrocznik pedagogiczny 
REDAKCJA CZASOPISMA

Redaktor naczelny: dr Krzysztof Kamiński

Z-ca redaktora naczelnego: dr Elżbieta Woźnicka

Sekretarz czasopisma: mgr Dorota Januajtys

\section{RADA NAUKOWA}

\section{Przewodnicząca rady naukowej}

dr hab. Zofia Szarota, prof. UP, Uniwersytet Pedagogiczny im. KEN w Krakowie

\section{Polska rada naukowa}

prof. dr hab. Irena Adamek, Akademia Techniczno-Humanistyczna w Bielsku-Białej prof. dr hab. Edyta Gruszczyk-Kolczyńska, Akademia Pedagogiki Specjalnej im. Marii Grzegorzewskiej w Warszawie prof. dr hab. Bożena Muchacka, Uniwersytet Pedagogiczny im. KEN w Krakowie prof. dr hab. Maria Szyszkowska, Uniwersytet Warszawski, Komitet Prognoz „Polska 2000 Plus” przy Prezydium PAN prof. dr hab. Stanisław Gałkowski, Akademia Ignatianum w Krakowie dr hab. Rafał Godoń, Uniwersytet Warszawski prof. dr hab. Krzysztof Jakubiak, Uniwersytet Gdański prof. dr hab. Lech Mokrzecki, emerytowany prof. UG, Uniwersytet Gdański prof. dr hab. Stanisław Palka, Uniwersytet Jagielloński w Krakowie dr hab. Dariusz Stępkowski, prof. UKSW, Uniwersytet Kardynała Stefana Wyszyńskiego w Warszawie prof. dr hab. Bogdan Szczepankowski, Społeczna Akademia Nauk w Warszawie dr hab. Sławomir Szczyrba, Uniwersytet Kardynała Stefana Wyszyńskiego w Warszawie (WSD w Łodzi)

dr hab. Sławomir Sztobryn, prof. ATH, Akademia Techniczno-Humanistyczna w Bielsku-Białej

\section{Międzynarodowa rada naukowa}

prof. dr hab. Blanka Kudláčová, Uniwersytet w Trnavski w Trnavie, Słowacja prof. dr hab. Naděžda Pelcová, Uniwersytet Karola w Pradze, Czechy prof. dr hab. Irina Predborska, Towarzystwo Filozofii Edukacji, Ukraina prof. dr hab. Ałła Wasyluk, Narodowa Akademia Nauk Pedagogicznych Ukrainy, Ukraina prof. dr hab. Dietrich Benner, Uniwersytet Berliński, Niemcy prof. dr hab. Rudolf Dupkala, Uniwersytet Preszowski w Preszowie, Słowacja 
RECENZENCI „Kultura i Wychowanie” nr 12/2017

dr hab. Małgorzata Bereźnicka, Uniwersytet Pedagogiczny im. KEN w Krakowie dr hab. Beata Bugajska, Uniwersytet Szczeciński

dr Paulina Forma, Uniwersytet Jana Kochanowskiego w Kielcach

dr. hab. Małgorzata Halicka, prof. UB, Uniwersytet w Białymstoku

dr Alicja Klich-Rączka, Uniwersytet Jagielloński w Krakowie

dr hab. Hanna Krauze-Sikorska, prof. UAM, Uniwersytet im. Adama Mickiewicza

w Poznaniu

dr hab. Kinga Łapot-Dzierwa, prof. UP, Uniwersytet Pedagogiczny w Krakowie

dr hab. Jolanta Maćkowicz, Uniwersytet Pedagogiczny w Krakowie

prof. dr hab. Bożena Matyjas, Uniwersytet Jana Kochanowskiego w Kielcach

dr hab. Irena Motow, prof. AJD, Akademia im. Jana Długosza w Częstochowie

dr Anna Szafranek, Państwowa Wyższa Szkoła Informatyki i Przedsiębiorczości w Łomży

dr hab. Zofia Szarota, prof. UP, Uniwersytet Pedagogiczny im. KEN w Krakowie

prof. dr hab. Jolanta Szempruch, Uniwersytet Jana Kochanowskiego w Kielcach

dr hab. Magdalena Szpunar, Uniwersytet Jagielloński w Krakowie

dr hab. Renata Szczepanik, prof. UŁ, Uniwersytet Łódzki

dr hab. Klaudia Węc, prof. Akademii Ignatianum w Krakowie

dr hab. Sławomir Sztobryn, prof. ATH, Akademia Techniczno-Humanistyczna

w Bielsku-Białej

dr hab. Marek Żak, prof. AWF, Akademia Wychowania Fizycznego w Krakowie

\author{
Adres redakcji czasopisma „Kultura i Wychowanie” \\ Akademia Humanistyczno-Ekonomiczna w Łodzi \\ 90-212 Łódź, ul. Sterlinga 26, pok. K 108 \\ e-mail: kulturaiwychowanie@ahe.lodz.pl \\ strona www: www.pedagogika.pl
}




\section{Czasopismo Katedry Pedagogiki}

Akademii Humanistyczno-Ekonomicznej w Łodzi

90-212 Łódź, ul. Sterlinga 26, pok. K 108

e-mail: kulturaiwychowanie@ahe.lodz.pl

strona www: www.pedagogika.pl

(C) Copyright by Akademia Humanistyczno-Ekonomiczna w Łodzi

Łódź 2017

ISSN 2083-2923

Wersją podstawową jest wersja elektroniczna

\section{Projekt graficzny okładki}

Joanna Niekraszewicz

\section{Redaktor prowadzący}

Iwona Morawska

Redakcja językowa i korekta

Anna Woziwoda

Opracowanie typograficzne i skład DTP

Monika Poradecka

Druk i oprawa

OSDW Azymut sp. z o.o., Łódź, ul. Senatorska 31

\section{Wydawnictwo}

\section{Akademii Humanistyczno-Ekonomicznej w Lodzi}

90-212 Łódź, ul. Sterlinga 26

tel. 426315908

wydawnictwo@ahe.lodz.pl

www.wydawnictwo.ahe.lodz.pl 


\section{Spis treści}

Ewa Trojanowska

Gotowość do zadośćuczynienia a empatia u osób odbywających

karę pozbawienia wolności - komunikat z badań

Józef Szubert, Sławomir Szubert, Sylwia Rydz, Izabella Michałowska-Wieczorek, Alicja Szymańska-Paszczuk, Włodzimierz Ziółkowski, Wojciech Wieczorek,

Paweł Szubert

Maksymalne parametry fizjologiczne serca i mięśni kobiet

oraz mężczyzn podczas przejścia na emeryturę

Błażej Kmieciak

Tajemnica psychiatryczna z perspektywy teoretycznych

oraz praktycznych wyzwań: uwagi socjoetyczno-prawne

Sylwia Huczuk

Formy pomocy udzielanej nieletnim - podopiecznym ośrodków

kuratorskich

Karolina Mendecka

Niwelowanie szczególnie trudnej sytuacji dziecka w perspektywie

intersekcjonalnej

Daniel Kukla

Między uczelnią a rynkiem pracy - perspektywy młodych

Marta Motow-Czyż, Irena Motow

Ocena świadomości rodziców w zakresie występowania wad postawy ciała u dzieci. 
Irena Motow, Marta Motow-Czyż

Zasoby adaptacyjne młodzieży zagrożonej wykluczeniem społecznym

Aleksandra Sobczyk-Kubiak

Rozwój osobisty osób starszych jako jeden z obszarów

wykluczenia społecznego

Dariusz Sarzała

Fonoholizm wśród młodzieży szkolnej jako nowa forma zachowań

ryzykownych

Janina Florczykiewicz

Implementacje teoretycznych założeń wychowania estetycznego

w pozainstytucjonalnej edukacji plastycznej w latach 80. XX wieku

na przykładzie działalności grupy pARTner

Dorota Grabowska-Pieńkosz

Emocje w pracy nauczyciela w świetle źródeł pamiętnikarskich

Małgorzata Kunicka

Władza i posłuszeństwo w procesie wychowania (na podstawie

instrukcji Posługa władzy i posłuszeństwo)

Dietrich Benner

Recenzja książki: Thomas Rucker, Komplexität der Bildung.

Beobachtungen zur Grundstruktur bildungstheoretischen Denkens

in der (Spät-)Moderne, Verlag Julius Klinkhardt, Bad Heilbrunn 2014 ....

Irena Motow

Sprawozdanie z konferencji naukowej: Nauki spoteczne

w stużbie dziecka i dorostego

Elżbieta Woźnicka

Sprawozdanie z konferencji Dialog w wychowaniu do wartości 


\section{Contents}

\section{Ewa Trojanowska}

The readiness for redress and the empathy of prisoners

Józef Szubert, Sławomir Szubert, Sylwia Rydz, Izabella Michałowska-Wieczorek, Alicja Szymańska-Paszczuk, Włodzimierz Ziółkowski, Wojciech Wieczorek,

Paweł Szubert

Maximum physiological parameters of the heart and muscles

of women and men during the process of retirement

Błażej Kmieciak

Psychiatric mystery from the perspective of theoretical and practical challenges: socioethical and legal attention

Sylwia Huczuk

Forms of assistance given to minors - the ward

of the curator's center

Karolina Mendecka

Redressing disadvantage: intersectional approach to children's

plight.

Daniel Kukla

Between University and Labour Market - Youth's perspectives

Marta Motow-Czyż, Irena Motow

Assessment of parents' awareness of the occurrence

of postural defects 
Irena Motow, Marta Motow-Czyż

Adaptation resources of the adolescents at risk of social exclusion....

Aleksandra Sobczyk-Kubiak

The area of personal development as one of the areas of exclusion of older people.

Dariusz Sarzała

Phonoholism among school youth as a new form of risky behavior.......

Janina Florczykiewicz

Implementations of theoretical assumptions of aesthetic education

in non-institutional arts education in the 1980's based

on the example of pARTner group activity.

Dorota Grabowska-Pieńkosz

Emotions in the teacher's work in the sources memoir

Małgorzata Kunicka

Authority and Obedience in the Upbrining Process

(Based on the Instruction The Service of Authority and Obedience)

Dietrich Benner

Book review: Thomas Rucker, Komplexität der Bildung.

Beobachtungen zur Grundstruktur bildungstheoretischen Denkens

in der (Spät-)Moderne, Verlag Julius Klinkhardt, Bad Heilbrunn 2014 ....

Irena Motow

Report on the scientific conference "Social sciences in the service of a child and an adult"

Elżbieta Woźnicka

Conference report "Dialogues in upbringing towards values". 
Łódź, 31 maja 2017 r.

Szanowni Państwo,

z satysfakcją informujemy, że Akademia Humanistyczno-Ekonomiczna w Łodzi od roku 2017 będzie kontynuować tradycje wydawnicze międzynarodowego elektronicznego czasopisma naukowego „Kultura i Wychowanie”. Naszą ambicją jest wydawanie czasopisma opiniotwórczego, otwartego i dynamicznie rozwijającego się. Stawiamy sobie dalekosiężne cele, zarówno jeśli chodzi o zawartość merytoryczną czasopisma, jak i pozostałe cechy świadczące o renomie periodyku naukowego.

Obszar zainteresowań czasopisma z założenia ma szeroki zakres. Odwołuje się do zagadnień związanych z interdyscyplinarną relacją kultury i wychowania. Prezentowane wyniki badań naukowych, głównie z obszaru pedagogiki, ujmowane są w dwa bloki tematyczne rozpraw: filozoficzno-historyczne oraz teoretyczno-empiryczne.

„Kultura i Wychowanie” pozostaje półrocznikiem, ukazującym się w maju oraz listopadzie, w formule Open Access - na stronie www.pedagogika.pl. Wersja internetowa jest podstawową formą publikacji. Jednocześnie planujemy druk periodyku w wersji tradycyjnej, której dostępność zapewni Wydawnictwo Naukowe AHE w Łodzi.

Czasopismu naukowemu „Kultura i Wychowanie” przyznano 7 punktów na liście czasopism opublikowanej przez MNiSW (lista B). Proponowane teksty do publikacji można nadsyłać na adres: kulturaiwychowanie@ahe.lodz.pl.

Wszystkim - obecnym oraz przyszłym - czytelnikom życzymy przyjemnej i owocnej lektury; autorom - satysfakcji z publikowania na naszych łamach; współpracownikom - dumy z współtworzenia wyjątkowego dzieła.

$\begin{array}{lll}\text { dr Krzysztof Kamiński } & \text { dr Elżbieta Woźnicka } & \text { prof. Joanna Satoła-Staśkowiak } \\ \text { Redaktor naczelny } & \text { Prodziekan kierunku } & \text { Rektor AHE w Łodzi } \\ \text { czasopisma „Kultura } & \text { Pedagogika AHE } & \\ \text { i Wychowanie” } & \text { w Łodzi }\end{array}$




\author{
Ewa Trojanowska* \\ Uniwersytet Marii Curie-Skłodowskiej w Lublinie \\ e.trojanowska5@gmail.com
}

\title{
Gotowość do zadośćuczynienia a empatia u osób odbywających karę pozbawienia wolności - komunikat z badań
}

\begin{abstract}
Streszczenie: Gotowość do zadośćuczynienia jest niezwykle rzadko podejmowanym przedmiotem badań. Ważnym aspektem są uwarunkowania gotowości do zadośćuczynienia osadzonych, ponieważ mogą wskazywać kierunek oddziaływań resocjalizacyjnych. Celem opracowania jest ustalenie zależności między gotowością do zadośćuczynienia a empatią osób odbywających karę pozbawienia wolności w zakładzie karnym. Badania własne zostały przeprowadzone z wykorzystaniem sondażu diagnostycznego. Grupę badanych stanowi 44 mężczyzn. Wyniki badań własnych wskazują, że u osadzonych występuje pozytywna zależność między ogólną gotowością do zadośćuczynienia a przyjmowaniem punktu widzenia innych osób. Stwierdzono również dodatnią korelację między gotowością do zadośćuczynienia usługowego a przyjmowaniem perspektywy innych osób.
\end{abstract}

Słowa kluczowe: zakład karny, empatia, gotowość do zadośćuczynienia.

\footnotetext{
* Ewa Trojanowska - magister pedagogiki resocjalizacyjnej, doktorantka na Wydziale Pedagogiki i Psychologii Uniwersytetu Marii Curie-Skłodowskiej w Lublinie, absolwentka studiów podyplomowych w zakresie mediacji szkolnej i sądowej, współautor i realizator programu mediacyjnego w zakładach karnych; zainteresowania naukowe: sprawiedliwość naprawcza, mediacja, przemoc w rodzinie, publikacje: A. Lewicka-Zelent, E. Trojanowska, Wzmacnianie zasobów osobistych uczestników warsztatów mediacyjnych - uczniów sprawiających trudności wychowawcze, „Chowanna" 2015, t. 1 (44), s. 251-268; A. Lewicka-Zelent, E. Trojanowska, Poziom asertywności wychowanków schroniska dla nieletnich, „Niepełnosprawność. Półrocznik naukowy. Problemy resocjalizacji penitencjarnej i niedostosowania społecznego" 2012, nr 8, s. 105-123.
} 


\section{Wprowadzenie}

Główny cel wykonywania kary pozbawienia wolności określony został w art. 67 Kodeksu karnego wykonawczego. Brzmi on następująco:

Wykonywanie kary pozbawienia wolności ma na celu wzbudzanie w skazanym woli współdziałania w kształtowaniu jego społecznie pożądanych postaw, w szczególności poczucia odpowiedzialności oraz potrzeby przestrzegania porządku prawnego i tym samym powstrzymania się od powrotu do przestępstwa ${ }^{1}$.

Ustawodawca uściślając termin „społecznie pożądana postawa”, wskazuje na dwie ważne jego składowe, tj. poczucie odpowiedzialności oraz potrzebę przestrzegania porządku prawnego, przy czym nie wyczerpują one jego zakresu znaczeniowego ${ }^{2}$. Dla osiągnięcia powyższego celu prowadzi się zindywidualizowane oddziaływanie na skazanych $w$ ramach określonych $w$ ustawie systemów wykonywania kary, w różnych rodzajach i typach zakładów karnych ${ }^{3}$. Do oddziaływań prowadzonych w warunkach izolacji zakładowej zalicza się m.in.: pracę, zajęcia kulturalno-oświatowe i sportowe ${ }^{4}$. Przywołane poczucie odpowiedzialności można również kształtować u osób odbywających karę pozbawienia wolności poprzez realizację różnorodnych programów resocjalizacyjnych. Odpowiedzialność jest ważna cecha postępowania człowieka, będacca rezultatem sterowania tym postępowaniem $w$ stosunku do innych i samosterowania własnym rozwojem ${ }^{5}$. Jej przejawem jest pełne ponoszenie odpowiedzialności za własne czyny oraz wynikające $z$ nich konsekwencje $e^{6}$. Wyrazem ponoszenia odpowiedzialności przez człowieka skazanego na karę bezwzględnego pozbawienia wolności jest nie tylko poddanie się wyrokowi zasądzonemu przez sąd, ale także zadośćuczynienie lub naprawienie szkody i/lub krzywdy osobie pokrzywdzonej w wyniku dokonanego przez niego przestępstwa. W praktyce jednak niejednokrotnie sprowadza się ono wyłącznie do odbycia kary. Przyjęcie odpowiedzialności za własne działania i ich skutki stanowi podstawę gotowości do zadośćuczynienia sprawców czynów przestępczych, która oznacza, że ma on zamiar (jest chętny i zdecydowany) zrekompensować osobie pokrzywdzonej straty, jakie poniosła, oraz krzywdy, jakich doznała ${ }^{7}$. Bardzo często działania naprawcze na rzecz osób pokrzywdzonych nie są podejmowane przez sprawców czynów przestępczych. Paradoksalnie wielu osadzonych uważa, że to oni

${ }^{1}$ Art. $67 \$ 1$ Kodeks karny wykonawczy.

2 T. Kalisz, A. Kwieciński, Cele izolacji penitencjarnej w perspektywie odrzucenia idei przymusowej resocjalizacji, „Przegląd Prawa i Administracji” 2013, T. XCV, s. 121.

3 Art. 67\$ 2 Kodeks karny wykonawczy.

${ }^{4}$ Art. $67 \$ 3$ Kodeks karny wykonawczy.

${ }^{5}$ Nowy stownik pedagogiczny, W. Okoń (red.), Wydawnictwo Akademickie „Żak”, Warszawa 2001, s. 271.

6 Tamże.

7 A. Lewicka-Zelent, Uwarunkowania gotowości nieletnich do zadośćuczynienia w paradygmacie sprawiedliwości naprawczej, Wydawnictwo UMCS, Lublin 2015, s. 158. 
zostali skrzywdzeni, ponieważ np. długość orzeczonej wobec nich kary pozbawienia wolności jest nieadekwatna do popełnionego przez nich czynu' ${ }^{8}$ Wyniki badań Wojciecha Poznaniaka wskazują, że u skazanych na karę bezwzględnego pozbawienia wolności obniżeniu ulega poczucie winy i odpowiedzialności za własne działania, a wzrasta poczucie krzywdy9. Konsekwencji takiego zjawiska może być wiele. Przykładowo sprawca przestępstwa może skupić się tylko na własnej krzywdzie i nie pamiętać, że negatywne skutki jego działań doświadczają osoby pokrzywdzone ${ }^{10}$, a także może wyrażać chęć zemsty na osobach, które przyczyniły się do jego ukarania ${ }^{11}$. Jedną z przyczyn nieprzyjmowania odpowiedzialności przez osadzonych jest stosowanie technik neutralizacji czynów przestępczych, które służą usprawiedliwianiu czynów niezgodnych z prawem. Należą do nich: kwestionowanie odpowiedzialności, kwestionowanie szkody, kwestionowanie ofiary, potępianie potępiających oraz odwoływanie się do wyższych racji ${ }^{12}$.

Gotowość do zadośćuczynienia jest niezwykle rzadko przedmiotem badań pedagogiki resocjalizacyjnej. Próby określenia poziomu tej gotowości u osadzonych podjęła się Agnieszka Lewicka-Zelent, która swoimi badaniami objęła grupę 213 mężczyzn odbywających karę bezwzględnego pozbawienia wolności. Wyniki tych badań wskazują, że zdecydowana większość badanych nie przejawia chęci podejmowania działań naprawczych na rzecz osób pokrzywdzonych w wyniku dokonanych przez nich przestępstw ${ }^{13}$. Podobne wyniki Lewicka-Zelent uzyskała we współpracy z Ewą Trojanowską, badając kwestię gotowości do zadośćuczynienia za stosowanie przemocy wobec członków rodziny i osób najbliższych. Na podstawie uzyskanych wyników stwierdzono, że ponad $80 \%$ badanych mężczyzn odbywających karę pozbawienia wolności cechowało się niskim poziomem ogólnej gotowości do zadośćuczynienia ${ }^{14}$.

Przedstawione wyniki badań, pomimo tego, że mają charakter eksploracyjny, wskazują, że osoby odbywające karę bezwzględnego pozbawienia wolności nie wykazują chęci podjęcia działań naprawczych wobec osób pokrzywdzonych. Dlatego tak ważne jest, aby w toku oddziaływań resocjalizacyjnych kształtować gotowość do zadośćuczynienia u sprawców przestępstw. Aby można było projektować takie działania, należy wyznaczyć najpierw uwarunkowania gotowości do zadośćuczynienia osób

${ }^{8}$ J. Karbarz-Górka, Rozważania na temat pozytywnych aspektów mediacji po wyroku, [w:] A. Gretkowski, D. Karbarz (red.), Mediacja w teorii i praktyce, Drukarnia Offsetowa Marlex, Stalowa Wola 2009.

9 W. Poznaniak, Zaburzenia w uspołecznianiu u przestępców. Analiza niektórych mechanizmów psychologicznych, Wydawnictwo Naukowe UAM, Poznań 1982.

${ }_{10}$ J. Karbarz-Górka, dz. cyt.

11 W. Poznaniak, dz. cyt.

${ }^{12}$ G. M. Sykes, D. Matz, Techniques of neutralization: A theory of delinquency, „American sociological Review", nr 6/1957, T. 22.

${ }_{13}$ A. Lewicka-Zelent, Gotowość osób pozbawionych wolności do zadośćuczynienia osobom pokrzywdzonym, [książka w druku].

${ }^{14}$ A. Lewicka-Zelent, E. Trojanowska, Gotowość do zadośćuczynienia osób odbywających kare pozbawienia wolności - sprawców przemocy w rodzinie, [artykuł w druku]. 
skazanych na karę bezwzględnego pozbawienia wolności. Próby określenia tych korelatów podjęła się Lewicka-Zelent. Wyniki jej badań wskazują, że u nieletnich gotowość do zadośćuczynienia warunkowana jest m.in. pozytywnymi postawami wobec norm moralnych, poczuciem sprawiedliwości naprawczej oraz empatią ${ }^{15}$. Autorka objęła również badaniami wcześniej wspomnianą 213-osobową grupę mężczyzn odbywających karę pozbawienia wolności. Na podstawie wyników stwierdziła, że u osadzonych najważniejszym predyktorem gotowości do zadośćuczynienia jest składowa empatii, którą stanowi umiejętność przyjmowania perspektywy innych ludzi. Zależność ta ma charakter dodatni, co oznacza, że im wyższy poziom tej umiejętności, tym większa jest gotowość sprawców przestępstw do podjęcia działań naprawczych na rzecz osób pokrzywdzonych. Ponadto Lewicka-Zelent wyznaczyła uwarunkowania jej składowych, tj. gotowości do zadośćuczynienia emocjonalno-materialnego oraz gotowości do zadośćuczynienia usługowego. Stwierdziła, że empatyczna odpowiedź na negatywne przeżycia innych ludzi obniża podejmowanie takich działań naprawczych jak: przeprosiny, przekazanie pieniędzy lub dóbr materialnych, czyli gotowość do zadośćuczynienia emocjonalno-materialnego. Pomiędzy gotowością do zadośćuczynienia usługowego a takimi elementami empatii, jak reagowanie empatyczne w trudnych sytuacjach oraz przyjmowanie perspektywy innych ludzi, występuje natomiast pozytywna zależność, która oznacza, że im większa zdolność do empatyzowania, tym większe jest prawdopodobieństwo, że dana osoba podejmie działania naprawcze o charakterze usługowym wobec osoby pokrzywdzonej ${ }^{16}$.

Jak wskazuje wielu autorów, osoby wykolejone społecznie cechują się niskim poziomem empatii ${ }^{17}$, która według Andrzeja Węglińskiego jest zdolnościa jednostki do emocjonalnej odpowiedzi na spostrzeganie emocjonalnych przeżyć drugiego człowieka ${ }^{18}$. Martin Hoffman uważa, że czynnikiem motywującym do podjęcia działań naprawczych na rzecz osoby pokrzywdzonej jest poczucie winy oparte na empatii ${ }^{19}$. Wrażliwość empatyczna jest w dużej mierze wyuczona, dlatego też można ją rozwijać w toku np. treningów ${ }^{20}$. Potwierdzenie istnienia pozytywnego związku między gotowością do zadośćuczynienia a empatią osób odbywających karę pozbawienia wolności mogłoby nadać kierunek prowadzonym oddziaływaniom penitencjarnym w taki sposób, że rozwijając skłonności do empatyzowania, można by rozwijać gotowość do zadośćuczynienia. W konsekwencji możliwe byłoby kształtowanie poczucia od-

15 A. Lewicka-Zelent, Uwarunkowania..., s. 251-257; 287-294.

${ }_{16}$ A. Lewicka-Zelent, Gotowość..., s. 157-176.

17 Zob. Z. Bartkowicz, Pomoc terapeutyczna nieletnim agresorom i ofiarom agresji w zakładach resocjalizacyjnych, Wydawnictwo AWH Antoni Dudek, Lublin 2001.

18 A. Węgliński, Zrewidowana wersja Kwestionariusza Rozumienia Empatycznego innych ludziKRE II, [w:] A. Wojnarska (red.), Diagnostyka resocjalizacyjna. Wybrane zagadnienia, Wydawnictwo UMCS, Lublin 2011, s. 72.

19 M. L. Hoffman, Empatia i rozwój moralny, GWP, Gdańsk 2006.

${ }^{20}$ Z. Bartkowicz, dz. cyt. 
powiedzialności osadzonych za popełnione przez nich przestępstwa, czego wyrazem stałoby się podejmowanie działań naprawczych wobec osób pokrzywdzonych.

\section{Gotowość do zadośćuczynienia a empatia osób odbywających karę pozbawienia wolności - analiza wyników badań własnych}

Popełnione przestępstwo nie wpływa tylko na osobę pokrzywdzoną, ale także na całą społeczność lokalną, zwłaszcza w sytuacji, gdy jego sprawcą jest członek tej grupy. Zadośćuczynienie czy naprawienie szkody i/lub krzywdy ofierze przestępstwa może wpłynąć nie tylko na zmianę relacji między nią a sprawcą tego czynu, ale także odbudować więzi społeczne ${ }^{21}$. Jak przedstawiono powyżej, przestępcy nie wykazują chęci podejmowania działań naprawczych na rzecz osób, które doznały krzywdy lub szkody w wyniku ich czynów. Z tego powodu tak ważne jest ustalenie, w jaki sposób można rozwijać gotowość osób odbywających karę pozbawienia wolności do zadośćuczynienia osobom pokrzywdzonym.

W związku z powyższym, sformułowany zostały główny problem badawczy: czy występuje (a jeśli tak, to jaka) zależność między gotowością do zadośćuczynienia a empatią osób odbywających karę pozbawienia wolności?

Sformułowano następujące pytania szczegółowe:

1. Jaki jest poziom gotowości do zadośćuczynienia i jej składowych, tj. gotowości do zadośćuczynienia emocjonalno-materialnego oraz zadośćuczynienia usługowego badanych osób?

2. Jaki jest poziom empatii badanych mężczyzn?

3. W jakim stopniu empatia koreluje $\mathrm{z}$ gotowością do zadośćuczynienia u osób odbywających karę pozbawienia wolności?

Do trzeciego pytania badawczego sformułowano następującą hipotezę roboczą:

Założono, że występuje dodatni związek między gotowością do zadośćuczynienia a empatią u osadzonych.

Wyniki badań Lewickiej-Zelent wskazują, że empatia jest korelatem gotowości do zadośćuczynienia nieletnich, co oznacza, że im większą empatią cechuje się młodzież podsądna, tym większą powinna przejawiać gotowość do zadośćuczynienia ${ }^{22}$. Również u osób osadzonych składowa empatii w postaci umiejętności przyjmowania perspektywy innych ludzi stanowi predyktor gotowości do zadośćuczynienia, a zależność ta ma charakter pozytywny ${ }^{23}$.

${ }^{21}$ M. Grudziecka, J. Książek, Mediacja sprawdziła się jako instytucja dla pokrzywdzonych, [w:] L. Mazowiecka (red.), Mediacja karna jako instytucja ważna dla pokrzywdzonego, Wolters Kluwer, Warszawa 2013.

22 A. Lewicka-Zelent, Uwarunkowania..., s. 254-256.

${ }^{23}$ A. Lewicka-Zelent, Gotowość..., s. 198-200. 
Badania własne zostały przeprowadzone z wykorzystaniem metody sondażu diagnostycznego na terenie Zakładu Karnego we Włodawie. Zastosowano dwa narzędzia badawcze: „Skalę Gotowości do Zadośćuczynienia” Lewickiej-Zelent oraz „Indeks Reaktywności Interpersonalnej” Marka H. Davisa w polskiej adaptacji Lewickiej.

„Skala Gotowości do Zadośćuczynienia” służy do określania gotowości osoby badanej do zadośćuczynienia osobie pokrzywdzonej. Narzędzie badawcze składa się z dwunastu twierdzeń. Zostały wyodrębnione dwie podskale: „Zadośćuczynienie Emocjonalno-Materialne” oraz „Zadośćuczynienie Usługowe”. Twierdzenia: 1, 2, 3, 5, 6, 7, 10, 11 wchodzą w skład pierwszej podskali - „Zadośćuczynienia Emocjonalno-Materialnego”, natomiast drugą podskalę, tj. „Zadośćuczynienie Usługowe” tworzą pozycje o numerach: 4, 8, 9 i 12 . Osoby badane są proszone o wskazanie stopnia, w jakim poszczególne twierdzenia odnoszą się do nich. Odpowiedzi udzielają na pięciostopniowej skali (0 - „twierdzenie nie opisuje mnie dobrze”, 4 - „twierdzenie opisuje mnie bardzo dobrze”). Skala posiada ustalone normy stenowe, dzięki którym możliwe jest określenie poziomu zmiennej ${ }^{24}$.

„Indeks Reaktywności Interpersonalnej” Davisa w polskiej adaptacji Lewickiej służy do pomiaru empatii ludzi dorosłych. Narzędzie składa się z następujących podskal, które dotyczą różnych aspektów empatii emocjonalno - poznawczej:

1) fantazji - umożliwiającej pomiar skłonności do przeniesienia się w fikcyjne sytuacje za pomocą wyobraźni;

2) przyjmowania punktu widzenia innych osób;

3) empatycznego reagowania w sytuacjach trudnych - stanowiącego skłonność do odczuwania adekwatnych doznań w związku z zaistniałą sytuacją wywołującą silne negatywne emocje;

4) empatycznej odpowiedzi na negatywne przeżycia innych oznaczającej skłonność do odczuwania przykrości będącej reakcją na zaobserwowane negatywne przeżycia innych ludzi ${ }^{25}$.

Kwestionariusz składa się z 20 twierdzeń. Osoby badane proszone są o wskazanie stopnia na skali pięciopunktowej (od 0 - „nie opisuje mnie dobrze”, do 4 - „opisuje mnie bardzo dobrze"), w jakim podane twierdzenia je opisują. W obrębie każdej podskali sumuje się uzyskane punkty ${ }^{26}$. Narzędzie posiada normy stenowe (oddzielne dla kobiet i mężczyzn), które pozwalają na określenie poziomu empatii emocjonalno-poznawczej ${ }^{27}$.

Na podstawie danych uzyskanych z kwestionariusza ankiety własnej konstrukcji dokonano charakterystyki grupy badanych osób.

24 Tamże, s. 70-71.

25 A. Lewicka, Rozwijanie empatii u studentów pedagogiki specjalnej, Wydawnictwo UMCS, Lublin 2006.

26 M. Davis, Empatia. O umiejętności współodczuwania, GWP, Gdańsk 1999.

27 A. Lewicka, dz. cyt. 
Tabela 1. Charakterystyka grupy badanych

\begin{tabular}{|l|r|r|}
\hline \multicolumn{1}{|c|}{ Zmienne: } & N & \% \\
\hline Wiek: & & 40,91 \\
23-30; & 18 & 40,91 \\
31-40; & 5 & 11,36 \\
$41-50 ;$ & 3 & 6,82 \\
51-60; & & \\
\hline Wykształcenie: & 23 & 52,27 \\
podstawowe; & 15 & 34,09 \\
zawodowe; & 6 & 13,64 \\
średnie; & & \\
\hline Długość aktualnego pobytu w zakładzie karnym: & 13 & 29,55 \\
do roku & 11 & 25,00 \\
powyżej 12 miesięcy do 2 lat & 7 & 15,91 \\
powyżej 2 lat do 4 lat & 9 & 20,45 \\
powyżej 4 lat do 6 lat & 4 & 9,09 \\
powyżej 6 lat & & \\
\hline
\end{tabular}

Grupę badanych stanowiło 44 mężczyzn - recydywistów penitencjarnych. Najmłodszy ankietowany miał 23 lata, a najstarszy - 60 lat. Po 41\% osadzonych znajdowało się w przedziale wiekowym odpowiednio od 23 do 30 roku życia oraz od 31 do 40 lat. $11 \%$ badanych stanowiły osoby w wieku od 41 do 50 roku życia Wiek trzech mężczyzn zawierał się w przedziale wiekowym od 51 do 60 roku życia. Ponad połowa badanych legitymowała się wykształceniem podstawowym. 35\% badanych posiadała wykształcenie zawodowe, a trzy - średnie. 30\% badanych w chwili badania odbywało karę pozbawienia wolności nie dłużej niż 12 miesięcy. 1/4 ankietowanych przebywała w zakładzie karnym dłużej niż rok, ale krócej niż 2 lata. 20\% badanych odbywało karę pozbawienia wolności przynajmniej 4 lata, ale nie dłużej niż 6 lat. Długość pobytu w jednostce penitencjarnej siedmiu osób zawierała się w przedziale od 13 miesięcy do 4 lat, a 3 osoby odbywały karę pozbawienia wolności przynajmniej od sześciu lat.

Do oceny poziomu gotowości do zadośćuczynienia osób odbywających karę pozbawionych wolności wykorzystano „Skalę Gotowości do Zadośćuczynienia” Lewickiej-Zelent. Uzyskane wyniki surowe zostały przeliczone na steny i w ten sposób wyznaczony został poziom zmiennej.

Tabela 2. Poziom gotowości do zadośćuczynienia badanych osób

\begin{tabular}{|c|c|c|}
\hline Poziom: & $\mathrm{N}$ & $\%$ \\
\hline \multicolumn{3}{|c|}{ Gotowość do Zadośćuczynienia Emocjonalno-Materialnego } \\
\hline Poziom niski & 32 & 72,73 \\
\hline Poziom średni & 7 & 15,91 \\
\hline Poziom wysoki & 5 & 11,36 \\
\hline
\end{tabular}




\begin{tabular}{|c|c|c|}
\hline Poziom: & $\mathrm{N}$ & $\%$ \\
\hline & Gotowość do Zadośćuczynienia Usługowego \\
\hline Poziom niski & 11 & 25,00 \\
\hline Poziom średni & 19 & 43,18 \\
\hline Poziom wysoki & 14 & 31,82 \\
\hline & Gotowość do Zadośćuczynienia Ogólnego \\
\hline Poziom niski & 31 & 70,46 \\
\hline Poziom średni & 5 & 11,36 \\
\hline Poziom wysoki & 8 & 18,18 \\
\hline
\end{tabular}

Jak wynika z danych przedstawionych w powyższej tabeli, prawie $3 / 4$ badanych cechuje się niskim poziomem gotowości do zadośćuczynienia emocjonalno-materialnego. $16 \%$ osadzonych przejawia przeciętny jej poziom. Wysoką gotowość do zadośćuczynienia emocjonalno-materialnego wykazuje pięć osób.

Należy stwierdzić, że w zakresie gotowości do zadośćuczynienia usługowego najwięcej osób przejawia jej przeciętny poziom. 32\% badanych cechuje się znaczną gotowością do zadośćuczynienia usługowego. 1/4 recydywistów penitencjarnych przejawia chęć podjęcia działań naprawczych w tym zakresie.

Najwięcej badanych (70\%) nie wykazuje gotowości do zadośćuczynienia. 18\% osadzonych jest chętna pod podjęcia próby zadośćuczynienia osobie pokrzywdzonej, a 5 osób rozważa taką możliwość.

Do oceny poziomu empatii badanych osadzonych wykorzystano „Indeks Reaktywności Interpersonalnej” Davisa w polskiej adaptacji Lewickiej-Zelent. Uzyskane wyniki surowe przeliczono na steny i w ten sposób wyznaczono poziom zmiennej.

Tabela 3. Poziom empatii badanych recydywistów penitencjarnych

\begin{tabular}{|c|c|c|}
\hline Poziom: & N & $\%$ \\
\hline Niski & 9 & 20,45 \\
\hline Średni & 22 & 50,00 \\
\hline Wysoki & 13 & 29,55 \\
\hline
\end{tabular}

Powyżej przedstawione dane świadczą o tym, że połowa badanych cechuje się przeciętnym poziomem empatii. 30\% osadzonych wykazuje jej wysoki poziom, natomiast około $20 \%$ (dziewięć osób) odbywających karę pozbawienia wolności nie przejawia zdolności empatycznych.

W celu sprawdzenia czy istnieje związek między gotowością do zadośćuczynienia a empatią badanych mężczyzn, obliczono korelację między tymi zmiennymi. Uzyskane dane przedstawiono w poniższej tabeli. 
Tabela 4. Korelacja między gotowością do zadośćuczynienia a empatią

\begin{tabular}{|l|c|c|c|c|c|}
\hline & Fantazja & $\begin{array}{c}\text { Przyjmowania } \\
\text { punktu widzenia } \\
\text { innych osób }\end{array}$ & $\begin{array}{c}\text { Empatycznego } \\
\text { reagowania } \\
\text { w sytuacjach } \\
\text { trudnych }\end{array}$ & $\begin{array}{c}\text { Empatycznej } \\
\text { odpowiedzi } \\
\text { na negatywne } \\
\text { przeżycia innych }\end{array}$ & $\begin{array}{c}\text { Empatia } \\
\text { emocjonalno- } \\
\text {-poznawcza }\end{array}$ \\
\hline $\begin{array}{l}\text { Zadośćuczynienie } \\
\text { Emocjonalno- } \\
\text {-Materialne }\end{array}$ & $-0,128$ & 0,274 & $-0,145$ & 0,196 & 0,051 \\
\cline { 2 - 6 } & n. i. & $\sim, 072$ & n. i. & n. i. & n. i. \\
\hline $\begin{array}{l}\text { Zadośćuczynienie } \\
\text { Usługowe }\end{array}$ & 0,361 & 0,261 & 0,051 & $-0,019$ & 0,288 \\
\cline { 2 - 6 } & $0,016^{*}$ & n.i. & n.i. & n.i. & $\sim 0,058$ \\
\hline $\begin{array}{l}\text { Zadośćuczynienie } \\
\text { Ogólne }\end{array}$ & 0,022 & 0,351 & $-0,081$ & 0,131 & 0,161 \\
\cline { 2 - 6 } & n. i. & $0,019^{*}$ & n. i. & n. i. & n. i. \\
\hline
\end{tabular}

* $p<0,05$

$\mathrm{Na}$ podstawie danych przedstawionych w powyższej tabeli można stwierdzić z 95\% prawdopodobieństwem, że w badanej grupie występuje pozytywna korelacja między ogólną gotowością do zadośćuczynienia a przyjmowaniem punktu widzenia innych ludzi. Oznacza to, że ich gotowość do zadośćuczynienia zwiększa się wraz ze zwiększaniem się zdolności przyjmowania perspektywy innych ludzi u osadzonych. Dodatni związek odnotowano również między zadośćuczynieniem usługowym a fantazją - na poziomie istotności $\mathrm{p}<0,05$. Stwierdzono również (na poziomie tendencji statystycznej) występowanie dodatniej korelacji między zadośćuczynieniem usługowym a empatią emocjonalno-poznawczą. Również na poziomie tendencji statystycznej zaobserwowano pozytywny związek między zadośćuczynieniem emocjonalno-materialnym a przyjmowaniem punktu widzenia innych ludzi.

\section{Konkluzje}

Badaniem własnym objęto 44 mężczyzn odbywających karę pozbawienia wolności - recydywistów penitencjarnych. Zdecydowana większość z nich nie przejawia gotowości do podjęcia działań naprawczych względem osoby pokrzywdzonej w wyniku dokonanego przez nich przestępstwa, w tym w formie emocjonalno-materialnej, np. w postaci przeprosin. Uzyskane wyniki są już bardziej zróżnicowane w zakresie gotowości do zadośćuczynienia usługowego. 32\% badanych jest gotowe podjąć pracę, terapię, naukę czy wykonać czynności, które miałyby na celu rekompensatę, a 25\% recydywistów penitencjarnych rozważa taką możliwość. W zakresie empatii emocjonalno-poznawczej połowa osób objętych badaniem przejawia jej przeciętny poziom.

Postawiona hipoteza zakładała, że istnieje dodatni związek między gotowością do zadośćuczynienia a empatią osób odbywających karę pozbawienia wolności. Stwierdzono, że w badanej grupie występuje pozytywna korelacja między ogólną gotowością do zadośćuczynienia a przyjmowaniem punktu widzenia innych ludzi. Potwier- 
dzono również, że istnieje dodatni związek między zadośćuczynieniem usługowym a składową empatii, jaką jest fantazja. Odnotowane związki nie pozwalają stwierdzić, że występuje dodatnia korelacja pomiędzy gotowością do zadośćuczynienia a empatią emocjonalno-poznawczą. Pozytywny związek między zadośćuczynieniem usługowym a empatią występuje jedynie na poziomie tendencji statystycznej. Istotne związki zależnościowe stwierdzono jedynie między dwoma składowymi empatii - fantazją a gotowością do zadośćuczynienia usługowego oraz przyjmowaniem perspektywy innych ludzi a ogólną gotowością do zadośćuczynienia. Nie można zatem stwierdzić, że hipoteza została w całości potwierdzona.

Zadośćuczynienie jest rzadko podejmowanym przedmiotem badań na gruncie nauk społecznych. W związku z tym, trudno porównać uzyskane wyniki badań własnych z dotychczasowymi. Próby określenia uwarunkowań gotowości do zadośćuczynienia nieletnich podjęła się Lewicka-Zelent ${ }^{28}$. Wyniki jej badań wskazują, że gotowość do zadośćuczynienia pozytywnie koreluje z empatią, co częściowo pokrywa się z uzyskanymi wynikami badań własnych. Lewicka-Zelent przeprowadziła również badania eksploracyjne, mające na celu wyznaczenia korelatów gotowości do zadośćuczynienia mężczyzn odbywających karę pozbawienia wolności. Ich wyniki wskazują, że istnieje dodatnia zależność między gotowością do podejmowania działań naprawczych przez sprawców przestępstw a składową empatii - umiejętności przyjmowania perspektywy innych ludzi ${ }^{29}$. W tym zakresie wyniki badań własnych pokrywają się z tymi uzyskanymi przez Lewicką-Zelent. Uzyskano jednak rozbieżne wyniki dotyczące związku między gotowością do zadośćuczynienia usługowego a empatią. W badaniach własnych stwierdzono, że występuje dodatnia korelacja między zadośćuczynieniem usługowym a fantazją - składową empatii. Lewicka-Zelent wyznaczyła reagowanie empatyczne $\mathrm{w}$ trudnych sytuacjach oraz przyjmowanie perspektywy innych ludzi jako uwarunkowania tego rodzaju gotowości do zadośćuczynienia ${ }^{30}$. Uzyskane różnice wyników badań mogą wynikać m.in. ze zdecydowanej rozbieżności w zakresie liczebności grup badanych. Mimo to statystyczny związek między ogólną gotowością do zadośćuczynienia a umiejętnością przyjmowania perspektywy innych ludzi istotnie może świadczyć o jego sile, którą należy potwierdzić w dalszych badaniach.

Podjęte badania mają charakter eksploracyjny. W związku z tym należy podejmować kolejne (zwłaszcza uwzględniające losowy dobór grup badanych), mające na celu nie tylko określenie poziomu gotowości do zadośćuczynienia osób, które dokonały przestępstw, ale również uwarunkowań tejże gotowości, aby można było w zakładach karnych projektować działania zmierzające do rozwijania gotowości do podjęcia działań naprawczych na rzecz osób pokrzywdzonych w wyniku przestępstw.

\footnotetext{
28 A. Lewicka-Zelent, Uwarunkowania..., s. 251-257.

${ }^{29}$ A. Lewicka-Zelent, Gotowość..., s. 198-200.

30 Tamże.
} 


\section{Bibliografia}

Bartkowicz Z., Pomoc terapeutyczna nieletnim agresorom $i$ ofiarom agresji $w$ zakładach resocjalizacyjnych, Wydawnictwo AWH Antoni Dudek, Lublin 2001.

Davis M., Empatia. O umiejętności współodczuwania, GWP, Gdańsk 1999.

Grudziecka M., Książek J., Mediacja sprawdziła się jako instytucja dla pokrzywdzonych, [w:] L. Mazowiecka (red.), Mediacja karna jako instytucja ważna dla pokrzywdzonego, Wolters Kluwer, Warszawa 2013, s. 508-525.

Hoffman M. L., Empatia i rozwój moralny, GWP, Gdańsk 2006.

Lewicka A., Rozwijanie empatii u studentów pedagogiki specjalnej, Wydawnictwo UMCS, Lublin 2006.

Lewicka-Zelent A., Uwarunkowania gotowości nieletnich do zadośćuczynienia w paradygmacie sprawiedliwości naprawczej, Wydawnictwo UMCS, Lublin 2015.

Lewicka-Zelent A., Gotowość osób pozbawionych wolności do zadośćuczynienia osobom pokrzywdzonym, [książka w druku].

Lewicka-Zelent A., Trojanowska E., Gotowość do zadośćuczynienia osób odbywających karę pozbawienia wolności - sprawców przemocy $w$ rodzinie, [artykuł w druku].

Kalisz T., Kwieciński A., Cele izolacji penitencjarnej w perspektywie odrzucenia idei przymusowej resocjalizacji, „Przegląd Prawa i Administracji” 2013, T. XCV, s. 117-129.

Karbarz-Górka J., Rozważania na temat pozytywnych aspektów mediacji po wyroku, [w:] A. Gretkowski, D. Karbarz (red.), Mediacja w teorii i praktyce, Drukarnia Offsetowa Marlex, Stalowa Wola 2009, s. 167-174.

Kodeks karny wykonawczy, Ustawa z dnia 6 czerwca 1997 r. (Dz.U. 1997 nr 90 poz. 557 z późn. zm.).

Nowy słownik pedagogiczny, W. Okoń (red.), Wydawnictwo Akademickie „Żak”, Warszawa 2001.

Poznaniak W., Zaburzenia w uspołecznianiu u przestępców, Analiza niektórych mechanizmów psychologicznych, Wydawnictwo Naukowe UAM, Poznań 1982.

Sykes G. M., Matz D., Techniques of neutralization: A theory of delinquency, „American sociological Review", nr 6/1957, T. 22, s. 667-669.

Węgliński A., Zrewidowana wersja Kwestionariusza Rozumienia Empatycznego innych ludzi - KRE II, [w:] A. Wojnarska (red.), Diagnostyka resocjalizacyjna. Wybrane zagadnienia, Wydawnictwo UMCS, Lublin 2011, s. 67-90. 


\title{
Prisoners' empathy and their readiness for redress
}

Abstract: Preparedness for redress is an extremely rare subject of research. An important aspect is the willingness of prisoners to compensate, as this may signal progress in their resocialization. The aim of the study is to determine the relationship between the willingness to undertake redress and the empathy of those who are sentenced to imprisonment. The research was conducted using a diagnostic survey. The group of respondents consisted of 44 men. The results of the research indicated that among the prisoners there was a positive relationship between a general readiness for reparation and an understanding of the viewpoint of others. There was also a positive correlation between willingness to redress in the form of service and understanding the viewpoint of others.

Keywords: penitentiary, empathy, readiness for redress.

\begin{abstract}
About the author: Ewa Trojanowska - MA in resocialization pedagogy, doctoral student at Maria Curie-Skłodowska University in Lublin, graduate of postgraduate studies in school and forensic mediation, co-author and facilitator of mediation programmess in penientiary insitutuins; academic interests: corrective justice, mediation, domestic violence, publications: A. Lewicka-Zelent, E. Trojanowska, Wzmacnianie zasobów osobistych uczestników warsztatów mediacyjnych - uczniów sprawiających trudności wychowawcze, „Chowanna” 2015, t. 1 (44), s. 251-268; Lewicka-Zelent, E. Trojanowska, Poziom asertywności wychowanków schroniska dla nieletnich, „Niepełnosprawność. Półrocznik naukowy. Problemy resocjalizacji penitencjarnej i niedostosowania społecznego" 2012, nr 8, s. $105-123$.
\end{abstract}




\author{
Józef Szubert ${ }^{*}$ \\ Wyższa Szkoła Informatyki i Umiejętności w Łodzi \\ jszubert@onet.eu
}

Sławomir Szubert ${ }^{* *}$, Sylwia Rydz $z^{* * *}$, Izabella Michałowska-Wieczorek ${ }^{* * * *}$, Alicja Szymańska-Paszczuk ${ }^{* * * * *}$, Włodzimierz Ziółkowski ${ }^{* * * * * *}$, Wojciech Wieczorek ${ }^{* * * * * *}$, Paweł Szubert ${ }^{* * * * * * * *}$

\title{
Maksymalne parametry fizjologiczne serca i mięśni kobiet oraz mężczyzn podczas przejścia na emeryturę
}

\begin{abstract}
Streszczenie: Starzenie się jest procesem fizjologicznym, który przejawia się wraz z wiekiem. Charakteryzuje się stałym zmniejszaniem maksymalnych parametrów fizjologicznych oraz mniejszą zdolnością do regeneracji i adaptacji.

Wyróżnia się trzy typy starzenia się: 1) zdrowy, 2) zwykły 3) chorobowy. Pierwsze dwa typy starzenia zalicza się do fizjologicznego starzenia się, które obejmują około 65\% kobiet i mężczyzn.

Takie starzenie jest badane przez autorów pracy przy wyznaczaniu maksymalnych parametrów fizjologicznych serca i mięśni kobiet oraz mężczyzn podczas przejścia na emeryturę. Obecnie osoby, które osiągają wiek emerytalny i starzeją się fizjologicznie w większości nie są niedołężnymi starcami, a wręcz przeciwnie- najczęściej funkcjonują normalnie.
\end{abstract}

\footnotetext{
* Dr Józef Szubert - nauczyciel akademicki.

** Dr Sławomir Szubert - Wyższa Szkoła Informatyki i Umiejętności w Łodzi, nauczyciel akademicki.

${ }^{* * *}$ Dr Sylwia Rydz - Prorektor Akademii Humanistyczno-Ekonomicznej w Łodzi, nauczyciel akademicki.

**** Dr Izabella Michałowska-Wieczorek - Akademia Humanistyczno-Ekonomiczna w Łodzi, nauczyciel akademicki.

${ }^{* * * * *}$ Mgr Alicja Szymańska-Paszczuk - Wyższa Szkoła Informatyki i Umiejętności w Łodzi, nauczyciel akademicki.

${ }_{* * * x+* *}$ Dr prof. WSIU Włodzimierz Ziółkowski - Dziekan Wydziału Pedagogiki i Promocji Zdrowia w Wyższej Szkole Informatyki i Umiejętności w Łodzi.

${ }^{* * * x+* * *}$ Dr Wojciech Wieczorek - Uniwersytet Łódzki, nauczyciel akademicki.

Paweł Szubert - student Politechniki Łódzkiej.
} 
Celem pracy jest wyznaczenie parametrów fizjologicznych serca i mięśni kobiet oraz mężczyzn o przeciętnej wydolności fizycznej w wieku emerytalnym - 67 lat oraz dla kobiet $\mathrm{w}$ wieku 60 lat i mężczyzn w wieku 65 lat.

W przypadku kobiet największy ubytek wartości parametrów fizjologicznych przyjmuje maksymalna siła mięśni (F max), a najmniejszy objętość wyrzutowa serca (SVmax). Średni ubytek maksymalnych parametrów fizjologicznych kobiet wynosi: dla wieku 60 lat $\rightarrow$ $(-13,45 \%)$, dla wieku 67 lat $\rightarrow(-18,15 \%)$, a dla wieku 75 lat $\rightarrow(-24,4 \%)$.

W przypadku dla mężczyzn największy ubytek wartości parametrów fizjologicznych przyjmuje pułap tlenowy ( $\left.\mathrm{Vo}_{2} \max \right)$, a najmniejszy różnica tętniczo-żylna wysycenia krwi tlenem (AVDmax). Średni ubytek maksymalnych parametrów fizjologicznych mężczyzn wynosi: dla wieku 65 lat $\rightarrow(-18,2 \%)$, dla wieku 67 lat $\rightarrow(-19,7 \%)$, a dla wieku 75 lat $\rightarrow$ $(-26,35 \%)$.

Wyznaczone maksymalne parametry fizjologiczne serca i mięśni kobiet oraz mężczyzn pozwalają na dokładną, obiektywną i ilościową ocenę stanu zdrowia odchodzących na emeryturę.

Słowa kluczowe: przejście na emeryturę, maksymalne parametry fizjologiczne serca i mięśni.

\section{Wstęp}

Dwa procesy w życiu człowieka: wykonywanie pracy oraz starzenie się przebiegają równolegle i wzajemnie na siebie oddziałują. Praca polega na wydatkowaniu określonej energii mięśni, mózgu i innych narządów. Nadmiernie ciężki, wieloletni wysiłek fizyczny wpływa szczególnie niekorzystnie na organizm człowieka, jego poszczególne narządy i układy. Starzenie się jest procesem fizjologicznym, który postępuje wraz z wiekiem i charakteryzuje się stałym zmniejszaniem maksymalnych parametrów fizjologicznych oraz zdolności do regeneracji i adaptacji ${ }^{1}$.

Wyróżnia się trzy typy starzenia się:

${ }^{1}$ Zob.: P. M. Conn, Handbook of models for human aging, Elsevier, New York 2006; L. C. L. Correia i in., Attenuated cardiovascular reserve during prolonged submaximal cycle exercise in healthy older subjects, JACC, $\mathrm{nr}$ 40(7)/2002, s. 1290-1297; J. L. Fleg i in., Impact of age on the cardiovascular response to dynamic upright exercise in healthy men and women, J Appl Physiol, $\mathrm{nr}$ 78(3)/1995, s. 890-900; A. Guyton, J. Hall, Textbook of medical physiology, W. B. Saunders, Philadelphia 2005; D. Houghton i in., The effect of age on the relationship between cardiac and vascular, Mech Ageing Dev, $\mathrm{nr}$ 153/2015, s. 1-6; A. S. Jackson i in., Longitudinal changes in body composition associated with healthy ageing: men, aged 20-96 years, British Journal of Nutrition, nr 107(7)/2012, s. 1085-1091; W. L. Kenney i in., Physiology of sport and exercise, Human Kinetics, Champaign 2015; S. Kozłowski, K. Nazar, Wprowadzenie do fizjologii klinicznej, PZWL, Warszawa 1999; R. D. Pollock i in., An investigation into the relationship between age and physiological function in highly active older adults, J Physiol, nr 593(3)/2015, s. 657-680.

${ }^{2}$ Zob.: M. Laskowska-Szcześniak, E. Kozak-Szkopek, Uwarunkowania pomyślnego starzenia, Forum Medycyny Rodzinnej, nr 7(6)/2013, s. 287-294; A. Marchewka i in., Fizjologia starzenia się, PWN, Warszawa 2013; S. A. Plowman, D. L. Smith, Exercise physiology, Lippincott Williams \& Wilkins, Philadelphia 2014; G. C. Sieck, Physiology of aging, J Appl Physiol, nr 95 (4)/2003, 
1. Zdrowy - osoby starzejące się w ten sposób są pogodne i zadowolone z życia, postrzegają się jako młodsze, nie stronią od kontaktów z młodym pokoleniem, są sprawni umysłowo, optymistycznie nastawieni do ludzi; aktywnie uczestniczą w życiu otoczenia, co umożliwia im brak ograniczeń funkcji. Nie chorują przewlekle.

2. Zwykły - najczęstszy typ starzenia się. W funkcjonowaniu osoby starzejącej się występują dyskretne działania czynników patologicznych (brak więc „otwartej" patologii - przeciwdziała jej istnienie znacznych rezerw funkcjonalnych, przede wszystkim w układzie oddechowym i sercowo-naczyniowym).

3. Chorobowy - charakteryzuje się widocznym udziałem chorób, utrudniającym normalne funkcjonowanie osoby starzejącej się.

Pierwsze dwa typy starzenia, które występują u około $65 \%$ kobiet i mężczyzn, zalicza się do fizjologicznego starzenia się. Ono właśnie badane jest przez autorów niniejszej pracy w celu wyznaczenia maksymalnych parametrów fizjologicznych serca i mięśni kobiet oraz mężczyzn o przeciętnej wydolności fizycznej podczas przejścia na emeryturę. Wiek emerytalny jest osiągany przez ludzi, którzy wcześniej wkroczyli na rynek pracy, dzięki czemu stali się członkami systemu emerytalnego. Obecnie wiele osób, które osiąga wiek emerytalny i starzeje się fizjologicznie, nie jest niedołężnymi starcami; wręcz przeciwnie - najczęściej funkcjonują normalnie ${ }^{3}$.

Moment przejścia na emeryturę jest regulowany przez państwo. W 2013 roku podjęto decyzję o ustaleniu równego wieku emerytalnego dla kobiet i mężczyzn zdecydowano o wydłużeniu go do wieku 67 lat. Od października 2017 r. wiek emerytalny dla kobiet został obniżony na 60 lat, zaś dla mężczyzn na 65 lat. Polskie prawo stanowi jednocześnie, że pracownika „siłą ” na emeryturę wysłać nie można, co jest zgodne z dyrektywami UE dotyczącymi dyskryminacji ze względu na wiek. Ani PESEL, ani uzyskanie prawa do świadczeń emerytalnych nie jest więc wystarczającym powodem, by pracownika się pozbyć ${ }^{\text {. }}$

s. 1333-1334; A. W. Taylor, M. J. Johnson, Physiology of exercise and healthy aging, Human Kinetics Champaign IL, New York 2008; J. A. Żołądź, J. Majerczak, Wplyw starzenia się na wydolność fizyczną człowieka, [w:] J. Marchewka, J. A. Żołądź, Z. Dąbrowski (red.), Fizjologiczne procesy starzenia, PWN, Warszawa 2011.

${ }^{3}$ Zob.: A. Duda, Powinniśmy wybierać moment przejścia na emeryturę, AJP. 11.05.2017. Warszawa; Konfederacja Lewiatan, Informacja prasowa, 8.12.2016, Warszawa; P. Kubicki, Oswoić starość czy eutanazję?, Instytut Obywatelski, Warszawa 2012; W. Otto, M. Bitner, Konsekwencje obniżenia wieku emerytalnego, Warszawa 2016; Raport z badań: Dezaktywacja osób w wieku około emerytalnym, Departament Analiz Ekonomicznych i Prognoz, Ministerstwo Pracy i Polityki Społecznej, Warszawa 2008; J. Zalewska, Od emerytury do trzeciego wieku: starość w czasach nowożytnych, Warszawa 2011.

${ }^{4}$ Zob.: F. Chybalski, System emerytalny: definicje, cele, klasyfikacje, Warszawa 2016; A. Duda, dz. cyt.; C. Kochalski, Przejście na emeryturę to prawo, nie obowiązek, „Ubezpieczenia Emerytalne i Rentowe", 31.05.2017; Lex.pl: Wyrok z dnia 16 lipca 2010 r. Sąd Rejonowy we Wrocławiu IV JP 300/2009 oraz wyrok Okręgowego Sądu Administracyjnego: OSA 2012/4/112-134; E. Rafal- 
Znaczna część ekspertów wskazuje, że wiek 60 lat jest zbyt wczesny i należy granicę wieku emerytalnego przesunąć przynajmniej do 65 roku życia, a najlepiej by tą granicą był 70, a nawet 75 rok życia. Wielu badaczy zakłada konieczność wydłużenia czasu aktywności zawodowej. Jako powody podaje się m.in.: statystyczne wydłużanie się trwania życia ludzkiego, malejąca liczba osób w wieku produkcyjnym oraz rosnąca populacja emerytów. Grozi to destabilizacją systemu emerytalno-rentowego, a w konsekwencji załamaniem się finansów państwa ${ }^{5}$.

Celem pracy jest wyznaczenie parametrów fizjologicznych serca i mięśni kobiet oraz mężczyzn o przeciętnej wydolności fizycznej w wieku emerytalnym z wcześniejszej ustawy (67 lat) oraz z obecnie obowiązujących aktów prawnych (dla kobiet w wieku 60 lat i mężczyzn w wieku 65 lat).

\section{Materiał i metody}

W poprzedniej pracy ${ }^{6}$, w oparciu o polskie i światowe dane empiryczne, stwierdzono wpływ starzenia się na wartości parametrów fizjologicznych człowieka podczas przejścia od młodości do wieku starszego ${ }^{7}$. Zmiany mogą być analizowane poprzez obserwacje długofalowe (longitudinalne) bądź przekrojowe ${ }^{8}$. W badaniach longitudinalnych autorzy pracy brali pod uwagę dwa typy starzenia się: a) typ zdrowego starzenia się, b) typ zwykłego starzenia się. Aby wyznaczyć maksymalne parametry fizjologiczne kobiet i mężczyzn o dużej wydolności fizycznej i przeciętnej wydolności fizycznej: maksymalny minutowy pobór tlenu $\left(\mathrm{Vo}_{2 \max }\right)$, maksymalną pojemność minutową serca $\left(\mathrm{CO}_{\max }\right)$, maksymalną częstość pracy serca $\left(\mathrm{HR}_{\max }\right)$, maksymalną objętość wyrzutową

ska, Przejście na emeryturę jest nasza decyzja i wyborem, NSZZ „Solidarność”, Kraków 18.05.2017; Raport z badań, dz. cyt.

${ }^{5}$ Zob.: Konfederacja Lewiatan, dz. cyt.; P. Kubicki, dz. cyt., G. Marciniak, Wyzwania polityki ludnościowej wobec prognoz demograficznych dla Polski i Europy, Główny Urząd Statystyczny, Wrocław 2015; J. Mordasiewicz, 10 tys. zł dla emeryta za późniejsze przejście na emeryturę, Konfederacja Lewiatan, Warszawa 16.03.2017; Raport z badań, dz. cyt.

${ }^{6}$ J. Szubert i in., Innowacyjna metoda wyznaczania maksymalnych parametrów fizjologicznych serca kobiet i mężczyzn podczas przejścia od młodości do wieku starszego, II Konferencja Naukowa Profesjonalizacja Kreatywności: Kreatywne Myślenie-Kreatywne Działanie, Lublin 2017.

7 Zob.: A. Daskalski, Handbook of research on systems Biology applications in medicine. Medical Information Science Reference, New York 2009; J. L. Fleg i in., dz. cyt.; D. Houghton i in., dz. cyt.; W. L. Kenney i in., dz. cyt.; E. G. Lakatta, dz. cyt.; S. A. Plowman, D. L. Smith, dz. cyt.; M. Rogasta, Textbook of clinical hemodynamics, Saunders Elsevier, Philadelphia 2008; A. Sessions, A. J. Engler, Mechanical regulation of cardiac aging in model systems, "Circulation Research", nr 118(10)/2016, s. 1553-1562.

${ }^{8}$ Zob.: D. B. Dill i in., Responses to exercise as related to age, J Appl Physiol, nr 12(2)/1958, s. 195 196; K. F. Ferraro, J. A. Kelley-Moore, A half century of longitudinal methods in social gerontology, "The Journals of Gerontology: Series B”, nr 58/2003, s. 264-270; M. Hollenberg i in., Longitudinal changes in aerobic capacity: implications for concepts of aging, J Gerontol A Biol Sci Med Sci, nr 61(8)/2006, s. 851858; A. S. Jackson i in., dz. cyt.; R. D. Lindeman i in., Longitudinal studies on the rate of decline in renal function with age, J Am Geriatr Soc, nr 33(4)/1985, s. 278-285; S. A. Plowman, D. L. Smith, dz. cyt. 
$\operatorname{serca}\left(\mathrm{SV}_{\max }\right)$ oraz maksymalną różnicę tętniczo-żylną wysycenia krwi tlenem $\left(\mathrm{AVD}_{\max }\right)$, autorzy pracy korzystali z różnych danych, dostępnych w polskich i zagranicznych źródłach? . Znając światowe dane doświadczalne dotyczące różnych badań przekrojowych i longitudinalnych zmian maksymalnych parametrów fizjologicznych kobiet i mężczyzn w procesie starzenia się, stosując analizę matematyczną oraz modelowanie matematyczne i symulację komputerową, opracowano innowacyjne, kompleksowe i wiarygodne metody wyznaczania ww. maksymalnych parametrów fizjologicznych kobiet i mężczyzn o dużej oraz przeciętnej wydolności fizycznej. Wyniki przeprowadzonych badań przedstawiono w postaci graficznej (za pomocą wykresów), analitycznej (za pomocą równań) oraz tabelarycznej. W obecnej pracy wykorzystano tylko postać graficzną badań (wykresy) dotyczących kobiet i mężczyzn o przeciętnej wydolności fizycznej.

\section{Wyniki badań}

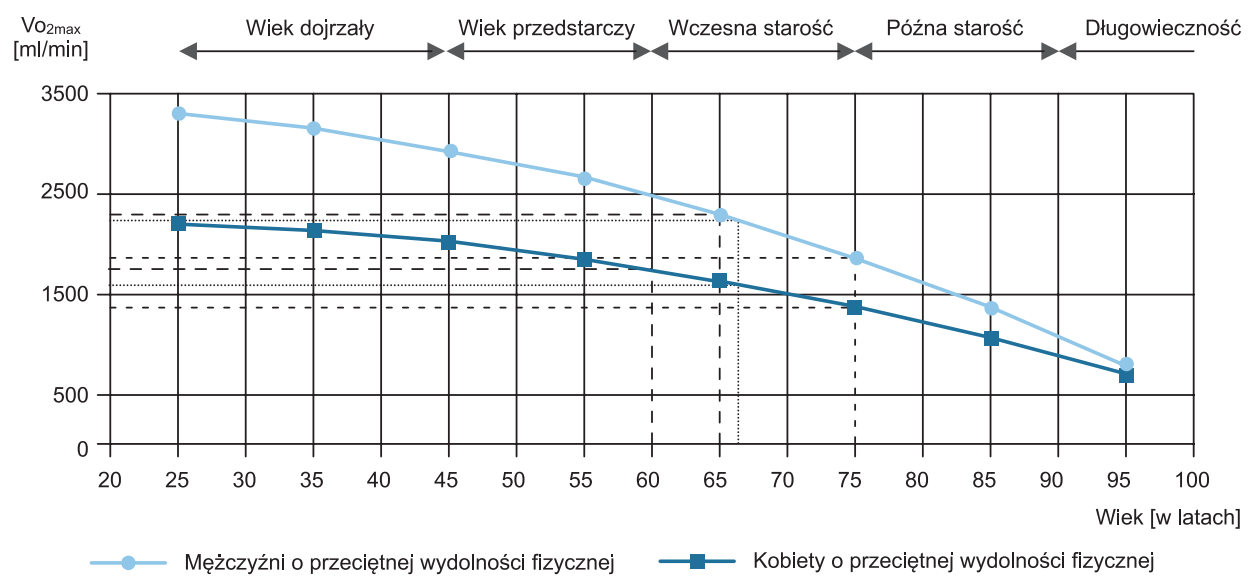

Ryc. 1. Zmiany $\mathrm{Vo}_{2 \max }$ u mężczyzn i u kobiet o przeciętnej wydolności fizycznej przy przejściu od młodości do wieku starszego, wraz z zaznaczonymi wartościami $\mathrm{Vo}_{2 \max }$ podczas przejścia na emeryturę.

${ }^{9}$ Zob.: A. Daskalski, dz. cyt.; D. B. Dill i in., dz. cyt.; P. Era, T. Rantanen, Changes in physical capacity and sensory/psychomotor functions from 75 to 80 years of age and from 80 to 85 years of age a longitudinal study, Scand J Med Soc Supl, nr 53/1997, s. 25-43; J. L. Fleg i in., Accelerated longitudinal decline of aerobic in healthy older adults, "Circulation", nr 112(5)/2005, s. 624-682; D. Houghton, dz. cyt.; A. S. Jackson i in., dz. cyt.; B. M. Kaess i in., Aortic stiffness, blood pressure progression and incident hypertension, JAMA., nr 308(9)/2012, s. 875-881; W. L. Kenney i in., dz. cyt.; S. Kozłowski, K. Nazar, dz. cyt., A. Marchewka i in., dz. cyt.; S. A. Plowman, D. L. Smith, dz. cyt. 


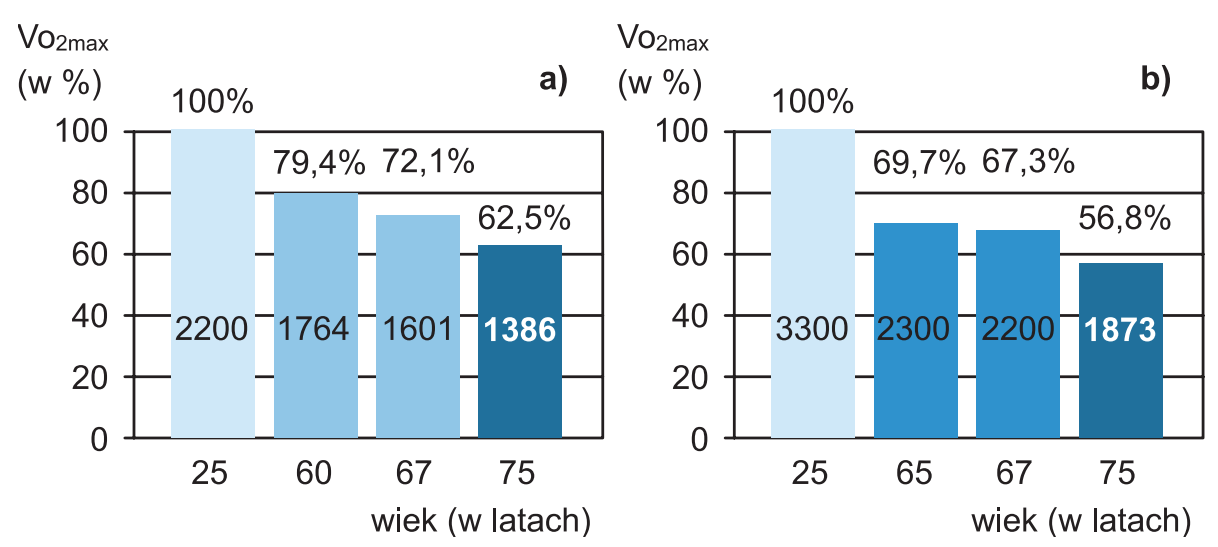

Ryc. 2. Maksymalne parametry $\mathrm{Vo}_{2 \max }$ podane $\mathrm{w}$ wartościach bezwzględnych i w procentach w stosunku do wartości wieku 25 lat (która wynosi 100\%), podczas przejścia na emeryturę:

a) kobiet w wieku 60 i 67 lat, b) mężczyzn w wieku 65 i 67 lat, oraz dla wieku 75 lat, który rozpoczyna późną starość.

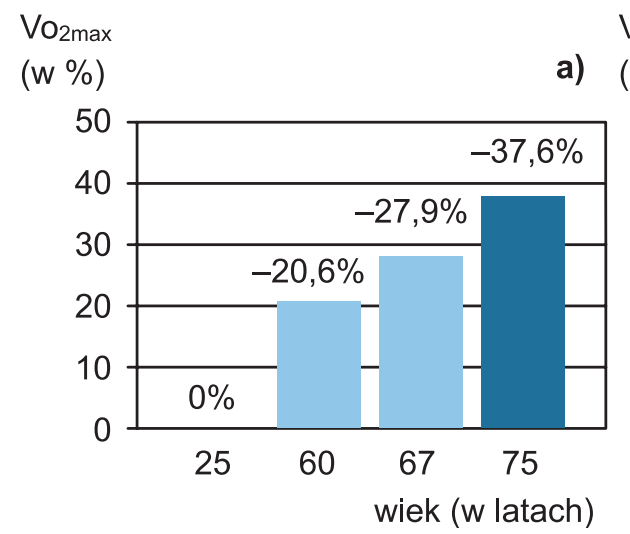

$\mathrm{Vo}_{2 \max }$

a) $(\mathrm{w} \%)$

b)

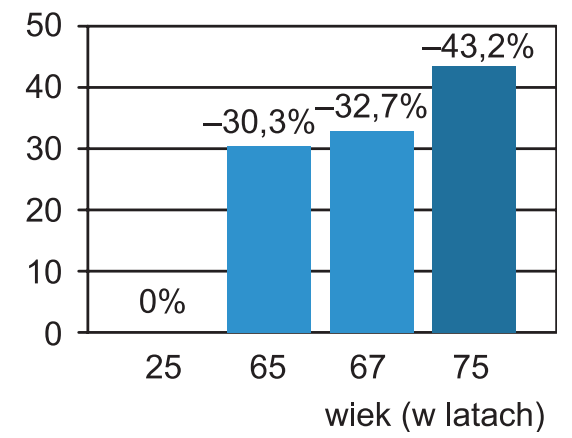

Ryc. 3. Ubytki parametrów $\mathrm{Vo}_{2 \max }$ podane w procentach w stosunku do wartości, która wynosi 0\% w wieku 25 lat, podczas przejścia na emeryturę: a) kobiet w wieku 60 i 67 lat, b) mężczyzn w wieku 65 i 67 lat, oraz dla wieku 75 lat, który rozpoczyna późną starość. 


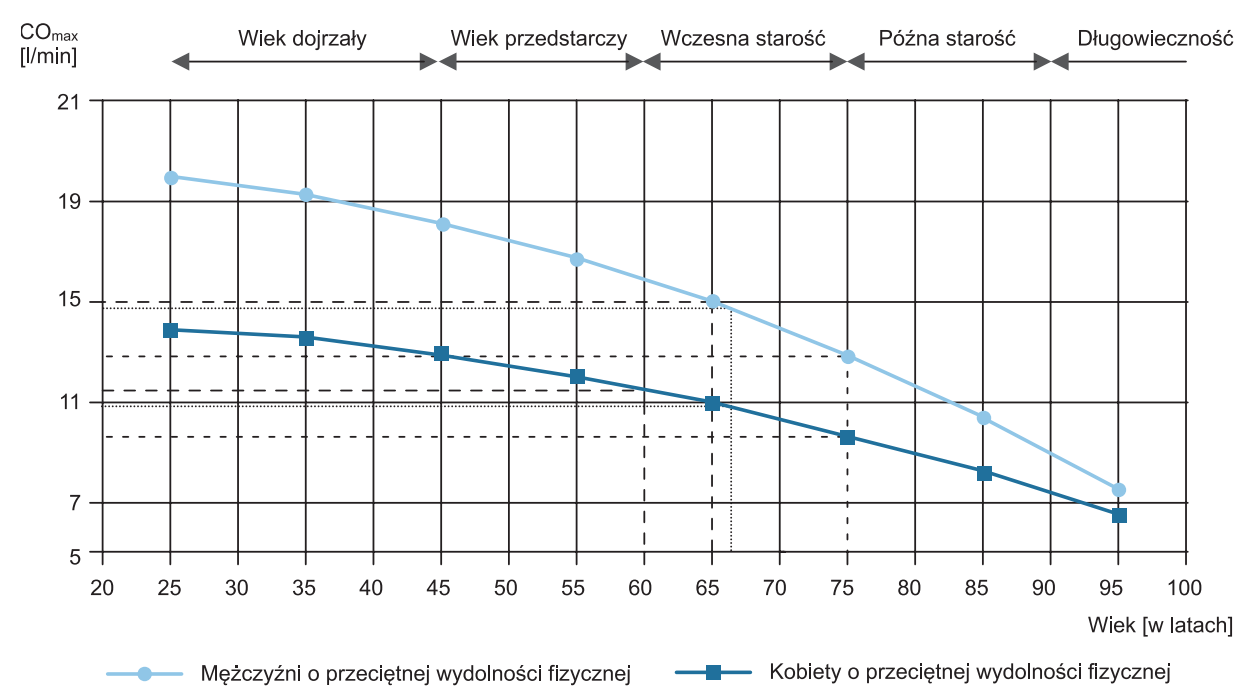

Ryc. 4. Zmiany $\mathrm{CO}_{\max }$ u mężczyzn i u kobiet o przeciętnej wydolności fizycznej przy przejściu od młodości do wieku starszego, wraz z zaznaczonymi wartościami $\mathrm{CO}_{\max }$ podczas przejścia na emeryturę.

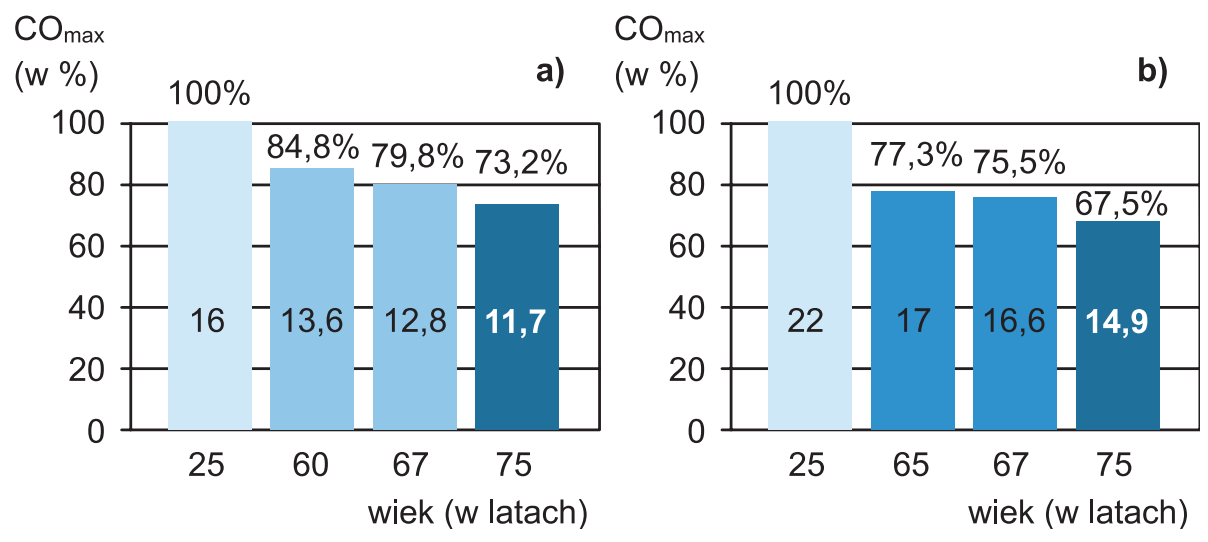

$\mathrm{CO}_{\max }$

Ryc. 5. Maksymalne parametry $\mathrm{CO}_{\max }$ podane w wartościach bezwzględnych i w procentach w stosunku do wartości wieku 25 lat (która wynosi 100\%), podczas przejścia na emeryturę:

a) kobiet w wieku 60 i 67 lat, b) mężczyzn w wieku 65 i 67 lat, oraz dla wieku 75 lat, który rozpoczyna późną starość. 


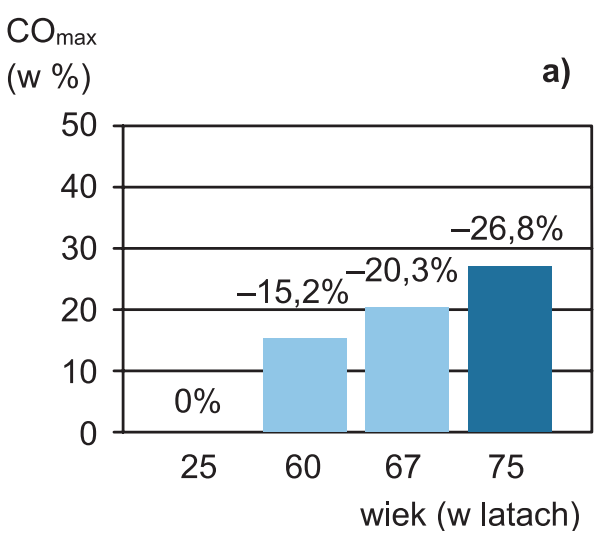

$\mathrm{CO}_{\max }$

a) $(\mathrm{w} \%)$

b)

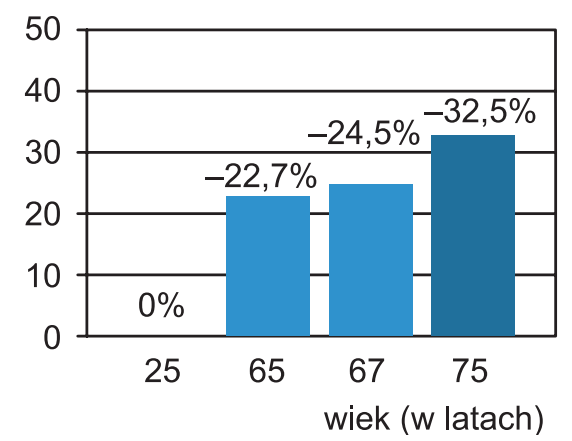

Ryc. 6. Ubytki parametrów $\mathrm{CO}_{\max }$ podane w procentach w stosunku do wartości, która wynosi 0\% w wieku 25 lat, podczas przejścia na emeryturę: a) kobiet w wieku 60 i 67 lat,

b) mężczyzn w wieku 65 i 67 lat, oraz dla wieku 75 lat, który rozpoczyna późną starość.

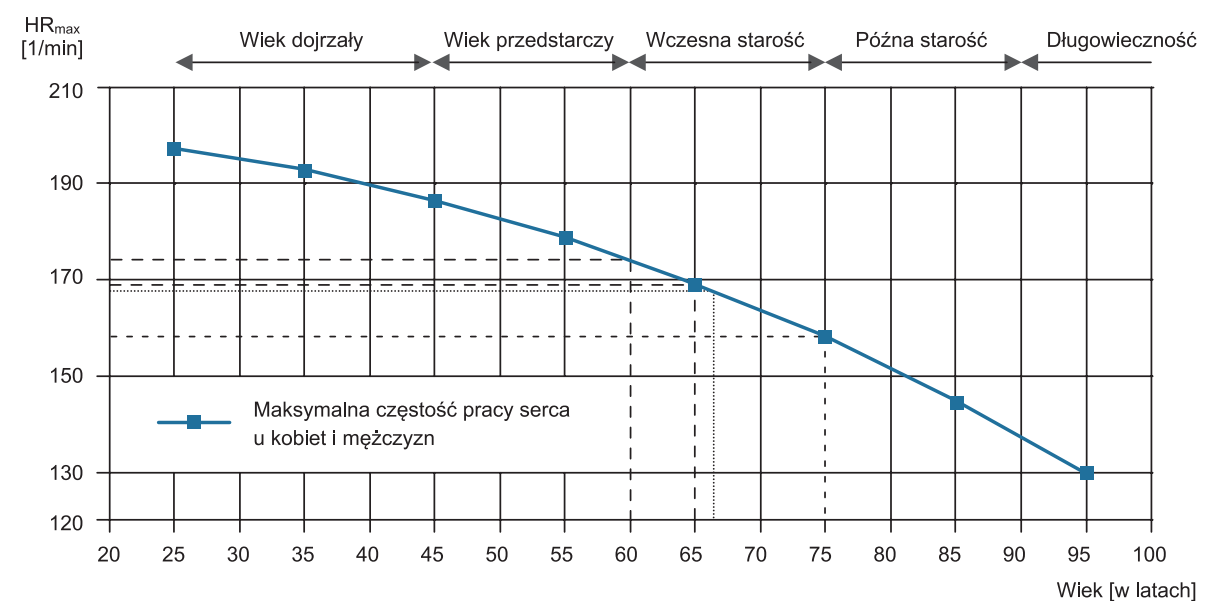

Ryc. 7. Zmiany $\mathrm{HR}_{\max }$ u mężczyzn i u kobiet o przeciętnej wydolności fizycznej zachodzą tak samo przy przejściu od młodosci do wieku starszego, wraz z zaznaczonymi wartościami $\mathrm{HR}_{\max }$ podczas przejścia na emeryturę. 


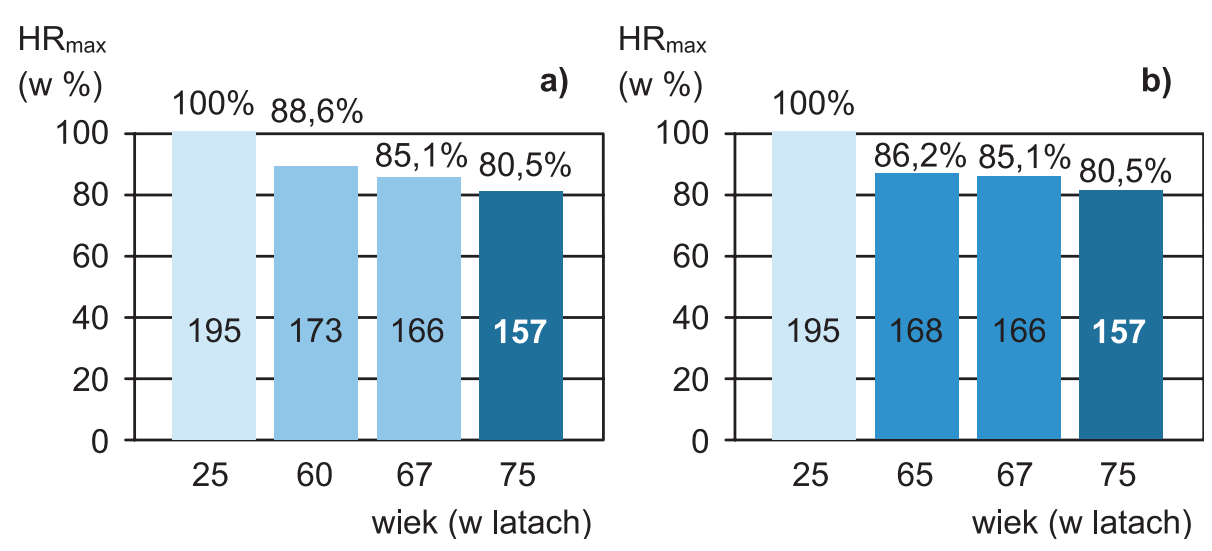

Ryc. 8. Maksymalne parametry HRmax podane w wartościach bezwzględnych i w procentach w stosunku do wartości wieku 25 lat (która wynosi 100\%), podczas przejścia na emeryturę:

a) kobiet w wieku 60 i 67 lat, b) mężczyzn w wieku 65 i 67 lat, oraz dla wieku 75 lat, który rozpoczyna późną starość.

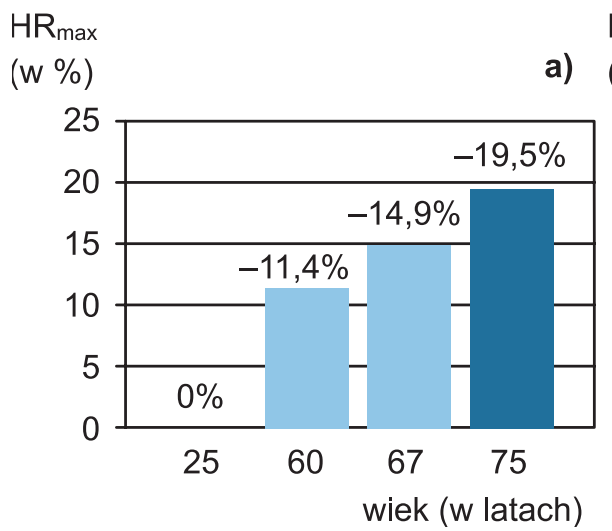

$\mathrm{HR}_{\max }$

a) $(\mathrm{w} \%)$

b)

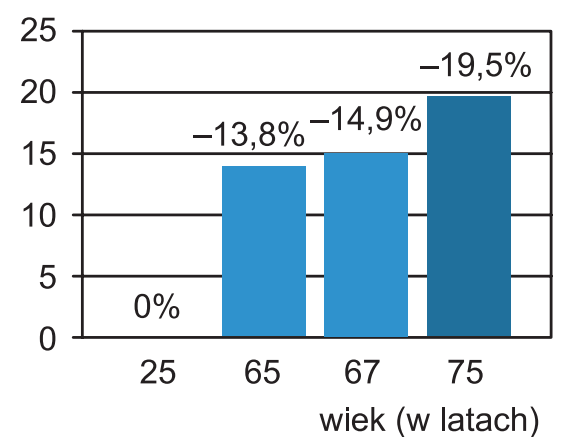

Ryc. 9. Ubytki parametrów $\mathrm{HR}_{\max }$ podane w procentach w stosunku do wartości, która wynosi 0\% w wieku 25 lat, podczas przejścia na emeryturę: a) kobiet w wieku 60 i 67 lat,

b) mężczyzn w wieku 65 i 67 lat, oraz dla wieku 75 lat, który rozpoczyna późną starość. 


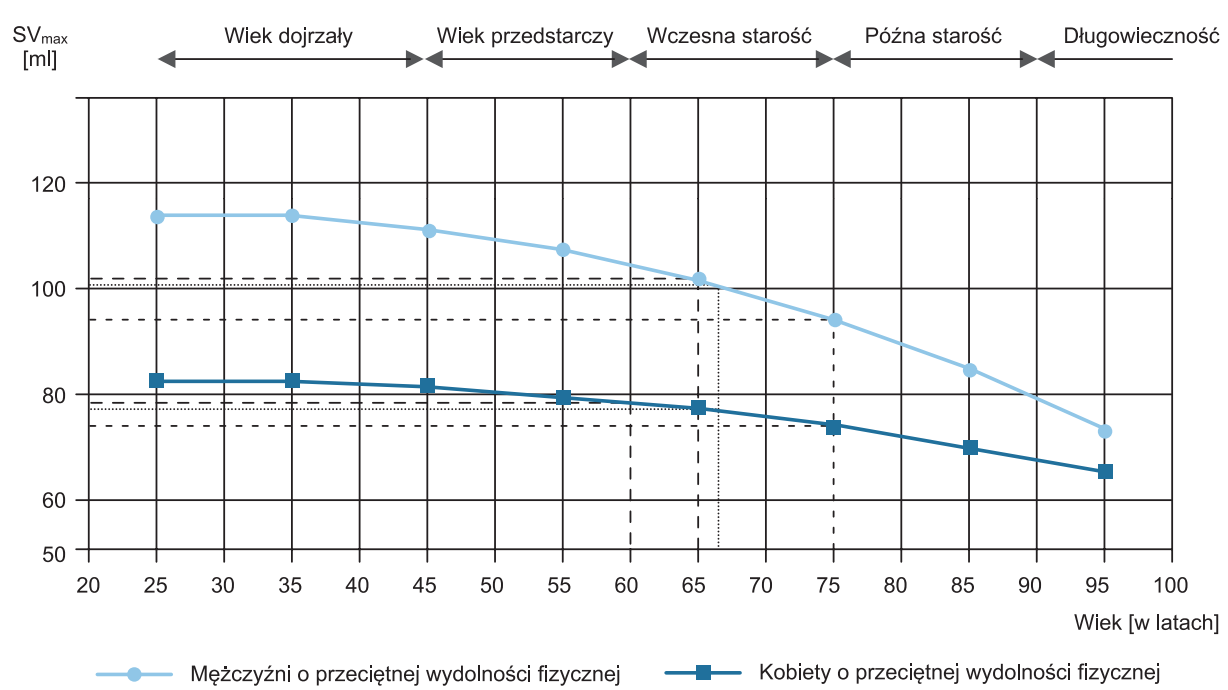

Ryc. 10. Zmiany $S_{\text {max }}$ u mężczyzn i u kobiet o przeciętnej wydolności fizycznej przy przejściu od młodosci do wieku starszego, wraz z zaznaczonymi wartościami SV ${ }_{\max }$ podczas przejścia na emeryturę.

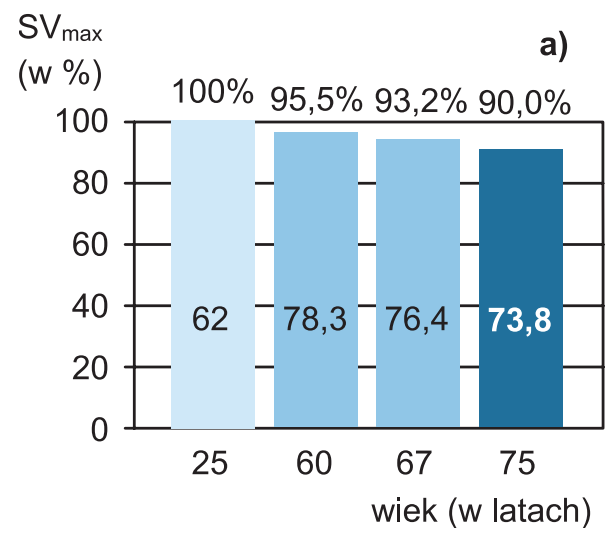

$S V_{\max }$

b) (w \%) $100 \% 89,4 \%$

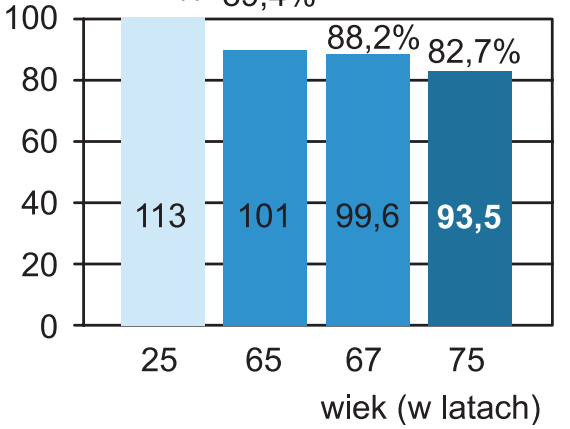

Ryc. 11. Maksymalne parametry $\mathrm{SV}_{\text {max }}$ podane $w$ wartościach bezwzględnych i w procentach w stosunku do wartości wieku 25 lat (która wynosi 100\%), podczas przejścia na emeryturę:

a) kobiet w wieku 60 i 67 lat, b) mężczyzn w wieku 65 i 67 lat, oraz dla wieku 75 lat, który rozpoczyna późną starość. 


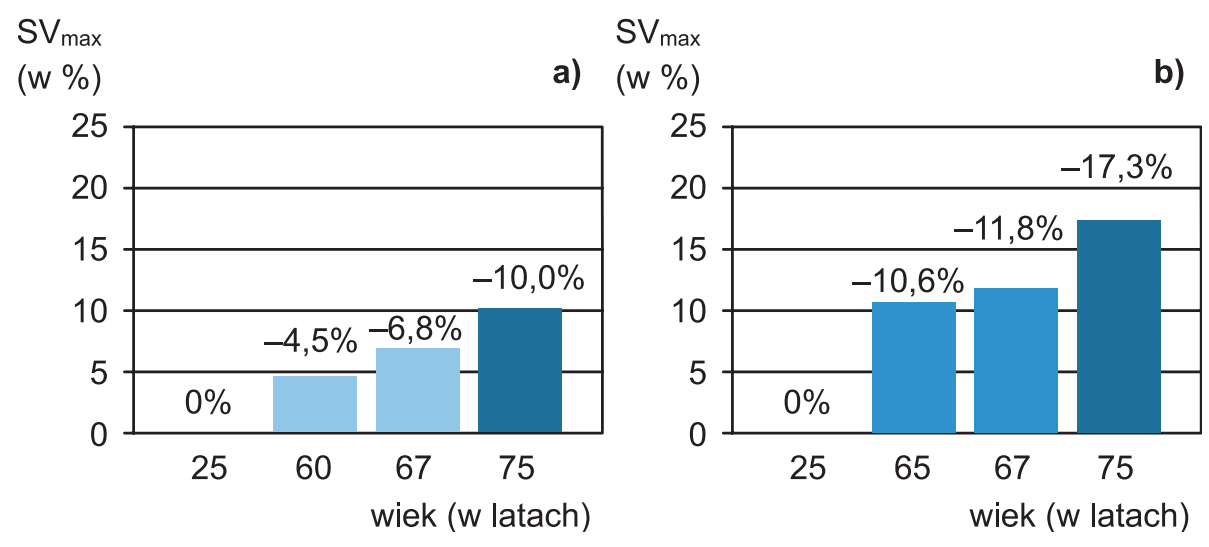

Ryc. 12. Ubytki parametrów $S V_{\text {max }}$ podane w procentach w stosunku do wartości, która wynosi 0\% w wieku 25 lat, podczas przejścia na emeryturę: a) kobiet w wieku 60 i 67 lat, b) mężczyzn w wieku 65 i 67 lat, oraz dla wieku 75 lat, który rozpoczyna późną starość.

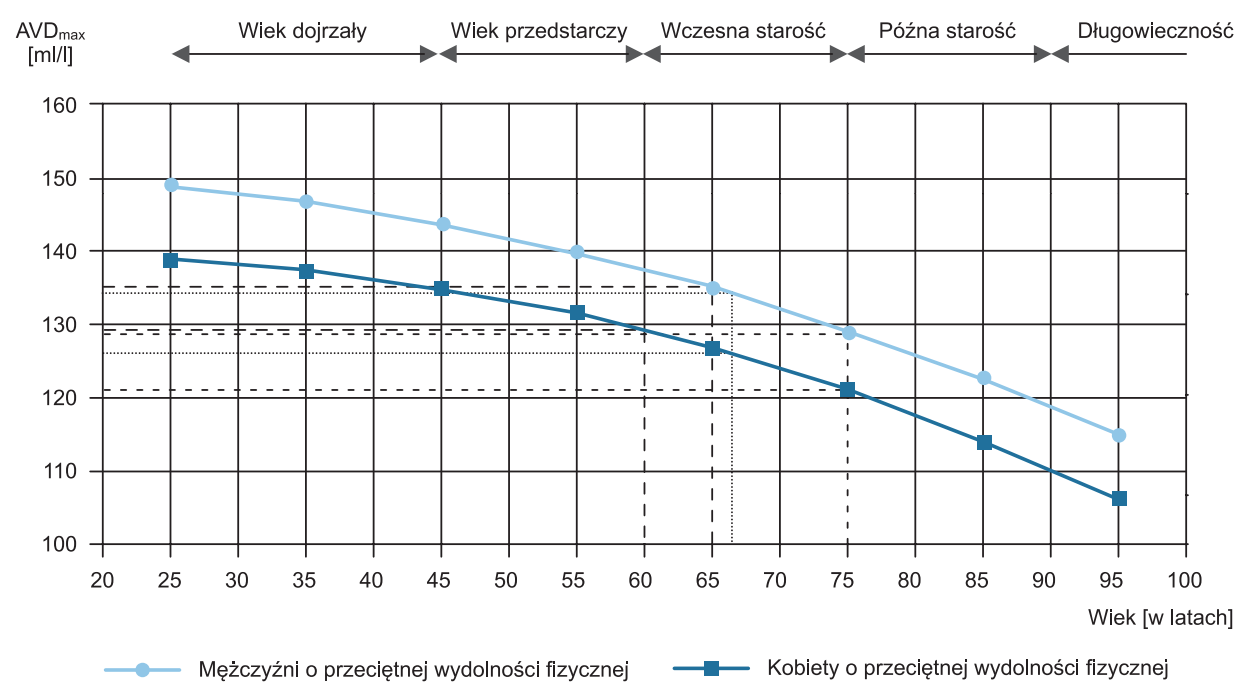

Ryc. 13. Zmiany $A V D_{\text {max }}$ u mężczyzn i u kobiet o przeciętnej wydolności fizycznej przy przejściu od młodosci do wieku starszego, wraz z zaznaczonymi wartościami AVD ${ }_{\max }$ podczas przejścia na emeryturę. 


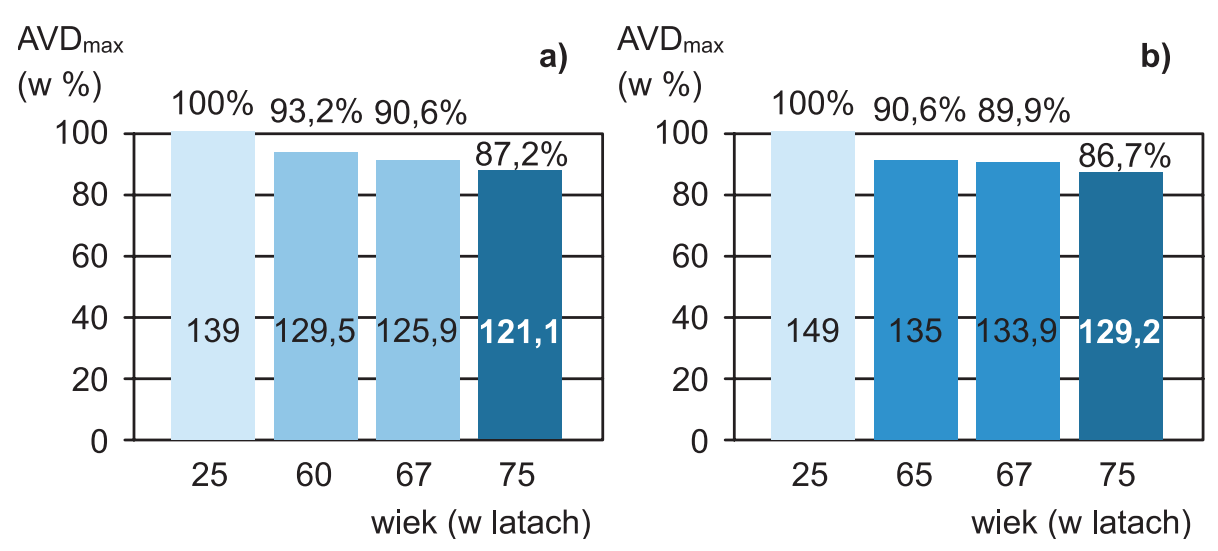

Ryc. 14. Maksymalne parametry $A V D_{\text {max }}$ podane w wartościach bezwzględnych i w procentach w stosunku do wartości wieku 25 lat (która wynosi 100\%), podczas przejścia na emeryturę:

a) kobiet w wieku 60 i 67 lat, b) mężczyzn w wieku 65 i 67 lat, oraz dla wieku 75 lat, który rozpoczyna późną starość.

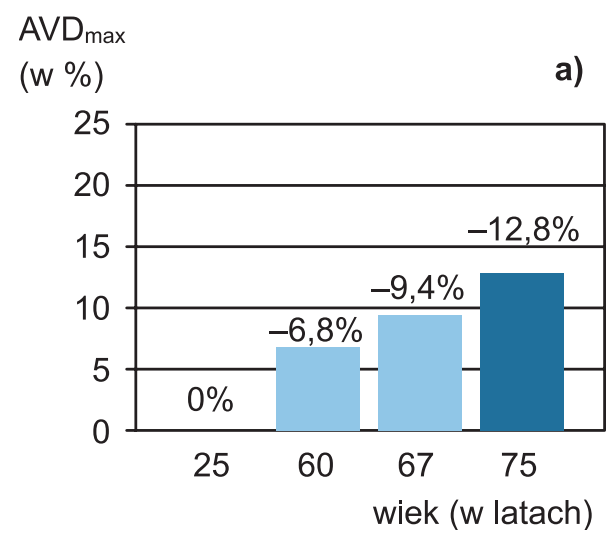

AVD $\max$

a) $(\mathrm{w} \%)$

b)

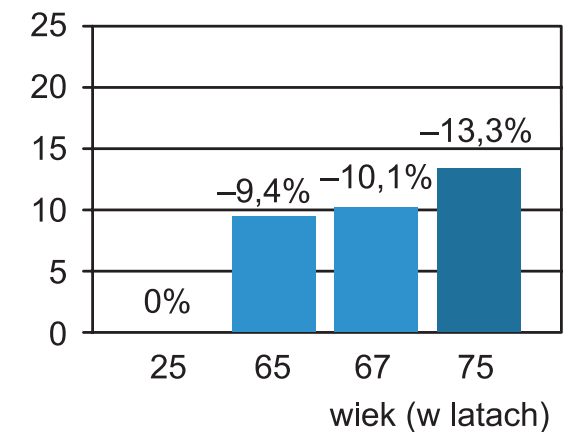

Ryc. 15. Ubytki parametrów $A V D_{\max }$ podane w procentach w stosunku do wartości, która wynosi 0\% w wieku 25 lat, podczas przejścia na emeryturę: a) kobiet w wieku 60 i 67 lat,

b) mężczyzn w wieku 65 i 67 lat, oraz dla wieku 75 lat, który rozpoczyna późną starość. 


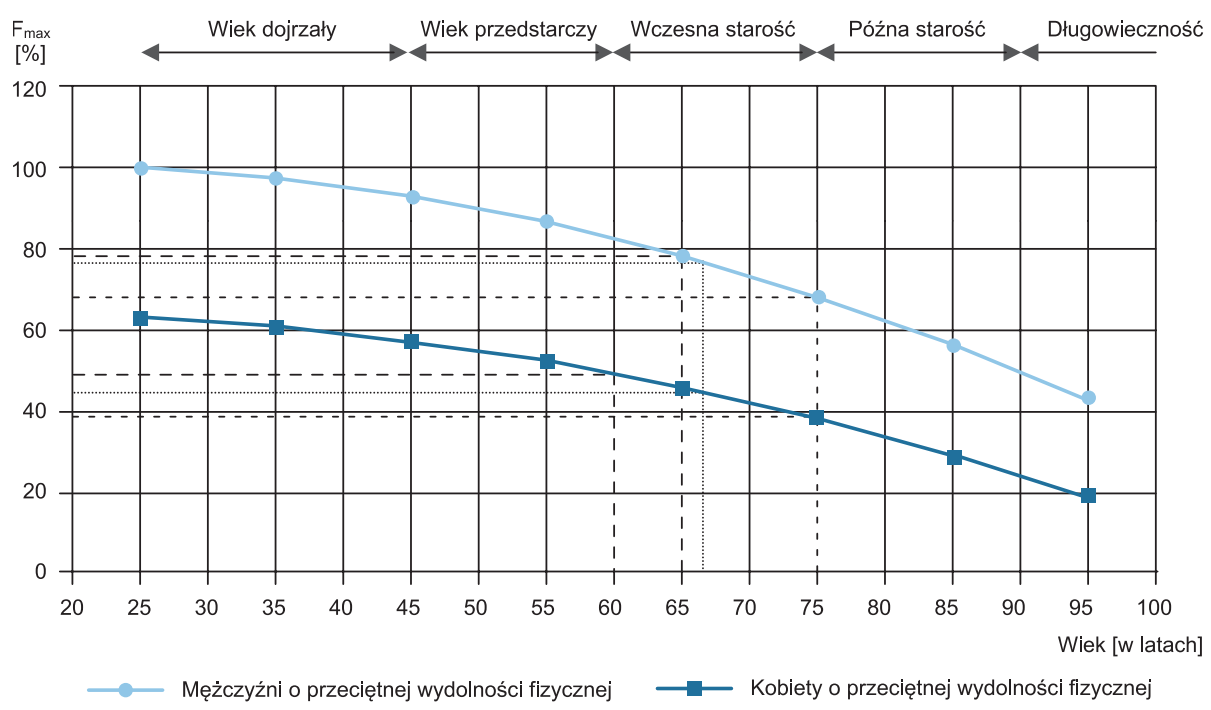

Ryc. 16. Zmiany maksymalnej siły mięśniowej mężczyzn i kobiet przy przejściu od młodości do wieku starszego, wraz z zaznaczonymi wartościami $F_{\max }$ podczas przejścia na emeryturę.

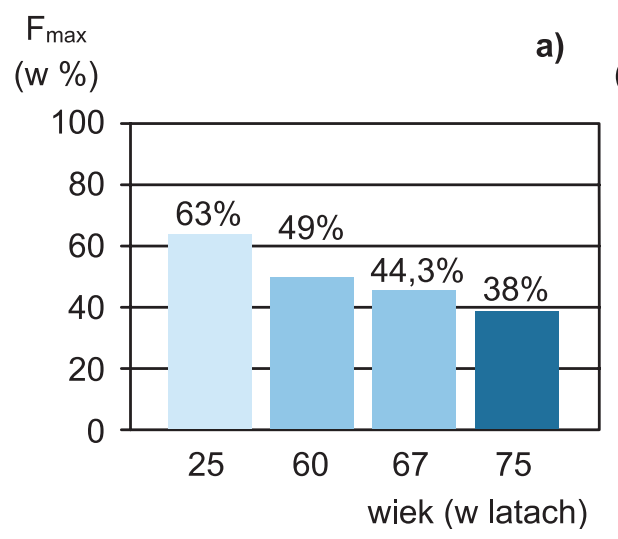
$\mathrm{F}_{\max }$

b)

Ryc. 17. Maksymalne parametry $F_{\max }$ podane w procentach w stosunku do wartości wieku 25 lat u mężczyzn (która wynosi 100\%), podczas przejścia na emeryturę: a) kobiet w wieku 60 i 67 lat, b) mężczyzn w wieku 65 i 67 lat, oraz dla wieku 75 lat, który rozpoczyna późną starość. 


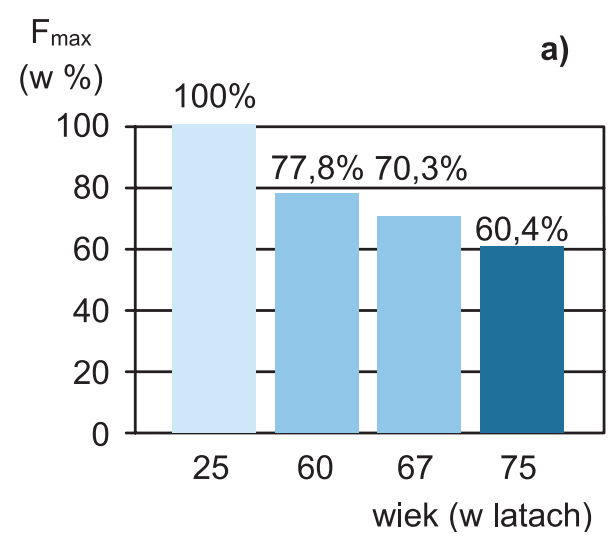

$$
\begin{gathered}
F_{\max } \\
(\mathrm{W} \%)
\end{gathered}
$$

b)

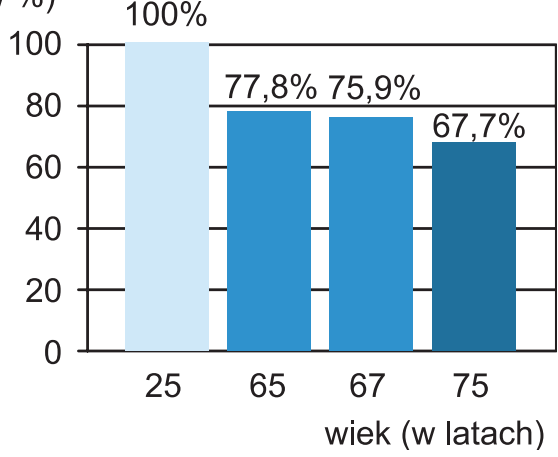

Ryc. 18. Maksymalne parametry Fmax podane w procentach w stosunku do wartości wieku 25 lat (która wynosi 100\%), podczas przejścia na emeryturę: a) kobiet w wieku 60 i 67 lat,

b) mężczyzn w wieku 65 i 67 lat, oraz dla wieku 75 lat, który rozpoczyna późną starość.

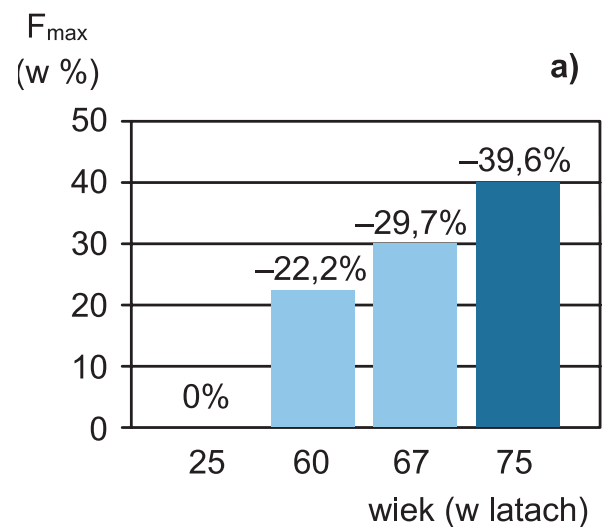

$F_{\max }$

a) $(w \%)$

b)

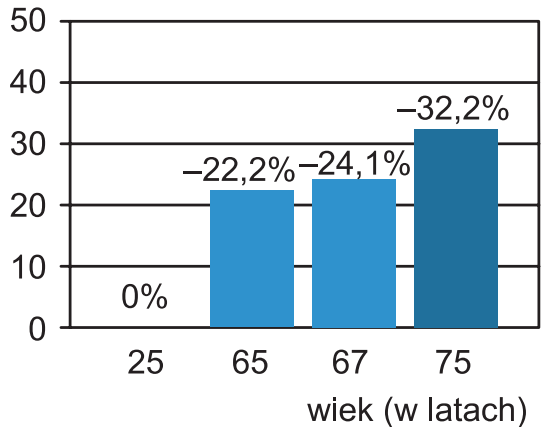

Ryc. 19. Ubytki parametrów $F_{\max }$ podane w procentach w stosunku do wartości, która wynosi

0\% w wieku 25 lat, podczas przejścia na emeryturę: a) kobiet w wieku 60 i 67 lat,

b) mężczyzn w wieku 65 i 67 lat, oraz dla wieku 75 lat, który rozpoczyna późną starość. 
Tabela 1. Ubytki maksymalnych parametrów fizjologicznych kobiet i mężczyzn podczas przejścia na emeryturę

\begin{tabular}{|c|c|c|c|c|c|c|c|}
\hline \multirow{3}{*}{ parametry } & \multicolumn{3}{|c|}{ kobiety } & & \multicolumn{3}{|c|}{ mężczyźni } \\
\hline & \multicolumn{3}{|c|}{ wiek } & & \multicolumn{3}{|c|}{ wiek } \\
\hline & 60 & 67 & 75 & parametry & 65 & 67 & 75 \\
\hline 1) $F \max [\%]$ & $-22,2$ & $-29,7$ & $-39,6$ & 1) $\mathrm{Vo}_{2} \max [\%]$ & $-30,3$ & $-32,7$ & $-43,2$ \\
\hline 2) $\mathrm{Vo}_{2} \max [\%]$ & $-20,6$ & $-27,9$ & $-37,6$ & 2) $\mathrm{CO} \max [\%]$ & $-22,7$ & $-24,5$ & $-32,5$ \\
\hline 3) $\mathrm{CO} \max [\%]$ & $-15,2$ & $-20,3$ & $-26,8$ & 3) $F \max [\%]$ & $-22,2$ & $-24,1$ & $-32,2$ \\
\hline 4) HR max [\%] & $-11,4$ & $-14,9$ & $-19,5$ & 4) HR max [\%] & $-13,8$ & $-14,9$ & $-19,5$ \\
\hline 5) AVD max [\%] & $-6,8$ & $-9,4$ & $-12,8$ & 5) SV max [\%] & $-10,6$ & $-11,8$ & $-17,3$ \\
\hline 6) SV max [\%] & $-4,5$ & $-6,8$ & $-10,0$ & 6) AVD max [\%] & $-9,4$ & $-10,1$ & $-13,3$ \\
\hline $\begin{array}{l}\text { średni ubytek } \\
\text { parametrów [\%] }\end{array}$ & $-13,45$ & $-18,15$ & $-24,4$ & $\begin{array}{l}\text { średni ubytek } \\
\text { parametrów [\%] }\end{array}$ & $-18,2$ & $-19,7$ & $-26,35$ \\
\hline
\end{tabular}

\section{Omówienie}

Wyznaczone maksymalne parametry fizjologiczne kobiet i mężczyzn podczas przejścia na emeryturę są obiektywną, ilościową oceną stanu zdrowia badanych osób.

Dla zrealizowania celu pracy należało wykonać badania poprzeczne w stosunku do maksymalnych parametrów fizjologicznych kobiet i mężczyzn podczas przejścia od młodości do wieku starszego ${ }^{10}$. Badania te przeprowadzono dla osób o przeciętnej wydolności fizycznej, które starzeją się fizjologicznie (typ starzenia zdrowy i zwykły $)^{11}$. Dla kobiet badania poprzeczne dokonano dla wieku: 60, 67 i 75 lat, natomiast dla mężczyzn dla wieku 65, 67 i 75 lat. We wszystkich przypadkach wyznaczono następujące maksymalne parametry fizjologiczne:

1) pułap tlenowy (maksymalny minutowy pobór tlenu, $\mathrm{Vo}_{2 \max }$ ),

2) maksymalną pojemność minutową serca $\left(\mathrm{CO}_{\max }\right)$,

3) maksymalną częstość pracy serca $\left(\mathrm{HR}_{\max }\right)$,

4) maksymalną objętość wyrzutową serca ( $\left.\mathrm{SV}_{\max }\right)$,

5) maksymalną różnicę tętniczo-żylną wysycenia krwi tlenem $\left(\mathrm{AVD}_{\max }\right)$,

6) maksymalną siłę mięśniową $\left(\mathrm{F}_{\max }\right)$.

Wartości tych parametrów przedstawiono w postaci wartości bezwzględnych i względnych (\%), natomiast ubytki tych parametrów przedstawiono w stosunku do parametrów w wieku 25 lat, gdy są one optymalne. Dla dokonania pełniejszej oceny badanych maksymalnych parametrów fizjologicznych podczas przejścia na emeryturę

10 Zob.: J. Szubert i in., Innowacyjna metoda wyznaczania maksymalnych parametrów fizjologicznych serca kobiet i mężczyzn podczas przejścia od młodości do wieku starszego, II Konferencja Naukowa Profesjonalizacja Kreatywności: Kreatywne Myślenie-Kreatywne Działanie, Lublin 2017.

11 Zob.: A. Marchewka, dz. cyt.. 
porównano je także z maksymalnymi parametrami fizjologicznymi kobiet i mężczyzn w wieku 75 lat, tzn. kiedy człowiek wchodzi w okres późnej starości. Poza tym, z wyników przedstawionych tabelarycznie wynika, że największy ubytek w przypadku kobiet wykazuje maksymalna siła mięśni $\left(\mathrm{F}_{\max }\right)$, a najmniejszy objętość wyrzutowa serca $\left(\mathrm{SV}_{\max }\right)$. Średnie ubytki wszystkich badanych parametrów u kobiet wynoszą: dla 60 lat $\rightarrow-13,45 \%$, dla 67 lat $\rightarrow-18,15 \%$, dla 75 lat $\rightarrow-24,4 \%$. W przypadku mężczyzn największy ubytek wykazuje pułap tlenowy $\left(\mathrm{Vo}_{2 \max }\right)$, a najmniejszy różnica tętniczo-żylna wysycenia krwi tlenem $\left(\mathrm{AVD}_{\max }\right)$. Średnie ubytki wszystkich badanych parametrów u mężczyzn wynoszą: dla 65 lat $\rightarrow-18,2 \%$, dla 67 lat $\rightarrow-19,7 \%$, dla 75 lat $\rightarrow-26,35 \%$. Według autorów pracy, średnie ubytki maksymalnych parametrów fizjologicznych:

1) do $15 \%$ należy przyjąć jako małe,

2) do $20 \%$ należy przyjąć jako średnie,

3) do $25 \%$ należy przyjąć jako duże,

4) powyżej 25\% należy przyjąć jako bardzo duże.

Zgodnie z tym ubytki średnich parametrów fizjologicznych:

1) dla kobiet w wieku 60 lat należy traktować jako małe $(-13,45 \%)$, w wieku 67 lat - jako średnie $(-18,15 \%)$, natomiast w wieku 75 lat jako duże $(-24,4 \%)$;

2) dla mężczyzn w wieku 65 i 67 lat należy traktować jako średnie (odpowiednio $-18,2 \%$ i -19,7\%), natomiast w wieku 75 lat jako bardzo duże (-26,35\%).

Powszechnie wiadomo, że praca jest źródłem dobrobytu. Należy więc wykorzystywać wszelkie sposoby, aby zwiększyć poziom zatrudnienia w Polsce. Jest ono obecnie bardzo niskie (współczynnik zatrudnienia najniższy w UE), zwłaszcza wśród osób w wieku przedemerytalnym. Jest to spowodowane głównie ogromną skalą wcześniejszych emerytur, jak również masowym przechodzeniem na emerytury od razu w momencie nabycia uprawnień emerytalnych. Zwiększenie zatrudnienia osób w wieku powyżej 50 roku życia jest jednym z głównych wyzwań stojących przez Polską ${ }^{12}$.

Chęć ograniczenia dezaktywizacji zawodowej osób w wieku okołoemerytalnym w dużej mierze oznacza potrzebę ograniczenia dezaktywizacji emerytalnej, bo decyzje o przejściu na emeryturę i o zaprzestaniu pracy są silnie skorelowane. Ograniczenie dezaktywizacji emerytalnej potrzebne jest też dlatego, że jeśli następuje w sposób masowy i jest zbyt wczesna, stanowi obciążenie dla finansów publicznych, bardzo trudne do udźwignięcia ze względu na starzenie się społeczeństwa. Chodzi zatem zarówno o to, żeby jak najpóźniej przechodzić na emeryturę oraz najpóźniej zaprzestawać pracy zawodowej w ogóle ${ }^{13}$.

12 Zob.: J. Hryniewicz, Uwarunkowania zmiany ustawowego wieku emerytalnego w Polsce w 2012 roku, Warszawa 2012; Lex. pl, dz. cyt.; G. Marciniak, dz. cyt.; D. Niewiedzał, Psychologiczne aspekty starzenia się, ROPS, Zielona Góra 2011; W. Otto, M. Bitner, dz. cyt.; J. Zalewska, dz. cyt.

13 Zob.: Z. Bartuś, Emerytura bez dorabiania, „Dziennik Łódzki”, 2016; F. Chybalski, System emerytalny: definicje, cele, klasyfikacje, Warszawa 2016; Konfederacja Lewiatan, dz. cyt.; P. Kubicki, Oswoić starość czy eutanazję?, Instytut Obywatelski, Warszawa 2012; K. Michalska, Młodzi emeryci zabieraja prace młodym, Analiza Forum Obywatelskiego Rozwoju Nr 07/2012 z 12.04.2012; Raport $\mathrm{z}$ badań, dz. cyt. 
W celu ograniczenia dezaktywizacji emerytalnej konieczne są zmiany w systemie emerytalnym i/lub prawie pracy, polegające na ${ }^{14}$ :

a) ograniczeniu możliwości wczesnej dezaktywizacji (np. poprzez podniesienie minimalnego wieku emerytalnego);

b) ograniczeniu zachęt do przechodzenia na emeryturę osób, które jeszcze mogą pracować (o ile to możliwe, należy je zastąpić zachętami do nieprzechodzenia na emeryturę);

c) utrudnieniu pracodawcom pozbywania się starszych pracowników na koszt reszty społeczeństwa tak, jak to ma miejsce w przypadku wcześniejszych emerytur (np. poprzez odpowiednie rozwiązania fiskalne, zmniejszające opodatkowanie pracy starszych osób).

W celu ograniczenia dezaktywizacji zawodowej należy stworzyć mechanizmy pomocy osobom w wieku 50+, nakierowane na podniesienie i przedłużenie ich zatrudnienia.

\section{Wnioski}

1. Znajomość wykresów maksymalnych parametrów fizjologicznych serca i mięśni w funkcji wieku, poprzez badania poprzeczne pozwala wyznaczyć maksymalne parametry fizjologiczne serca i mięśni kobiet oraz mężczyzn podczas przejścia na emeryturę.

2. Im późniejszy wiek przejścia na emeryturę, tym maksymalne parametry serca i mięśni, tak u kobiet, jak i u mężczyzn, przyjmują coraz niższe wartości.

3. W przypadku kobiet największy ubytek wartości parametrów fizjologicznych przyjmuje maksymalna siła mięśni $\left(\mathrm{F}_{\max }\right)$, a najmniejszy - objętość wyrzutowa serca (SV max).

4. W przypadku mężczyzn największy ubytek wartości parametrów fizjologicznych przyjmuje pułap tlenowy $\left(\mathrm{Vo}_{2 \max }\right)$, a najmniejszy - różnica tętniczo-żylna wysycenia krwi tlenem $\left(\mathrm{AVD}_{\max }\right)$.

${ }^{14}$ Zob.: A. Duda, dz. cyt.; Dziennik Gazeta Prawna, Opłaca się opóźnić przejście na emeryturę nawet o miesiac. Rynek Seniora, Warszawa 03.02.2016; B. Godusławski, Jednorazowy bonus w wysokości 10 000zł osobom, które ni przejdą na emeryturę, zaraz po osiagnięciu wieku emerytalnego, „Puls Biznesu” 15.03.2017; C. Kochalski, Przejście na emeryturę to prawo, nie obowiązek, „Ubezpieczenia Emerytalne i Rentowe”, 31.05.2017; Ł. Kozłowski, 10 000+ zamiast przejścia na emeryturę? Trzeba zachęcać Polaków do pozostawania dłużej na rynku pracy, Polskie Radio 24, 16.03.2017; J. Mordasiewicz, 10 tys. zł dla emeryta za późniejsze przejście na emeryturę, Konfederacja Lewiatan, Warszawa 16.03.2017; MRPiP, Przejście o rok później na emeryturę podwyższy jej wartość o 8 proc., wSensie. pl, Warszawa 09.04.2017; J. Plak, Etapy przechodzenia na emeryture - charakterystyka i wyzwania, Targi seniora, Kraków 07.06.2017; E. Rafalska, Opłaca się później przejść na emeryturę, Dziennik.pl, Warszawa 19.04.2017; taż, Przejście na emeryturę jest naszą decyzją i wyborem, NSZZ „Solidarność”, Kraków 18.05.2017. 
5. Średnie ubytki parametrów fizjologicznych dla kobiet w wieku 60 lat należy traktować jako małe $(-13,45 \%)$, w wieku 67 lat - jako średnie $(-18,15 \%)$, natomiast w wieku 75 lat - jako duże $(-24,4 \%)$.

6. Średnie ubytki parametrów fizjologicznych dla mężczyzn w wieku 65 i 67 lat należy traktować jako średnie (odpowiednio -18,2\% i-19,7\%), natomiast w wieku 75 lat jako bardzo duże (-26,35\%).

7. Dzięki kreatywnemu działaniu autorów po raz pierwszy wyznaczono maksymalne parametry fizjologiczne serca i mięśni kobiet oraz mężczyzn podczas przejścia na emeryturę, które stanowią dokładną, obiektywną, ilościową ocenę stanu zdrowia osób przechodzących na emeryturę

\section{Bibliografia}

Bartuś Z., Emerytura bez dorabiania, „Dziennik Łódzki”, 2016.

Chybalski F., System emerytalny: definicje, cele, klasyfikacje, Warszawa 2016.

Conn P. M., Handbook of models for human aging, Elsevier, New York 2006.

Correia L. C. L., Lakatta E.G., O`connor F. C., Becker L. C., Clulow J., Townsend S., Gerstenblith G., Fleg J. L., Attenuated cardiovascular reserve during prolonged submaximal cycle exercise in healthy older subjects, JACC, $\mathrm{nr} 40(7) / 2002$, s. 1290-1297.

Daskalski A., Handbook of research on systems Biology applications in medicine. Medical Information Science Reference, New York 2009.

Dill D. B., Horvath S. M., Craig F. N., Responses to exercise as related to age, J Appl Physiol, nr 12(2)/1958, s. 195-196.

Duda A., Powinniśmy wybierać moment przejścia na emeryture, AJP. 11.05.2017. Warszawa.

Dziennik Gazeta Prawna, Opłaca się opóźnić przejście na emeryturę nawet o miesiąc. Rynek Seniora, Warszawa 03.02.2016.

Era P., Rantanen T., Changes in physical capacity and sensory/psychomotor functions from 75 to 80 years of age and from 80 to 85 years of age - a longitudinal study, Scand J Med Soc Supl, nr 53/1997, s. 25-43.

Ferraro K. F., Kelley-Moore J. A., A half century of longitudinal methods in social gerontology: evidence of change in the journal, "The Journals of Gerontology: Series B”, $\operatorname{nr}$ 58(5)/2003, s. 264-270.

Fleg J. L., Morrell C. H., Bos A. G., Brant L. J., Talbot L. A., Wright J. G., Lakatta E. G., Accelerated longitudinal decline of aerobic in healthy older adults, "Circulation", nr 112(5)/2005, s. 624-682.

Fleg J. L., O 'connor F., Gestenblith G., Becker L. C., Clulow J., Schulman S. P., Lakatta E. G., Impact of age on the cardiovascular response to dynamic upright exercise in healthy men and women, J Appl Physiol, nr 78(3)/1995, s. 890-900. 
Godusławski B., Jednorazowy bonus w wysokości 10 000zł osobom, które ni przejda na emeryture, zaraz po osiagnięciu wieku emerytalnego, „Puls Biznesu” 15.03.2017.

Guyton A., Hall J., Textbook of medical physiology, W. B. Saunders, Philadelphia 2005.

Hollenberg M., Yang J., Haight T. J., Tager J. B., Longitudinal changes in aerobic capacity: implications for concepts of aging, J Gerontol A Biol Sci Med Sci, nr 61(8)/2006, s. 851-858.

Houghton D., Jones T. W., Cassidy S., Sierro M., Mac Gowan G. A., Trenell M. J., Jakovljeric D. G., The effect of age on the relationship between cardiac and vascular, Mech Ageing Dev, nr 153/2015, s. 1-6

Hryniewicz J., Uwarunkowania zmiany ustawowego wieku emerytalnego w Polsce w 2012 roku, Warszawa 2012.

Jackson A. S., Janssen J., Sui X., Church T. S., Blair S. N., Longitudinal changes in body composition associated with healthy ageing: men, aged 20-96 years, British Journal of Nutrition, nr 107(7)/2012, s. 1085-1091.

Kaess B. M., Rong J., Larson M. G., Hamburg N. M., Vita J. A., Levy D., Benjamin E. J., Vasan R. S., Mitchell G. F., Aortic stiffness, blood pressure progression and incident hypertension, JAMA., nr 308(9)/2012, s. 875-881.

Kenney W. L., Wilmore J. H., Costill D. L., Physiology of sport and exercise, Human Kinetics, Champaign 2015.

Kochalski C., Przejście na emeryturę to prawo, nie obowiązek, „Ubezpieczenia Emerytalne i Rentowe", 31.05.2017.

Konfederacja Lewiatan: Informacja prasowa. 8.12.2016, Warszawa

Kozłowski Ł., 10 000+ zamiast przejścia na emeryturę? Trzeba zachęcać Polaków do pozostawania dłużej na rynku pracy, Polskie Radio 24, 16.03.2017.

Kozłowski S., Nazar K., Wprowadzenie do fizjologii klinicznej, PZWL, Warszawa 1999.

Kubicki P., Oswoić starość czy eutanazję?, Instytut Obywatelski, Warszawa 2012.

Laskowska-Szcześniak M., Kozak-Szkopek E., Uwarunkowania pomyślnego starzenia, Forum Medycyny Rodzinnej, nr 7(6)/2013, s. 287-294.

Lex.pl: Wyrok z dnia 16 lipca 2010 r. Sąd Rejonowy we Wrocławiu IV JP 300/2009 oraz wyrok Okręgowego Sądu Administracyjnego: OSA 2012/4/112-134.

Lindeman R. D., Tobin J., Shock N.W., Longitudinal studies on the rate of decline in renal function with age, J Am Geriatr Soc, nr 33(4)/1985, s. 278-285.

Marchewka A., Dąbrowski Z., Żołądź J. A., Fizjologia starzenia się, PWN, Warszawa 2013.

Marciniak G., Wyzwania polityki ludnościowej wobec prognoz demograficznych dla Polski i Europy, Główny Urząd Statystyczny, Wrocław 2015.

Michalska K., Młodzi emeryci zabieraja prace młodym, Analiza Forum Obywatelskiego Rozwoju Nr 07/2012 z 12.04.2012.

Mordasiewicz J., 10 tys. zł dla emeryta za późniejsze przejście na emeryturę, Konfederacja Lewiatan, Warszawa 16.03.2017. 
MRPiP, Przejście o rok później na emeryturę podwyższy jej wartość o 8 proc., wSensie. pl, Warszawa 09.04.2017.

Niewiedzał D., Psychologiczne aspekty starzenia się, ROPS, Zielona Góra 2011.

Otto W., Bitner M., Konsekwencje obniżenia wieku emerytalnego, Warszawa 2016.

Plak J., Etapy przechodzenia na emeryture - charakterystyka i wyzwania, Targi seniora, Kraków 07.06.2017.

Plowman S. A., Smith D. L., Exercise physiology, Lippincott Williams \& Wilkins, Philadelphia 2014.

Pollock R. D., Carter S., Velloso C. P., Duggal N. A., Lorel J. M., Lazarus N. R., Harridge S. D. R., An investigation into the relationship between age and physiological function in highly active older adults, J Physiol, 2015, 593 (3), s. 657-680.

Rafalska E., Opłaca się później przejść na emeryturę, Dziennik.pl, Warszawa 19.04.2017.

Rafalska E., Przejście na emeryturę jest naszą decyzją i wyborem, NSZZ „Solidarność, Kraków 18.05.2017.

Raport z badań: Dezaktywacja osób w wieku około emerytalnym, Departament Analiz Ekonomicznych i Prognoz, Ministerstwo Pracy i Polityki Społecznej, Warszawa 2008.

Rogasta M., Textbook of clinical hemodynamics, Saunders Elsevier, Philadelphia 2008.

Sessions A., Engler A. J., Mechanical regulation of cardiac aging in model systems, "Circulation Research", nr 118(10)/2016, s. 1553-1562.

Sieck G. C., Physiology of aging, J Appl Physiol, nr 95 (4)/2003, s. 1333-1334.

Szubert J., Szubert S., Rydz S., Michałowska-Wieczorek I., Szymańska-Paszczuk A., Ziółkowski W., Wieczorek W., Szubert P., Innowacyjna metoda wyznaczania maksymalnych parametrów fizjologicznych serca kobiet i mężczyzn podczas przejścia od młodości do wieku starszego, II Konferencja Naukowa Profesjonalizacja Kreatywności: Kreatywne Myślenie-Kreatywne Działanie, Lublin 2017.

Taylor A. W., Johnson M. J., Physiology of exercise and healthy aging, Human Kinetics Champaign IL, New York 2008.

Zalewska J., Od emerytury do trzeciego wieku: starość w czasach nowożytnych, Warszawa 2011.

Żołądź J. A., Majerczak J., Wpływ starzenia się na wydolność fizyczna człowieka, [w:] Fizjologiczne procesy starzenia, red. J. Marchewka, J. A. Żołądź, Z. Dąbrowski, PWN, Warszawa 2011. 
Maximum physiological parameters of the heart and muscles of women and men during the process of retirement

Abstract: Ageing is a physiological process that manifests itself with age. It is characterized by the constant reduction of maximal physiological parameters and by lower levels of regeneration and adaptability. There are three types of ageing: healthy, normal and morbid. The first two types of ageing are classified as physiological ageing and include about $65 \%$ of men and women.

Such ageing is investigated by the authors of the paper in determining the maximum physiological parameters of the heart and muscles of women and men during their retirement. At present, people who reach retirement age and age physiologically are not infirm old people; and on the contrary, they usually function normally.

The purpose of the study is to determine the physiological parameters of the heart and muscles of women and men with average physical fitness at retirement age - 67 years old, as well as for 60 -year-old women and for men 65 years of age.

The determined maximum physiological parameters of the heart and muscles of women and men allow for accurate, objective and quantitative assessment of the health condition of those in the process of retirement.

Keywords: retirement process, maximum physiological parameters of heart and muscles.

\author{
About the authors: Dr Józef Szubert - academic teacher. \\ Dr Sławomir Szubert - academic teacher. \\ Dr Sylwia Rydz - Vice Rector of AHE, academic teacher. \\ Dr Izabella Michałowska-Wieczorek - academic teacher. \\ Mgr Alicja Szymańska-Paszczuk - academic teacher. \\ Dr prof. WSIU Włodzimierz Ziółkowski - Dean of the Department of Pedagogy \\ and Health Promotion. \\ Dr Wojciech Wieczorek - academic teacher. \\ Paweł Szubert - student of Lodz University of Technology.
}




\author{
Błażej Kmieciak* \\ Uniwersytet Medyczny w Łodzi \\ bkmieciak@o2.pl
}

\title{
Tajemnica psychiatryczna z perspektywy teoretycznych oraz praktycznych wyzwań: uwagi socjoetyczno-prawne ${ }^{1}$
}

\begin{abstract}
Streszczenie: Wizyta pacjenta u lekarza posiada szczególny charakter. Odnosi się ona do sytuacji, w której jedna z osób doświadcza określonego problemu. W trakcie wspomnianej wizyty bardzo często ujawniane są istotne informacje, które często dotyczą ważnych dla pacjenta spraw, które chce pozostawić on w tajemnicy. To właśnie dlatego - zarówno z perspektywy prawnej, jak i etycznej - unikalne znaczenie posiada instytucja tajemnicy lekarskiej. Szczególny charakter posiada w tym aspekcie tajemnica psychiatryczna. Psychiatra - w trakcie wykonywania swojej pracy - uzyskać może informacje, które świadczyć mogą o dokonaniu przez pacjenta przestępstwa. Jak się okazuje, specjalista ten zobowiązany jest w podobnej sytuacji do zachowania tajemnicy. Nie może on powiadomić o tym np. prokuratury lub policji. Czy to oznacza, że tajemnica psychiatryczna ma charakter absolutny? Czy są od niej jakieś wyjątki? Co powinien zrobić psychiatra, gdy jego pacjent nie dokonał, ale dopiero planuje popełnić konkretne przestępstwo? W artykule podjęta zostanie próba odpowiedzi na wspomniane pytania.
\end{abstract}

Słowa kluczowe: prawa pacjenta, ochrona zdrowia psychicznego, tajemnica psychiatryczna, przymusowe leczenie, opinia sądowa.

* Błażej Kmieciak - doktor nauk społecznych w zakresie socjologii prawa, bioetyk oraz pedagog specjalny. Adiunkt w Zakładzie Prawa Medycznego Uniwersytetu Medycznego w Łodzi, wykładowca prawa w Pracowni Pedagogiki Specjalnej Uniwersytetu Łódzkiego, były Rzecznik Praw Pacjenta Szpitala Psychiatrycznego. Autor publikacji z zakresu socjologii prawa, prawa medycznego oraz praw człowieka, w tym monografii książkowych: Prawa pacjenta i ich ochrona. Studium socjologiczne, Bioetyka, między prawem a pedagogika (razem z Mirosławem Kowalskim) oraz Prawa dziecka jako pacjenta.

${ }^{1}$ Artykuł został przygotowany w ramach realizacji tematu badawczego „Prawno-społeczne wyzwania ochrony zdrowia psychicznego" nr 502-03/6-074-06/502-64-103. Temat ten autor realizuje na Uniwersytecie Medycznym w Łodzi. 


\section{Wstęp}

W ciągu ostatnich kilku lat środki masowego przekazu wielokrotnie informowały opinię publiczną o działaniach prawno-medycznych podejmowanych wobec osób podejrzanych o popełnienie szczególnie szokujących przestępstw. Przykładem może być w tym miejscu m.in. sprawa Andersa Brevika, oskarżonego oraz skazanego przez sąd za morderstwo popełnione na ponad siedemdziesięciu osobach na wyspie Utoya oraz w norweskiej stolicy Oslo. Casus ten stał się istotnym elementem debat resocjalizacyjnych oraz prawno-psychiatrycznych, analizujących współczesne możliwości obiektywnej oceny poczytalności sprawców ciężkich przestępstw² ${ }^{2}$ Podobne zainteresowanie od początku 2016 r. budzi sprawa Kajetana P., który jest podejrzany o zamordowanie ze szczególnym okrucieństwem lektorki języka włoskiego. W obu z powyżej przedstawionych przypadków lekarze psychiatrzy mieli istotne wątpliwości odnośnie poczytalności osób podejrzanych o morderstwa ${ }^{3}$. Z kolei pod koniec marca 2017 r. powróciła sprawa tzw. Wampira z Bytowa, Leszka Pękalskiego, który na początku lat 90. ubiegłego wieku oskarżony został o dokonanie kilkunastu morderstw na tle seksualnym. Również w jego przypadku biegli zwracali uwagę na skomplikowany charakter osobowości, który w sposób wyraźny wpływał na problem z ustaleniem jakie działania korekcyjne posiadać będą w odniesieniu do jego osoby najlepszy efekt ${ }^{4}$. Każda z przywołanych w tym miejscu spraw w sposób oczywisty odnosiła się do problematyki procedur, metod oraz profesjonalizmu ekspertyz wykonanych przez biegłych z zakresu psychiatrii, psychologii oraz seksuologii ${ }^{5}$. Analizując podobne $c a-$ susy, znacznie rzadziej zwraca się uwagę na szczególną sytuację, w jakiej znajduje się zarówno badany, jak i oceniający jego stan zdrowia psychicznego ekspert. Sytuacja ta kieruje nas bowiem do problemu szeroko rozumianej tajemnicy medycznej. Podejrzany o dokonanie konkretnego przestępstwa (przestępstw) znajduje się bowiem w położeniu, w którym zmuszony jest decyzją sądu do stawienia się na badanie, w którym medyczny ekspert oceni, czy badany był poczytalny w trakcie dokonywania czynu karalnego, czy też jego zachowanie daje podstawy by uznać, że podobny stan nie był jego udziałem. Jest to de facto jeden z pierwszych elementów mających kluczowe znaczenie $\mathrm{w}$ dalszym postępowaniu wychowawczo-resocjalizacyjnym. W trakcie podobnego spotkania osoba badana przedstawia niejednokrotnie liczne informacje

2 J. Parnas, The Breivik case and “conditio psychiatrica”, „World Psychiatry”, nr 12/2013, s. 22-23.

${ }^{3}$ Materiał: TVN24 nieoficjalnie: w opinii bieglych Kajetan P. niepoczytalny, TVN24: http:// tvnwarszawa.tvn24.pl/informacje,news,tvn24-nieoficjalnie-w-opinii-bieglych-kajetan-p-niepoczytalny,217556.html, (dostęp: 02.04.2017).

${ }^{4}$ B. Kmieciak, Psychopatia, czyli zaburzone zło, „Psychiatria - pismo dla lekarzy”, nr 4, 2016/70-75 oraz Depesza PAP, „Wampir z Bytowa” kończy swój wyrok. Opuści więzienie, „Wprost”, https://www.wprost.pl/kraj/10043686/Wampir-z-Bytowa-konczy-swoj-wyrok-Opusci-wiezienie. html (dostęp: 02.04.2017)

${ }^{5}$ Zob.: E. Waszkiewicz, Czyżby zmierzch psychiatrii?, „Psychiatria - pismo dla praktyków”, nr 7/2017, s. 12- 13 . 
ukazujące przebieg poszczególnych zdarzeń. Bywa, że w trakcie wypowiadania podobnych treści ukazane zostają konteksty lub wydarzenia, które sugerują biegłemu, że jego pacjent w istocie przyznał się do winy. Zdarza się, że badany pacjent wprost przyznaje się ekspertowi do popełnienia czynu zabronionego pod groźbą kary. W Polsce od ponad dwudziestu lat obowiązują przepisy Ustawy o ochronie zdrowia psychicznego (dalej ustawa o o.z.p.). Zgodnie z treścią art. 52. 1 wskazanego aktu prawnego

nie wolno przesłuchiwać osób obowiązanych do zachowania tajemnicy, stosownie do przepisów niniejszego rozdziału, jako świadków na okoliczność wypowiedzi osoby, wobec której podjęto czynności wynikające z niniejszej ustawy, co do popełnienia przez nią czynu zabronionego pod groźbą kary.

Jak dodano w ustępie 2. cytowanego unormowania, zakaz określony $w$ ust. 1 stosuje się odpowiednio do lekarzy wykonujacych czynności biegłego ${ }^{6}$. Już sama lektura wskazanego w tym miejscu przepisu sugeruje, że odnosi się on do gwarancji o absolutnym charakterze. Nie tylko biegły psychiatra, ale także inne osoby uczestniczące w działaniach przewidzianych w ustawie o o.z.p. posiadają zagwarantowaną możliwość odmówienia składania wyjaśnień odnośnie przyznania się przez np. pacjenta do czynów zabronionych pod groźbą kary. Mowa zatem także o innych specjalistach, takich jak: terapeuta zajęciowy, terapeuta uzależnień czy też specjalizujący się w resocjalizacji pedagog pracujący na terenie szpitalnego oddziału więziennego. Uprawnienie to w sposób szczególny odniesione zostaje jednak do postaci biegłego, w tym wypadku lekarza.

\section{Cel oraz metoda pracy}

W tym miejscu warto zwrócić uwagę, że lekarz psychiatra postawiony został przez ustawodawcę w szczególnej sytuacji. Zobowiązany on bowiem jest do zachowania poufności informacji, które w sposób pośredni lub bezpośredni wskazują na winę badanej osoby. Nie może on zatem wiedzą tą dzielić się z innymi ekspertami, w tym np. terapeutami. Warto w tym miejscu zastanowić się jednak: czy istotnie zatem tajemnica psychiatryczna posiada absolutne oblicze? Czy są „w niej” niejako obszary, które nie mogą być w jakikolwiek sposób naruszone? Być może pomimo zapisów utrwalonej w polskim porządku prawnym ustawy o o.z.p., dostrzec można nowe, problemowe obszary, dotyczące zarówno praw pacjenta, jak i szczególnego kontekstu zasad wykonywania zawodu przez lekarza?

Odpowiedź na wskazane w tym miejscu pytania badawcze ${ }^{7}$ poszukiwana będzie przede wszystkim poprzez odniesienie do zapisów polskiego ustawodawstwa oraz literatury przedmiotu, która zarówno z perspektywy medycznej, jak i prawnej, ukazuje

${ }^{6}$ Ustawa z dnia 19 sierpnia 1994 r. o ochronie zdrowia psychicznego, Dz. U. Nr 111, poz. 535 z późn. $\mathrm{zm}$.

${ }^{7}$ B. Earl, Badania społeczne w praktyce, Wydawnictwo Naukowe PWN, Warszawa 2004, s. 351. 
złożony charakter tajemnicy psychiatrycznej ${ }^{8}$. W ramach prezentowanych refleksji oraz przeprowadzanej analizy teoretyczno-badawczej autor korzystać będzie również z informacji uzyskach dzięki wykorzystaniu metody obserwacji uczestniczącej (ukrytej oraz jawnej). Informacje te bazować będą głównie na sytuacjach dostrzeżonych przez autora na terenie szpitali psychiatrycznych'. Szczególny charakter tajemnicy psychiatrycznej warto ukazać, bazując na konkretnym przykładzie.

\section{Przykład}

Do szpitala psychiatrycznego przyjęty został pacjent X. Osoba ta znana była już lekarzom w związku z wcześniejszymi hospitalizacjami. U pacjenta zdiagnozowano kilka lat wcześniej schizofrenię paranoidalną. Wypowiadał treści o charakterze urojeniowym. Przyznawał się do zachowań agresywnych w stosunku do innych osób. W pewnym momencie $\mathrm{w}$ trakcie rozmowy $\mathrm{z}$ ordynatorem przyznał się do zabicia swojego kolegi z pokoju, na terenie domu opieki, w którym wówczas mieszkał. Stwierdził ponadto, że chce to powtórzyć. Z kolei lekarz kilka dni później dowiedział się w trakcie koleżeńskiej rozmowy, że w ośrodku, w którym przebywał pacjent, faktycznie jedna osoba zmarła w okolicznościach zbliżonych do tych, które przedstawił $\mathrm{w}$ rozmowie pacjent.

\section{Tajemnica lekarska - uwagi ogólne}

Zaprezentowany powyżej przykład ukazuje z całą pewnością sytuację o charakterze dramatycznym. Nagle bowiem, w trakcie badania, pacjent przyznaje się lekarzowi, że dokonał czynu zabronionego pod groźbą kary. Warto podkreślić, że mowa jest tutaj o szczególnym czynie, jakim jest pozbawienie drugiej osoby życia. Analizując podobną sytuację zarówno z perspektywy praw pacjenta, jak i zasad wykonywania zawodu przez lekarza, bez trudu dostrzec można unormowania, które wprost odnosić się mogą do podobnej sytuacji.

W pierwszym rzędzie, bazując na zapisach Ustawy o prawach pacjenta i Rzecznika Praw Pacjenta (dalej ustawa o RPP), wskazać należy na treść art. 13 tego aktu prawnego, który stanowi, że:

${ }^{8}$ S. Juszczyk, Badania jakościowe w naukach społecznych - szkice metodologiczne, Wydawnictwo Uniwersytetu Śląskiego, Katowice 2013, s. 8-11.

9 Obserwacje te prowadzone były przez autora przez blisko osiem lat w trakcie pełnienia funkcji Rzecznika Praw Pacjenta Szpitala Psychiatrycznego. Na temat omawianej metody obserwacji - zob.: P. Chomczyński, Wybrane problemy etyczne $w$ badaniach. Obserwacja uczestniczaca ukryta, „Przegląd socjologii jakościowej”, nr 1/2006, s. 68-87. 
pacjent ma prawo do zachowania w tajemnicy przez osoby wykonujące zawód medyczny, w tym udzielające mu świadczeń zdrowotnych, informacji z nim związanych, a uzyskanych w związku z wykonywaniem zawodu medycznego ${ }^{10}$.

Art. 14 ust. 2 pkt. 2 tej ustawy zwraca jednakże uwagę, że personel medyczny (mowa w tym miejscu także o specjalistach takich jak ww. terapeuci zajęciowi lub specjaliści terapii uzależnień), nie ma w obowiązku zachowania w tajemnicy informacji związanych z pacjentem, gdyby działania te miały stanowić niebezpieczeństwo dla życia lub zdrowia pacjenta lub innych osób. Jak podkreśla Dorota Karkowska,

w tych okolicznościach uzasadnienie uchylenia tajemnicy musi być realne, powinno istnieć racjonalne przekonanie, że pacjent nie dokona samodzielnie ostrzeżenia osoby trzeciej, która jest narażona na ryzyko większe niż minimalne. Ustawodawca nie wskazuje przy tym, jakie to będą sytuacje. Jest to ogólna przesłanka określająca wyjątek od zachowania w poufności informacji o osobie pacjenta ${ }^{11}$.

Ujawnienie informacji, co istotne, zależy przede wszystkim od eksperta medycznego, w tym przypadku - lekarza. Pacjent nie ma możliwości zabronić mu podjęcia działań denuncjacyjnych. W praktyce jednak, jak dostrzega Małgorzata Dziewanowska, prawo pacjenta do poufności naruszone zostaje przede wszystkim z racji na nieformalne relacje, jakie np. lekarza łączą z rodzina pacjenta ${ }^{12}$. Koniecznym jest w tym miejscu dostrzeżenie, że lekarz (lub też terapeuta) znajdować się może w położeniu, w którym zobowiązany będzie do ujawnienia np. instytucjom państwowym informacji przedstawionych przez pacjenta. Na podobną możliwość wskazują zarówno przepisy ustawowe, jak i normy deontologiczne, do których przestrzegania zobowiązany jest lekarz. Z jednej zatem strony warto wskazać treść art. 40 ust. 2 pkt. 3 ustawy o zawodach lekarza i lekarza dentysty, który - podobnie jak w przywołanej „pacjenckiej ustawie” - wskazuje, że lekarz nie jest zobowiązany do zachowania poufności informacji dotyczących pacjenta, gdy zachowanie tajemnicy może stanowić niebezpieczeństwo dla życia lub zdrowia pacjenta lub innych osób ${ }^{13}$. Z drugiej natomiast perspektywy konieczne jest dodanie, że również zasady etyczne, dotyczące wykonywania przez lekarzy zawodu, zwalniają owych specjalistów z obowiązku zachowania poufności, w chwili, w której to jej zachowanie w sposób istotny zagrażać może osobie pacjenta lub innych osób ${ }^{14}$.

${ }^{10}$ Ustawa z dnia 6 listopada 2008 r. o prawach pacjenta i Rzeczniku Praw Pacjenta,. Dz. U. Nr 111, poz. 535 z późn. zm.

${ }_{11}$ Tamże.

${ }_{12}$ M. Dziewanowska, Prawa pacjenta-prawno-zdrowotny poradnik dla kobiet, Warszawa 2009, s. 8.

${ }^{13}$ Ustawa z dnia 5 grudnia 1996 r. o zawodach lekarza i lekarza dentysty, Dz. U. Nr 226, poz. 1943 z późn. zm.

${ }^{14}$ Por.: art. 25 Kodeks Etyki Lekarskiej z dnia 2 stycznia 2004 r., (tekst jednolity; zawierający zmiany uchwalone w dniu 20 września 2003 r. przez Nadzwyczajny VII Krajowy Zjazd Lekarzy), Warszawa 2004. 
Odnosząc się w tym miejscu do perspektywy prawnej, warto zwrócić uwagę na kluczowe spostrzeżenia dotyczące faktycznej konieczności podjęcia działań denuncjacyjnych w związku z deklaracją wygłoszoną przez pacjenta. Rafał Kubiak, dokonując pogłębionej analizy od strony prawa karnego w omawianej materii, zwraca uwagę, że w pierwszej kolejności musimy odpowiedzieć sobie, czy lekarz:

A) jest zobowiązany do podobnych działań? (jeśli ich nie podejmie nie spotka go sankcja karna);

B) jest zobowiązany do upewnienia tajemnicy? (może spotkać go kara za brak podjęcia takich działań);

C) ma możliwość denuncjacji, ale nie ma takiego obowiązku?

Odniesienie się do konkretnego zakresu w omawianej materii posiada szczególne znaczenie również z perspektywy dalszej analizy problematyki prawno-psychiatrycznej oraz resocjalizacyjnej. Kubiak słusznie wskazuje, że klasycznym przykładem sytuacji zawartej w pkt A. jest zobowiązanie, jakie ustawodawca nałożył na licznych ekspertów w treści art. 12 ustawy o przeciwdziałaniu przemocy w rodzinie. Unormowanie to dotyczy zatem już nie tylko lekarza, ale także personelu pedagogicznego pracującego na terenie szkoły lub określonego ośrodka wychowawczego ${ }^{15}$. Przywołany w tym miejscu karnista zaznacza jednakże, że tytuł ustawy, a wiec również ww. obowiązek, odnosi się do relacji rodzinnych. Tym samym zawarty w przepisie denuncjacyjny rygor nie ukazuje nam istnienia obowiązku informowania o przemocy jaką np. podejmuje konkubent matki pobitego dziecka lub jego nauczyciel: nie są oni bowiem rodziną i w tym ujęciu wskazane przepisy nie maja zastosowania. Ponadto, jak dodaje Kubiak, brak zawiadomienia policji lub prokuratury w wypadku podejrzenia przestępstwa nie wiąże się z pojawieniem się obawy o potencjalne doświadczenie sankcji. W przepisie tym dostrzegamy bowiem hipotezę oraz dyspozycję: wiemy czego i kogo dotyczy przepis. Nie zawarto w niej natomiast sankcji, a wiec kary ${ }^{16}$. Innego zdania w omawianej kwestii jest Mirosław Nesterowicz. Autor ten zaznacza bowiem, że lekarz jest obowiązany odstąpić od tajemnicy de facto $w$ każdej sytuacji, w której posiada pewność lub uzasadnione podejrzenie, że rozstrój zdrowia, uszkodzenia ciała lub śmierć pacjenta powstały $w$ związku $z$ przestępstwem ${ }^{17}$. Wskazana powyżej Dorota Karkowska - co wydaje się konieczne do dopowiedzenia - zaznacza, że ustawodawca dopuszcza wkroczenie w obszar tajemny zawodowej, ale jedynie w chwili, w którym dostrzeżona zostanie kluczowa wartość społeczna ujawienia szczególnych informacji, które dotąd stanowiły element tajemnicy lekarskiej ${ }^{18}$. W tym miejscu odnieść się można do sytuacji przywołanej w pkt. B). Jako przykład podobnych działań wskazuje się w doktrynie potencjalne zdarzenia, które wymienione zostały w art. 240 par. 1

15 Ustawa z dnia 29 lipca 2005 r. o przeciwdziałaniu przemocy w rodzinie, Dz. U. 2005 nr 180 poz. 1493.

16 R. Kubiak, Prawo medyczne, Wydawnictwo C.H. Beck, Warszawa 2010, s. 274-277.

17 M. Nesterowicz, Prawo medyczne, Wydawnictwo Dom Organizatora, Toruń 2005, s. 187.

18 D. Karkowska, Prawa pacjenta, Wydawnictwo ABC, Warszawa 2004. s. 558-559. 
Kodeksu karnego ${ }^{19}$. Mowa zatem o sytuacji, w której lekarz (lub też inny specjalista: psycholog, terapeuta uzależnień) przykładowo dowiaduje się nie tylko o podejmowanych przez pacjenta działaniach terrorystycznych, ale wie także, że dana osoba usiłowała, dokonała lub planuje popełnić przestępstwo w postaci: zabójstwa, uwiezienia określonej osoby lub stwarzania niebezpieczeństwa dla wielu osób ${ }^{20}$. W tym miejscu odnosimy się do potencjalnej sytuacji wskazanej w pkt. C) omawianych rozważań. Najczęściej bowiem lekarz, psycholog lub terapeuta pracujący z rodziną nie posiada dokładnych informacji dotyczących: specyfiki i dynamiki zdarzeń, kontekstu sytuacyjnego oraz realnych, prawdziwych okoliczności związanych z niepokojąca wypowiedzią pacjenta. Badany może przykładowo stwierdzić, że jego córka w sposób dotkliwy bije swoje dziecko. Trudno jednakże w tym miejscu uznać, czy pacjent faktycznie ma córkę oraz wnuczkę. Nawet jeśli osoby takie istnieją, to lekarz nie posiada w tym momencie informacji wskazujących na to, które twierdzenia są prawdziwe, a które fałszywe. Tym samy, możemy w podobnym kontekście mówić o możliwości ujawnienia informacji, a nie o obowiązku²1.

Podsumowując przywołane w tym miejscu rozważania dotyczące tajemny lekarskiej, warto zwrócić uwagę, że wszelka dyskusja dotycząca możliwości ujawnienia poufnych informacji dotyczących pacjenta to wyzwanie nie tylko o prawnym, ale również i etycznym charakterze. Warto bowiem przypomnieć, że już w Przysiędze Hipokratesa adepci sztuki lekarskiej zobowiązani zostali do zachowania w poufności informacji dotyczących osób diagnozowanych oraz leczonych ${ }^{22}$. Krzysztof Szczygiel, ukazując szczególny kontekst etyczny zasady poufności medycznej wskazuje, że stanowi ona istotny element chroniący godność człowieka. Autor ten trafnie zaznacza, że zagrożenia dla omawianej zasady mogą pojawiać się zarówno po stronie osób chcących uzyskać bezprawnie informacje o pacjencie od np. lekarza, jak i ze strony wskazanego, medycznego eksperta. $Z$ jednej bowiem strony dana osoba może $z$ racji doświadczanej ciekawości dążyć do uzyskania informacji, której nie ma prawa posiadać. Działania te mogą być podjęte również w formie określonego przymusu. Z drugiej natomiast strony to sam lekarz może w sposób niepotrzebny ingerować w intymną sferę leczonego pacjenta. Szczygiel zaznacza jednak, że poufność terapeutyczna odnosi się do newralgicznej sytuacji, a więc momentu trudnego, związanego $z$ chorobą ${ }^{23}$. Uwagę tę warto uzupełnić o interesujący nas w tym miejscu kontekst psychologiczny.

${ }^{19} \mathrm{Na}$ początku kwietnia 2017 r. opublikowana została nowelizacja omawianego kodeksu. Odnosiła się ona również do treści art. 240 par. 1. Dla proponowanych w tym miejscu rozważań generalnych, zmiany te $-\mathrm{z}$ całą pewnością istotne dla praktyki orzeczniczej - nie mają jednakże kluczowego znaczenie. Ustawa z dnia 6 czerwca 1997 r. - Kodeks karny, Dz. U. 1997 nr 88 poz. 553.

${ }_{20}$ Zob. J. Bujny, Prawa pacjenta - między autonomiq a paternalizmem, Warszawa 2007, s. 187-188.

${ }^{21}$ B. Kmieciak, Prawa dziecka jako pacjenta, Wydawnictwo C.H. Beck, Warszawa 2016, s. 30-32.

22 T. Biesaga, Przysięga Hipokratesa a etyka medyczna, „Medycyna Praktyczna”, nr 7-8/2006, s. 20.

${ }^{23}$ K. Szczygiel, Tajemnica lekarska, [w:] A. Muszala (red.), Encyklopedia bioetyki, Wydawnictwo Polwen, Radom 2009, s. 600-602. 
Marek Jarosz, ojciec polskiej psychologii lekarskiej, słusznie zwraca uwagę, iż lekarz $\mathrm{z}$ całą pewnością może być silnym sprzymierzeńcem pacjenta. Jak zauważa, regularne informowanie pacjenta o podejmowanych działaniach oraz o jego obecnym stanie zdrowotnym w sposób istotny wpływać może na obniżenie u niego poziomu lęku, przy jednoczesnym zwiększaniu poczucia bezpieczeństwa ${ }^{24}$. Dojść zatem można do wniosku, iż zachowanie przez medycznego eksperta poufności posiadać będzie podobny, terapeutyczny efekt.

\section{Tajemnica psychiatryczna}

Bazując na powyższych uwagach warto odnieść się w sposób bezpośredni do zagadnienia tajemnicy psychiatrycznej. Powracając zatem do zaproponowanego powyżej przykładu koniecznym wydaje się rozważenie, czy personel medyczny: miał możliwość, prawo czy też obowiązek powiadomienia organów ścigania. Być może przeciwnie - nie miał de facto takiego prawa?

Analizując przykład przyznania się do popełnienia czynu zabronionego, przy jednoczesnej deklaracji aktualnie doświadczanego pragnienia wyrządzenia szkody innym osobom, w sposób nieświadomy wpaść można w swoistą pułapkę. Już bowiem na poziomie badania przyczyn przyjęcia pacjentów do szpitali psychiatrycznych lub oddziałów somatycznych dostrzec należy kluczową różnicę. Nie chodzi w tym miejscu o specyfikę zaburzenia psychicznego. Mowa raczej o zdarzeniach, w których to pacjent przyjmowany jest do oddziału wbrew swojej woli. Jak stanowią przede wszystkim art. 23, 24, a także art. 28 ustawy o p.z.p., podobne działanie przymusowe możliwe jest do podjęcia przede wszystkim w chwili zdiagnozowania u pacjenta występowania choroby psychicznej (w przypadku art. 24 mowa o podejrzeniu występowania choroby). Podobnej diagnozie musi jednakże towarzyszyć również kluczowy element behawioralny, a więc występowanie u pacjenta zachowań zagrażających jego życiu lub zdrowiu i życiu innych osób ${ }^{25}$. Tym samym dostrzec należy, że w wielu przypadkach pacjent przyjmowany w tzw. trybie nagłym może wypowiadać treści, które w innych okolicznościach uznane winny być za groźby o charakterze karalnym, lub też wypowiedzi świadczące np. o przygotowywanym zamachu, kierowanym przeciwko konkretnej osobie. Na podobny element słusznie uwagę zwrócili Joanna Różyńska i Jacek Hołówka. Wspomniani badacze podkreślają, że denuncjacja pacjenta zgłaszającego np. występowanie myśli agresywnych, których finałem może być zamach, to w istocie problem nie tylko prawny, ale również i etyczny. $Z$ jednej strony kluczowy w tym

${ }^{24}$ A. Kaźmierczak, Doświadczenie choroby przez pacjentów z perspektywy relacji z personelem medycznym, [w:] B. Płonka-Syroka, M. Skrzypek (red.), Doświadczanie choroby w perspektywie nauk humanistycznych, społecznych i medycznych, Wydawnictwo Akademii Medycznej im. Piastów Śląskich, Wrocław 2010, s. 230.

25 D. Karkowska, Prawa pacjenta psychiatrycznego, [w:] M. Wojciechowska (red.), Problemy zdrowia psychicznego, Wydawnictwo AHE, Łódź 2010, s. 149-150. 
miejscu winien być element posiadania przez psychiatrę lub innego terapeutę konkretnej wiedzy. Szczególnie istotne jest, czy specjalista wie o realnej osobie, której grozić może niebezpieczeństwo. Z drugiej natomiast perspektywy nie bez znaczenia jest w tym miejscu obawa środowiska psychiatrycznego. W pierwszym bowiem rzędzie lekarze mogą obawiać się, iż pacjenci (wiedząc, że będą oni ujawniać tajemnicę) nie wykształcą w sobie zaufania kluczowego np. w psychoterapii. Po drugie, zdaniem Różyńskiej i Hołówki warto dostrzec, że czynna realizacja wypowiadanych przez pacjentów agresywnych gróźb należy do rzadkości. Tym samym regularne powiadamianie przez lekarzy określonych osób, którym grozi potencjalne niebezpieczeństwo, mogłoby być wykorzystywane przez część pacjentów jako forma manipulacji lekarzami oraz osobami (potencjalnymi ofiarami) ${ }^{26}$.

Podobny dylemat posiada z całą pewnością trudny charakter i może być istotnym obciążeniem w pracy lekarza lub innego ekspert udzielającego wsparcia danej osobie w jej kryzysie psychicznym. Konieczne jest jednak w tym miejscu dodanie, że przyjęcie pacjenta do szpitala bez zgody w związku z występowaniem objawów psychotycznych, które jednocześnie powodują zagrożenie społeczne, to stan, który nie może być automatycznie traktowany jako występowanie potencjalnego przestępstwa. Wskazany we wstępie przykład doskonale pokazuje podobny kontekst. Pacjent wypowiada bowiem treści, które w sposób naturalny wzbudzać mogą niepokój u lekarza. Może on się obawiać, iż dojdzie z czasem do nieuniknionej tragedii. Przekonanie to wzmacniane jest również informacjami dotyczącymi przyznania się pacjenta do zabójstwa i uzyskaną w następnej kolejności wiedzą dotyczącą śmierci jednego z pensjonariuszy. Choć zbieg podobnych zdarzeń wzmacnia zarówno obawy, jak i przekonanie o konieczności podjęcia działań denuncjacyjnych, to jednocześnie nie zmienia on kluczowego dla tajemnicy psychiatrycznej kontekstu wskazującego na jej absolutne elementy. Przywołane w tym miejscu słowo „elementy” posada istotne znaczenie. Błędem jest bowiem uznanie, że wszelka wiedza o charakterze informacji psychiatrycznej posiada niemożliwy do ujawnienia charakter. W podobnym ujęciu mielibyśmy do czynienia z tajemnicą spowiedzi, która w żadnych okolicznościach nie ulega ujawnieniu ${ }^{27}$. W odniesieniu do tajemnicy psychiatrycznej należy tym samym zaznaczyć, że możliwe jest ujawnienie informacji dotyczących pacjenta w sytuacjach wskazanych w art. 50 ust. 2 ustawy o o.z.p. Przekazanie zatem danych dotyczących pacjenta innemu lekarzowi przejmującemu nad nim medyczną opiekę, wskazanie poszczególnym służbom ochrony państwa, czy dana osoba się leczy/leczyła, lub też poinformowanie o powyższym konkretny organ pomocy społecznej, to działania, które nie mogą być uznane za naruszenie zasad dochowania tajemnicy psychiatrycznej. W tym miejscu należy jednak pamiętać, że mowa jest o przekazaniu kluczowych

${ }^{26}$ J. Różyńska, J. Hołówka, Tajemnica lekarska, [w:] J. Różyńska, W. Hańska (red.), Bioetyka, Wydawnictwo Wolter Kluwer, Warszawa 2013, s. 130-133.

${ }_{27}$ Por.: M. Leciak, Nowe regulacje tajemnic prawnie chronionych w projekcie zmian KPK, „Kwartalnik Krajowej Szkoły Sądownictwa i Prokuratury”, nr 3/2012, s. 7-9. 
informacji. W kontekście np. ww. służb ochrony państwa lekarz nie może przedstawić uprawnionemu funkcjonariuszowi pełnej wiedzy klinicznej dotyczącej np. kandydata na agenta wywiadu. Powinien jednakże powiadomić go, jeśli ten był pacjentem poradni zdrowia psychicznego lub też poradni leczenia uzależnień. Informacje te są szczególnie istotne $\mathrm{z}$ racji na poszanowanie bezpieczeństwa publicznego ${ }^{28}$.

W tym jednakże miejscu koniecznie należy podkreślić, że analizując specyficzne zjawisko, jakim jest tajemnica psychiatryczna - jak zaznaczono - bez trudu dostrzec można jej absolutne elementy uniemożliwiające podjęcie działań denuncjacyjnych.

Powracając do sytuacji ze wskazanego przykładu, należy dojść do wniosku, że mamy do czynienia właśnie z podobnym zdarzeniem. Psychiatra znalazł się bowiem w położeniu, w którym nie posiadał prawa do utrwalenia w dokumentacji medycznej pacjenta jego oświadczenia obejmującego przyznanie się do winy (art. 51 ustawy o o.z.p.). Gdyby informacja ta (fakt przyznania się pacjenta do winy) ujrzała światło dzienne, badający go w szpitalu lekarz oraz wyznaczony przez sąd biegły nie mogliby być przesłuchani jako świadkowie na okoliczność wypowiedzi osoby, wobec której podjęto czynności wynikające z niniejszej ustawy, co do popetnienia przez nia czynu zabronionego pod groźba kary (art. 52. ust. 1 ustawy o o.z.p.). Stanisław Dąbrowski oraz Janusz Pietrzykowski, analizując wskazane w tym miejscu unormowanie, zaznaczają, że celem tajemnicy psychiatrycznej jest ochrona pacjenta znajdującego się w specyficznej sytuacji klinicznej. Ich zdaniem lekarz psychiatra (oraz psycholog i inny terapeuta) w wielu wypadkach może zostać powiadomiony przez pacjenta o działaniach, które posiadają bezsprzeczny charakter przestępstwa. Zdarza się, że treści te posiadają formę patologiczną, ergo pacjent wypowiada np. informacje wskazujące, iż to on w przeszłości zamordował dyktatora określonego państwa. Tym samym dla lekarza wiedza ta ma cenny charakter diagnostyczny, umożliwiający pełne spojrzenie na stan badanego pacjenta, bez względu na to, czy treści te posiadają oblicze urojone, czy też zgodne z prawdą. Konieczność powiadomienia określonych organów o dokonanym przez pacjenta przestępstwie uniemożliwiałaby de facto wykonywanie zawodu przez np. lekarza psychiatrę, psychologa lub specjalistę terapii uzależnień.. Jednak wskazani w tym miejscu autorzy, co interesujące, zaznaczają, że pojawienie się ze strony pacjenta gróźb pro futuro zwalania lekarza z obowiązku zachowania tajemnicy. Ich zdaniem psychiatra jest bowiem przede wszystkim lekarzem i w chwili wystąpienia zagrożenia dla zdrowia lub życia innych osób winien on zawiadomić organy ścigania ${ }^{29}$. Piotr Gałecki, Kinga Bobińska i Krzysztof Eichstaedt w ostatnim z komentarzy do ustawy o o.p. z również zwracają uwagę na nie w pełni absolutny charakter zakazu denuncjacyjnego w instytucji tajemnicy psychiatrycznej. Dostrzegają oni bowiem, że zakaz ten dotyczy wyłącznie przestępstw popełnionych na terenie Polski. Jednocześnie ich

${ }^{28}$ P. Gałecki, K. Bobińska, K. Eichstaedt, Ustawa o ochronie zdrowia psychicznego - komentarz, Wydawnictwo LexisNexis, Warszawa 2013, s. 215-216.

${ }^{29}$ S. Dąbrowski, J. Pietrzykowski, Ustawa o ochronie zdrowia psychicznego. Komentarz, Wydawnictwo Instytutu Psychiatrii i Neurologii, Warszawa 1997, s. 221-222. 
zdaniem tajemnica psychiatryczna posiada szerszy charakter niż tajemna lekarska. Zgadzając się z Dąbrowskim i Pietrzykowskim dodają, że nie może zwolnić z niej lekarza nawet sam pacjent ${ }^{30}$. Juliusz Duda - autor drugiego komentarza do omawianej ustawy - zauważa jednakże, że bezwzględny zakaz dowodowy zapisany w art. 52 ust. 1 ustawy o o.z.p. stał się obiektem zainteresowania doktryny. M.in. Marian Filar w swoich analizach prawno-karnych kontestował jego absolutny charakter. Wskazany autor zauważył bowiem, że sąd może zwolnić z tajemnicy lekarza psychiatrę na podstawie art. 180 par. 2 k.p.k. ${ }^{31}$ Duda podkreśla jednak - z czym trzeba się zgodzić - że w podobnej sytuacji dostrzec należy istotną niekonsekwencję, a nawet sprzeczność. $\mathrm{Z}$ jednej bowiem strony sąd może w podobnym ujęciu zwolnić lekarza $\mathrm{z}$ obowiązku zachowania tajemnicy, $z$ drugiej jednak perspektywy ów psychiatra ma prawo, powołując się na przywołany przepis, odmówić składania zeznań, które wiązać by się mogły z ujawnieniem kluczowych informacji związanych z przyznaniem się pacjenta do winy w określonej sprawie. ${ }^{32}$

\section{Wnioski}

Przechodząc do konkluzji wskazanych rozważań, należy wskazać na szczególny problem, który coraz częściej podnoszony jest przez doktrynę. Jak podkreślono powyżej, analizując zakres, jakim objęta jest tajemnica psychiatryczna, dostrzec należy przede wszystkim zagadnienia dotyczące przeszłości pacjenta oraz aktualnego jego stanu, np. w momencie przyjmowania go do szpitala. W przedstawionym na początku przykładzie uwaga zwrócona została również na działania, jakie pacjent planuje. Czy zatem lekarz, psycholog, lub inny terapeuta w podobnej sytuacji może ujawnić niepokojącą go informację organom ścigania?

W toku zaproponowanych analiz i refleksji pojawił się wniosek, który mówi, że w omawianym casusie jest to niemożliwe. Po pierwsze, pacjent doświadczał zaburzeń psychotycznych, a po drugie - jego deklaracje posiadały niezwykle ogólny charakter. $\mathrm{W}$ istocie nie wiadomo, kogo należałoby powiadomić o powyższym. Sytuacja ulega jednakże diametralnej zmianie w momencie, w którym to zwrócimy uwage na pacjenta, który nie tylko nie prezentuje podobnych chorobowych objawów wytwórczych, ale co istotniejsze, wypowiada np. groźby skierowane wobec konkretnej osoby, a dany specjalista posiada jednocześnie przekonanie, że może je on zrealizować. Tym samym nie mamy tutaj do czynienia z czynnością, która już została dokonana, ale $\mathrm{z}$ dużym prawdopodobieństwem będzie miała dopiero miejsce. Mowa np. o przestępstwach wymienionych w art. 240 par. 1 k.k. Pomijając w tym miejscu dywagację

30 P. Gałecki, K. Bobińska, K. Eichstaedt, dz. cyt, s. 218

31 Ustawa z dnia 6 czerwca 1997 r., Kodeks Postępowania Karnego Dz. U. 89 poz. 555 ze zm.

32 J. Duda, Komentarz do Ustawy o ochronie zdrowia psychicznego. Komentarz, Wydawnictwo LexisNexis, Warszawa 2006, s. 209. 
teoretyczną, należy podkreślić, iż podobna sytuacja stanowi przede wszystkim szczególne obciążenie dla lekarzy, pielęgniarek, a także terapeutów pracujących z osobami doświadczającymi zaburzeń psychicznych. To oni bowiem mają świadomość, że stan pacjenta wskazuje na istotne prawdopodobieństwo pojawienia się podobnej, dramatycznej w skutkach sytuacji. Czy postępowanie personelu medycznego winno być w tym miejscu inne? Czy powinna nastąpić denuncjacja? Artur Hącia zwraca uwagę, że z perspektywy etycznej złamanie tajemnicy możliwe jest tylko w nadzwyczajnych okolicznościach (np. zagrożenie życia), jednak pacjent powinien zostać o tym poinformowany ${ }^{33}$. Także komentatorzy omawianej w tym miejscu ustawy o o.z.p podkreślają, że z jednej strony

w przypadku ujawnienia przez pacjenta zamiaru popełnienia czynu, który ze względu na towarzyszące okoliczności powinien być traktowany poważnie, należy postępować zgodnie z art. 40. ust. 2 pkt 1 u. o z.l. (mowa o ustawie o zawodzie lekarza i lekarza dentysty - przyp. BK). Artykuł 52 u. o o.z.p. jest uzupełnieniem poprzedniego ${ }^{34}$.

Z drugiej strony, w podobnej sytuacji lekarz psychiatra znajduje się w położeniu, w którym musi rozważyć, które dobro jest ważniejsze: szczególne prawo pacjenta do poufności informacji z nim związanych, czy też życie i zdrowie konkretnego człowieka, który może znaleźć się w niebezpieczeństwie. Tym samym podkreślone zostało, że psychiatra może dokonać denuncjacji, odwołując się do stanu wyższej konieczności, a zatem bazując na unormowaniu art. 26 par. 1 k.k. Zasada ta wydaje się być również cenna w wypadku psychologa lub np. pedagoga pracującego jako specjalista terapii uzależnień $^{35}$. Niezwykle trudno polemizować z podobnym poglądem. Gdyby bowiem przyjąć, że podobni specjaliści nie mogą podjąć działań mających na celu ratowanie życia konkretnej osoby, wówczas należy stwierdzić, że tajemnica psychiatryczna w znacznej mierze przypomina tajemnicę spowiedzi, co uznać trzeba za opinię błędną ${ }^{36}$.

Wskazane powyżej dywagacje w sposób nie budzący wątpliwości udowadniają, że relacja pomiędzy prawem a psychiatrią posiada unikatowy charakter. Warto nadmienić, że liczne jej obszary nadal nie są w pełni zgłębione i jednoznaczne. Jak widać, zasadnym jest, by w dalszych, interdyscyplinarnych badaniach poszerzać wiedzę i prowadzić do wyklarowania kwestii prawnych dotyczących tego zagadnienia.

33 A. Hącia, Deklaracja Madrycka. Etyka psychiatryczna w świetle deklaracji etycznych, „Current Problems of Psychiatry", nr 16/2015, s. 13.

${ }^{34}$ A. Gruszczyńska-Młodożeniec, K. Pierzgalska, dz. cyt., s. 298.

${ }^{35}$ P. Gałecki, K. Bobińska, K. Eichstaedt, dz. cyt., s. 225.

${ }^{36}$ Absolutny charakter tajemnicy spowiedzi związany jest przede wszystkim z unikalnym obszarem, jakim jest ludzkie sumienie, będące w sposób szczególny chronioną wartością konstytucyjną. Por:. art. 53 ust. 1 i 2 Ustawy z dnia 2 kwietnia 1997r Konstytucja Rzeczypospolitej Polskiej, Dz. U. Nr 78, poz. 483 z późn. zm. 


\section{Bibliografia}

Biesaga T., Przysiega Hipokratesa a etyka medyczna, „Medycyna Praktyczna”, nr 7-8/2006, s. 20-25.

Bujny J., Prawa pacjenta - między autonomia a paternalizmem, Wydawnictwo C. H. Beck, Warszawa 2007.

Chomczyński P., Wybrane problemy etyczne w badaniach. Obserwacja uczestniczaca ukryta, „Przegląd socjologii jakościowej”, nr 1/2006, s. 68-87.

Gałecki P., Bobińska K., Eichstaedt K., Ustawa o ochronie zdrowia psychicznego - komentarz, Wydawnictwo LexisNexis, Warszawa 2013.

Dziewanowska M., Prawa pacjenta - prawno-zdrowotny poradnik dla kobiet, Federacja na rzecz Kobiet i Planowania Rodziny, Warszawa 2009.

Dąbrowski S., Pietrzykowski J., Ustawa o ochronie zdrowia psychicznego. Komentarz, Wydawnictwo Instytutu Psychiatrii i Neurologii, Warszawa 1997.

Depesza PAP, „Wampir z Bytowa” kończy swój wyrok. Opuści więzienie, „Wprost”, https://www.wprost.pl/kraj/10043686/Wampir-z-Bytowa-konczy-swoj-wyrok-Opusci-wiezienie.html (dostęp: 02.04.2017).

Earl B.. Badania społeczne w praktyce, Wydawnictwo Naukowe PWN, Warszawa 2004, s. 351.

Gruszczyńska-Młodożeniec A., Pierzgalska K., Wybrane zagadnienia prawne w psychiatrii. Wywiad z prof. S. Dąbrowskim, „Wiadomości Psychiatryczne”, nr 4/2004, s. 293-297.

Hącia A., Deklaracja Madrycka. Etyka psychiatryczna w świetle deklaracji etycznych, „Current Problems of Psychiatry”, nr 16/2015, s. 9-17.

Juszczyk S., Badania jakościowe w naukach społecznych - szkice metodologiczne, Wydawnictwo Uniwersytetu Śląskiego, Katowice 2013.

Kmieciak B., Prawa dziecka jako pacjenta, Wydawnictwo C.H. Beck, Warszawa 2016.

Kmieciak B., Psychopatia, czyli zaburzone zło, „Psychiatria - pismo dla lekarzy”, nr 4/2016, s. 70-75.

Kodeks Etyki Lekarskiej z dnia 2 stycznia 2004 r., (tekst jednolity; zawierający zmiany uchwalone w dniu 20 września 2003 r. przez Nadzwyczajny VII Krajowy Zjazd Lekarzy), Warszawa 2004.

Kaźmierczak A., Doświadczenie choroby przez pacjentów z perspektywy relacji z personelem medycznym, [w:] B. Płonka-Syroka, M. Skrzypek (red.), Doświadczanie choroby w perspektywie nauk humanistycznych, społecznych $i$ medycznych, Wydawnictwo Akademii Medycznej im. Piastów Śląskich, Wrocław 2010, s. 223-241.

Karkowska D, Prawa pacjenta psychiatrycznego, [w:] M. Wojciechowska (red.), Problemy zdrowia psychicznego, Wydawnictwo AHE, Łodź 2010, s. 143-157.

Karkowska D., Prawa pacjenta, Wydawnictwo ABS, Warszawa 2004.

Kubiak R., Prawo medyczne, Wydawnictwo C. H. Beck, Warszawa 2010. 
Leciak M., Nowe regulacje tajemnic prawnie chronionych w projekcie zmian KPK, „Kwartalnik Krajowej Szkoły Sądownictwa i Prokuratury”, nr 3/2012, s. 7-9.

Materiał: TVN24 nieoficjalnie: w opinii biegłych Kajetan P. niepoczytalny, „TVN24”: http://tvnwarszawa.tvn24.pl/informacje,news,tvn24-nieoficjalnie-w-opinii -bieglych-kajetan-p-niepoczytalny,217556.html (dostęp: 02.04.2017).

Nesterowicz M., Prawo medyczne, Wydawnictwo Dom Organizatora, Toruń 2005.

Parnas J., The Breivik case and "conditio psychiatric", "World Psychiatry", nr 12/2013, s. $22-23$.

Różyńska J., Hołówka J., Tajemnica lekarska, [w:] J. Różyńska, W. Hańska (red.), Bioetyka, Wydawnictwo Wolters Kluwer, Warszawa 2013, s. 121-135.

Szczygiel K., Tajemnica lekarska, [w:] A. Muszala (red.), Encyklopedia bioetyki, Wydawnictwo Polwen, Radom 2009,

Ustawa z dnia 5 grudnia 1996 r. o zawodach lekarza i lekarza dentysty, Dz. U. Nr 226, poz. 1943 z późn. zm.

Ustawa z dnia 19 sierpnia 1994 r. o ochronie zdrowia psychicznego, Dz. U. Nr 111, poz. $535 \mathrm{z}$ późn. zm.

Ustawa z dnia 6 czerwca 1997r., Kodeks Postępowania Karnego, Dz. U. 89 poz. 555 ze $\mathrm{zm}$.

Ustawa z dnia 2 kwietnia 1997r Konstytucja Rzeczypospolitej Polskiej, Dz. U. Nr 78, poz. 483 z późn. zm.

Ustawa z dnia 6 czerwca 1997 r. - Kodeks karny, Dz.U. 1997 nr 88 poz. 553.).

Ustawa z dnia 6 listopada 2008 r. o prawach pacjenta i Rzeczniku Praw Pacjenta, Dz. U. Nr 111, poz. 535 z późn. zm.

Ustawa z dnia 29 lipca 2005 r. o przeciwdziałaniu przemocy w rodzinie, Dz.U. 2005 nr 180 poz. 1493.

Waszkiewicz E., Czyżby zmierzch psychiatrii?, „Psychiatria - pismo dla praktyków”, nr 7/2017, s. 12-13. 
Psychiatric mystery from the perspective of theoretical and practical challenges: socioethical and legal attention

Abstract: The patient's visit has a special character. It refers to a situation in which one of the people experiences a specific problem. During the visit, important pieces of information are often disclosed. They often relate to the issues that are important for the patient. He wants to leave them in secret. That is why, from a legal and ethical perspective, the medical confidentiality has a unique meaning. Psychiatric confidentiality has a special character in this aspect. Psychiatrist - while doing his job - can obtain information that can indicate a crime committed by the patient. As it turns out, this specialist is obliged in a similar situation - to keep a secret. He cannot notify, for example, the prosecutor's office or the police. Does this mean that the psychiatric confidentiality is absolute? Are there any exceptions? What should a psychiatrist do when a patient is planning to commit a specific crime? The article attempts to answer these questions.

Keywords: patient rights, mental health protection, psychiatric confidentiality, forced treatment, judicial review

\footnotetext{
About the author: Błażej Kmieciak - doctor of social sciences in the field of sociology of law, bioethics and special educator. Assistant professor in the Department of Medical Law, Medical University of Lodz, lecturer in law at the Department of Special Pedagogy of the University of Lodz, former Ombudsman of the Patient Right in the Psychiatric Hospital. Author of publications in the field of sociology and pedagogy of law, medical law and human rights, including book monographs: Patient rights and their protection. Sociological study, Bioethics, between the law and pedagogy (together with Mirosław Kowalski) and The rights of the child as a patient.
} 


\title{
Sylwia Huczuk*
}

Uniwersytet Marii Curie-Skłodowskiej w Lublinie

sylwia.huczuk@gmail.com

\section{Formy pomocy udzielanej nieletnim - podopiecznym ośrodków kuratorskich}

\begin{abstract}
Streszczenie: Nieletni podopieczni ośrodków kuratorskich to osoby przejawiające symptomy demoralizacji w postaci np.: wagarów, uchylania się od obowiązku szkolnego, zażywania środków odurzających w postaci narkotyków lub alkoholu, włóczęgostwa, uprawiania nierządu, popełnienia czynu zabronionego, udziału w grupach przestępczych, naruszania zasad współżycia społecznego. Młodzież kierowana jest do takiej placówki na mocy prawomocnego orzeczenia Sądu rodzinnego, podopieczni ośrodków kuratorskich znajdują się w przedziale wiekowym od 13 do 17 lat. Osoby, wobec których orzeczono środek wychowawczy w postaci umieszczenia w ośrodku kuratorskim, najczęściej pochodzą $\mathrm{z}$ rodzin dysfunkcyjnych, w których występowała przemoc, uzależnienie jednego bądź obojga $\mathrm{z}$ rodziców, bezrobocie, brak miłości, poczucia bezpieczeństwa, zainteresowania ze strony rodzica. Wyżej wymienione czynniki przyczyniają się do wykształcenia u dzieci niskiego poziomu poczucia własnej wartości i samooceny, bierności, życia niezgodnego z prawem. Dlatego też ważna jest pomoc świadczona nieletnim w czasie ich pobytu w ośrodku kuratorskim. Wśród form wsparcia świadczonego młodzieży zdemoralizowanej wyróżnia się oddziaływania w postaci: wsparcia psychologicznego, pedagogicznego, warsztatów z zakresu rozwijania kompetencji społecznych, zajęcia profilaktyczne, treningi relaksacyjne. Oprócz tego należy zwrócić uwagę na takie formy jak sport-terapia, szkolenia zawodowe, młodzieżowy klub wolontariusza, realizowane w ramach projektu „SZANSA - Aktywizacja społeczno-zawodowa młodzieży na Lubelszczyźnie”.
\end{abstract}

Słowa kluczowe: nieletni, demoralizacja, ośrodek kuratorski, formy pomocy.

* Sylwia Huczuk - magister Pedagogiki Resocjalizacyjnej Uniwersytetu Marii Curie-Skłodowskiej w Lublinie. Absolwentka Studium Przeciwdziałania Przemocy w Rodzinie na IPZ w Warszawie. Aktualnie pracuje jako wychowawca w ośrodku kuratorskim w Lublinie, pełni funkcję Społecznego Kuratora Sądowego przy Sądzie Rejonowym Lublin-Zachód w Lublinie. Ponadto - członek zespołu realizującego projekt „Szansa - Aktywizacja społeczno-zawodowa młodzieży na Lubelszczyźnie” oraz „NOWA DROGA” dla osób opuszczających jednostki penitencjarne. Zainteresowania naukowe to resocjalizacja nieletnich $\mathrm{w}$ warunkach wolnościowych oraz resocjalizacja osób dorosłych w zakładach karnych i aresztach śledczych. 


\section{Wstęp}

Uchylanie się od obowiązku szkolnego, wagary, nieposłuszeństwo, wprowadzanie się w stan odurzenia czy dokonywanie czynów karalnych to najczęściej przejawiane symptomy demoralizacji wśród młodzieży. Coraz częściej obserwuje się sytuacje, w których młodzież jest niedopilnowana, pozbawiona kontroli, a sama ma trudności z dostosowaniem się do panujących zasad. Ponadto młodzi ludzie nie radzą sobie w sytuacjach trudnych, nie potrafią panować nad własnymi emocjami, często reagują złością, agresją, mają trudność z wykonaniem podstawowych czynności, takich jak np. sprzątanie. Oprócz tego osoby nieletnie charakteryzuje niski poziom samooceny i poczucia własnej wartości, brak aspiracji i planów na przyszłość, bierność życiowa, brak empatii.

Sąd, decydując o losach młodego człowieka, może zastosować względem niego środek poprawczy bądź środki wychowawcze. Jednym ze środków wychowawczych jest umieszczenie w ośrodku kuratorskim, placówce resocjalizacyjnej o charakterze otwartym. Pobyt w nim daje nieletnim szansę do poprawy własnego zachowania, kształtowania kompetencji społecznych, nauki czynności porządkowych, uzyskania kwalifikacji zawodowych oraz pracy na rzecz osób potrzebujących. Pobyt nieletnich w placówce resocjalizacyjnej typu otwartego ma wpływ na ich życie społeczne, edukację oraz podjęcie przez nich w przyszłości zatrudnienia.

Ważne z punktu widzenia wychowawczo-pedagogicznego jest odpowiednie wsparcie udzielane nieletnim podczas ich pobytu w ośrodku kuratorskim. Zapewnienie podopiecznym poczucia bezpieczeństwa, akceptacji, okazanie zainteresowania, stawianie granic i mobilizowanie do aktywnego udziału w formach wsparcia mogą przyczynić się do wzrostu efektywności prowadzonych oddziaływań wychowawczo-resocjalizacyjnych. Tym samym mogą wpłynąć na obniżenie poziomu demoralizacji nieletnich oraz ryzyka występowania zachowań przestępczych w przyszłości.

W niniejszym artykule dokonana zostanie analiza poszczególnych form wsparcia świadczonych na rzecz nieletnich w ośrodkach kuratorskich. Wskazane zostają odpowiednie metody i formy pracy, korzystnie wpływające na rozwój podopiecznych, jak również przyczyniające się do zmniejszenia ryzyka pogłębiania się procesu ich demoralizacji.

\section{Ośrodek kuratorski jako jeden ze środków wychowawczych stosowanych względem nieletnich}

Jednym ze środków wychowawczych stosowanych względem osób nieletnich zgodnie z UPN jest ośrodek kuratorski, placówka o charakterze otwartym, prowadzona głównie w miejscu zamieszkania podopiecznych. Placówki te tworzone są przy sądach rejonowych w zależności od potrzeb lokalnych, liczby spraw nieletnich oraz 
stopnia ich demoralizacji ${ }^{1}$. Decyzję o utworzeniu lub zniesieniu ośrodka kuratorskiego podejmuje prezes sądu okręgowego na wniosek prezesa sądu rejonowego oraz po zasięgnięciu opinii kuratora okręgowego ${ }^{2}$. Jak wskazuje art. 3. UPN, wszelkie zajęcia z podopiecznymi odbywają się w ośrodku kuratorskim, jednak w sytuacji, gdy przemawiają za tym względy organizacyjne lub wychowawcze, mogą odbywać się poza jego siedzibą ${ }^{3}$.

Do ośrodka kuratorskiego na podstawie orzeczeń sądowych kierowane są osoby, znajdujące się w wieku do 18 lat, które wykazują symptomy demoralizacji lub dopuściły się czynu karalnego ${ }^{4}$. Ustawa o postępowaniu w sprawach nieletnich dokonuje klasyfikacji nieletnich na trzy kategorie ${ }^{5}$ :

- osoby do 18 roku życia, wobec których podejmuje się działania mające na celu zapobieganie i zwalczanie demoralizacji;

- osoby, które między 13 a 17 rokiem życia popełniły czyn karalny;

- osoby, wobec których sąd zastosował środki wychowawcze lub poprawcze maksymalnie do 21 roku życia.

Warto w tym miejscu dodać, że sąd rodzinny, orzekając środki wychowawcze (w tym ośrodek kuratorski), bierze pod uwagę: stopień demoralizacji nieletniego, charakter popełnionego przez niego czynu oraz motywy jego postępowania, a także czynniki wychowawcze, resocjalizacyjne i opiekuńcze ${ }^{6}$.

Obowiązujące akty prawne nie podają ścisłej definicji demoralizacji, jednak określają szczegółowy katalog jej symptomów, do których należą: naruszanie zasad współżycia społecznego, popełnienie czynu zabronionego, systematyczne uchylanie się od obowiązku szkolnego lub kształcenia zawodowego, używanie alkoholu lub innych substancji odurzających w celu wprowadzenia się w stan odurzenia, uprawianie nierządu, włóczęgostwo, udział w grupach przestępczych ${ }^{7}$.

W literaturze demoralizacja jest traktowana jako odrzucenie lub nieprzestrzeganie przez osoby nieletnie norm moralnych oraz prawnych, co negatywnie oddziałuje na wypełnianie przez nie ról społecznych, podporządkowanie się wymogom stawianym przez rodzinę, szkołę czy miejsce pracy $^{8}$. W procesie demoralizacji dochodzi do przewartościowania posiadanych wartości na te, do których najczęściej człowiek

${ }^{1}$ Rozporządzenie Ministra Sprawiedliwości z dnia 5 października 2001 r. w sprawie ośrodków kuratorskich [Dz. U. z 2001 nr 120 poz. 1294 art. $3 \$ 1$ 1].

${ }^{2}$ Ustawa o postępowaniu w sprawach nieletnich z dnia 26 października 1982 [Dz. U. z 1982 nr 35 poz. 228 art. $4 \$ 1]$.

3 Tamże, art. 3.

${ }_{4}$ Tamże, art. 2.

5 Tamże, art. $1 \S 1$.

6 Tamże, art. $3 \$ 1$ i 2.

7 Ustawa o postępowaniu w sprawach nieletnich z dnia 26 października 1982 [Dz.U. z 1982 nr 35 poz. 228 art. $4 \$ 1]$.

${ }^{8}$ A. Strzembosz., System sq̨dowych środków ochrony dzieci i młodzieży przed niedostosowaniem społecznym, Wydawnictwo KUL, Lublin 1985, s. 129. 


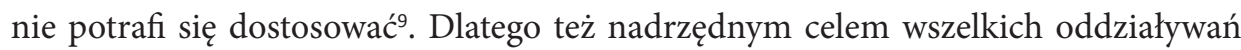
prowadzonych wobec nieletnich jest uzyskanie zmian w postawie uczestników w kierunku społecznie pożądanym, zapewniającym prawidłowy rozwój ich osobowości, poprzez:

zaspokajanie potrzeb osobowościowych, rozwiązywanie problemów psychicznych, uczenie samodzielnego radzenia sobie z trudnościami życiowymi, eliminowanie zaniedbań wychowawczych i edukacyjnych oraz wyrównywanie zaniedbań środowiskowych. Ponadto wdrażanie do przestrzegania norm społecznych, rozwijanie zainteresowań, wyrabianie właściwych nawyków spędzania czasu wolnego, rozładowywanie napięć emocjonalnych, kształtowanie poczucia odpowiedzialności i opiekuńczości ${ }^{10}$.

\section{Formy pomocy udzielanej nieletnim - podopiecznym ośrodków kuratorskich}

Nieletni podopieczni ośrodków kuratorskich to najczęściej osoby pochodzące z rodzin niepełnych, dysfunkcyjnych, w których istniał problem alkoholowy bądź inne uzależnienia, a także bezrobocie obojga lub jednego z rodziców. Dodatkowo często w rodzinach pojawiały się takie czynniki jak: przemoc, akty przestępcze, brak dostatecznej opieki, kontroli, zainteresowania względem dzieci, stosowanie nieodpowiednich metod wychowawczych (np. nadmierne karanie czy nagradzanie), częsta zmiana miejsca zamieszkania lub partnerów przez rodziców nieletnich ${ }^{11}$. Wyżej wymienione czynniki mają negatywny wpływ na prawidłowy proces socjalizacji młodego człowieka, mogą stać się przyczyną wykształcenia niedojrzałości społecznej, bierności życiowej, braku aspiracji i planów na przyszłość, jak również wystąpienia u nieletnich trudności w nawiązywaniu relacji interpersonalnych, obniżenia poziomu ich samooceny oraz poczucia własnej wartości ${ }^{12}$. W konsekwencji może to doprowadzić do łamania przez nieletnich obowiązujących norm prawnych, przejawiania symptomów demoralizacji, dokonywania przestępstw lub poszukiwania innych niż rodzina grup odniesienia w celu zrekompensowania sobie braków, tj. poczucia bezpieczeństwa, potrzeby akceptacji. Dlatego też wszelkie oddziaływania prowadzone względem nieletnich powinny zapewnić im poczucie bezpieczeństwa, atmosferę zaufania, a oprócz tego wpływać na poprawę ich zachowania, respektowania przez nich norm prawnych. Istotna jest również praca, mająca na celu wzrost poziomu poczucia

\footnotetext{
9 Cz. Czapow, Wychowanie resocjalizujące, PWN, Warszawa 1978, s. 140-141.

10 Rozporządzenie Ministra Sprawiedliwości z dnia 5 października 2001 r. w sprawie ośrodków kuratorskich [Dz. U. z 2001 nr 120 poz. 1294 art. 5. ust. 1].

11 Por.: Cz. Cekiera, Zagrożenia dzieci i młodzieży w środowisku szkolnym i pozaszkolnym, Wydawnictwo Adam Marszałek, Gdańsk-Toruń 1995, s. 62.

12 B. Hołyst, Kryminologia, PWN, Warszawa 2001, s. 450.
} 
własnej wartości, samooceny, aspiracji życiowych, rozwijania zainteresowań, nabycia niezbędnych kompetencji społecznych oraz poprawę relacji interpersonalnych.

Zgodnie z UPN ośrodek kuratorski prowadzi działalność profilaktyczną, opiekuńczo-wychowawczą, resocjalizacyjno-terapeutyczną, zmierzającą do zmiany postaw uczestników ${ }^{13}$. Zajęcia odbywające się w siedzibie ośrodka polegają głównie na organizacji czasu wolnego, udzielaniu pomocy edukacyjno-wychowawczej przez pedagogów oraz korepetytorów, w celu usunięcia powstałych zaniedbań oraz nawiązania współpracy ze środowiskiem ${ }^{14}$. Ośrodek kuratorski zapewnia podopiecznym wsparcie psychologiczne, czyli indywidualne rozmowy z psychologiem bądź zajęcia grupowe ukierunkowane na rozwijanie kompetencji społecznych, radzenie sobie z trudnościami życiowymi oraz rozwiązywanie bieżących problemów ${ }^{15}$.

Warto w tym miejscu wspomnieć, że oprócz podstawowych form wsparcia, dużą szansę dla nieletnich stanowi udział w projekcie: ,SZANSA - Aktywizacja społeczno-zawodowa młodzieży na Lubelszczyźnie" realizowanym przez Stowarzyszenie POSTIS w Lublinie. Projekt ten obejmuje swoim zasięgiem ośrodki kuratorskie w województwie Lubelskim, zapewniając uczestnikom w wieku od 15 do 17 lat dodatkowe wsparcie w postaci: doradztwa zawodowego, warsztatów psychospołecznych, profilaktycznych, szkoleń zawodowych oraz udziału w młodzieżowym klubie wolontariusza. Te formy wsparcia są niezbędne dla nieletnich, ponieważ ukierunkowane są na wzrost poziomu aktywności społecznej, przejawiania własnej inicjatywy, a także świadczenie pomocy osobom potrzebującym i nabycie kompetencji psychospołecznych. Udział w młodzieżowym klubie wolontariusza oraz praca wykonywania na rzecz innych mogą przyczynić się do zmiany postaw społeczeństwa względem nieletnich z ośrodka kuratorskiego.

$\mathrm{Na}$ potrzeby niniejszego artykułu dokonana została analiza dodatkowych form wsparcia udzielanych dla nieletnich - podopiecznych ośrodków kuratorskich w ramach realizacji projektu SZANSA. Stanowią one dopełnienie podstawowej pomocy dla podopiecznych w ośrodku kuratorskim i są istotne z punktu widzenia pracy resocjalizacyjno-wychowawczej.

Pierwszą formę wsparcia stanowi doradztwo zawodowe, które obejmuje diagnozę posiadanych kompetencji i umiejętności społecznych oraz preferencji zawodowych nieletnich. Celem spotkań z doradcą zawodowym jest stworzenie podopiecznym indywidualnego planu działania, przygotowania ich do trafnego wyboru zawodu oraz przekazania im wiedzy niezbędnej do zaplanowania własnej kariery zawodowej. Oprócz tego udział w doradztwie zawodowym zapewnia uczestnikom nabycie umie-

${ }^{13}$ Ustawa o postępowaniu w sprawach nieletnich z dnia 26 października 1982 [Dz.U. z 2016 poz. 165 art. 5. ust. 1].

14 Tamże, art. $7 \$ 2$.

15 Rozporządzenie Ministra Sprawiedliwości z dnia 5 października 2001 r. w sprawie ośrodków kuratorskich [Dz.U. z 2001 nr 120 poz. 1294]. 
jętności w zakresie sporządzania dokumentów aplikacyjnych, autoprezentacji podczas rozmów kwalifikacyjnych oraz nabycia kwalifikacji zawodowych ${ }^{16}$.

Druga forma wsparcia to warsztaty kompetencji psychospołecznych, ukierunkowane na kształtowanie i nabywanie przez uczestników umiejętności społecznych, radzenia sobie ze stresem, rozwiązywania konfliktów itd. Warsztaty skupiają się na nauce współpracy i współdziałania, tolerancji i akceptacji, kształtowaniu umiejętności podejmowania samodzielnych decyzji, a także udzielaniu nieletnim pomocy w rozwiązywaniu problemów.

Trzecia forma wsparcia to warsztaty socjoterapii, których głównym celem jest:

stworzenie uczestnikom warunków do zaistnienia procesu korekcji swojego postępowania, poprzez działania wpływające na przebudowę negatywnych sądów poznawczych o sobie i innych, przeżycie emocjonalnego korektywnego doświadczenia będącego alternatywą dla wcześniej przeżywanych urazów, wypróbowanie nowych efektywnych wzorców zachowań ${ }^{17}$.

Socjoterapia jest istotna w pracy resocjalizacyjno-wychowawczej ze względu na to, że stanowi ona formę pomocy psychologicznej skierowanej do osób znajdujących się w grupie ryzyka lub przejawiających zaburzenia w zachowaniu. Umożliwia nabycie nowych doświadczeń interpersonalnych, które są przeciwstawne do przykrych, wcześniej doznawanych ${ }^{18}$. W ramach zajęć socjoterapeutycznych uczestnicy mogą uczestniczyć w treningu relaksacyjnym, którego celem jest wywołanie u uczestników stanu odprężenia, wewnętrznego spokoju, radości, odczuwania pozytywnych emocji $^{19}$. W przypadku osób nieletnich relaksacja okazuje się potrzebna ze względu na to, że bardzo często nie potrafią one radzić sobie ze złością i panować nad własnymi emocjami.

Projekt SZANSA zapewnia również uczestnikom udział w warsztatach $\mathrm{z}$ arteterapii - terapii poprzez sztukę (rysunek, malarstwo, rzeźbę, grafikę, collage), której nadrzędnym celem jest oddziaływanie na osobowość człowieka, głównie jego sferę emocjonalną, przeżywanie pozytywnych emocji, eliminowanie blokad poprzez lecznicze i terapeutyczne elementy różnorodnych dziedzin sztuki²0.

Podopieczni ośrodków kuratorskich mają także możliwość uczestnictwa w zajęciach ze sport-terapii w następujących miejscach: basen, siłownia, sala gimnastyczna.

${ }^{16}$ B. Bojko-Kulpa, „SZANSA - Aktywizacja społeczno-zawodowa młodzieży trudnej” Projekt dla ośrodków kuratorskich, [w:] K. Stasiak i in. (red.), Dziewięćdziesięciolecie kurateli sądowej w Polsce. Historia - Teraźniejszość - Przyszłość, Wydawnictwo Impuls, Kraków 2010.

${ }^{17}$ J. Jagieła, Socjoterapia w szkole. Krótki poradnik psychologiczny, Wydawnictwo Rubikon, Kraków 2007, s. 9-10.

${ }^{18}$ K. Sawicka, Socjoterapia - model myślenia o psychokorekcji cz. II, „Remedium”, nr 3/2004, s. 18.

19 S. Siek, Treningi relaksacyjne, Warszawa 1990, s. 5.

${ }^{20}$ E. Galińska, Podstawy teoretyczne muzykoterapii, „Zeszyt naukowy Akademii Muzycznej we Wrocławiu", nr 17/1978, s. 84. 
Celem zajęć jest przede wszystkim odreagowanie stresu w pozytywny sposób, wyładowanie napięć, przejawianie aktywności fizycznej.

W ramach projektu SZANSA podopieczni mogą uczestniczyć w zajęciach z zakresu profilaktyki uzależnień i edukacji prozdrowotnej. Służą one promowaniu zdrowego trybu życia (w tym aktywnego wypoczynku, prawidłowego i zdrowego odżywiania), jak również wyposażeniu podopiecznych w wiedzę dotycząca udzielania pierwszej pomocy, wzmacniania zasobów własnych oraz wspólnego rozwiązywania problemów.

Poza zajęciami tematycznymi i warsztatami nieletni z ośrodków kuratorskich uczestniczą w młodzieżowym klubie wolontariusza. Czynne uczestnictwo w klubie, oprócz umożliwiania zdobycia niezbędnej wiedzy na temat przyjmowania odpowiednich postaw społecznych i zaangażowania społecznego, kształtuje świadomość nieletnich w zakresie wartości idei wolontariatu. Młodzi ludzie maja możliwość poznania pracy wolontariusza w praktyce, uczestnictwa w szkoleniach oraz samodzielnego przygotowywania różnych inicjatyw o charakterze pomocowym. Tworzenie przez nieletnich eventów skierowanych do środowisk wymagających wsparcia, np. osób starszych, niepełnosprawnych itp., stwarza możliwość dzielenia się swoimi zainteresowaniami i pasjami. Umożliwia jednocześnie podejmowanie pracy na rzecz innych, kształtowanie postawy altruistycznej, a w rezultacie może przyczynić się do zmiany postrzegania osób nieletnich - podopiecznych ośrodka kuratorskiego - przez społeczeństwo.

\section{Zakończenie}

Podopieczni ośrodka kuratorskiego to osoby pochodzące najczęściej z rodzin dysfunkcyjnych, obarczonych problemem alkoholowym bądź innymi uzależnieniami, bezrobociem, brakiem aspiracji i perspektyw życiowych. Nieletni, wychowując się $\mathrm{w}$ takich środowiskach, nie wynoszą z domu poszanowania podstawowych wartości, jak rodzina, dobro, miłość, zdrowie czy piękno. Osoby młode, pozbawione odpowiedniej opieki czy kontroli ze strony rodziców, odczuwające brak bezpieczeństwa, wsparcia, miłości, najczęściej szukają akceptacji w grupach rówieśniczych, często destrukcyjnych, w których chcą zrekompensować sobie braki wyniesione $\mathrm{z}$ domu.

Coraz częściej zdarzają się sytuacje, kiedy nieletni trafiają do grup, w których ze względu na chęć zaistnienia, zwrócenia na siebie uwagi czy też przypodobania się innym dokonują czynów niezgodnych z prawem. Początkiem zazwyczaj stają się wagary, nieposłuszeństwo, pierwszy kontakt z używkami, natomiast rezultatem może być dokonanie czynu karalnego, a konsekwencją umieszczenie w placówce wychowawczej typu zamkniętego.

Dlatego też nieletni, wobec których sąd rodzinny orzekł środek wychowawczy w postaci ośrodka kuratorskiego, podczas pobytu w placówce powinni mieć przede wszystkim zapewnione poczucie bezpieczeństwa, być otoczeni opieką i wsparciem 
oraz kontrolą ze strony wychowawców czy innych pracowników. Oprócz tego niezbędny jest ich udział we wszystkich formach wsparcia oraz praca nad sobą.

Korzystanie ze świadczeń zapewnianych przez ośrodki kuratorskie, takich jak: doradztwo zawodowe, edukacyjne, psychospołeczne, profilaktyczne, szkolenia zawodowe oraz uczestnictwo w młodzieżowym klubie wolontariusza, stanowi dla nieletnich szansę na poprawę życia, wzrost poziomu ich aktywności społecznej, przejawiania własnej inicjatywy, samodzielnego niesienia pomocy osobom potrzebującym oraz obniżenie poziomu ryzyka wystąpienia kolejnych przejawów demoralizacji. Praca ochotnicza w młodzieżowym klubie wolontariusza może przyczynić się do zmiany postaw innych ludzi względem nieletnich z ośrodka kuratorskiego, jak również do wzrostu poziomu zaangażowania młodzieży z ośrodków w działania o charakterze pomocowym.

\section{Bibliografia}

Bojko-Kulpa B., „SZANSA - Aktywizacja społeczno-zawodowa młodzieży trudnej”. Projekt dla ośrodków kuratorskich, [w:] K. Stasiak, Ł. Wirkus, P. Kozłowski, T. Jedynak (red.), Dziewięćdziesięciolecie kurateli sądowej w Polsce. Historia Teraźniejszość - Przyszłość, Wydawnictwo Impuls, Kraków 2010, s. 383-393.

Cekiera Cz., Zagrożenia dzieci i młodzieży w środowisku szkolnym i pozaszkolnym, Wydawnictwo Adam Marszałek, Gdańsk - Toruń 1995.

Czapow Cz., Wychowanie resocjalizujące, PWN, Warszawa 1978.

Galińska E., Podstawy teoretyczne muzykoterapii, „Zeszyt naukowy Akademii Muzycznej we Wrocławiu”, nr 17/1978, s. 81-98.

Hołyst B., Kryminologia, PWN, Warszawa 2001.

Jagieła J., Socjoterapia w szkole. Krótki poradnik psychologiczny, Wydawnictwo Rubikon, Kraków 2007.

Rozporządzenie Ministra Sprawiedliwości z dnia 5 października 2001 r. w sprawie ośrodków kuratorskich [Dz. U. z 20011206 poz. 1294 art. 3\$ 1].

Sawicka K., Socjoterapia - model myślenia o psychokorekcji cz. II, „Remedium”, nr 3/ 2004, s. 18-19.

Siek S., Treningi relaksacyjne, ATK, Warszawa 1990.

Strzembosz A., System sądowych środków ochrony dzieci i młodzieży przed niedostosowaniem społecznym, Wydawnictwo KUL, Lublin 1985.

Ustawa o postępowaniu w sprawach nieletnich z dnia 26 października 1982 [Dz.U. z 1982 nr 35 poz. 228]. 


\section{Forms of assistance given to minors - the ward of the curator's center}

Abstract: Juveniles in the care of probation centers are individuals displaying symptoms of demoralization in the form of e.g. truancy, evading compulsory education, abusing intoxicating substances such as drugs or alcohol, vagrancy, practicing prostitution, committing forbidden acts, participating in criminal groups, violating rules of social coexistence. Juveniles are referred to such an institution based on a legally valid ruling of a Family Court; individuals in the care of probation centers are aged 13 to 17. Persons who have been adjudicated an education measure in the form of placement in a probation centre most commonly come from dysfunctional families, in which there was violence; addiction of one or both of the parents; unemployment; a lack of love, sense of security, interest from a parent. The abovementioned factors contribute to forming in children a low self-esteem, self-assessment, passivity, lead to a law-violating life. That is why the assistance provided to minors during their stay in a probation center is so essential. The forms of support for demoralized youth staying in a probation centre include: psychological and pedagogical counselling, workshops on developing social competences, preventative activities, relaxation training. Additionally, sports therapy, job training, a youth volunteer club operating as part of "Chance - Social and Vocational Activation of Young People".

Keywords: Minors, demoralization, curator's center, forms of assistance

\footnotetext{
About the author: Sylwia Huczuk - Master of Arts in Social Rehabilitation at Maria Skłodowska-Curie University in Lublin. A graduate of the Department of Family Violence Prevention at the Institute of Health Psychology in Warsaw. Currently working as a tutor in a social care and rehabilitation facility in Lublin, she serves as a Social Probation Officer at the Lublin-West District Court. Additionally, a member of the team conducting the projects: "Chance - Social Activation of Young People in the Lublin Region" for probation centers and the "NEW PATH" for individuals discharged from penitentiary units.
} 


\title{
Karolina Mendecka*
}

Uniwersytet Łódzki

mendecka.k@gmail.com

\section{Niwelowanie szczególnie trudnej sytuacji dziecka w perspektywie intersekcjonalnej}

\begin{abstract}
Streszczenie: Artykuł ma na celu omówienie teorii przecięć jako metody na wzmocnienie praw dziecka poprzez uwzględnienie perspektywy intersekcjonalnej, zarówno na arenie międzynarodowej, jak i w wymiarze krajowym. Sytuacja dzieci przynależących do wielu kategorii społecznych pozostaje niezauważona przez ustawodawcę, sądy, władzę administracyjną, a także publiczne oraz prywatne instytucje opieki społecznej, które koncentrują się na jednym aspekcie (np. niepełnosprawności), nie dostrzegając krzyżujących się dalszych cech (np. płeć i pochodzenie). Tymczasem cechy te powinny być brane pod uwagę jednocześnie i całościowo, ponieważ są ze sobą nierozerwalnie sprzężone. Niezbywalne i przyrodzone prawa dziecka w obecnym kształcie wymagają podjęcia próby ponownego ich określenia w aspekcie analizy intersekcjonalnej w celu przywrócenia faktycznej równości szans w ich wykorzystaniu.
\end{abstract}

Słowa kluczowe: intersekcjonalizm, dyskryminacja, dyskryminacja wielowymiarowa, dobro dziecka, prawa dziecka.

\section{Wprowadzenie}

Rozwój nauk społecznych wpływa na interpretacje praw człowieka, szczególnie odkąd w literaturze zaczęto podkreślać, że czynniki, takie jak niepełnosprawność, rasa inna niż biała, pochodzenie etniczne oraz płeć żeńska w dużym stopniu przyczyniają się do pogłębiania dyskryminacji jednostek i grup. Znalazło to odbicie w szczegółowych aktach międzynarodowych: począwszy od Międzynarodowej kon-

* Karolina Mendecka - jest doktorantką w katedrze Teorii i Filozofii Prawa na Wydziale Prawa i Administracji Uniwersytetu Łódzkiego. Ponadto studiuje Prawa Człowieka i Prawo Humanitarne na Uniwersytecie w Lund i w Instytucie R. Wallenberga. Do zainteresowań badawczych należą w głównej mierze prawa człowieka, prawa dziecka, gender studies, klauzule generalne w prawie międzynarodowym. 
wencji w sprawie likwidacji wszelkich form dyskryminacji rasowej z 1965 r. (CERD) ${ }^{1}$, przez Konwencję w sprawie likwidacji wszelkich form dyskryminacji kobiet z $1979 \mathrm{r}$. $(\mathrm{CEDAW})^{2}$, aż do stosunkowo niedawno ogłoszonej Konwencji o prawach osób niepełnosprawnych z 2006 r. (CRPD)3. Mimo że dyskryminacja była wyraźnie zakazana we wcześniejszych konwencjach praw człowieka (m.in. w Międzynarodowym Pakcie Praw Obywatelskich i Politycznych (ICCPR) ${ }^{4}$ oraz Międzynarodowym Pakcie Praw Gospodarczych, Społecznych i Kulturalnych (ICESCR) ${ }^{5}$, dostrzeżono potrzebę odrębnej regulacji sytuacji osób należących do takich kategorii społecznych, które są historycznie oraz systemowo narażone na dyskryminacje i nierówne traktowanie. Niewykluczone, że w najbliższych latach uchwalone zostaną kolejne dokumenty, skierowane na ochronę społeczności LGBTQ ${ }^{6}$ czy też osób starszych ${ }^{7}$. Jednakże, pomimo znaczących postępów w rozwoju koncepcji i interpretacji zasady niedyskryminacji, wiele osób wciąż pozostaje poza zasięgiem ochrony ustawowej oraz programów pomocowych. Jedną z możliwych przyczyn takiego stanu rzeczy jest być może intersekcjonalność, czyli krzyżowanie się ze sobą różnych kategorii społecznych. Koncepcja intersekcjonalności, którą w literaturze nazywa się również teorią przecięć (od ang. intersect - 'przeciąć się, krzyżować') ${ }^{8}$, ma na celu wskazanie zależności pomiędzy przynależnością do różnych kategorii społecznych (dwóch lub więcej). Niniejsza praca skupia się na omówieniu tej teorii i wskazaniu na jej potencjalny wpływ na poprawę trudnej sytuacji dziecka. Wiek jest również jedną z kategorii społecznych, która może wpływać na wykluczenie (dzieci oraz osób starszych) z dyskursu społeczno-politycznego. W przypadku nałożenia się dodatkowych czynników, takich jak niepełnosprawność, pochodzenie etniczne czy płeć, sytuacja takich dzieci może pozostać niedostrzeżona przez ustawodawcę, pracowników społecznych czy nawet nauczycieli. Zwrócenie uwagi na krzyżowanie się tych czynników zmienia perspektywę oraz ukierunkowuje na potrzeby jednostki, tym samym eliminując zbędny esencjalizm 9 Najważniejszym celem poniższej analizy jest zwrócenie uwagi na konieczność implementacji intersekcjonalnej perspektywy nie tylko przez ustawodawcę, ale przede wszystkim przez organy stosujące prawo poprzez odpowiednią wykładnię oraz tych

1 Dz. U. z 1969 r. Nr 25, poz. 187.

2 Dz. U. z 1982 r. Nr 10, poz. 71.

${ }^{3}$ Dz. U. z 2012 poz. 1169.

${ }^{4}$ Dz. U. 1977 nr 38 poz. 167.

5 Dz. U. 1977 nr 38 poz. 169.

${ }^{6}$ Ang. 'lesbian, gay, bisexual, transqender, queer', zob.: T. Mayes, Understanding Intersectionality between the Law, Gender, Sexuality and Children, „Children's Legal Rights Journal“, nr 26/2016, s. 90.

${ }^{7}$ Zob.: A. Bruce, Which Entitlements and for Whom? The Convention on the Rights of Persons with Disabilities and its Ideological Antecedents, Lund 2014.

8 Zob. M. Boryczko i inni, Przeciw biedzie. Socjologiczno-pedagogiczny przyczynek do nowych rozwiązań starego problemu, Gdańsk 2016.

9 R. Kapur, The Tragedy of Victimization Rhetoric: Resurrecting the "Native” Subject in Internaional/Post-Colonial Feminist Legal Politics, „Harvard Human Rights Journal”, nr 15/2002, s. 2. 
wszystkich, którzy mają wpływ na sytuację dzieci, ze szczególnym uwzględnieniem pracowników społecznych, socjalnych oraz nauczycieli i wychowawców.

\section{Intersekcjonalność - geneza i znaczenie}

Pojęcie intersekcjonalności (ang. intersectionality) zostało rozpowszechnione przez Kimberlé Crenshaw, czarnoskórą profesor prawa, w latach 80. Zauważyła ona, że ruch praw kobiet pomijał w swoich analizach kobiety czarnoskóre, a krytyczne studia nad rasą (Critical Race Studies) pomijały z kolei aspekt genderowy. Często w swoich rozważaniach Crenshaw posługuje się sprawą DeGraffenreid v General Motors ${ }^{10}$ aby wyjaśnić teorię przecięć i jej znaczenie. Na tym przykładzie pokazuje, że w branży motoryzacyjnej nie było miejsca zatrudnienia dla kobiet poza recepcją, a dla osób czarnoskórych - poza pracą na zapleczu. Oznaczało to, że dla kobiet czarnoskórych nie istniała w ogóle szansa na zatrudnienie w tym sektorze. Crenshaw podkreśliła, że taka intersekcjonalna subordynacja była (i wciąż pozostaje) często niezauważona, z uwagi na fakt, że rasizm jest odnoszony wyłącznie w relacji do mężczyzn innych niż białych, a seksizm - wyłącznie w odniesieniu do białych kobiet ${ }^{11}$.

Koncepcja interekcjonalizmu może służyć zarówno jako rama teoretyczna i metodologiczna, jak i narzędzie analizy obszarów wykluczenia z uwagi na przynależność do danych kategorii społecznych. Teoria przecięć umożliwia przezwyciężenie niektórych ograniczeń w naukach społecznych, takich jak brak aparatury badawczej, który umożliwiałby dogłębną analizę nierówności społecznych oraz procesów dyskryminacyjnych i wykluczeniowych ${ }^{12}$. Dzięki poszerzeniu obszarów analitycznych o dodatkowe kategorie, takie jak niepełnosprawność, wiek, status materialny itd., oraz uwzględnieniu współdziałania tych parametrów (i ich wzajemnego krzyżowania się), te nieadekwatności badawcze mogą być znacząco zmniejszone ${ }^{13}$. Sukces analizy intersekcjonalnej zależy jednak od zmian legislacyjnych, uwzględniających doświadczenia mniejszościowe oraz zmierzających do wyrównania szans grupom dyskryminowanym.

10 DeGraffenreid v General Motors Assembly Division, United States Court of Appeals, Eight Circuit, 558 F.2d 480.

11 K. Crenshaw, P. Schulz, Intersectionality in Promoting Equality, „The Equal Rights Review“, nr 16/2016, s. 210.

12 E. Oleksy, Teoria i praktyka intersekcjonalności w nauczaniu akademickim, [w:] T. Domański (red.), Międzynarodowe studia polityczne i kulturowe wobec wyzwań współczesności, Łódź 2015, s. 42.

13 Tamże. 


\section{Dyskryminacja i intersekcjonalność}

Dyskryminacja oznacza odmienne traktowanie osób znajdujących się w podobnej sytuacji przy braku obiektywnego, rozsądnego uzasadnienia ${ }^{14}$. Zakaz dyskryminacji jest podkreślony w każdym dokumencie dotyczącym praw człowieka. Przykładowo, art. 26 ICCPR stanowi, że:

wszyscy są równi wobec prawa i są uprzywilejowani do jednakowej ochrony prawnej. Jakakolwiek dyskryminacja w tym zakresie powinna być ustawowo zakazana oraz powinna być zagwarantowana przez ustawę równą dla wszystkich i skuteczną ochroną przed dyskryminacją z takich względów, jak: rasa, kolor skóry, płeć, język, religia, poglądy polityczne lub inne, pochodzenie narodowe lub społeczne, sytuacja majątkowa, urodzenie lub jakiekolwiek inne okoliczności.

W podobny sposób zakaz dyskryminacji ujęty jest w art. 2(2) ICESCR, art. 14 Europejskiej Konwencji Praw Człowieka (ECHR) ${ }^{15}$, art. 1 Amerykańskiej Konwencji Praw Człowieka (ACHR) ${ }^{16}$ oraz w preambule Afrykańskiej Karty Praw Człowieka i Ludów (ACHPR $)^{17}$. Istotny jest jednak fakt, że w żadnym z tych z dokumentów dotyczących praw człowieka, pomimo wytyczenia katalogu cech, które (co do zasady) nie mogą stanowić okoliczności, ze względu na które odmienne traktowanie jest uzasadnione, nie jest dostrzeżony problem dyskryminacji wielokrotnej bądź intersekcjonalnej. W sposób domyślny wielokrotna dyskryminacja została wyszczególniona dopiero w CERD w art. 1, w art. 1 CEDAW oraz w Konwencji o prawach dziecka z 1989 r. $(\mathrm{CRC})^{18} \mathrm{w}$ art. 2 , art. 22 , art. 23 oraz art. 30.

W sposób literalny, dyskryminacja wielokrotna została uwzględniona dopiero $\mathrm{w}$ CDPD $\mathrm{w}$ Preambule, $\mathrm{w}$ podpunkcie (p): the difficult conditions faced by persons with disabilities who are subject to multiple or aggravated forms of discrimination on the basis of race, colour, sex...., co nie zostało jednak odpowiednio i z należytą starannością uwzględnione w polskiej wersji językowej. Tłumaczenie posługuje się sformułowaniem: trudna sytuacją, w jakiej znajduja się osoby niepetnosprawne, wobec których stosuje się często $i w$ dużym zakresie dyskryminację ze względu na ich przynależność rasowa, kolor skóry, płeć... Ponadto, art. 6 Konwencji podkreśla, że women and girls with disabilities are subject to multiple discrimination, co po polsku ujęto: kobiety i dziewczęta niepetnosprawne są przedmiotem różnorodnych form dyskryminacji. Użyte tłumaczenia nie znajdują uzasadnienia, ponieważ wskazują na niezrozumienie koncepcji dyskryminacji zwielokrotnionej przez polskiego ustawodawcę oraz na niedbałość

${ }_{14}$ Zob. Willis przeciwko Zjednoczonemu Królestwu, skarga nr 36042/97 oraz Okpisz przeciwko Niemcom, skarga nr 59140/00.

${ }^{15}$ Dz. U. 1993 nr 61 poz. 284.

16 Zob.: https://bs.sejm.gov.pl/F?func $=$ findb\&request $=000000265 \&$ find code $=$ SYS\&local ba$\underline{\mathrm{se}}=\mathrm{TEK} 01$.

17 Zob.: https://bs.sejm.gov.pl/F?func $=$ findb\&request $=000000235 \&$ find code $=$ SYS\&local ba$\underline{\mathrm{se}=\mathrm{TEK} 01}$.

${ }^{18}$ Dz. U. 1991 nr 120 poz. 526. 
legislacyjną. Wszystko to sugeruje, że w Polsce niewystarczająco dobrze rozwinięta jest koncepcja dyskryminacji wielokrotnej, a w konsekwencji również intersekcjonalności.

Intersekcjonalność jest często utożsamiana $\mathrm{z}$ dyskryminacją wielokrotną, co znajduje odbicie również $\mathrm{w}$ aktach międzynarodowych. Co prawda te dwa pojęcia definiują się wzajemnie, lecz dyskryminacja wielokrotna jest pojęciem szerszym niż intersekcjonalność. Jak zauważa Ben Smith, mimo że oparte są one na podobnych założeniach, wyłącznie koncepcja intersekcjonalnej dyskryminacji w odpowiedni sposób ujmuje doświadczenia intersekcjonalnej tożsamości, czyli współoddziaływania wielu kategorii społecznych ${ }^{19}$. Tożsamość ta składa się z wielu różnorodnych komponentów, które są ze sobą nierozerwalnie sprzężone. Przynależność do różnych kategorii społecznych jednocześnie nie pozwala na wyraźne rozróżnienie pomiędzy doświadczeniem dyskryminacji z uwagi na jakikolwiek czynnik. Zatem należy rozpatrywać intersekcjonalność jako współdziałanie czynników dyskryminacyjnych, a nie jako ich sumę $e^{20}$. Uwzględnienie w sposób całościowy wszystkich obszarów wykluczenia ma na celu wyrównanie szans i, w ostatecznym rozrachunku, osiągnięcie równości materialnej.

\section{Intersekcjonalność i dziecko}

Koncepcja intersekcjonalności, chociaż rozpowszechniona przede wszystkim w dyskursie feministycznym, używana jest obecnie w celu zwrócenia uwagi na różnorakie „przecięcia”: nie tylko pomiędzy rasą a płcią, ale też: pochodzeniem etnicznym, orientacją seksualną, religią, niepełnosprawnością i wiekiem ${ }^{21}$. Wiek jest jedną z najczęściej umacniających dyskryminację kategorii. Jako że to zazwyczaj osoby starsze są dyskryminowane, dzieci i młodzież zazwyczaj pozostają poza analizą intersekcjonalną ${ }^{22}$. Wybrane przykłady mają na celu jedynie zasygnalizowanie szerokiego problemu. Zostaną poruszone wyłącznie kwestie intersekcji dotyczących wieku i płci, pochodzenia, niepełnosprawności oraz przynależności do społeczności LGBTQ. Rozważania te zmierzają do ukazania roli i znaczenia koncepcji intersekcjonalności dla poprawy trudnej sytuacji dzieci: czy to $z$ uwagi na status materialny, stan zdrowia czy inne

19 B. Smith, Intersectional Discrimination and Substantive Equality: A Comparative and Theoretical Perspective, „The Equal Rights Review“, nr 16/2016, s. 74.

${ }^{20}$ K. Crenshaw, Demarginalizing the Intersection of Race and Sex: A Black Feminist Critique of Antidiscrimination Doctrine, Feminist Theory and Antiracist Politics, „University of Chicago Legal Forum", nr 1/1989, s. 139-67.

${ }^{21}$ B. Dill, R. Zambrana, Emerging Intersections: Race, Class and Gender in Theory, Policy and Practice, New Brunswick - New Jersey - Londyn 2009, s. 4.

${ }_{22}$ G. Quinn, Reflections on the Value of Intersectionality and the Development of Non-Discrimination Law, „The Equal Rights Review“, nr 16/2016, s. 64. 
czynniki pogłębiające trudny los, który jednakże można odmienić dzięki uwzględnieniu intersekcjonalnej perspektywy.

\section{Intersekcjonalność - wiek i płeć}

Rozpatrzenia wymaga przede wszystkim pozycja dziewczynek zarówno w kontekście praw kobiet, jak i praw dziecka. Dziewczynki zdają się być pomijane w obu dyskursach, przez co ich potrzeby nie są należycie odzwierciedlone w ustawodawstwie krajowym oraz umowach międzynarodowych. W CEDAW dziewczynki są wyszczególnione wyłącznie w art. 10 (f), który stanowi o potrzebie zmniejszenia liczby uczennic niekończących szkół oraz organizowania programów dla dziewcząt $i$ kobiet, które zaprzestały nauki. W Konwencji podkreślana jest konieczność zapewnienia równości kobiet i mężczyzn, natomiast kwestia równości dziewczynek pozostaje poza tą regulacją. Te braki są częściowo uzupełniane przez Komitet ds. Likwidacji Dyskryminacji Kobiet, który wyraża potrzebę uwzględniania praw dziewczynek w rekomendacjach oraz uwagach dotyczących sprawozdań z wykonania Konwencji. Szczególną uwagę Komitet poświęca edukacji na temat zdrowia seksualnego i dostępu do ochrony zdrowia ${ }^{23}$. W Polsce szczególnie alarmującą regulacją jest konieczność wyrażenia zgody na udzielenie świadczenia zdrowotnego przez opiekunów prawnych lub faktycznych przed ukończeniem lat $16 \mathrm{w}$ świetle Ustawy o zawodach lekarza i lekarza dentysty $^{24}$ oraz Ustawy o prawach pacjenta i Rzeczniku Praw Pacjenta ${ }^{25}$. Tymczasem ustawodawca przyjął wiek 15 lat jako granicę zgody na kontakty seksualne. W efekcie piętnastolatki pozostawione są możliwości decydowania o swoim zdrowiu reprodukcyjnym. Przeszkody prawne uderzają przede wszystkim w sytuację dziewcząt, które bez zgody rodzica nie mają dostępu do konsultacji ginekologicznej, zatem również antykoncepcji - także tej awaryjnej. Jest to przejaw dyskryminacji z uwagi na zbieg wieku oraz płci, który powinien być zniwelowany przez ustawodawcę ${ }^{26}$.

Podobnie CRC niedostatecznie uwzględnia w tekście prawa dziewczynek. Z wyjątkiem art. 2, który zakazuje dyskryminacji z uwagi na płeć, Konwencja nie wyszczególnia praw dziewczynek, pomimo tego, że są one niewątpliwie w znacznie większym stopniu narażone na łamanie ich praw. Również i w tym wypadku Komitet Praw Dziecka (KPD) zwraca uwagę na szczególnie trudną sytuację dziewczynek, jednak niewiążący charakter uwag KPD sprawia, że tylko w niewielkim stopniu przyczyniają się do rzeczywistej poprawy standardu międzynarodowej i krajowej ochrony ich praw. KPD, w Uwagach końcowych do połączonego trzeciego i czwartego sprawozda-

\footnotetext{
23 Zob.: CEDAW/C/POL/CO/7-8.

24 Dz. U. 2016 poz. 1070.

25 Dz. U. 2009 nr 52 poz. 417.

26 G. Quinn, dz. cyt., s. 70.
} 
nia Polski ${ }^{27}$, zwrócił uwagę przede wszystkim na swobodny dostęp do usług w zakresie zdrowia seksualnego dla dziewczynek oraz na

surowe wymogi prawne dotyczące przerywania ciąży oraz brak jasnej procedury przeprowadzenia legalnego przerywania ciąży zgodnie z obowiązującym prawem, wraz ze społeczną stygmatyzacją, utrudniają dziewczynkom dostęp do zgodnego z prawem przerywania ciąży ${ }^{28}$.

KPD zwraca uwagę na to, że polskie prawo dotyczące możliwości zawarcia małżeństwa jest niejednakowe dla chłopców i dziewczynek. Zgodnie z art. 10 Kodeksu rodzinnego i opiekuńczego ${ }^{29}, \mathrm{z}$ ważnych powodów sąd opiekuńczy może zezwolić na zawarcie małżeństwa kobiecie, która ukończyła lat 16, a zalegalizowanie związku będzie zgodne z dobrem założonej rodziny. Wraz z zawarciem małżeństwa kobieta uzyskuje zdolność do czynności prawnej i przestaje być dzieckiem w rozumieniu ustawy. Międzynarodowe prawa człowieka stoją na stanowisku, że odpowiednim wiekiem do zawarcia związku małżeńskiego jest 18 rok życia - bez względu na płeć - co znajduje potwierdzenie w CRC i zostało potwierdzone przez KPD i Komitet ds. Likwidacji Dyskryminacji Kobiet w połączonej rekomendacji ${ }^{30}$. Jak podniesiono w „Zielonej Księdze Nierówności”, nastolatki niezależnie od płci

mają podobną wiedzę na temat życia rodzinnego, podobne doświadczenie życiowe oraz podobnie nie są przygotowani do zakładania własnej 'podstawowej komórki społecznej. Jednak prawo traktuje ich inaczej. Okazuje się, że w przekonaniu ustawodawcy dziewczynka, która ukończyła 16 lat, jest zdolna do założenia rodziny, a chłopak nie. Ale czy na pewno jest to kwestia płci, czy może ustawodawca możliwość uprawnienia do czynności prawnych uzależnił od płci osoby, z którą dziecko zawiera związek małżeński ${ }^{31}$.

W świetle powyższych rozważań, takie sformułowanie przepisu przez ustawodawcę nie znajduje uzasadnienia i wskazuje na niejednakowe traktowanie dziewczynek oraz chłopców.

Wszystkie te przykłady świadczą o niskiej świadomości polskiego ustawodawcy dotyczącej nie tylko intersekcjonalnej dyskryminacji, ale też dyskryminacji z uwagi na płeć. Ofiarami patriarchalnych ustaw są kobiety, a kwestia praw dziewczynek z uwagi na zwielokrotnioną dyskryminację - jest jeszcze częściej pomijana przez ustawodawcę, pomimo obowiązku tzw. gender mainstreaming $u^{32}$.

27 Zob.: CRC/C/POL/CO/3-4.

28 Tamże., para38d.

29 Dz. U. $1964 \mathrm{nr} 9$ poz. 59.

30 Zob.: CEDAW/C/GC/31-CRCC/C/GC/18.

31 A. Niżyńska, M. Płatek, I. Przybysz, Zielona ksiegga Nierówności, Warszawa 2016, s. 52.

32 Zob.: C. Bacchi, J. Eveline, Gender mainstreaming or Diversity Mainstreaming? The Politics of ,Doing", „Nordic Journal of Feminist and Gender Research“, nr 17/2009. 


\section{Dzieci romskie}

Przynależność do mniejszości etnicznej zwiększa ryzyko dyskryminacji, w szczególności jeżeli związane są z nią stereotypy i uprzedzenia. Sytuacja ludności romskiej w Polsce i na świecie jest wyjątkowo trudna, bowiem od stuleci jest ona marginalizowana i pomijana ${ }^{33}$. Zdaje się, że uprzedzenia wobec tej mniejszości są nie tylko ugruntowane $\mathrm{w}$ społeczeństwach europejskich, ale też szeroko akceptowane. Tym większe powinno być zaangażowanie prawodawcy w eliminację barier strukturalnych poprzez programy pomocowe i kampanie społeczne. Jak wynika z raportu o sytuacji społeczności romskiej w Polsce, wciąż brak jest efektywnej ochrony przed dyskryminacją ${ }^{34}$. Biurokratyzacja i niedostateczna znajomość języka polskiego sprawiają, że członkowie społeczności romskiej nie są w stanie przezwyciężyć samodzielnie barier napotykanych w urzędach czy szkołach. Stereotypy z kolei mogą stanowić przeszkodę w zgłaszaniu doświadczeń przemocy, ponieważ - jak wynika z przeprowadzonych badań - wielu Romów zdaje sobie sprawę, że nie zostaną z należytą powagą potraktowani przez policję ${ }^{35}$.

Uprzedzenia w stosunku do społeczności romskiej są przede wszystkim szkodliwe dla dzieci. KPD zwraca uwagę na praktykę przydzielania dzieci romskich do szkół specjalnych. Taki proceder, który zakończył wyrok Europejskiego Trybunału Praw Człowieka (ETPCz, Trybunał) w Strasburgu, miał miejsce na szeroką skalę w Czechach oraz na Słowacji. Sprawa DH i inni przeciwko Czechom dotyczyła częstego umieszczenia dzieci romskich w szkołach specjalnych. Decyzja ta była poprzedzona stosownymi testami, a ponadto rodzice musieli wyrazić na to zgodę. Skarżący podnieśli, że umieszczenie w szkołach specjalnych było wyrazem ogólnej praktyki, która skutkowała segregacją i dyskryminacją na tle rasowym, szczególnie z uwagi na fakt, że liczba dzieci romskich w tych szkołach była nieproporcjonalnie wysoka. Trybunał odniósł się do tych zarzutów, podnosząc, że

w wyniku burzliwej historii i ciągłego wysiedlania społeczność romska stała się specyficznym rodzajem narażonej mniejszości znajdującej się w trudnej sytuacji (...) z tego powodu grupa ta wymaga specjalnej ochrony (...). Ochrona ta obejmuje również sferę edukacji, co potwierdziły działania wielu organizacji europejskich i międzynarodowych (...). Dlatego też niniejsza sprawa wymaga szczególnej uwagi, głownie ze względu na fakt, że w chwili zgłoszenia skargi do Trybunału skarżący byli osobami niepełnoletnimi, dla których prawo do nauki ma nadrzędne znaczenie ${ }^{36}$.

${ }^{33}$ M. Matache, The Deficit of EU Democracies: A New Cycle of Violence Against Roma Population, „Human Rights Quarterly“, nr 36/2014, s. 327.

${ }^{34} \mathrm{http}$ ://www.romowie.com/raport.pdf.

${ }_{35}$ M. Matache, dz. cyt., s. 335.

${ }^{36}$ DH i inni przeciwko Czechom, skarga nr 57325/00, para182. 
Chociaż ETPCz nie zaznaczył, że dzieci romskie doświadczyły intersekcjonalnej dyskryminacji, to wydaje się, że ta sprawa jest najlepszym przykładem mogącym służyć analizie intersekcjonalnej. Osoby, które zostały przydzielone do klasy specjalnej były nie tylko Romami, ale też dziećmi - pozbawionymi prawa głosu we własnej sprawie. Obydwa te czynniki wpłynęły na ich sytuację, ponieważ to rodzice, przez zaniechanie bądź niedoinformowanie, zgadzali się na umieszczenie dzieci w takich szkołach. Należałoby zastanowić się zatem, odnosząc się do podobnych spraw (których bez wątpienia jest wiele w Europie i na świecie), nad klauzulą dobra dziecka (art. 3 CRC) oraz prawem dziecka do wyrażania swojej opinii (art. 9), przeprowadzając intersekcjonalną analizę. W świetle niniejszych rozważań najlepsze zabezpieczenie interesów dziecka nie może zostać pozbawione intersekcjonalnej perspektywy, jeżeli przemawiają za tym okoliczności faktyczne, tak jak w przypadku romskich dzieci.

W przypadku dzieci pochodzenia romskiego istnieje wiele innych, dodatkowych przesłanek, które potencjalnie wzmacniają dyskryminacje, takich jak płeć oraz ubóstwo. Trybunał odniósł się do przejawów dyskryminacji na tym podłożu w wyrokach VC przeciwko Słowacji (przymusowa sterylizacja romskiej kobiety) ${ }^{37}$ oraz Connors przeciwko Zjednoczonemu Królestwu (przymusowa eksmisja Romów) ${ }^{38}$. Wyroki te są zakończeniem jednych $\mathrm{z}$ wielu rozpatrywanych przez Trybunał spraw dotyczących Romów i Wędrowców ${ }^{39}$. Świadczy to m.in. o tym, że przynależność do społeczności romskiej pozostaje nadal poważną przesłanką wzmacniającą dyskryminację. Dokonując analizy intersekcjonalnej dotyczącej romskiego dziecka, należy wziąć pod uwagę złożoność jego sytuacji, wynikającej nie tylko z pochodzenia, wieku, ale też płci oraz statusu materialnego. Dziewczynki romskie znacznie rzadziej kończą szkołę, co z kolei wpływa na niski poziom wiedzy dotyczącej dostępnych metod zapobiegania ciąży. Również ubóstwo w znacznej mierze kształtuje i determinuje życie romskich dzieci, które dodatkowo napotykają liczne stereotypy nie tylko ze strony społeczeństwa, ale również ze strony osób stosujących prawo - w sądach i urzędach, a także ze strony nauczycieli czy pracowników społecznych ${ }^{40}$. Rozpatrując sytuację osoby przynależącej do społeczności romskiej, należy zawsze mieć na uwadze intersekcjonalność, aby dokonać adekwatnej oceny stanu rzeczy.

\section{Dzieci niepełnosprawne}

Pomimo niewątpliwego znaczenia CRPD, która wytyczyła nowe standardy dla praw człowieka oraz dyskryminacji wielokrotnej (w art. 6), dając nadzieje na przyszłość, dzieci niepełnosprawne wciąż są izolowane od reszty społeczeństwa, odsyłane

\footnotetext{
37 VC przeciwko Słowacji, skarga nr 18968/07.

38 Connors przeciwko Zjednoczonemu Królestwu, skarga nr 39665/98.

39 Zob.: http://www.echr.coe.int/Documents/FS Roma POL.pdf.

${ }^{40}$ M. Matache, dz. cyt., s. 335.
} 
do szkół specjalnych (zamiast integracyjnych) w sprzeczności do standardów edukacji włączającej ${ }^{41}$. Pomimo złożoności sytuacji życiowej każdego niepełnosprawnego dziecka, w pracy tej zostanie zwrócona uwaga na dwie intersekcje: niepełnosprawnych dziewczynek oraz dzieci niepełnosprawnych z terenów wiejskich. Należy pozytywnie ocenić wyszczególnienie i podkreślenie wieloaspektowej sytuacji niepełnosprawnych kobiet w Preambule CRPD. Trzeba jednak zauważyć, że pomimo gwarancji zawartych w Konwencji, kobiety wciąż narażone są w sposób szczególny na dyskryminację ${ }^{42}$.

Problem ten dobrze oddaje sprawa $X i$ Y przeciwko Holandii, która dotyczyła nastolatki z upośledzeniem umysłowym, która ostała zgwałcona w ośrodku dla dzieci niepełnosprawnych ${ }^{43}$. Dziewczynce, $\mathrm{z}$ uwagi na stan zdrowia, odmówiono możliwości złożenia skargi. Postępowanie przeciwko sprawcy w ogóle nie zostało wszczęte, ponieważ skarga nie została złożona osobiście (tylko przez ojca poszkodowanej). Trybunał co prawda stwierdził naruszenie art. 8 ECHR, jednak nie uznał za zasadne rozważenia aspektu dyskryminacyjnego. Taka decyzja nie wydaje się być słuszna z uwagi na przekonywujące przesłanki, które wskazywałyby na konieczność przeprowadzenia analizy intersekcjonalnej.

Specjalnej protekcji wymagają ponadto niepełnosprawne dzieci z terenów wiejskich. Dzieci te mogą mieć szczególną trudność w dostępie do rehabilitacji, o czym stanowi art. 26(b) CRPD, nakazujący stworzenie usług i programów tak, aby wspierały integrację osób niepełnosprawnych, włączając je we wszystkie aspekty życia społeczeństwa również na obszarach wiejskich. Konwencja podkreśla także konieczność zapewnienia opieki zdrowotnej możliwie blisko społeczności, w których żyją osoby niepełnosprawne - w tym na obszarach wiejskich (art. 25(c)).

Dodatkowo należy zwrócić uwagę na to, że niepełnosprawne dzieci na terenach wiejskich mogą znacznie częściej padać ofiarą stereotypów oraz szkodliwych uprzedzeń, również z uwagi na niską świadomość społeczną. Ponadto mogą przez długi czas pozostawać niezdiagnozowane z uwagi na nieświadomość rodziców, szczególnie dotyczącą chorób psychicznych oraz upośledzeń umysłowych, takich jak autyzm ${ }^{44}$. Zgodnie zatem z wytycznymi teorii przecięć, ustawodawca polski powinien uwzględnić skomplikowaną sytuację grup i jednostek dotkniętych niepełnosprawnością.

\section{Społeczność LGBTQ i intersekcjonalność}

Przynależność do społeczności LGBTQ wiąże się z wieloma trudnościami. Prawa człowieka $\mathrm{z}$ uwagi na odmienność kulturową i obyczaje obowiązujące w różnych

${ }^{41}$ T. Mayes, dz. cyt., s. 97.

42 F. Mégret, The Disabilities Convention: Human Rights of Persons with Disabilities or Disability Rights?, „Human Rights Quaterly”, nr 30/2008, s. 495

${ }^{43}$ X i Y przeciwko Holandii, skarga nr 8978/80.

${ }^{44}$ Zob.: D. McConnell, G. Llewellyn, Stereotypes, parents with intellectual disability and child protection, „Journal of Social Welfare and Family Law“, nr 3/2002. 
miejscach na świecie nie wyznaczają jasno standardów, do których państwa powinny się stosować. Mimo to stopniowo trybunały praw człowieka próbują narzucić pewne standardy krajom, które w żaden sposób nie regulują kwestii par jednopłciowych ani tzw. „tęczowych rodzin”. Europejski Trybunał Praw Człowieka w sprawie Oliari i inni przeciwko Włochom podniósł, że pary homoseksualne mogą tworzyć stabilne związki, które wymagają ochrony prawnej ${ }^{45}$. Jest to znaczący postęp w regulacji praw człowieka dla osób LGBTQ, mimo że (jeszcze) nie ma obowiązku przyznania parom tej samej płci dostępu do zawarcia małżeństwa. Wyrok ten jest jednakże niesatysfakcjonujący $\mathrm{z}$ uwagi na to, że Trybunał po raz kolejny nie uznał za zasadne rozpatrzenie art. 14, czyli zakazu dyskryminacji. Odmienną wykładnię przyjął Międzyamerykański Trybunał Praw Człowieka (I-ACHR) w swoim orzecznictwie. Sprawa Atala Riffo i córki przeciwko Chile dotyczyła pozbawienia opieki nad dziećmi homoseksualnej matki, z uwagi na jej orientację ${ }^{46}$. I-ACHR stwierdził, że Chile naruszyło m.in. art. 24 (zakaz dyskryminacji) oraz art. 11 (ochrona poszanowania honoru i godności) ACHR. Co więcej, Międzyamerykański Trybunał rozszerzył interpretacje art. 17 ACHR, podnosząc, że rodzina w świetle celów i brzmienia konwencji oznacza również rodzinę homoseksualną. Być może najważniejszym aspektem w uzasadnieniu była jednak interpretacja klauzuli dobra dziecka, które według Trybunału nie może być oparte na krzywdzących stereotypach i uprzedzeniach (bowiem sądy chilijskie uznały, że wychowywanie dzieci przez lesbijkę stoi w sprzeczności z dobrem dziecka).

Sprawy te świadczą o tym, że pomimo stopniowej poprawy sytuacji społeczności homoseksualnej i przychylnej wykładni międzynarodowych trybunałów, wciąż przynależność do społeczności LGBTQ oznacza duże prawdopodobieństwo wieloaspektowej dyskryminacji. Z tego powodu, intersekcjonalizm powinien być brany pod uwagę w każdej sprawie dotyczącej dzieci z rodzin LGBTQ lub identyfikujących się jako osoby homoseksualne ${ }^{47}$.

Szczególnie narażone na ostracyzm i wykluczenie społeczne są nastolatki homoseksualne $\mathrm{z}$ terenów wiejskich. Z raportu $\mathrm{z}$ badań przeprowadzonych przez Fundację Przestrzeń Kobiet w 2012 r. wynika, że nieheteroseksualne nastolatki mieszkające poza dużymi ośrodkami miejskimi, uczęszczające do szkoły, doświadczają aktów mowy nienawiści, przemocy psychicznej i fizycznej, a jednocześnie mają utrudniony dostęp do pomocy psychologicznej. Ponadto, ze względu na status społeczno-ekonomiczny i miejsce zamieszkania, są izolowane społecznie, bez możliwości budowania więzi społecznościowych. W Raporcie podkreślono, że projekty społeczne przeciwdziałające dyskryminacji ze względu na wiek, płeć i orientację seksualną są niedostatecznie wspierane i finansowane ${ }^{48}$. Ponadto w literaturze wskazuje się na fakt, że istnieje nie

${ }^{45}$ Oliari i inni przeciwko Włochom, skarga nr 18766/11 i 36030/11.

${ }^{46}$ Atala Riffo i córki przeciwko Chile, sprawa nr 12.502.

47 T. Mayes, dz. cyt., s. 100.

${ }^{48}$ Zob.: J. Struzik, Niewidoczne (dla) społeczności. Sytuacja społeczna lesbijek i kobiet biseksualnych na terenach wiejskich i w matych miastach $w$ Polsce. Raport $z$ badań, Kraków 2012. 
tylko potrzeba walki z wykluczeniem społecznym na terenach wiejskich, ale też rzetelnej analizy uwzględniającej kwestię płci $^{49}$ oraz wszystkich innych kategorii wzmacniających marginalizację, czyli analizy intersekcjonalnej.

\section{Konkluzje}

Intersekcjonalność niewątpliwie zyskała na popularności i jest propagowana przez środowiska feministyczne. Należy jednak ponownie podkreślić, że sukces teorii przecięć może być mierzony dopiero realnym wpływem na zmiany legislacyjne. Dotychczas, zarówno na arenie międzynarodowej, jak i w Polsce, istnieją akty i przepisy chroniące tylko przed jednym rodzajem dyskryminacji (co świadczy o tzw. intersekcjonalnej niewidzialności). Tylko nieliczne dokumenty uwzględniają wieloaspektową dyskryminację (np. CRPD). Wydaje się, że zanim ustawodawca dostrzeże konieczność uwzględnienia perspektywy intersekcjonalnej, analiza ta powinna być dokonywana przez podmioty stosujące prawo oraz wszystkie osoby, które mają wpływ na życie dzieci narażonych na dyskryminację. Jest to szczególnie istotne z uwagi na fakt, że - jak pokazuje przykład orzecznictwa ETPCz - sądy i trybunały wciąż niesłusznie pomijają analizę zakazu dyskryminacji.

W niniejszej pracy zostały omówione wyłącznie niektóre, wybrane „skrzyżowania” różnych kategorii społecznych, które wzmagają marginalizację i trudną sytuację dzieci, w celu zwrócenia uwagi na mnogość możliwości intersekcjonalnej dyskryminacji. Koncepcja intersekcjonalna proponuje odstąpienie od generalizacji i uogólnień (takich jak w przypadku standardowych antydyskryminacyjnych regulacji), kładąc nacisk na sytuację jednostki. Stanowi to swoistą obronę przed zbędnym esencjalizmem, który może prowadzić do uproszczeń i wtórnych stereotypów ${ }^{50}$. Dodatkowo w pracy tej starano się zwrócić uwagę na to, że analiza intersekcjonalna jest w zgodzie z prawami dziecka, a w szczególności - z klauzulą dobra dziecka, która zakłada, że we wszystkich działaniach dotyczących nieletniego będzie wybierane (w każdej sytuacji go dotyczącej) najkorzystniejsze dla niego wyjście. Dobro dziecka wymaga od organu stosującego prawo podjęcia decyzji zgodnie z zasadami postępowania o uzasadnieniu aksjologicznym oraz do dokonania zindywidualizowanej oceny związanej z konkretnym przypadkiem ${ }^{51}$. Zatem, pomimo tego, że pojęcie interesu dziecka stanowi interpretacyjne wyzwanie, uwzględnienie perspektywy intersekcjonalnej niewątpliwie stanowi konieczny element pomagający w prawidłowej ocenie sytuacji indywidualnego dziecka i w niwelowaniu jego trudnego położenia.

${ }^{49}$ M. Borys, Rasa, klasa, płeć $i$ wieś. Feministyczne epistemologie marginesu, „Praktyka teoretyczna", nr 4(10)/ 2013, s. 43.

${ }^{50}$ R. Kapur, dz. cyt., s. 6.

${ }^{51}$ K. Mendecka, Klauzula dobra dziecka $w$ Konwencji o prawach dziecka $i$ w prawie polskim (wybrane problemy), „Folia Iuridica“, nr 77/2017, s. 32. 


\section{Bibliografia}

Bacchi C., Eveline J., Gender mainstreaming or Diversity Mainstreaming? The Politics of ,Doing،, „Nordic Journal of Feminist and Gender Research“, nr 17/2009, s. 2-17.

Boryczko M. i inni, Przeciw biedzie. Socjologiczno-pedagogiczny przyczynek do nowych rozwiązań starego problemu, Europejskie Centrum Solidarności, Gdańsk 2016.

Bruce A., Which Entitlements and for Whom? The Convention on the Rights of Persons with Disabilities and its Ideological Antecedents, Media-Tryck, Lund 2014.

Crenshaw K., Demarginalizing the Intersection of Race and Sex: A Black Feminist Critique of Antidiscrimination Doctrine, Feminist Theory and Antiracist Politics, „University of Chicago Legal Forum”, nr 1/1989, s. 139-167.

Crenshaw K., Schulz P., Intersectionality in Promoting Equality, „The Equal Rights Review“, nr 16/2016, s. 207-219.

Dill B., Zambrana R., Emerging Intersections: Race, Class and Gender in Theory, Policy and Practice, Rutgers University Press, New Brunswick - New Jersey - Londyn 2009.

Kapur R., The Tragedy of Victimization Rhetoric: Resurrecting the „Native” Subject in Internaional/Post-Colonial Feminist Legal Politics, „Harvard Human Rights Journal", nr 15/2002, s. 1-37

Mayes T., Understanding Intersectionality between the Law, Gender, Sexuality and Children, „Children's Legal Rights Journal“, nr 26/2016, s. 90-106.

McConnell D., Llewellyn G., Stereotypes, parents with intellectual disability and child protection, „Journal of Social Welfare and Family Law“, nr 3/2002, s. 297-317.

Mégret F., The Disabilities Convention: Human Rights of Persons with Disabilities or Disability Rights?, „Human Rights Quaterly”, nr 30/2008, s. 762-778.

Mendecka K., Klauzula dobra dziecka $w$ Konwencji o prawach dziecka $i$ w prawie polskim (wybrane problemy), „Folia Iuridica“, nr 77/2017, s. 25-36.

Niżyńska A., Płatek M., Przybysz I., Zielona księga Nierówności, Instytut Spraw Publicznych, Warszawa 2016.

Quinn G., Reflections on the Value of Intersectionality and the Development of NonDiscrimination Law, „The Equal Rights Review“, nr 16/2016, s. 63-72.

Smith B., Intersectional Discrimination and Substantive Equality: A Comparative and Theoretical Perspective, „The Equal Rights Review“, nr 16/2016, s. 73-102.

Struzik J., Niewidoczne (dla) społeczności. Sytuacja społeczna lesbijek i kobiet biseksualnych na terenach wiejskich $i$ w małych miastach $w$ Polsce. Raport $z$ badań, Fundacja Przestrzeń Kobiet, Kraków 2012. 


\section{Redressing disadvantage: intersectional approach to children's plight}

Abstract: This article focuses on children who experience intersectional discrimination, as they are oftentimes omitted entirely not only in literature, but also in law, and by courts and tribunals, at the international and domestic level. The number of children whose identities interplay is insurmountable, and they should not be forced to seek protection under one form of marginalized identity. Instead, their intersecting identities should be analyzed and taken into consideration together, as it seems to be an imperative tool to improve children's protection and enrich academic and political discourse on that matter.

Keywords: intersectionality, children's rights, discrimination, multidimensional discrimination, best interest of the child

About the author: Karolina Mendecka is a $\mathrm{PhD}$ candidate at the Institute of Theory and Philosophy of Law, Faculty of Law and Administration at University of Łódź. She is also International Human Rights Law student at Lund University and R. Wallenberg Institute. Her research focuses primarily on human rights issues, children's and women's rights and general principles of international law. 


\title{
Daniel Kukla*
}

\author{
Akademia im. Jana Długosza w Częstochowie \\ d.kukla@vp.pl
}

\section{Między uczelnią a rynkiem pracy - perspektywy młodych}

\begin{abstract}
Streszczenie: Współczesny rynek pracy to obszar wymagający odpowiedniego przygotowania. Sprawne funkcjonowanie jednostki w tym złożonym systemie wymaga przede wszystkim zmiany myślenia o bezpieczeństwie zatrudnienia oraz nastawienia na pracę jako obszaru permanentnego zdobywania nowych umiejętności charakteryzujących indywidualność jednostki w danym obszarze funkcjonowania zawodowego. Zmieniający się wciąż rynek pracy w pewien sposób wymusza stałe doskonalenie się, najlepiej w różnych dziedzinach jednocześnie. Wymaga elastyczności, mobilności i kreatywności. Jednostka musi się z tym pogodzić i starać się sprostać wymaganiom dzisiejszych pracodawców. W opracowaniu zarysowano współczesne realia przygotowania do wejścia na rynek pracy oraz możliwości funkcjonowania na nim.
\end{abstract}

Słowa kluczowe: edukacja wyższa, rynek pracy, młode pokolenia, zatrudnienie.

\section{Wprowadzenie}

W obecnej sytuacji społeczno-gospodarczej niezwykle ważna jest dyskusja na temat funkcjonowania współczesnego rynku pracy - zwłaszcza w kontekście roli, jaką na owym rynku pełnią młodzi ludzie. Dyskusja ta powinna odbywać się zarówno

* Dr hab. Daniel Kukla - autor kilkudziesięciu opracowań naukowych i metodycznych z zakresu doradztwa zawodowego opublikowanych w kraju jak i za granicą w językach kongresowych. Uczestnik konferencji o zasięgu międzynarodowym i krajowym. Aktywnie współpracujący z wieloma ośrodkami akademickim w Polsce. Recenzent opracowań naukowych oraz metodycznych. Członek zespołów badawczych w projektach międzynarodowych dotyczących aktywizacji zawodowej i doradztwa edukacyjno-zawodowego dla różnych grup odbiorców we współpracy m.in. z Ruprecht-Karls-Universitat Heidelberg oraz Hochschule der Bundesagentur für Arbeit w Mannheim (Niemcy). Naukowe zainteresowania badawcze koncentrują się wokół znaczeniem pracy w życiu młodego człowieka oraz określenie roli, jaką pełni współcześnie doradztwo edukacyjno-zawodowe w projektowaniu przyszłości zawodowej człowieka, a tym samym w przygotowaniu go do tranzycji z edukacji na rynek pracy. 
wśród ustawodawców, przedstawicieli rynku pracy, pracodawców, przedstawicieli resortu edukacji, jak również przy udziale samych zainteresowanych - studentów i absolwentów.

Rola, jaką odgrywa w tym przypadku uczelnia wyższa, wydaje się mieć kluczowe znaczenie w kontekście przygotowania przyszłych absolwentów do pracy na konkretnych stanowiskach zawodowych (zaopatrzenie w niezbędną wiedzę i umiejetności) oraz do wkroczenia na rynek pracy (rozwjanie umiejętności poszukiwania pracy, autoprezentacji itd.). Pomoc ze strony uczelni powinna polegać na udzielaniu wsparcia w szeroko pojętym procesie rozwoju zawodowego, począwszy od wyboru kierunku studiów, specjalności, poprzez dobór odpowiednich form rozwoju kompetencji w trakcie studiów i po studiach, aż po przygotowanie młodych osób do wejścia na rynek pracy.

\section{Absolwent na rynku pracy}

Współczesność oczekuje i zarazem wymaga od systemu edukacji znalezienia sposobu na sprostanie nowym wyzwaniom w obszarze kształcenia i edukowania młodego pokolenia, pokolenia „jutra”, które będzie wyznaczać bieg nie tylko wszelkim przemianom społeczno-gospodarczym i trendom (m.in.: na rynku edukacji i pracy), ale będzie także kreatorem owych obszarów. Dziś edukacja musi dostosowywać się na bieżąco do zmian, jakie dokonują się „tu i teraz”, których jesteśmy świadkami i sprawcami. Jak pisze Zbyszko Melosik:

obecnie dyplom dobrej uczelni, choć stanowi przepustkę do kariery, jest już jednak tylko symbolem (żyjemy w warunkach „inflacji dyplomu”). Wykształcenie nie jest uzyskiwane raz na zawsze. Człowiek, jeśli chce się wspinać po drabinie awansu zawodowego, musi przyjąć do wiadomości, że jego wykształcenie, a także kolejne formy wiedzy, kompetencji i kwalifikacji, które zdobywa $\mathrm{w}$ trakcie dokształcania sie, podlegają nieustannej dewaluacji ${ }^{1}$.

Zmieniający się wciąż rynek pracy wymusza na młodym człowieku stałe doskonalenie się, najlepiej w różnych dziedzinach jednocześnie. Wymaga elastyczności, dynamiczności, mobilności i kreatywności. Jednostka musi się z tym pogodzić i starać się sprostać wymaganiom dzisiejszego, permanentnie zmieniającego się rynku pracy. Umiędzynarodowienie i ciągłe przemiany, jakie zachodzą w obszarze pracy ludzkiej, a tym samym i na rynku, wymuszają ustawiczne dostosowywanie się jednostki do nowych norm i zasad panujących w świecie pracy. Na tej podstawie można stwierdzić, że wkraczamy w tzw. rynek pracownika. Pracodawcy coraz częściej miewają problemy z niedoborem kadry i brakiem możliwości zrekrutowania odpowiednich podwładnych. Z drugiej strony, wciąż mamy do czynienia również z takimi zawodami,

${ }^{1}$ Z. Melosik, Kultura popularna i tożsamość młodzieży; Wydawnictwo IMPULS, Kraków 2013, s. 326 . 
w których panuje nadwyżka kandydatów w stosunku do zapotrzebowania ze strony pracodawców. Związane jest to z niedopasowaniem kwalifikacyjnym do potrzeb rynku, z liczbą absolwentów nieadekwatną do chłonności rynku pracy w wybranych zawodach. Ukazują to poniższe dane, przedstawione w raporcie Narodowego Centrum Badań i Rozwoju pt. Analiza kwalifikacji i kompetencji kluczowych dla zwiększenia szans absolwentów na rynku pracy.

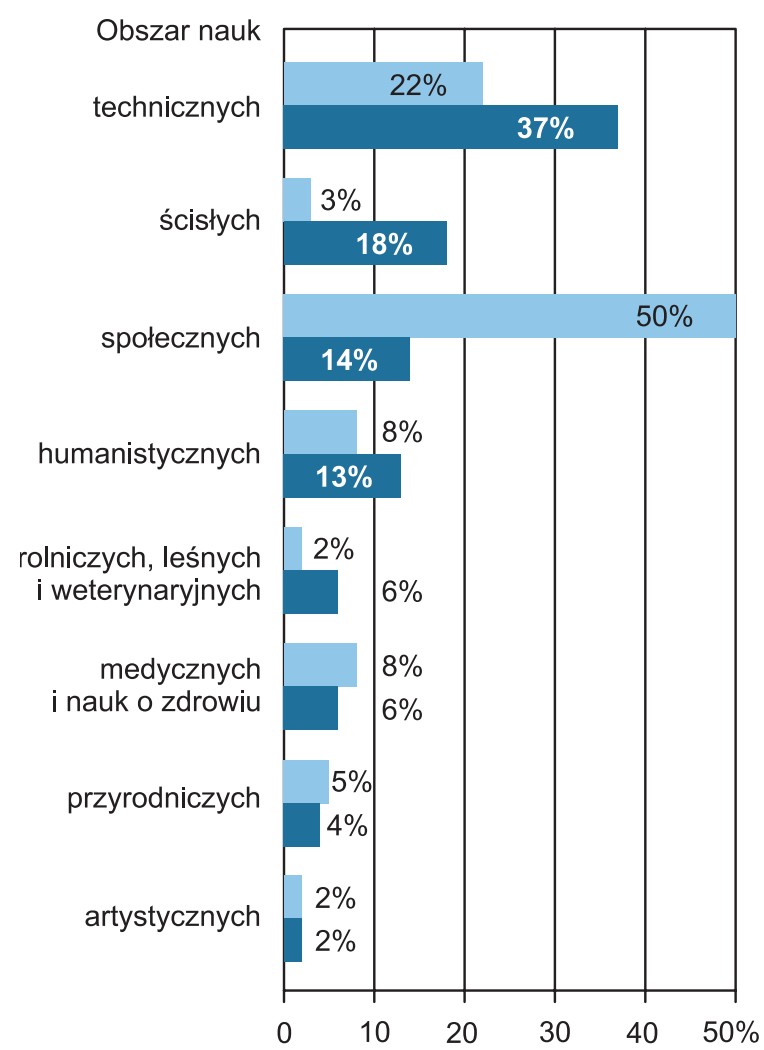

Proporcje absolwentów w strukturze kształcenia

Po jakich kierunkach zatrudniają pracodawcy

Grafika 1. Zestawienie proporcji liczby absolwentów w strukturze kształcenia z prognozami zatrudnienia pracodawców.

Źródło: Pieniążek W., Przybył C., Pacuska M., Chojecki J., Huras P., Pałka S., Ratajczyk J., Rudolf A., Analiza kwalifikacji i kompetencji kluczowych dla zwiększenia szans absolwentów na rynku pracy. Raport końcowy, Wydawnictwo NCBiR, Warszawa 2014, s. 48.

Jak wskazują specjaliści rynku pracy, ekspansja wykształcenia wyższego postępuje w znacznie szybszym tempie niż rozwój pojemności rynku pracy do absorpcji absolwentów. Mamy zatem do czynienia ze zjawiskiem tzw. luki popytowej, która po- 
lega na niemożności wchłonięcia przez rynek pracy nadmiaru absolwentów uczelni wyższych ${ }^{2}$. Wynikiem tego może być rosnące bezrobocie, niepełne zatrudnienie czy też destabilizacja społeczna. Co więcej, sytuacja ta sprawia, że wraz ze wzrostem masowości szkolnictwa wyższego posiadanie dyplomu uczelni przestaje być gwarantem późniejszego zatrudnienia ${ }^{3}$.

Zdobyte wykształcenie nie wystarczy nam na całe życie, niezbędna jest promocja korzyści wynikających z posiadania wysokich i aktualnych kwalifikacji ${ }^{4}$ oraz odpowiednich kompetencji do wykonywania określonego zawodu. Aby nadążyć za przemianami, trzeba się nieustannie uczyć - przez całe, również dorosłe, życie. Jest to istotną cechą współczesnej edukacji, która w XXI wieku musi być globalna ${ }^{5}$. Edukacja jest powszechnie uznana za główną siłę sprawczą społecznego i gospodarczego rozwoju. Potrzeba rozwoju zasobów ludzkich może następować tylko w wyniku ustawicznej edukacji6.

Szkoły wyższe muszą wyznaczyć sobie niejako nowe cele, bowiem już nie tylko wiadomości i umiejętności decydują o powodzeniu, ale kluczowa jest również odpowiednia postawa.

Uczelnie powinny być szerzej otwarte na swoje otoczenie gospodarcze. (...) jeżeli struktura kształcenia odbiega znacząco od struktury zatrudnienia, potrzeb gospodarki i popytu na określone kwalifikacje lub zawody, wówczas występuje dysfunkcjolnalność i irracjonalność tych struktur ${ }^{7}$.

Polskie uczelnie w takiej strukturze, w jakiej funkcjonują obecnie, nie sa w stanie nadążyć za potrzebami rynku pracy. Szkolnictwo wyższe wykazuje bowiem mniejszą od niego dynamikę zmian dostosowawczych.

W Raporcie o stanie edukacji 2012 czytamy natomiast, że

wobec znaczącej poprawy struktury wykształcenia ludności Polski, coraz większe znaczenie zaczyna mieć nie sam poziom ukończonego kształcenia, ale jego dziedzina i wyuczony zawód oraz ich dostosowanie do potrzeb lokalnego rynku pracy $^{8}$.

Obniżenie się rangi dyplomu uczelni oraz luka kwalifikacyjna i kompetencyjna, na którą wskazują pracodawcy, sprawiają, że sytuacja absolwentów na współczesnym

${ }^{2}$ A. Krajewska, Szkolnictwo wyższe w kontekście potrzeb i problemów rynku pracy, [w:] R. Gerlach (red.), Edukacja wobec rynku pracy. Realia - możliwości - perspektywy, Bydgoszcz 2003, s. 231-232.

3 Tamże, s. 231-232.

${ }^{4}$ Por. A. Matysiak, Kształcenie ustawiczne w Polsce. Korzyści i bariery rozwoju, Polskie Forum Strategii Lizbońskiej, Niebieskie Księgi nr 8, Gdańsk 2003, s. 56.

${ }^{5}$ J. E. Karney, Podstawy psychologii i pedagogiki pracy, Wydawnictwo WSH, Pułtusk 2004, s. 251.

${ }^{6} \mathrm{H}$. Bednarczyk, Rozwój ustawicznej edukacji zawodowej - główne zadania polskiej pedagogiki pracy, [w:] H. Bednarczyk, I. Woźniak (red.), Pedagogika pracy wobec problemów ochrony pracy, Radom 2004, s. 44.

${ }^{7}$ U. Jeruszka, Efektywność kształcenia w szkołach wyższych, „Polityka społeczna”, nr 1/2011, s. 2-3.

${ }^{8}$ Raport o stanie edukacji 2012. Licza się efekty, Wydawnictwo IBE, Warszawa 2013, s. 8. 
rynku pracy nie jest łatwa. Stawia ona nowe wyzwania zarówno przed studentami oraz absolwentami, jak i przed pracodawcami, a przede wszystkim uczelniami - których powinnością jest przygotowanie studentów do radzenia sobie na rynku pracy.

Poniżej przedstawiono dane z raportu Dwa światy. Kompetencje przyszłości 2014: opis badań przeprowadzonych wśród 127 pracodawców ${ }^{9}$.

Grafika 2. Ocena kompetencji studentów i absolwentów vs. ocena kompetencji absolwentów przez pracodawców.

\begin{tabular}{|c|c|c|}
\hline Kompetencje & $\begin{array}{l}\text { Samoocena absolwentów } \\
\text { i studentów (\%) }\end{array}$ & $\begin{array}{l}\text { Ocena według pracodawców } \\
\qquad(\%)\end{array}$ \\
\hline Inteligencja emocjonalna & 60 & 26 \\
\hline Przetwarzanie dużej ilości informacji & 59 & 25 \\
\hline Doprowadzanie zadań do końca & 85 & 38 \\
\hline Koncentracja i selekcja informacji & 67 & 30 \\
\hline Adaptowanie się do nowych warunków & 67 & 41 \\
\hline Kreatywność, innowacyjność & 56 & 43 \\
\hline Samodzielność & 78 & 32 \\
\hline Wielozadaniowość & 65 & 23 \\
\hline Świadomość swoich mocnych i słabych stron & 63 & 27 \\
\hline $\begin{array}{l}\text { Radzenie sobie w zaskakujących i trudnych } \\
\text { sytuacjach }\end{array}$ & 51 & 20 \\
\hline Radzenie sobie ze stresem & 43 & 18 \\
\hline Doświadczenie zawodowe w branży & 28 & 17 \\
\hline Proaktywność & 40 & 15 \\
\hline Budowanie dobrych relacji & 81 & 35 \\
\hline Praca zespołowa & 79 & 37 \\
\hline Systematyczność & 72 & 34 \\
\hline Przekuwanie pomysłów w działanie & 49 & 23 \\
\hline Otwartość na pomysły i wiedzę innych & 78 & 32 \\
\hline
\end{tabular}

Grafika 2. Ocena kompetencji studentów i absolwentów vs. ocena kompetencji absolwentów przez pracodawców.

Źródło: Strona internetowa - http://kariera.kozminski.edu.pl/fileadmin/kariera.kozminski.edu.pl/Raporty/RAPORT_KOMPETENCJE_PRZYSZLOSCI_-_pracodawca.pdf (dostęp: 20.05.2017).

$\mathrm{Na}$ podstawie przedstawionych danych można wnioskować, że istnieje luka kompetencyjna na rynku pracy. Pracodawcy dostrzegają braki kompetencyjne u absolwentów; co ciekawe, działa to jednostronnie - braków tych nie widzą kończący

${ }^{9}$ http://kariera.kozminski.edu.pl/fileadmin/kariera.kozminski.edu.pl/Raporty/RAPORT KOMPETENCJE PRZYSZLOSCI - pracodawca.pdf (dostęp: 20.05.2017). 
studia; mają tendencję do oceniania siebie znacznie lepiej niż pracodawcy. Może to wynikać z zawyżonej samooceny studentów i absolwentów lub $\mathrm{z}$ wygórowanych wymagań pracodawców, niemniej jednak taka sytuacja może powodować niezrozumienie i w negatywny sposób wpływać na współpracę. Z drugiej strony, należy wskazać, że skoro pracodawcy wysoko cenią sobie określone kompetencje (i szukają ich u swoich pracowników/kandydatów do pracy), ale jednocześnie nie znajdują ich u absolwentów, to konkretne wnioski powinny być $\mathrm{z}$ tego wyciągnięte zarówno przez absolwentów, jak i szkoły wyższe. Jest to więc kolejny argument do wprowadzania zmian i kolejne wyzwanie (wynikające z deklarowanych przez pracodawców potrzeb) dla współczesnych uczelni. Podsumowując dotychczasowe rozważania, można podkreślić, że absolwenci znaleźli się niejako w trudnych czasach - duża konkurencja, szybkie tempo życia, obniżenie się rangi dyplomu uczelni (nie wystarczy go już tylko mieć). To wszystko sprawia, że studenci już na etapie studiów powinni zatroszczyć się o rozwój swojej kariery zawodowej, podejmować dodatkowe aktywności. Oczywiście nie mogą zostać pozostawieni samym sobie. Zarówno szkoły wyższe (wraz z innymi instytucjami, których zadaniem jest wspieranie studentów i absolwentów w procesie tranzycji), jak również pracodawcy powinni odnaleźć się w tej nowej sytuacji. Dla każdego z tych podmiotów jest to ważne i świadczy wręcz o jego „być albo nie być” na rynku - tak dla uczelni, które walczą obecnie o wytworzenie w umysłach studentów i kandydatów na studia wizerunku szkoły przygotowującej do wejścia na rynek pracy, jak również dla pracodawców, którzy walczą o dobrego pracownika.

Pracodawcy powinni być gotowi i otwarci na współpracę z uczelniami i w odpowiedni sposób zadbać o adaptację nowych pracowników (w tym absolwentów). Po ich stronie istnieje również powinność przeszkolenia podwładnych. Łatwiej jest nauczyć człowieka konkretnych umiejętności zawodowych, jeśli jest on wyposażony w kompetencje ogólne, takie jak choćby szybkość uczenia się, adaptacji, radzenia sobie z trudnymi warunkami. Pracodawcy powinni być tego świadomi. Ponadto ważne jest, aby przygotowywali się na przyjęcie i zarządzanie pracownikami nowego pokolenia. Jest to temat na odrębną dyskusję, ale warto podkreślić istnienie tej kwestii. Pracodawcy mogą również współpracować ze szkołami wyższymi, np. w zakresie ustalania programów studiów, planów praktyk, organizowania wspólnych eventów takich, które angażują studentów, zachęcają do działania, pozwalają np. na rywalizacje (np. programy „grasz o staż") czy stworzenie czegoś nowego (opracowanie projektu lazika na Marsa) itd.

Brak konkretnych kompetencji, które określane są często mianem kluczowych, oraz brak doświadczenia znacząco obniżają możliwości zatrudnieniowe młodych ludzi. Kwestia niedopasowania systemu edukacji do rynku pracy była przedmiotem badań przeprowadzonych przez Polską Agencję Rozwoju Przedsiębiorczości w ramach badania Bilansu Kapitału Ludzkiego. Wynika z nich, że coraz więcej osób odpowiedzialnych za zatrudnienie $w$ przedsiębiorstwach przyznaje, że absolwenci nie tylko nie 
maja odpowiednich kwalifikacji zawodowych, ale też umiejętności społecznych, by zaczać pracować ${ }^{10}$.

Podobne wnioski zawarte są w raporcie Młodzi na rynku pracy. Pod lupą. Sytuacja młodych na rynku pracy z perspektywy przedsiębiorstw MŚP.

Opinie przedsiębiorców ${ }^{11}$ na temat młodych jako pracowników są różnorodne. Pracodawcy zapytani o kompetencje i wiedzę młodych osób w relacji do potrzeb i oczekiwań firm są podzieleni: 47,1 proc. uważa je za zdecydowanie lub raczej niewystarczające, a 45 proc. za raczej lub zdecydowanie wystarczające. (...) młodzi ludzie opuszczają szkoły nieprzygotowani do pracy ${ }^{12}$.

Współcześni studenci oczekują od swojej uczelni konkretnej wiedzy i konkretnych umiejętności, cennych z punktu widzenia zawodu. Wydawać by się mogło zatem, że obecnie młodzi ludzi bardziej pragmatycznie podchodzą do swojej edukacji. Jest to dla nich swoistego rodzaju inwestycja w przyszłość, która może zaowocować wymiernymi efektami w postaci zdobycia pracy w zawodzie. Młodzi ludzie zdają sobie sprawę z faktu, że obecnie na rynku pracy cenne są umiejętności praktyczne i doświadczenie, stąd też ich oczekiwania względem uczelni są do tego niejako dostosowane. Kształcenie na uczelni wyższej jest dla studenta prostą drogą do zdobycia uprawnień zawodowych. Rola uczelni ewoluowała. W przeszłości okres studiów był czasem poszerzania horyzontów, zdobywania wiedzy ogólnoakademickiej i szeroko rozumianego wykształcenia; dziś jest to raczej czas na zdobycie konkretnego fachu, zawodu. Często też czas nauki łączony jest ze zdobywaniem pierwszych doświadczeń zawodowych. Zmiana ta podyktowana jest oczywiście duchem czasu, zmianami jakie następują na rynku pracy - uczelnie wyższe muszę się do tego dostosować. Powinny mieć jednak świadomość, że nadal są uczeniami wyższymi, a nie szkołami zawodowymi, które kształtują jedynie umiejętności praktyczne i przekazują wiedzę branżową. Pamiętać należy, że kompetencje osobiste, wiedza ogólna, określone postawy, wartości moralne to również cenne zasoby na rynku pracy - zasoby, które niegdyś były mocno kojarzone z uczelnią wyższą o wysokim prestiżu, a dziś wydają się odchodzić w zapomnienie.

Wyniki badań przytoczone $\mathrm{w}$ raporcie specjalnym, który opublikowany został w ramach projektu Biznes dla edukacji ${ }^{13}$, wskazują, że

${ }^{10}$ http://www.kwalifikacje.edu.pl/pl/component/content/article/56-opinie-o-ramie/468kierunki-studiow-we-wspolpracy-z-firmami (dostęp: 11.09.2016).

${ }^{11}$ W badaniu „Młodzi pod lupą” wzięło udział 800 firm w całym kraju. Badanie wykonano metodą ilościową, techniką CATI wśród mikro-, małych i średnich firm (zatrudniających do 250 osób).

${ }_{12}$ Młodzi na rynku pracy. Pod lupa. Raport - Sytuacja młodych na rynku pracy z perspektywy przedsiębiorstw, MŚP, Warszawa 2014, s. 14-15.

13 A. Jawor-Joniewicz, Biznes dla edukacji. Raport specjalny dotyczący współpracy biznesu i edukacji w Polsce, Wydawnictwo PARP, Warszawa 2013; http://www.hrtrendy.pl/2014/06/24/studenci-nie-znaja-oczekiwan-pracodawcow-raport-parp/ (dostęp: 26.09.2014). 
wiedza oraz przeświadczenia młodych ludzi na temat wymagań rynku pracy, jak również oczekiwań pracodawców, nie są adekwatne do rzeczywistości. Studenci raczej nie doceniają wagi kompetencji miękkich na rynku pracy, uznając je za najmniej istotne ${ }^{14}$.

Uczelnie stają obecnie przed sporym wyzwaniem - z jednej strony muszą sprostać oczekiwaniom studentów - bądź co bądź swoich klientów. Z drugiej jednak strony nie mogą przekształcić się jedynie w szkoły zawodowe - wszak zadaniem uczelni powinien być także rozwój ogólnoakademicki. Ich działania powinny być także dostosowane do wymagań pracodawców (które bywają zdecydowanie rozbieżne z oczekiwaniami studentów). Warto zasygnalizować, że uczelnie sukcesywnie prowadzą badania satysfakcji studentów czy też ich oczekiwań, co jest asumptem do tego, aby dostosowywać swoją ofertę do potrzeb interesariuszy zarówno wewnętrznych (studentów), jak i zewnętrznych (pracodawców).

\section{Podsumowanie}

Pracodawcy oczekują, że kandydaci do pracy będą wyposażeni w wiedzę, umiejętności i kompetencje, które niezbędne są do wykonywania pracy na danym stanowisku. Uczelnie powinny zatem dostosowywać swoje programy kształcenia do wymagań pracodawców, głównie w zakresie tych elementów, których deficyt zgłaszają pracodawcy. Są to m.in.: praca zespołowa, kreatywność, innowacyjność, wielozadaniowość, radzenie sobie w trudnych sytuacjach, samodzielność. Zdaniem pracodawców tych kompetencji brakuje absolwentom - uczelnie wyższe, aby stać się bardziej dopasowanymi do rynku pracy, powinny uwzględniać ten fakt przy okazji planowania swoich działań, ustalania programów studiów, efektów kształcenia itd. Przykładowo, wspomniane już wcześniej kompetencje miękkie można rozwijać już na etapie studiów, wprowadzając bardziej nowoczesne (kreatywne) metody nauczania, pobudzające studentów do rozwoju, zachęcające do samodzielnego działania, jak np. metoda projektowa, symulacje pracy. Efekty takie można osiągnąć prawie na każdym realizowanym przedmiocie, ale także na zajęciach wprost mających za cel wykształcenie takich postaw (wszelkie warsztaty umiejętności społecznych, trening interpersonalny). Są to przedmioty, które powinny znaleźć się w siatce każdego kierunku (od psychologii po metalurgię czy matematykę stosowaną). Taka potrzeba wynika wprost z deklarowanych przez pracodawców potrzeb. Gospodarczo-społeczna wartość szkolnictwa wyższego należy mierzyć stopniem zaspokojenie aktualnych potrzeb gospodarki i stopniem wzmacniania jej dynamiki rozwojowej ${ }^{15}$. Pracodawcy

zatrudniają pracowników w oparciu o wiele czynników - istotne są nie tylko kwalifikacje, ale również szeroki wachlarz umiejętności (interpersonalnych, anali-

\footnotetext{
14 Tamże.

15 U. Jeruszka, dz. cyt., s. 1.
} 
tycznych), cechy osobowości i czynniki demograficzne. Kwalifikacje i kompeten-

cje odgrywają coraz większą rolę w kontekście szans młodych na rynku pracy ${ }^{16}$.

Zmieniająca się ciągle rzeczywistość wymaga nie tylko szybkiego przystosowywania się do zaistniałych sytuacji, ale przede wszystkim odnalezienia własnego miejsca we współczesnym świecie, w pewnym stopniu - dopasowania się do niego.

\section{Bibliografia}

Bednarczyk H., Rozwój ustawicznej edukacji zawodowej - główne zadania polskiej pedagogiki pracy, [w:] H. Bednarczyk, I. Woźniak (red.), Pedagogika pracy wobec problemów ochrony pracy, Wydawnictwo ITE-PIB, Radom 2004.

Jawor-Joniewicz A., Biznes dla edukacji. Raport specjalny dotyczący współpracy biznesu $i$ edukacji w Polsce, Wydawnictwo PARP, Warszawa 2013.

Jeruszka U., Efektywność kształcenia w szkołach wyższych, „Polityka społeczna”, nr 1/2011, s. 1-3.

Karney J. E., Podstawy psychologii i pedagogiki pracy, Wydawnictwo WSH, Pułtusk 2004. Kierunki studiów we współpracy z firmami, http://www.kwalifikacje.edu.pl/pl/component/content/article/56-opinie-o-ramie/468-kierunki-studiow-we-wspolpracy-z-firmami (dostęp: 11.09.2016).

Krajewska A., Szkolnictwo wyższe w kontekście potrzeb i problemów rynku pracy, [w:] R. Gerlach (red.), Edukacja wobec rynku pracy. Realia - możliwości - perspektywy, Wydawnictwo Akademii Bydgoskiej im. Kazimierza Wielkiego, Bydgoszcz 2003.

Matysiak A., Kształcenie ustawiczne w Polsce. Korzyści i bariery rozwoju, Polskie Forum Strategii Lizbońskiej, Niebieskie Księgi nr 8, Wydawnictwo Instytut Badań nad Gospodarką Rynkową, Gdańsk 2003.

Melosik Z., Kultura popularna i tożsamośc młodziezy, Wydawnictwo IMPULS, Kraków 2013.

Młodzi na rynku pracy. Pod lupa. Raport - Sytuacja młodych ba rynku pracy z perspektywy przedsiębiorstw MŚP, Wydawnictwo PARP, Warszawa 2014.

Pieniążek W., Przybył C., Pacuska M., Chojecki J., Huras P., Pałka S., Ratajczyk J., Rudolf A., Analiza kwalifikacji i kompetencji kluczowych dla zwiększenia szans absolwentów na rynku pracy. Raport końcowy, Wydawnictwo NCBiR, Warszawa 2014.

Raport o stanie edukacji 2012. Licza się efekty, Wydawnictwo IBE, Warszawa 2013.

${ }^{16}$ D. Turek, Kompetencje osób młodych na rynku pracy-oczekiwania pracodawców, „E-mentor”, $\mathrm{nr} 3(60) / 2015$, http://www.e-mentor.edu.pl/artykul/index/numer/60/id/1179 (dostęp: 26.09.2014), s. 11. 
Raport Dwa światy. Kompetencje przyszłości 2014, http://kariera.kozminski.edu.pl/ fileadmin/kariera.kozminski.edu.pl/Raporty/RAPORT KOMPETENCJE PRZYSZLOSCI - pracodawca.pdf (dostęp: 20.05.2017).

Studenci nie znaja oczekiwań pracodawców [Raport PARP], http://www.hrtrendy. pl/2014/06/24/studenci-nie-znaja-oczekiwan-pracodawcow-raport-parp/ (dostęp: 26.09.2014).

Turek D., Kompetencje osób młodych na rynku pracy - oczekiwania pracodawców, „E-mentor”, nr 3(60)/2015, http://www.e-mentor.edu.pl/artykul/index/numer/60/id/1179 (dostęp: 26.09.2014).

\title{
Between University and Labour Market - Youth's perspectives
}

\begin{abstract}
Process of entering to the contemporary labour market requires adequate preparation. The efficient functioning in this complex system requires, first and foremost, changes in thinking about the safety of employment. Moreover, it requires the attitude to work connected with permanent aquisition of new skills characterizing the individuality of employee in a given area of occupational activity. The ever-changing labour market forcing the constantly improvement, preferably in different areas at the same time. It requires flexibility, mobility and creativity. Employee must accept these changes and challenges and try to meet the demands of employers. The paper outlines the contemporary realities of preparation for entering the labour market and the possibilities of functioning on it.
\end{abstract}

Keywords: higher education, labour market, young generations, employment.

About the author: dr hab. Daniel Kukla - Author of dozens of scientific and methodological papers on career counselling published in Poland and abroad in congress languages. Participant of international and national conferences. Actively cooperating with many academic centres in Poland. Reviewer of scientific and methodological studies. Member of research teams in international projects concerning professional activation and educational-career counselling for various groups of recipients in cooperation, among others, with Ruprecht-Karls-Universitat Heidelberg and Hochschule der Bundesagentur für Arbeit in Mannheim (Germany). Scientific research interests are centred around the importance of working in the life of a young person and the role that modern education and career counselling plays in the designing the vocational future of a person, and thus, in the transition from education to the labour market. 


\author{
Marta Motow-Czyż \\ Akademia im. Jana Długosza w Częstochowie \\ motowka@interia.pl
}

\author{
Irena Motow**
}

Akademia Humanistyczno-Ekonomiczna w Łodzi

i.motow@interia.pl

\title{
Ocena świadomości rodziców w zakresie występowania wad postawy ciała u dzieci
}

\begin{abstract}
Streszczenie: Jednym z warunków normalnego rozwoju i zdrowia dziecka jest kształtowanie prawidłowej postawy ciała. Szybki rozwój współczesnej cywilizacji niesie ze sobą przeobrażenia w środowisku otaczającym dziecko, przyczyniając się do powstawania wad postawy. Ważnym elementem profilaktyki i leczenia w zapobieganiu wadom postawy jest dbałość o dobrą postawę. W okresie dzieciństwa, w dużej mierze za jej dbałość odpowiada rodzic, którego świadomość w zakresie problematyki wad postawy nie zawsze jest wystarczająca. Celem artykułu będzie analiza świadomości rodziców w zakresie wad postawy w badaniach własnych.
\end{abstract}

Słowa kluczowe: prawidłowa postawa ciała, wada postawy, rola rodziców, skolioza, płaskostopie

* Dr Marta Motow-Czyż - adiunkt w Zakładzie Nauk Biologiczno-Medycznych w Instytucie Wychowania Fizycznego Turystyki i Fizjoterapii Akademii im. Jana Długosza w Częstochowie. Fizjoterapeuta z 14-letnim doświadczeniem prowadzący rehabilitację dzieci i młodzieży w zakresie wad postawy ciała. Pracownik naukowy realizujący badania w zakresie wad postawy ciała oraz skuteczności metod rehabilitacyjnych w leczeniu schorzeń narządu ruchu.

** Dr hab. Irena Motow, prof. AHE - profesor nadzwyczajny Akademii Humanistyczno-Ekonomicznej w Łodzi. Kierownik Katedry Pedagogiki Resocjalizacyjnej i Profilaktyki Społecznej. Pedagog z 25-letnim stażem pracy z młodzieżą przestępczą, realizujący badania naukowe w zakresie integracji niedostosowanych społecznie po opuszczeniu instytucji resocjalizacyjnych. 


\section{Wprowadzenie}

W obecnych czasach sporo dzieci cierpi z powodu nieprawidłowej postawy ciała. Stanowi to ogromny problem społeczny i przyczynia się do szerzenia się wad postawy. Młody człowiek w XXI wieku narażony jest na wiele czynników środowiskowych, które często mają negatywny wpływ na postawę ciała. Wśród nich wymienia się małą aktywność fizyczną dzieci, siedzący tryb życia, zbyt duże obciążenie tornistrem na plecach oraz szereg innych, związanych z ergonomią pracy młodego człowieka. To wszystko powoduje osłabienie mięśni, które jest wynikiem hipokinezji - niedoboru ruchowego. Jak podają Ełła Bulicz i Igor Murawow, hipokinezja w swym destrukcyjnym działaniu nie ogranicza się tylko do włókien kurczliwych, ale negatywnie wpływa na rdzenne włókna czuciowe i ruchowe ${ }^{1}$. W sytuacji, gdy brak jest stymulacji organizmu poprzez ruch, następuje osłabienie procesów troficznych, a tym samym osłabienie mięśni, więzadeł i ścięgien, które odpowiadają za prawidłową postawę ciała. W wyniku osłabienia tych procesów dochodzi do zaburzeń metabolicznych związanych z pracą mięśni, co powoduje pojawianie się nieprawidłowości w obrębie postawy ciała.

Aby młody organizm wykształcił w sobie chęć do ruchu, istotna jest edukacyjna rola rodzica w tym kierunku. Styl życia i zachowania zdrowotne prezentowane przez rodziców w okresie najmłodszym dziecka (przedszkolnym i wczesnoszkolnym), kształtują jego postawy zdrowotne, które w wieku dorosłym mogą przejawiać się spowolnieniem procesów starzenia oraz wydłużeniem życia. Dlatego to rodzic, aby mieć zdrowe i silne dziecko, ma obowiązek zachęcać je do ruchu i unikać sytuacji, które mogą wpływać niekorzystnie na postawę ciała. Niestety, nie zawsze ten obowiązek jest przez rodziców spełniany. Trafność i efektywność stosowania aktywności fizycznej przez rodziców często uzależniona jest między innymi od: ich poziomu wykształcenia i świadomości w zakresie omawianej problematyki, statusu społeczno-ekonomicznego rodziny i jej liczebności, wieku - zarówno rodziców, jak i innych członków rodziny, a także kondycji zdrowotnej i psychicznej rodziny oraz ewentualnie nałogów występujących wśród rodziców ${ }^{2}$. Dodatkowo takie czynniki, jak szybkie tempo życia, przeciążenie dziecka zajęciami pozalekcyjnymi, zbyt długie siedzenie dziecka przed komputerem czy telewizorem, pozostawiają za sobą skutki w postaci wad postawy.

W obecnych czasach wady postawy można nazwać chorobami cywilizacyjnymi. Jak pokazują badania przeprowadzone w 2005 roku przez Elżbieta Olszewską i Dorota Trzcińską w ramach bilansu zdrowia dziecka, częstość występowania wad postawy

${ }^{1}$ E. Bulicz, I. Murawow, Wychowanie Zdrowotne. Zdrowie człowieka i jego diagnostyka. Efekty zdrowotne aktywności ruchowej, Radom 2002, s. 357.

2 A. Pocztarska-Dec, Rola rodziców i nauczycieli wychowania fizycznego w ksztaltowaniu postaw prozdrowotnych, „Rozprawy społeczne” 2011, s. 101-11. 
wśród tej grupy społeczeństwa ciągle się zwiększa³. Niesie to za sobą pojawienie się szeregu problemów w obrębie układu ruchu u tej grupy dzieci już po osiągnięciu dorosłości. Dlatego też istotne jest rozmawianie o tym problemie nie tylko w obrębie szkół czy przedszkoli, ale również z samymi rodzicami. Często poprzez poinformowanie ich o objawach, jakie mogą towarzyszyć wadom postawy, można umożliwić rodzicom zmniejszenie ryzyka ich pogłębienia czy wystąpienia u dzieci.

\section{Wady postawy ciała występujące u dzieci}

W rozumieniu naukowym wady postawy to konkretne odstępstwa postawy ciała od ogólnie przyjętych kryteriów, uznanych za prawidłowe. Jak podaje Taduesz Kasperczyk, wady postawy to odchylenia od ogólnie przyjętych cech prawidłowej postawy, właściwej dla danej kategorii wieku, płci i typu budowy . Ewa Zeyland-Malawka definiuje nieprawidłową postawę jako kształt ciała, wynikający z budowy i nawykowego lub przymusowego usytuowania poszczególnych części ciała, [...] niekorzystny dla orga$n i z m u^{5}$.Główną cechą wad postawy jest występująca asymetryczność w płaszczyźnie czołowej. Asymetryczność ta dotyczy barków, łopatek, ramion, trójkątów talii, linii wyrostków kolczystych kręgosłupa, linii bioder, okolic krętarzy większych, ustawienia kolan i stóp. Znajomość kilku tych cech przez rodziców i obserwacja dziecka mogą przyczynić się do szybszego wychwycenia wady, a tym samym do szybszej korekcji. Wśród wad postawy ciała wyróżnia się wiele zaburzeń. Autor zdecydował się na omówienie tych, które są najczęściej spotykane w wieku dziecięcym. Należą do nich: plecy płaskie, plecy okrągłe, skoliozy, kolana koślawe, kolana szpotawe, płaskostopie.

Plecy płaskie to wada pojawiająca się w płaszczyźnie czołowej. Charakteryzuje się spłaszczeniem krzywizn fizjologicznych kręgosłupa, co spowodowane jest zmniejszeniem przodopochylenia miednicy. Typowymi cechami charakteryzującymi tę wadę są: opadnięte barki, łopatki odstające, klatka piersiowa płaska. Ponadto dochodzi do słabego rozwinięcia mięśni grzbietu oraz do obniżenia narządów wewnętrznych. W wyniku zmniejszenia przodopochylenia miednicy dochodzi do odczuwanych często u osób z tym schorzeniem bóli głowy. Spowodowane jest to zaburzeniem funkcji amortyzacyjnej kręgosłupa poprzez zmniejszenie jego krzywizn fizjologicznych. Ponadto zmniejszenie tych krzywizn niesie za sobą zwiększenie przeciążeń kręgosłupa, czego efektem mogą być zmiany zwyrodnieniowe pojawiające się w wieku dorosłym. Według S. Tuzinka przyczyny tej wady lekarze upatruja w siedzącym trybie życia, który powoduje na skutek hipokinezji zmniejszenie potencjału energetycznego organizmu

${ }^{3}$ E. Olszewska, D. Trzcińska, Postawa ciała dzieci i młodzieży w różnych okresach rozwojowych, [w:] K. Górniak (red.), Korektywa i kompensacja zaburzeń w rozwoju fizycznym dzieci i młodzieży, Wydawnictwo AWF ZWWF, Biała Podlaska 2005, s. 66-76.

4 T. Kasperczyk, Wady postawy ciała diagnostyka i leczenie, Kraków 2004, s. 10.

${ }^{5}$ E. Zeyland-Malawka, O kryteriach oceny postawy, [w:] J. Ślężyński (red.), Postawa ciała człowieka i metody jej oceny, Katowice 1992, s. 13. 
i osłabienie mięśni ${ }^{6}$. W wyniku omawianych zaburzeń dochodzi do osłabienia i rozciągnięcia mięśni grzbietu odcinka piersiowego oraz mięśni unoszących barki, w szczególności mięśnia naramiennego i górnej części mięśnia czworobocznego. Wadzie tej towarzyszy również przykurczenie mięśni brzucha. Dodatkowo (w wyniku zachodzących patologicznych procesów) dochodzi do rozciągnięcia mięśni zginających udo i przykurczenia mięśni prostujących udo.

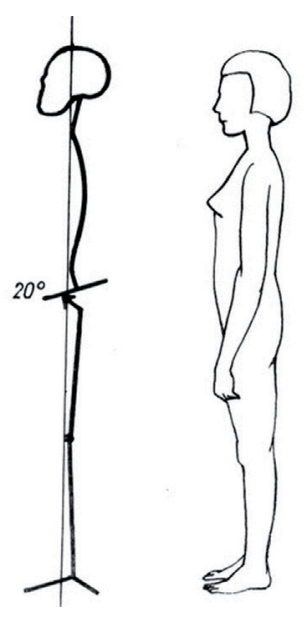

Rys. 1. Plecy płaskie

Źródło: Specjalizowane Systemy Elektroniczne Obrazowej Diagnostyki Medycznej, http://www.cq.com.pl/n gl wady.html (dostęp: 29.06.2017)

Kolejna wada w płaszczyźnie czołowej to plecy okrągłe. Charakteryzuje się pogłębieniem krzywizn fizjologicznych kręgosłupa, najczęściej w odcinku piersiowym (tzw. hiperkifozą). W sytuacji, w której wada dotyczy całego kręgosłupa, mamy do czynienia z kifozą totalną. Sylwetka osoby z plecami okrągłymi charakteryzuje się wysuniętą głową, wysuniętymi do przodu barkami, rozsunięciem łopatek oraz spłaszczeniem i zapadnięciem klatki piersiowej, które może powodować upośledzenie funkcji oddechowej klatki piersiowej. Przyczyn pojawiania się pleców okrągłych upatruje się w dystonii mięśniowej i zaburzeniach równowagi. W plecach okrągłych osłabieniu i rozciągnięciu ulegają:

- mięśnie prostownika grzbietu odcinka piersiowego,

- mięśnie karku,

- mięśnie ściągające łopatki (czworoboczny, równoległoboczny, najszerszy grzbietu).

Mięśniami nadmiernie napiętymi i często przykurczowymi w tej wadzie są:

- mięśnie piersiowe (wielki i mały),

- mięsień zębaty przedni.

${ }^{6}$ S. Tuzinek, T. Biniaszewski, A. Ratyńska, Podstawy teorii i metodyki gimnastyki kompensacyjno-korekcyjnej, Radom 2010, s. 37. 

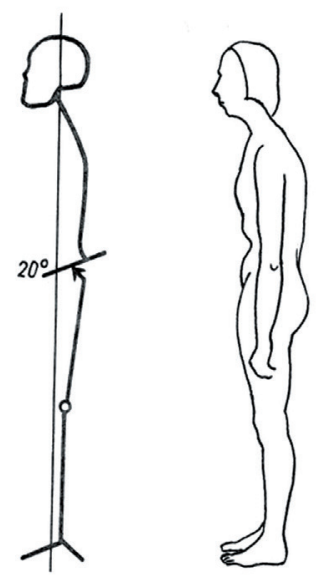

Rys. 2. Plecy okrągłe

Źródło: Specjalizowane Systemy Elektroniczne Obrazowej Diagnostyki Medycznej, http://www.cq.com.pl/n gl wady.html (dostęp: 29.06.2017)

Wadami, które charakteryzuje wielopłaszczyznowość, są skoliozy. Cechuje je występowanie zaburzeń w obrębie płaszczyzny strzałkowej, czołowej i poprzecznej. Alicja Romanowska podaje, że

skoliozy to skrzywienia kręgosłupa charakteryzujące się odchyleniem osi anatomicznej kręgosłupa (wyrostków kolczystych) lub jego odcinka, które pociąga za sobą zmiany wtórne w narządzie ruchu, klatce piersiowej i narządach wewnętrznych ${ }^{7}$.

W wyniku odchylenia dochodzi w płaszczyźnie czołowej do wygięcia kręgosłupa w prawo lub w lewo, w płaszczyźnie strzałkowej do spłaszczenia lub pogłębienia wygięci kifotycznych lub lordotycznych, zaś w płaszczyźnie poprzecznej do rotacji kręgu, która przyczynia się do pojawienia się garbu żebrowego w odcinku piersiowym i wału lędźwiowego w odcinku lędźwiowym. Stwierdzenie wystąpienia wymienionych zmian wymaga profesjonalnego przygotowania. Istnieją jednak - w przypadku skolioz - takie cechy, które mogą zostać uchwycone przez rodziców i przyczynić się do szybszego wykrycia wady. Do tych cech należą asymetryczne barki, asymetryczne łopatki oraz asymetryczne trójkąty talii.

\footnotetext{
${ }^{7}$ A. Romanowska, Wychowanie do postępowania korekcyjnego, Płock 2011, s. 76.
} 

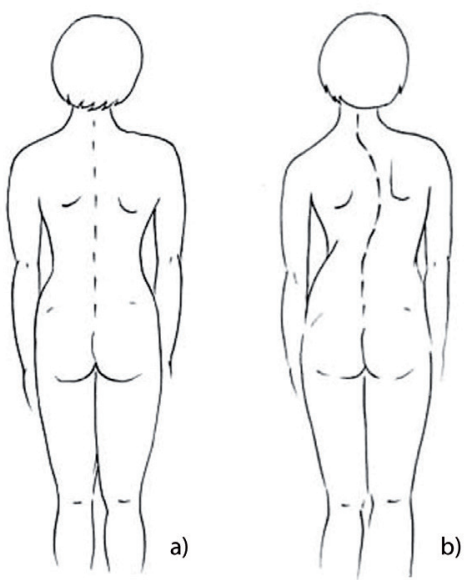

Rys. 3. Skolioza: a) postawa prawidłowa, b) skolioza

Źródło: Postawa prawidłowa, skolioza - źródło własne.

Wadami w obrębie kolan spotykanymi dość często u dzieci są kolana koślawe i szpotawe. Pierwsze z nich charakteryzują się oddaleniem kostek przyśrodkowych stopy od siebie w pozycji stojącej o więcej niż $3 \mathrm{~cm}$. Szpotawość jest natomiast odwrotnością koślawości. W jej wyniku pomiędzy kłykciami przyśrodkowymi w obrębie stawu kolanowego dochodzi do oddaleni większego niż $3 \mathrm{~cm}$.
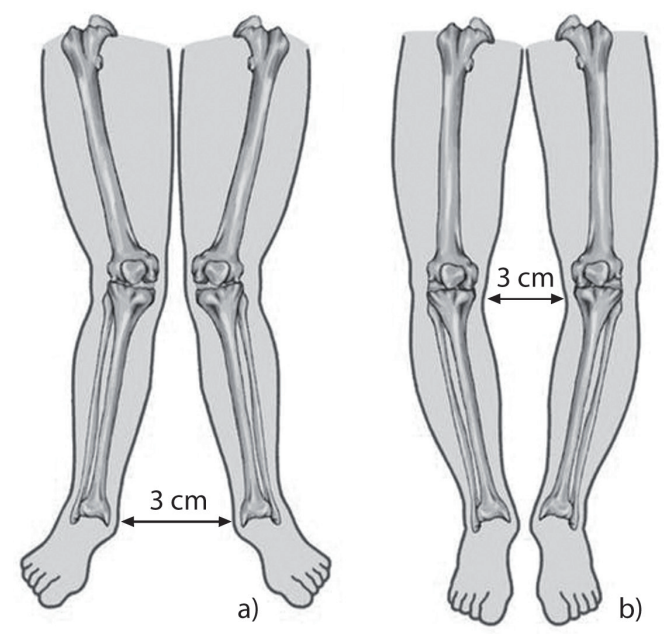

Rys. 4. Wady kolan: a) koślawość, b) szpotawość

Źródło: Wybrane stany patologiczne aparatu stawowego, https://zobaczzrozum.wordpress.com/2013/08/14/wybrane-stany-patologiczne-aparatu-stawowego/(dostęp: 29.06.2017) 
Płaskostopie to wada, która charakteryzuje się obniżeniem łuku podłużnego stopy. Obniżenie to dotyczy łuku przyśrodkowego stopy. Może również dochodzić do obniżenia łuku poprzecznego stopy, choć z reguły jest to efekt długotrwałego występowania i nieleczenia wady. Dodatkowo płaskostopiu może towarzyszyć koślawość pięty, która często łączy się z koślawością kolan, a także szybkie męczenie i bolesność stóp i łydek.

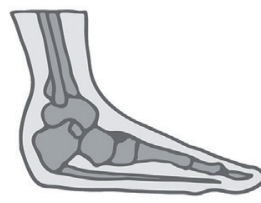

a)

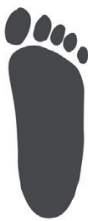

Rys. 5. Wady stóp: a) stopa płaska, b) stopa płasko-koślawa

Źródło: Badanie wysklepienia stopy - płaskostopia, http://ewa.mirocha.w.interia.pl/planto/planto.htm (dostęp: 29.06.2017)

\section{Cel badań}

Powszechność występowania wad postawy skłania do poszukiwania sposobów zapobiegania im. Biorąc pod uwagę obniżanie się wieku występowania wad postawy u dzieci i obecny tryb życia młodych ludzi, zainteresowano się najbliższym środowiskiem wychowawczym. Dlatego też celem badań była analiza świadomości rodziców w zakresie wad postawy, ponieważ to oni, jako najbliższe środowisko wychowawcze, kształtują nawyki i zachowania swoich dzieci.

\section{Materiał i metodyka badań własnych}

Grupę badawczą stanowili rodzice dzieci w wieku od 3 do 16 roku życia. W badaniach brało udział 76 mieszkających w miastach rodziców, wśród których było 60 kobiet i 16 mężczyzn w wieku od 20 do 50 lat. Wśród badanych 62 osoby posiadały wyższe wykształcenie, 11 - średnie, a 3 - zasadnicze.

Tabela 1. Wiek rodziców biorących udział w badaniu

\begin{tabular}{|l|c|c|}
\hline \multicolumn{1}{|c|}{ Wiek badanych } & Liczba badanych & $(\%)$ \\
\hline $20-30$ & 10 & 13,2 \\
\hline $31-40$ & 47 & 61,8 \\
\hline $41-50$ & 13 & 17,1 \\
\hline 51 i więcej & 6 & 7,9 \\
\hline Razem & 76 & 100,0 \\
\hline
\end{tabular}

Źródło: badania własne 
Do zrealizowania założonego celu posłużono się sondażem diagnostycznym. Przy pomocy ankiety i sporządzonego $\mathrm{w}$ tym celu kwestionariusza zgromadzono odpowiednią ilość wiedzy do przeprowadzenia analizy omawianego problemu.

\section{Wyniki}

Wśród badanych dominującą grupę (84,2\%) stanowili rodzice, którzy wskazali, że ich dziecko było badane pod kątem wad postawy. U większości dzieci ankietowanych rodziców (52\%) występują wady postawy, 47,4\% badanych rodziców stwierdziło brak wady postawy wśród swoich dzieci. Jako osobę, która diagnozowała wady postawy najczęściej, rodzice wskazywali lekarza $(42,1 \%)$, w następnej kolejności fizjoterapeutę $(18,4 \%)$ oraz pielęgniarkę $(11,8 \%)$. Na podstawie zebranego materiału stwierdzono, że 46,1\% rodziców wskazało, że ich dziecko uczęszcza na zajęcia korekcyjno-kompensacyjne.

Badając świadomość rodziców na temat wad postawy, sprawdzano ich podstawową wiedzę na ten temat. Większość respondentów $(94,7 \%)$ potrafiła określić, czym jest wada postawy, jedynie 5,3\% nie posiadało wiedzy na ten temat. Ponadto większość rodziców $(80,3 \%)$ wskazało, że wady postawy to zaburzenia w postawie prawidłowej, $13,2 \%$ było zdania, że wady postawy to tylko skrzywienia kręgosłupa, a 6,6\% wskazywało, że wady postawy są chorobami. Na szczególną uwagę zasługują wypowiedzi rodziców, które definiują wady postawy jako skrzywienia kręgosłupa. Taki sposób definiowania może wynikać z tego, że często w mediach słuchają wypowiedzi o wadach postawy w kontekście skoliozy. $\mathrm{Z}$ tego względu wszystkie wady postawy mogą być kojarzone przez tę grupę rodziców jako wady w obrębie kręgosłupa.

Analizując wiedzę rodziców na temat przyczyn powodujących pojawienie się wady postawy, najczęściej $(88,2 \%)$ rodzice wskazywali przyjmowanie nieprawidłowej postawy ciała przez dziecko. Jednocześnie $75 \%$ stwierdziło też, że przyczyną może być noszenie nieprawidłowego obuwia oraz większość (69,7\%) badanych wskazała, że istotnym czynnikiem może być noszenie przez dzieci ciężkich przedmiotów. Należy zaznaczyć, że jedynie 32,9\% rodziców oświadczyło, że przyczyną pojawienia się wady postawy może być nieprawidłowe żywienie. Badania naukowe alarmują natomiast, że nadwaga i otyłość oraz - rzadziej - niedowaga są głównymi przyczynami wad postawy ciała 8 .

Poza wcześniej wspomnianymi aspektami badano wiedzę rodziców na temat rodzajów wad postawy. Najbardziej znaną przez rodziców wadą postawy są skoliozy $(82,9 \%)$, na drugim miejscu jest płaskostopie $(76,3 \%)$, a na trzecim plecy okrągłe $(73,7 \%)$. Wysoki odsetek rodziców posiadających wiedzę na temat skolioz może

${ }^{8}$ J. Błaszczyk, J. Cieślinska-Świder, M. Plewa, B. Zahorska-Markiewicz, A. Markiewicz, Effects of excessive body weight on postural control, "Journal of Biomechanics", nr 42(9)/2009, s. 1295-1300. 
wynikać z tego, że obecnie wszelkie media, lekarze i badania naukowe wskazują, że występowanie tej wady u dzieci należy traktować jako poważny problem społeczny.

Analizując informacje pozyskane od respondentów, zauważono, że większość rodziców $(98,7 \%$.) - w celu likwidacji wad postawy - skierowałoby dziecko na zajęcia korekcyjno-kompensacyjne. Ponadto wielu rodziców $(86,8 \%)$ stwierdziło, że w celu likwidacji wad należy ćwiczyć z dzieckiem w domu, mniej $(67,1 \%)$ wskazało, że powinno się wykazywać aktywność fizyczną, a tylko niektórzy (31,6\%) respondenci uważali, że w celu likwidacji wady należy stosować właściwą dietę.

W podawanych przez rodziców informacjach na temat ich edukacji w zakresie występowania wad postawy u dzieci, wszyscy (100\%) podkreślali, że w przedszkolach i szkołach powinny być prowadzone dla rodziców szkolenia w tym zakresie, szczególnie w kwestii sposobów zapobiegania i wychwytywania wad postawy ciała. Prowadzenie tego typu zajęć pozwoliłoby rodzicom szybciej zareagować w sytuacji wystąpienia jakichś zmian w obrębie postawy ciała ich dzieci.

\section{Wnioski}

Na podstawie przeprowadzonych badań własnych omawianego problemu skonstruowano następujące wnioski:

1. W badanej grupie większość respondentów wskazała, że ich dzieci mają wady postawy, co potwierdzają liczne badania naukowe na ten temat ${ }^{9}$.

2. Ankietowani rodzice potrafią określić, czym są wady postawy i jakie są przyczyny ich powstawania. Niepokojący jest fakt, że część rodziców nie widzi przyczyny pojawiania się wad postawy w nieprawidłowym żywieniu, mimo doniesień naukowych na ten temat. Dodatkowa edukacja rodziców i opiekunów dzieci w tym zakresie jest niezbędna.

3. Rodzice posiadają również stosowną wiedzę dotyczącą tego, jak należy postępować w celu likwidacji wady. Większość uważa, że przede wszystkim powinno się wykorzystać w tym celu zajęcia korekcyjno-kompensacyjne; badani wskazują też na ćwiczenia z dzieckiem w domu. Instruktorzy zajęć korekcyjnych stwierdzają natomiast, że rodzice, mimo że wiedzą o takiej potrzebie, nie ćwiczą z dzieckiem w domu.

4. Wszyscy respondenci są zdania, że szkolenia dla rodziców w zakresie wad postawy ciała powinny być prowadzone w placówkach edukacyjnych (przedszkolach, szkołach). Dzięki temu rodzice dowiedzieliby się więcej na temat sposobów wykrywania wad postawy czy ich przyczyn, co niewątpliwie zwiększyłoby ich świadomość w zakresie omawianego problemu.

9 R. Janiszewska, S. Tuzinek, S. Nowak, A. Ratyński, T. Biniaszewski, Abnormalities of posture in 6-12 year-old children - pupils of primary schools from Radom - a pilot study, "Probl Hig Epidemiol", nr 90(3)/2009, s. 342-346. 


\section{Zakończenie}

Procent dzieci w wieku rozwojowym, które mają zaburzenia postawy ciała, stale wzrasta. Wynika to ze stylu życia młodego człowieka, który często od wyjścia na dwór i gry w piłkę woli gry na komputerze czy spędzanie czasu przed telewizorem. Badania pokazują, że średnio 50-60\% populacji (w zależności od regionu) ma wady postawy ${ }^{10}$. Istotne jest zatem wskazanie rodzicom, że oni jako pierwsi powinni zwracać uwagę na postawę ciała własnego dziecka i w przypadku zauważenia nieprawidłowości zwrócić się do lekarza. Ten stan rzeczy wymaga posiadania przez rodziców umiejętności określania, które z występujących nieprawidłowości świadczą o wadzie postawy ciała.

Podejmując próbę oceny uzyskanych wyników należy zwrócić uwagę, że głównym celem badania było określenie świadomości rodziców w zakresie wad postawy ciała. Analiza uzyskanych danych pozwoliła stwierdzić, że świadomość ta jest duża. Niemniej jednak, należy zwrócić uwagę na fakt, że rodzice nadal są chętni do szkoleń w zakresie poznawania przyczyn wad postawy oraz ich profilaktyki.

\section{Bibliografia}

Bulicz E., Murawow I., Wychowanie Zdrowotne. Zdrowie człowieka i jego diagnostyka. Efekty zdrowotne aktywności ruchowej, Wydawnictwo Politechnika Radomska, Radom 2002.

Błaszczyk J., Cieślinska-Świder J., Plewa M., Zahorska-Markiewicz B., Markiewicz A., Effects of excessive body weight on postural control, "Journal of Biomechanics", nr 42(9)/2009, s. 1295-1300.

Janiszewska R., Tuzinek,S., Nowak S., Ratyński A., Biniaszewski T., Abnormalities of posture in 6-12 year-old children - pupils of primary schools from Radom a pilot study "Probl Hig Epidemiol", nr 90(3)/2009, s. 342-346.

Kasperczyk T., Wady postawy ciała diagnostyka i leczenie, KASPER, Kraków 2004.

Olszewska E., Trzcińska D., Postawa ciała dzieci i młodzieży w różnych okresach rozwojowych, [w:] K. Górniak (red.), Korektywa i kompensacja zaburzeń w rozwoju fizycznym dzieci i młodzież, AWF ZWWF, Biała Podlaska 2005.

Pocztarska-Dec A., Rola rodziców i nauczycieli wychowania fizycznego $w$ kształtowaniu postaw prozdrowotnych, „Rozprawy Społeczne”, nr 1(V)/2011, s. 101-106. Rekomendacja Zespołu Ekspertów, Profilaktyki wad postawy u dzieci i młodzieży w środowisku nauczania i wychowania, 2009; http://www.mz.gov.pl/wwwfiles/ ma struktura/docs/profil wad postawy 24022010.pdf (dostęp 29.06.2017).

${ }^{10}$ Rekomendacja Zespołu Ekspertów, Profilaktyki wad postawy u dzieci i młodzieży w środowisku nauczania i wychowania, 2009. 
Romanowska A., Wychowanie do postępowania korekcyjnego, Wydawnictwo Korepetytor, Płock 2011.

Tuzinek S., Biniaszewski T., Ratyńska A., Podstawy teorii i metodyki gimnastyki kompensacyjno-korekcyjnej, Politechnika Radomska, Radom 2010.

Zeyland-Malawka E., O kryteriach oceny postawy, [w:] J. Ślężyński (red.), Postawa ciała człowieka i metody jej oceny, AWF Katowice, Katowice 1992.

\title{
Assessment of parents' awareness of the occurrence of postural defects
}

Abstract: One of the conditions necessary for the proper growth and maintaining child's health is developing their correct posture. The rapid progress of modern civilization carries changes in environment and contributes to abnormal curvature of the spine. The important part of prevention and treatment of posture's defect is to take care of a good posture. During childhood parents, whose awareness of the issues of defect of posture is not always sufficient, are responsible for care of that. The objectives of the article will be an analysis of the consciousness of parents in terms of posture defects in research of their own.

Keywords: correct postur, defect of posture, the role of the parents, scoliosis, flat feet

\begin{abstract}
About the author: Dr hab. Irena Motow, prof. AHE - Associate Professor at the Humanities and Economics Academy in Lodz. Head of the Department of Pedagogy of Resocialization and Social Prevention. Pedagogue with 25 years of work experience with juvenile delinquency, conducting research on socially unsuitable integration after leaving social rehabilitation institutions.

Dr Marta Motow-Czyz - assistant Professor at the Department of Biological and Medical Sciences at the Institute of Physical Education of Tourism and Physiotherapy Jan Długosz University in Czestochowa. Physiotherapist with 14 years of experience in rehabilitation of children and adolescents in terms of posture defects. Researcher performing research on body posture defects and effectiveness of rehabilitation methods in the treatment of locomotive organs diseases.
\end{abstract}




\title{
Irena Motow*
}

Akademia Humanistyczno-Ekonomiczna w Łodzi

i.motow@interia.pl

\section{Marta Motow-Czyz ${ }^{* *}$}

Akademia im. Jana Długosza w Częstochowie

motowka@interia.pl

\section{Zasoby adaptacyjne młodzieży zagrożonej wykluczeniem społecznym}

\begin{abstract}
Streszczenie: Celem artykułu jest przedstawienie zasobów adaptacyjnych młodzieży zagrożonej wykluczeniem społecznym. Skoncentrowano się na klasyfikacji zasobów S. E. Hobfolla. Przebadano 50 osobową grupę podopiecznych świetlicy środowiskowej w Bytomiu. Wyniki przeprowadzonych badań wskazały, że badana grupa posiada bardzo nieliczne zasoby sprzyjające pozytywnej adaptacji.
\end{abstract}

Słowa kluczowe: Zasoby adaptacyjne, wykluczenie społeczne, adaptacja społeczna.

Młodość to czas, w którym człowiek odczuwa największą potrzebę akceptacji i wsparcia, kiedy najbardziej pragnie być wysłuchany i kochany.

Jan Paweł II

\footnotetext{
* Dr hab. Irena Motow, prof. AHE - profesor nadzwyczajny Akademii Humanistyczno-Ekonomicznej w Lodzi. Kierownik Katedry Pedagogiki Resocjalizacyjnej i Profilaktyki Społecznej. Pedagog z 25 letnim stażem pracy z młodzieżą przestępczą, realizujący badania naukowe w zakresie integracji niedostosowanych społecznie, po opuszczeniu instytucji resocjalizacyjnych.

* Dr Marta Motow-Czyż - adiunkt w Zakładzie Nauk Biologiczno-Medycznych w Instytucie Wychowania Fizycznego, Turystyki i Fizjoterapii Akademii im. Jana Długosza w Częstochowie. Fizjoterapeuta z 14 letnim doświadczeniem, prowadzący rehabilitację dzieci i młodzieży w zakresie wad postawy ciała. Pracownik naukowy realizujący badania w zakresie wad postawy ciała oraz skuteczności metod rehabilitacyjnych w leczeniu schorzeń narządu ruchu.
} 
Od lat na gruncie nauk społecznych wiele uwagi poświęca się zjawisku wykluczenia społecznego i poszukuje się możliwości profilaktyki w tym zakresie. Kwintesencją wykluczenia jest uniemożliwienie jednostce lub grupie szans na życie „w pełni ludzkie”, tzn. zabezpieczone od ubóstwa i zgodne z normami obowiązującymi w środowisku ekologicznym. Dzieci i młodzież ze środowisk zaniedbanych i zmarginalizowanych są najbardziej na nie narażone. Konsekwencją dorastania w środowiskach wykluczonych są uciążliwości i niepowodzenia adaptacyjne w życiu dorosłym, które implikują problemy ogólnospołeczne. Spolaryzowanie społeczeństw wynikające z ekonomizacji przekłada się na tworzenie barier w integracji społecznej. Mimo tych przeciwieństw, badania inspirowane koncepcją resilience wskazują na istnienie procesów równoważenia i redukowania niekorzystnych zjawisk utrudniających prawidłową adaptację ${ }^{1}$. Zasoby adaptacyjne stanowią istotny czynnik uruchamiający te procesy.

\section{Adaptacja, zasoby adaptacyjne. Dyskusja pojęciowa}

Termin „,adaptacja” pojawia się w wielu okolicznościach. Używany jest przez laików i przedstawicieli różnych dyscyplin naukowych, głównie psychologów, pedagogów i socjologów. Wymiar pojęciowy terminu jest niejednoznaczny. Słowo samo w sobie pochodzi z języka łacińskiego (adaptatio) i oznacza przekształcenie, przeróbkę, przystosowanie do innego użytku. Klasyczne rozumienie odnosi się do nauk biologicznych. W teorii homeostazy Claude’a Bernarda czy Waltera B. Cannona adaptacja ujmowana jest jako stan równowagi środowiska wewnętrznego organizmu, utrzymywany dzięki odpowiedniej koordynacji i regulacji procesów życiowych. W Słowniku wyrazów obcych i zwrotów obcojęzycznych $z$ almanachem Władysław Kopaliński zdefiniował adaptację jako proces przystosowania organizmów w ciągu ich rozwoju ewolucyjnego do zmienionych warunków środowiska ${ }^{2}$. To kryterium biologiczne jest niewystarczające w odniesieniu do człowieka.

Stanowisko biopsychologiczne, dotyczące aktywności organizmu w relacji z otoczeniem, reprezentuje Janina Doroszewska, stwierdzając, że zewnątrzustrojowe procesy przystosowawcze człowieka przebiegają dwutorowo jako:

a) adaptacja do środowiska fizycznego człowieka,

b) adaptacja do otoczenia społecznego ${ }^{3}$.

${ }^{1}$ H. Sęk, Wsparcie społeczne jako kategoria zasobów i wieloznaczne funkcje wsparcia, [w:] Z. Juczyński, N. Ogińska-Bulik (red.), Zasoby osobiste i społeczne sprzyjające zdrowiu jednostki, Wydawnictwo Uniwersytetu Łódzkiego, Łódź 2003, s. 17-32.

${ }^{2}$ Wł. Kopaliński, Słownik wyrazów obcych i zwrotów obcojęzycznych z almanachem, Oficyna Wydawnicza Rytm, Warszawa 2006, s. 13.

${ }^{3}$ J. Doroszewska, Pedagogika specjalna, Wydawnictwo Ossolineum, Wrocław 1995, s. 19. 
Szczególną rolę w badaniach nad adaptacją odegrał Jean Piaget ${ }^{4}$. W psychologicznej teorii rozwoju osobowości podkreślał, że procesy przystosowawcze zachodzą wówczas, gdy jednostka przekształca się w stosunku do wymogów wysuwanych przez środowisko w którym funkcjonuje. Uważał, że adaptacja implikuje rozwój jednostki. W teorii Abrahama Maslowa (hierarchia potrzeb) adaptacja wiąże się z zaspakajaniem potrzeb psychicznych człowieka. Przystosowanie określane jest jako umiejętność zaspokajania przez osobnika, w warunkach danego środowiska, potrzeb rozumianych jako dążenie do określonych celów, zarówno zdobywczych, jak i obronnych ${ }^{5}$.

W naukach społecznych interpretowanie terminu „adaptacja” łączy się z nadaniem mu funkcji regulatora czynników determinujących rozwój i zachowanie jednostki. Florian Znaniecki traktuje adaptację jako klasyczne i powszechne procesy kulturowe człowieka. Uważa, że jednostka funkcjonuje zgodnie z normami tych systemów kulturowych, w których uczestniczy, zaś jej zachowanie względem innych i środowiska społecznego względem niej przebiega w sposób normatywnie uporządkowany ${ }^{6}$. W ujęciu społecznym adaptacja polega na zaprowadzeniu zjawiska harmonii pomiędzy potrzebami i dążeniami jednostki a wymogami i oczekiwaniami jej środowiska7. Aniela Popielarska ujmuje adaptację człowieka jako dostosowanie zachowania się do zmieniającego się otoczenia, poprzez równowagę wewnętrzną, rzetelne potraktowanie własnych problemów, właściwą samoocenę i umiejętne rozwiązywanie konfliktów bez częstego uruchamiania mechanizmów obronnych ${ }^{8}$.

Na zakończenie rozważań o adaptacji warto przytoczyć jej ujęcie w kontekście poczucia zadowolenia i szczęścia w realizacji podejmowanych ról społecznych. Traktuje ono, że przystosowanie społeczno-osobowe jednostki to taki sposób realizacji ról społecznych zgodnie z oczekiwaniami i wymaganiami otoczenia, który pozwala jednostce osiągnąć poczucie satysfakcji i zadowolenia9. We współczesnych interpretacjach za właściwy przebieg procesów adaptacyjnych człowieka odpowiedzialne są procesy biologiczno-fizjologiczne, cechy osobowości lub środowisko społeczne jednostki ${ }^{10}$.

Osobom wykluczonym społecznie często towarzyszy stres i wewnętrzne przekonanie, że nie poradzą sobie same z problemem. System radzenia ze stresem odgry-

${ }^{4}$ J. Piaget, Równoważenie struktur poznawczych, Wydawnictwo PWN, Warszawa 1981; J. Piaget, Psychologia dziecka, Wydawnictwo „Siedmiogród”, Wrocław 1993.

${ }^{5}$ A. Lewicki, O teorii biospołecznego przystosowania osobowości, „, Nowa Szkoła”, nr 5/1969, s. 269.

${ }^{6}$ F. Znaniecki, Ludzie teraźniejsi a cywilizacja przyszłości, Wydawnictwo PWN, Warszawa 1974.

${ }^{7}$ M. Kupisiewicz, Słownik pedagogiki specjalnej, Wydawnictwo naukowe PWN, Warszawa 2013, s. 11.

${ }^{8}$ A. Popielarska, Adaptacja, [w:] K. Bażkowa (red.), Encyklopedia zdrowia dziecka, Wydawnictwo Naukowe PWN, Warszawa 1978, s. 9.

9 D. Klus-Stańska, Adaptacja szkolna siedmiolatków, Wydawnictwo Uniwersytetu Warmińsko-Mazurskiego, Olsztyn 2004, s. 11.

${ }^{10}$ M. Kowalczyk-Jamnicka, Przestępcza adpatacja sprawców przestępstw przeciwko życiu i zdrowiu, Wydawnictwo Uniwersytetu Kazimierza Wielkiego, Bydgoszcz 2006, s. 11. 
wa istotną rolę w utrzymaniu zdrowia jednostki. W sytuacji stresowej uruchamiane są procesy adaptacyjne, które aktywizują posiadane przez jednostkę zasoby. Stevan E. Hobfoll w koncepcji COR (conservation of resources theory) przyjmuje, że adaptacja człowieka oraz jej jakość zależą od posiadanych zasobów zewnętrznych i wewnętrznych. Zasoby zewnętrzne znajdują się poza granicami Ja i nie są własnością jednostki. Zasoby wewnętrzne znajdują się w posiadaniu Ja lub pozostają w sferze Ja. W strukturalnej klasyfikacji zasobów Hobfoll dokonuje podziału zasobów ludzkich na ${ }^{11}$ :

a) zasoby materialne - są obiektami fizycznymi. Zaliczył do nich: dom, cenne sprzęty domowe czy środki komunikacji. Niektóre z nich odgrywają istotną rolę w procesie adaptacyjnym, inne kojarzone są ze statusem społecznym i samooceną jednostki;

b) zasoby osobiste - stanowią umiejętności oraz cechy osobowości i obejmują samoocenę, optymizm, skuteczność i nadzieję. W rozwoju tych cech istotne znaczenie odgrywają wczesne i długotrwałe doświadczenia rozwojowe, związane $\mathrm{z}$ relacjami pełnymi bezpieczeństwa i miłości, zwłaszcza w rodzinie, z rodzicami, którzy zachęcają do poznawania środowisk, a ostatecznie pozwalają na własną samodzielność i „odfrunięcie z gniazda”;

c) zasoby stanu - od nich uzależniony jest dostęp do innych zasobów. Obejmują one zdrowie, zatrudnienie, małżeństwo. Niektóre z nich są uwarunkowane biologicznie, inne trzeba wypracować, niektóre zaś można odziedziczyć razem z pozycją społeczną. Zasoby stanu zdobywane są powoli i często wymagają dużych inwestycji w tym zakresie. Można je szybko utracić;

d) zasoby energii - zaliczamy do nich pieniądze, wiarygodność kredytową i wiedzę. Są wymienne. Możemy je zamienić na zasoby należące do pierwszych trzech kategorii. Są zawsze cenniejsze przed wymianą ${ }^{12}$.

$\mathrm{W}$ strategiach skierowanych na prawidłową adaptację $\mathrm{w}$ środowisku jednostek niedostosowanych społecznie należy uwzględniać znaczenie zasobów adaptacyjnych jednostki, nawet jeśli są one niewielkie w porównaniu do zasobów osób funkcjonujących poprawnie.

\section{Wykluczenie społeczne - wielokontekstowość procesu}

Wykluczenie jest kategorią stosunkową współczesną. Termin ten spopularyzował na początku lat siedemdziesiątych Rémi Lenoir w pracy pt. Wykluczeni. Dotyczyła ona przede wszystkim nieprzystosowania społecznego, bowiem autor nie poruszył w niej innych problemów, które obecnie identyfikujemy z wykluczeniem, takich jak:

${ }^{11}$ S. E. Hobfoll, Stres, kultura i społeczność. Psychologia i filozofia stresu, Gdańskie Wydawnictwo Psychologiczne, Gdańsk 2006, s. 74 i następne.

12 Tamże, s. 75. 
bezrobocie, bieda czy segregacja miejska ${ }^{13}$. Użycie przez niego terminu „wykluczony” zapoczątkowało ogromną popularność tego określenia.

Od kilkunastu lat pojęcie wykluczenia społecznego zyskało na popularności nie tylko w debacie akademickiej, ale też publicznej, szczególnie w kontekście prowadzonej polityki społecznej. Do spopularyzowania problematyki wykluczenia społecznego przyczynił się znacznie o. Józef Wrzesiński, założyciel stowarzyszenia ATD „Czwarty Świat” („Pomoc wobec każdego nieszczęścia - Czwarty Świat”). Stowarzyszenie zostało założone we Francji w 1957 roku wraz z bezdomnymi z Noisy-le-Grand. W 1987 roku o. Wrzesiński przygotował raport dla francuskiej Rady Ekonomiczno-Społecznej, który był traktowany jako podstawowa informacja i refleksja na temat wykluczenia społecznego. Wskazał w nim, że kwestia wykluczenia społecznego powinna zostać uznana za priorytet narodowy, ponieważ proces ten - zdaniem kapłana - powoduje pogwałcenie wszelkich praw człowieka ${ }^{14}$.

W literaturze przedmiotu oraz w toczących się debatach dotyczących wykluczenia społecznego można dostrzec, że termin ten zazwyczaj jest używany w kontekście negatywnych kwestii społecznych. W sposobie definiowania wykluczenia społecznego najczęściej przyjmuje się kryterium uczestnictwa lub kryterium dostępu. W aspekcie analizowanego zagadnienia należy uwzględnić jeszcze kryterium ubóstwa, deprywacji czy problemy z prawem. Wszystkie one są istotne, ponieważ są jednoznacznie społecznie negatywne.

Wykluczenie społeczne jest utożsamiane $\mathrm{z}$ takimi konstruktami pojęciowymi, jak: marginalizacja, podklasa, ubóstwo czy pauperyzacja. Terminem tym określa się jednostki lub grupy społeczne, które nie są w stanie harmonijnie i w poczuciu zadowolenia uczestniczyć w życiu społecznym ani realizować podejmowanych ról społecznych zgodnie z wymaganiami otoczenia. Wykluczenie społeczne analizowane bywa w perspektywie całościowej, segmentowej lub biograficznej. Proces wykluczania społecznego w perspektywie biograficznej możemy traktować jako trajektorię zdarzenia doświadczonego przez jednostki lub grupy w czasie. Początkiem może być choroba, pogorszenie sytuacji materialnej itp. Zdarzenia te inicjują kolejne stadia procesu. Ewaluując znaczenie jednostki, przyczyniają się do dalszej degradacji życia codziennego i rozprzestrzeniają na kolejne obszary życia, powodując bezład, a nawet całkowitą utratę kontroli nad przebiegiem życia ${ }^{15}$.

W ustawie o zatrudnieniu socjalnym ${ }^{16}$ przyjęto, że wykluczenie jest sytuacją życiową, w której osoby doświadczające wykluczenia nie są w stanie same zaspokoić

13 R. Renoir, Les exsclus. Un Francais sur dix, Le Seuil, Paris 1974; podaję za: J. Damon, Wykluczenie, Oficyna Naukowa, Warszawa 2012, s. 12.

14 www.dziedzictwo.ekai.pl (dostęp 3.07.2017); za J. Damon, dz. cyt., s.13

15 G. Riemann, F. Schutze, Pojęcie trajektorii jako podstawowa koncepcja cierpienia bezładnych procesów społecznych, „Kultura i Społeczeństwo”, nr 2/1992, T. XXXVI, s. 89-109.

16 Ustawa z dnia 13 czerwca 2003 o zatrudnieniu socjalnym, Dz. U. 2003, poz. 1828, art. 1.1 (z późn. zm.) 
swoich podstawowych potrzeb, co może prowadzić do ograniczenia lub uniemożliwienia uczestnictwa w życiu rodzinnym, społecznym i zawodowym. W Narodowej Strategii Integracji Społecznej dla Polski ${ }^{17}$ przyjęto, że wykluczenie to brak lub ograniczenie możliwości uczestnictwa, wpływu i korzystania z podstawowych instytucji publicznych i rynków, które powinny być dostępne dla wszystkich.

Wykluczenie społeczne traktowane jest jako dynamiczny proces, który charakteryzuje się:

a) brakiem zasobów;

b) wielowymiarowością;

c) deficytami uczestnictwa (o różnym natężeniu) w życiu społecznym oraz w dostępie do rynku pracy, opieki medycznej, edukacji itp.;

d) prowadzeniem do sytuacji wielowymiarowej deprywacji o różnych stopniach natężenia;

e) możliwością zerwania więzi z rodziną i najbliższym środowiskiem;

f) możliwością utraty poczucia tożsamości i celu życia;

g) ograniczeniem lub dostępu do świadczeń socjalnych;

h) czynnikami utrwalającymi i błędnymi kołami, które sprawiają, że dominuje w cyklu życia i może być przekazywany międzypokoleniowo ${ }^{18}$.

Wśród wymiarów wykluczenia społecznego najczęściej wymieniane są:

a) produkcja, czyli zaangażowanie w działania produkcyjne; wykluczenia spowodowane bezrobociem lub niepełnosprawnością ograniczają lub uniemożliwiają to zaangażowanie;

b) konsumpcja, czyli zdolność nabywania dóbr; w wyniku doświadczanego ubóstwa następuje znaczne ograniczenie konsumpcji;

c) zaangażowanie polityczne; z powodu marginalizacji kulturowej i politycznej, następuje wyłączenie $z$ mechanizmów wpływu i władzy;

d) interakcje społeczne; w wyniku wykluczenia społecznego spada poziom integracji w sieciach rodzinnych, koleżeńskich i lokalnych, czego wynikiem jest doświadczanie samotności czy stany depresyjne ${ }^{19}$.

Toczące się debaty nad wykluczeniem społecznym wskazują na liczne skutki tego zjawiska. Według Ministerstwa Pracy i Polityki Społecznej zagraża ono porządkowi społecznemu, m.in. może prowadzić do radykalizacji postaw w środowiskach wykluczonych. W rodzinach może następować dziedziczenie negatywnych postaw i wzorców, pojawiają się patologie społeczne ${ }^{20}$. W Narodowej Strategii Integracji Społecznej

17 Narodowa Strategia Integracji Społecznej dla Polski, 2003, s. 23.

${ }_{18}$ R. Szarfenberg, Pojęcie wykluczenia społecznego, www.rszarf.ips.uw.edu.pl (dostęp: 28.06.2017).

${ }_{19}$ J. Grotowska-Leder, Ekskluzja społeczna-aspekty teoretyczne i metodologiczne, [w:] J. Grotowska-Leder, K. Faliszek (red.), Ekskluzja i inkluzja społeczna. Diagnoza, ukierunkowanie, kierunki działań, Wydawnictwo Edukacyjne „Akapit”, Toruń 2005, s. 28 i następne; J. Damon, dz.cyt, s. 35.

${ }^{20}$ Wykluczenie i integracja społeczna w Polsce. Ujęcie wskaźnikowe, Ministerstwo Pracy i Polityki Społecznej, Warszawa 2006, s. 88. 
zauważa się, że wykluczenie społeczne prowadzi do ograniczenia podmiotowości jednostek i grup, zanikania społecznej aktywności, zdolności do działania, co prowadzi z kolei do utrwalania bierności społecznej, a w konsekwencji do społecznej katastro$\mathrm{fy}^{21}$. W wymiarze jednostkowym skutkiem wykluczenia jest doświadczanie odrzucenia i poczucie bycia niepotrzebnym. Należy podkreślić, że najbardziej podatne na wykluczenie są jednostki, które z powodu braków kulturowych, dochodowych czy edukacyjnych nie potrafią się same obronić przed mechanizmami uruchamiającymi te procesy $^{22}$.

Skuteczne działania przeciwko wykluczeniu społecznemu to nie tylko polityka społeczna. Istotną rolę odgrywają zasoby, jakie jednostka zgromadziła w trakcie swojego życia. Trzeba zadać jednak pytanie, czy jest świadoma swoich potencjałów i czy potrafi je wykorzystać zgodnie z obowiązującymi normami i pełnionymi rolami w życiu codziennym.

\section{Założenia metodologiczne badań}

W kontekście powyższych rozważań w celu empirycznego określenia zasobów adaptacyjnych młodzieży ze środowisk marginalizowanych przeprowadzono badania w jednej ze świetlic środowiskowych w Bytomiu ${ }^{23}$. Na podstawie analizy dokumentacji placówki przyjęto założenie, że jej podopieczni są zagrożeni wykluczeniem społecznym w swoim mieście. Oferowana w świetlicy pomoc skoncentrowana jest na zaspokajaniu podstawowych potrzeb. Jednym z celów jej działania jest zapobieganie tworzeniu pokoleniowej patologii. Prezentowane w artykule badania obejmują wybrane zasoby adaptacyjne młodzieży uczęszczającej na zajęcia. Klasyfikację zasobów przyjęto wg S. E. Hobfola, z podziałem na zasoby osobiste, energii, stanu i wewnętrzne ${ }^{24}$.

Podstawowym celem niniejszej pracy było przedstawienie zasobów adaptacyjnych młodzieży uczęszczającej do świetlic środowiskowych. Postawiono następujące pytania badawcze:

1. Jakie zasoby osobiste posiadają podopieczni świetlic środowiskowych?

2. Jakie zasoby energii i stanu posiada młodzież uczęszczająca do świetlicy środowiskowej w Bytomiu?

3. Jakie zasoby zewnętrzne posiadają wychowankowie badanej placówki?

${ }^{21}$ Narodowa Strategia Integracji Społecznej dla Polski, 2003, s. 23.

${ }^{22}$ S. Kawula, Pedagogika społeczna wobec zjawiska marginalizacji i normalizacji, [w:] S. Kawula, B. Białobrzeska (red.), Człowiek w obliczu wykluczenia i marginalizacji społecznej. Wokół zagadnień teoretycznych, Wydawnictwo Edukacyjne „Akapit”, Toruń 2006, s. 55.

${ }^{23}$ Koncepcja referowanych badań powstała w ramach seminarium magisterskiego.

${ }^{24}$ S. E. Hobfoll, dz. cyt. 
Badania przeprowadzono w maju 2016 roku metodą sondażową, dodatkowo przeanalizowano dokumentację wychowanków. Poddana badaniom grupa liczyła 50 osób w wieku od 12 do 17 lat.

\section{Wyniki badań własnych}

Przystępując do diagnozy zasobów osobistych, przyjęto następujące wskaźniki tych zasobów: własna samoocena, motywacja, umiejętność współdziałania w grupie, nastawienie do życia, optymizm, poczucie własnej skuteczności. Nikt z badanych nie określił swojej samooceny jako wysokiej. Zdecydowana większość (42 osoby) stwierdziła, że nie posiada żadnych uzdolnień, niczym się nie wyróżnia oraz nie zna swoich możliwości, nikt ich nie docenia, są nielubiani. 38 badanych wypowiedziało się, że nie przewidują zmian w swoim życiu, bo tak im dobrze i nie mają też możliwości zmiany swojego życia.

Dane zawarte $\mathrm{w}$ dokumentacji to potwierdzają. W rodzinach badanych wychowanków istnieje problem uzależnienia i bezrobocia. W dokumentacji sporządzonej na potrzeby diagnozy i sądu, dotyczącej współpracy świetlicy ze szkołami, do których uczęszczają podopieczni, zawarto informacje, że uczniowie ci nie angażują się w działalność na terenie szkoły, często wywołują konflikty, w których podkreślają swoją siłę fizyczną (chłopcy) i atrakcyjność zewnętrzną (dziewczęta). Wśród badanych wskaźników skupiających się na posiadanych zasobach osobistych, tylko umiejętność współdziałania w grupie uzyskała wynik wysoki (48 badanych wychowanków stwierdziło, że potrafią współpracować w grupie).

Badane zasoby energii to: chęć kształcenia się wychowanków, ich ambicje, pracowitość, umiejętność radzenia sobie w sytuacjach trudnych, dążenia i cele. Każde dziecko wyraziło chęć ukończenia jak najszybciej szkoły zawodowej i podjęcia pracy. Umiejętnością radzenia sobie w sytuacjach trudnych wykazali się wszyscy badani. Zarówno dziewczęta, jak i chłopcy uważają, że poradzą sobie w każdej sytuacji, ponieważ od dziecka już to robią. Wśród wypowiedzi warto odnotować: jak ojciec trzepał matkę, to $w$ wieku 4 lat uciekałem do sąsiadki; nigdy nie proszę rodziców o jedzenie, sama sobie radzę; ludzie sa naiwni i ja to wykorzystuję. Protokoły rozmów wychowawców z rodzicami potwierdzają wyniki badań sondażowych i wskazują, że ukończenie przez dzieci szkoły średniej nie należy do priorytetów tych rodzin. Uważają, że dzieci muszą sobie same radzić, bo rodzina jest w bardzo trudnej sytuacji.

Przystępując do diagnozy zasobów stanu, badana grupa określała je na podstawie następujących wskaźników: rodzina, sytuacja szkolna i wykształcenie, posiadane autorytety, doświadczane problemy, wsparcie, postawa wobec innych osób. Literatura przedmiotu dostarcza informacji o badanych wskaźnikach ${ }^{25}$. Dokumentacja wy-

${ }^{25}$ B. M. Nowak, Rodzina w kryzysie. Studium resocjalizacyjne, PWN, Warszawa, 2011; Skazani na wykluczenie M. Kalinowski, I. Niewiadomska (red.), Wydawnictwo KUL, Lublin 2010. 
chowanków dowodzi, że ich rodziny są dysfunkcyjne, ubogie, korzystające z różnorodnych form pomocy społecznej (między innymi umieszczenie w świetlicy). Dzieci doświadczają wielu problemów (od braku podstawowych posiłków, stosownej do pory roku odzieży, po stosowaną wobec nich agresję i przemoc). W szkole mają liczne problemy, nie są lubiani. Średnia ocen za ostatni semestr oscyluje od 2,8 do 3,2. Odpowiedzi podopiecznych w badaniach ankietowych dotyczące tego zagadnienia wskazują, że zdecydowana większość (42), nie może liczyć na wsparcie swoich rodziców, 6 wskazało jako autorytet babcię, pozostali nie wskazali żadnego autorytetu. Z doświadczanych problemów 36 osób wymieniło ubóstwo, brak środków do życia, alkoholizm rodzica, brak modnych ubrań, źle wyposażone mieszkania oraz brak ogrzewania w domu. Pozostali (14) wymieniali agresję koleżanek, brak pieniędzy na wyjazdy ze szkołą, opiekę nad młodszym rodzeństwem pod nieobecność rodzica. Wszyscy stwierdzili, że są nielubiani w swoim otoczeniu oraz w szkole i dlatego nikomu nie ufają. Wielu (24) doświadczyło tzw. zdrady, tj. upublicznienia tajemnicy.

Do analizy wyników badań dotyczących zasobów zewnętrznych wybrano: wsparcie społeczne $\mathrm{w}$ najbliższym otoczeniu, prawidłowe wzorce zachowań, poczucie bezpieczeństwa, dobre relacje z rodziną i status ekonomiczny. Na podstawie dokumentacji można stwierdzić, że dzieci muszą radzić sobie same. Tylko w przypadku dwóch osób spośród badanych istnieje stały kontakt z dziadkami. Rodzice otrzymują pomoc społeczną w postaci zasiłków pieniężnych. W ramach wspierania rodzin na wniosek pracowników socjalnych dzieci umieszczono w świetlicy. Do pięciu rodzin co trzy miesiące dostarczana jest paczka żywnościowa. Tylko w jednym przypadku rodzina utrzymuje dobre stosunki sąsiedzkie. W kwestionariuszu 46 respondentów wskazało, że ich rodzice nie utrzymują bliskich relacji z sąsiadami, w 34 przypadkach podopieczni świetlicy nie utrzymują bliskich relacji z rówieśnikami ze swoich kamienic. Wszyscy stwierdzili, że status ekonomiczny ich rodzin jest niski z powodu bezrobocia. 43 badanych określiło swoje relacje z rodziną jako dobre, jednocześnie podkreślając, że najlepiej i najbezpieczniej czują się ze swoimi koleżankami i kolegami ze świetlicy. Jak niektórzy napisali, nikt mi głowy nie zawraca, nic nie muszę robić, mogę mieć własne zdanie.

\section{Podsumowanie}

Każdy człowiek w trakcie swojego życia narażony jest na szereg traumatycznych doświadczeń, wypadków losowych i różnych nieszczęść. Badania dowodzą, że spotykane są jednostki, które mimo tragicznych sytuacji w życiu, adaptują się pozytywnie do rzeczywistości społecznej, w której zamieszkują ${ }^{26}$. Podopieczni świetlic środowi-

${ }^{26}$ Za: J. Jarczyńska, Wspomaganie procesu budowania prężności u dzieci i młodzieży zagrożonej rozwojem zespołu zachowań problemowych poprzez wzmacnianie relacji z rodzicami, [w:] W. Junik (red.), Resilience, Warszawa 2011; A. Borucka, K. Ostaszewski, Koncepcja resilience. Kluczowe poje- 
skowych są narażeni na szereg czynników ryzyka. W ich adaptacji społecznej korzystne byłoby zdiagnozowanie tzw. płaszczyzny oporu, którą może być rodzina, posiadane zdolności, dobra umiejętność komunikowania się, dobre relacje rówieśnicze ${ }^{27}$. Według Sandry Prince-Embusy, zdolność pozytywnej adaptacji pomimo doświadczanego ryzyka zależy od cech osobowościowych jednostki (np. zdolności, temperamentu), środowiska rodzinnego (pozytywnego wzoru rodziny, otrzymywanego wsparcia emocjonalnego, prawidłowej struktury i silnej więzi z rodzicami) i środowiska pozarodzinnego (pozytywnych osiągnięć szkolnych, dobrych relacji z rówieśnikami oraz $\mathrm{z}$ dorosłymi $)^{28}$.

W kontekście zaprezentowanych badań zauważamy, że badani podopieczni świetlicy socjoterapeutycznej narażeni są na współwystępowanie wielu czynników ryzyka, tkwiących w środowisku rodzinnym, szkolnym i rówieśniczym. Przeprowadzona analiza ich zasobów adaptacyjnych pozwala je określić w odniesieniu do badanej grupy:

1. Zasoby osobiste - spośród badanych zasobów tylko umiejętność współdziałania w grupie może stanowić płaszczyznę oporu wobec napotykanych czynników ryzyka. Szczególnie niesprzyjającym faktem w kontekście pozytywnej adaptacji może być niskie poczucie własnej wartości.

2. Zasoby energii i stanu - dominującym zasobem energii była umiejętność radzenia sobie w sytuacjach trudnych. Dążenia i cele związane są z jak najszybszym zakończeniem edukacji szkolnej (ukończenie szkoły zawodowej) i podjęciem pracy. Badani wychowankowie nie cieszą się dobrą opinią w szkole, nie doceniają nauki szkolnej, często wagarują. Zastanawiający jest fakt, że badane zasoby stanu stanowią raczej czynniki ryzyka niż zasoby wspierające pozytywną adaptację. Wychowankowie są nieufni wobec innych osób, mają problemy komunikacyjne, uczą się bardzo słabo i nie otrzymują dostatecznego wsparcia rodzinnego ani rówieśniczego.

3. Zasoby zewnętrzne - w badanej grupie nie stanowią zasobów adaptacyjnych. Luźne relacje w środowisku pozarodzinnym i rówieśniczym nie dają wsparcia $\mathrm{w}$ radzeniu sobie z kolejnymi trudnościami. Istniejące dysfunkcje w rodzinach nie stanowią prawidłowych wzorców zachowań i nie sprzyjają dobrym relacjom. Najbezpieczniej badani czują się w świetlicy. Możemy przyjąć, że wśród zasobów zewnętrznych wspierających wychowanków jest grupa rówieśnicza ze świetlicy socjoterapeutycznej.

$\mathrm{W}$ artykule tym podjęto się zbadania i przedstawienia wybranych zasobów adaptacyjnych wychowanków świetlic socjoterapeutycznych. Zarówno grupa badawcza, jak i badane zasoby stanowią niewielki wycinek rzeczywistości społecznej, jaką two-

cia i wybrane zagadnienia, 2008, http://www.ncbi.nlm.nih.gov/pmc/articles/PMC2777715/ (dostęp: 9.06.2017).

${ }^{27}$ I. Mudrecka, Wykorzystanie koncepcji resilience w profilaktyce niedostosowania społecznego i resocjalizacji, „Resocjalizacja Polska”, nr 5/2013, s. 51.

${ }^{28}$ Za: tamże. 
rzą podopieczni świetlic środowiskowych. Bytom jest miastem w którym ubóstwo, bezrobocie i marginalizację społeczną można spotkać na każdym osiedlu. Z tytułu licznych przesiedleń (z powodu szkód górniczych) relacje sąsiedzkie i rówieśnicze są powierzchowne.

Można stwierdzić, że w badana grupa wychowanków świetlicy socjoterapeutycznej w Bytomiu-Łagiewnikach posiada bardzo nieliczne zasoby adaptacyjne. W tym przypadku profilaktyka pokoleniowej patologii będzie niezwykle utrudniona.

\section{Bibliografia}

Borucka A., Ostaszewski K., Koncepcja resilience. Kluczowe pojęcia i wybrane zagadnienia, 2008, http://www.ncbi.nlm.nih.gov/pmc/articles/PMC2777715/ (dostęp: 9.06.2017).

Damon J., Wykluczenie, Oficyna Naukowa, Warszawa 2012.

Doroszewska J., Pedagogika specjalna, Wydawnictwo Ossolineum, Wrocław 1995.

Grotowska-Leder J., Ekskluzja społeczna - aspekty teoretyczne i metodologiczne, [w:] J. Grotowska-Leder, K. Faliszek (red.), Ekskluzja i inkluzja społeczna. Diagnoza, ukierunkowanie, kierunki działań, Wydawnictwo Edukacyjne „Akapit”, Toruń 2005, s. 28 i n.

Hobfoll S. E., Stres, kultura i społeczność. Psychologia i filozofia stresu, Gdańskie Wydawnictwo Psychologiczne, Gdańsk 2006.

Jarczyńska J., Wspomaganie procesu budowania prężności u dzieci i młodzieży zagrożonej rozwojem zespołu zachowań problemowych poprzez wzmacnianie relacji z rodzicami, [w:] W. Junik (red.), Resilience, Warszawa 2011, s. 147-162.

Klus-Stańska D., Adaptacja szkolna siedmiolatków, Wydawnictwo Uniwersytetu Warmińsko-Mazurskiego, Olsztyn 2004.

Kowalczyk-Jamnicka M., Przestępcza adaptacja sprawców przestępstw przeciwko życiu i zdrowiu, Wydawnictwo Uniwersytetu Kazimierza Wielkiego, Bydgoszcz 2006.

Kopaliński Wł., Słownik wyrazów obcych i zwrotów obcojęzycznych $z$ almanachem, Oficyna Wydawnicza Rytm, Warszawa 2006.

Kupisiewicz M., Słownik pedagogiki specjalnej, Wydawnictwo naukowe PWN, Warszawa 2013.

Lewicki A., O teorii biospołecznego przystosowania osobowości, „Nowa Szkoła”, nr 5/1969.

Mudrecka I., Wykorzystanie koncepcji resilience $w$ profilaktyce niedostosowania społecznego i resocjalizacji, „Resocjalizacja Polska”, nr 5/2013, s. 51.

Narodowa Strategia Integracji Społecznej dla Polski, 2003.

Nowak B. M., Rodzina w kryzysie. Studium resocjalizacyjne, PWN, Warszawa 2011.

Ojciec Józef Wrzesiński, www.dziedzictwo.ekai.pl (dostęp: 3.07.2017).

Piaget J., Równoważenie struktur poznawczych, Wydawnictwo PWN, Warszawa 1981. 
Piaget J., Psychologia dziecka, Wydawnictwo „Siedmiogród”, Wrocław 1993.

Popielarska A., Adaptacja, [w:] K. Bażkowa (red.), Encyklopedia zdrowia dziecka, Wydawnictwo Naukowe PWN, Warszawa 1978, s. 9.

Riemann G., Schutze F., Pojęcie trajektorii jako podstawowa koncepcja cierpienia bezładnych procesów społecznych, „Kultura i Społeczeństwo”, nr 2/1992, T. XXXVI, s. 89-109.

Sęk H., Wsparcie społeczne jako kategoria zasobów $i$ wieloznaczne funkcje wsparcia, [w:] Z. Juczyński, N. Ogińska-Bulik (red.), Zasoby osobiste i społeczne sprzyjające zdrowiu jednostki, Wydawnictwo Uniwersytetu Łódzkiego, Łódź 2003, s. 17-32.

Skazani na wykluczenie, M. Kalinowski, I. Niewiadomska (red.), Wydawnictwo KUL, Lublin 2010.

Szarfenberg R., Pojęcie wykluczenia społecznego, www.rszarf.ips.uw.edu.pl (dostęp: 28.06.2017).

Ustawa z dnia 13 czerwca 2003 o zatrudnieniu socjalnym, Dz. U. 2003, poz. 1828, art. 1.1 (z późn. zmn.)

Wykluczenie i integracja społeczna w Polsce. Ujęcie wskaźnikowe, Ministerstwo Pracy i Polityki Społecznej, Warszawa 2006.

Znaniecki F., Ludzie teraźniejsi a cywilizacja przyszłości, Wydawnictwo PWN, Warszawa 1974.

\title{
Adaptation resources of the adolescents at risk of social exclusion
}

Abstract: The aim of the article is to present the adaptation resources of youth people at risk of social exclusion. The focus was on the classification of S. Hobble's resources. 50 people in the community day care center in Bytom were examined. The results of the research indicated that the research group has very few resources for positive adaptation.

Keywords: Adaptation resources, social exclusion, social adaptation

\begin{abstract}
About the authors: Dr hab. Irena Motow, prof. AHE - Associate Professor at the Humanities and Economics Academy in Lodz. Head of the Department of Pedagogy of Resocialization and Social Prevention. Pedagogue with 25 years of work experience with juvenile delinquency, conducting research on socially unsuitable integration, after leaving social rehabilitation institutions.

Dr Marta Motow-Czyż - assistant Professor at the Department of Biological and Medical Sciences at the Institute of Physical Education of Tourism and Physiotherapy, Jan Długosz University in Czestochowa. Physiotherapist with 14 years of experience in rehabilitation of children and adolescents in terms of posture defects. Researcher performing research on body posture defects and effectiveness of rehabilitation methods in the treatment of locomotive organs diseases.
\end{abstract}




\title{
Aleksandra Sobczyk-Kubiak*
}

Uniwersytet Łódzki

olajurek@o2.pl

\section{Rozwój osobisty osób starszych jako jeden z obszarów wykluczenia społecznego}

\begin{abstract}
Streszczenie: Starość jest takim okresem w życiu człowieka, w którym zachodzi wiele zmian fizjologicznych, psychologicznych i społecznych. Przed jednostką stają zadania typowe dla tego okresu rozwojowego: przejście na emeryturę, adaptacja do starości, mądrość transcendentna czy wreszcie przygotowanie do odejścia. Jednostki starzejące się dotykają także zjawiska społeczne takie jak ageism czy gerontofobia. Sposób starzenia nie zmienił się od lat, zmieniły się jednak warunki w którym przyszło się starzeć. Współczesna cywilizacja młodości i technologii stawia przed osobami starszymi wiele nowych wyzwań, między innymi konieczność nauczenia się obsługiwania nowoczesnych urządzeń, funkcjonowania w rzeczywistości cyfrowej. To dla osób starszych czas intensywnej nauki, a jej nie podjęcie grozi cyfrowym wykluczeniem. Obszar rozwoju osobistego to kolejny z obszarów, w którym osoby starsze dotyczy wykluczenie i marginalizacja. Prezentowana na rynku oferta nie uwzględnia specyfiki potrzeb starszych ludzi a sposoby rozpowszechniania nie ułatwiają osobom starszym dostępu do niej.

Słowa kluczowe: ageism, rozwój osobisty, starość
\end{abstract}

\section{Wstęp}

Starzenie się jest naturalnym procesem rozwojowym, w trakcie którego zachodzi w jednostce wiele bardzo skomplikowanych zmian, na płaszczyznach: psychologicznej, osobowościowej, biologicznej oraz społecznej. Pod niemal każdym względem zmienia się sposób funkcjonowania człowieka, zmianom ulega wygląd, stan zdrowia, role społeczne i rodzinne, niektóre z potrzeb, a także tożsamość oraz postrzeganie sie-

* Mgr Aleksandra Sobczyk-Kubiak - psycholog, socjolog i pedagog, life-coach i trener rozwoju osobistego. Od 2016 roku doktorantka w Instytucie Socjologii na Wydziale Ekonomiczno-Socjologicznym Uniwersytetu Łódzkiego. Interesuje się wpływem, jaki wywierają na siebie jednostka i kultura, uzależnieniami behawioralnymi, psychologią pozytywną, rozwojem osobistym i wzrastaniem. Preferuje narracyjne metody pracy z człowiekiem. Specjalista Racjonalnej Terapii Zachowania. 
bie i świata. Proces starzenia ma przygotować jednostkę do nowych zadań życiowych, do sprostania rzeczywistości w obliczu wyzwań schyłku życia ${ }^{1}$. Elementy związane z biologicznym i psychologicznym starzeniem się organizmu pozostają niezmienne od stuleci, jednak rzeczywistość społeczna ulega gwałtownym i szybkim przemianom, stając się dla ludzi starszych zupełnie inną, niż była 50 lat temu. Rozwój technologii sprawił, że zmieniły się warunki życia codziennego, system opieki medycznej i socjalnej, a co za tym idzie - jakość życia i funkcjonowania osób niepełnosprawnych czy przewlekle chorych ${ }^{2}$. Wynalazki z zakresu medycyny pozwalają na dokładną i precyzyjną diagnostykę, co sprawia że współczesny senior może być bardziej aktywny i w sposób bardziej efektywny zapobiegać chorobom wieku podeszłego lub je leczyć. Technologia przestała być luksusem, jest nieodłącznym elementem codzienności (także dla ludzi starszych). Sprawia, że życie staje się łatwiejsze, ale jednocześnie stawia przed osobami starszymi wiele nowych wyzwań i zadań. Wraz z postępem i rozwojem technologicznym zaobserwować można promowanie wartości takich jak edukacja, rozwój, kreatywność. W odpowiedzi na takie zapotrzebowanie wykształcił się prężnie działający, różnorodny i realizowany wieloma kanałami (m.in. cyfrowo) rynek usług związanych z rozwojem osobistym. Jednak zamiast stać się narzędziem ułatwiającym właściwą adaptację seniorom do trudnej i wymagającej rzeczywistości XXI wieku, stał się kolejnym obszarem wykluczenia osób starszych, słabo dostępnym i niedopasowanym do ich możliwości. Usługi nowoczesnego wspierania rozwoju, takie jak kursy mindfullness, coaching, treningi relaksacyjne, szkolenia, warsztaty i wykłady „należą” do świata ludzi młodych.

\section{Procesy związane z biologicznym i psychicznym starzeniem się}

W każdym organizmie, również ludzkim, zachodzą naturalne zmiany związane z cyklem życia komórki, czyli jej wzrostem, dojrzewaniem, przekwitaniem i obumieraniem. Starość jest tym okresem rozwojowym, w którym organizm przystosowuje się do przekwitania i śmierci. Zmiany fizjologiczne mają więc na celu powolne wyciszanie, zwalnianie funkcji życiowych aż do ich całkowitego ustania, czyli śmierci organizmu³ . Wśród najczęściej wymienianych zmian, jakie zachodzą w jednostce wymienia się zwolnienie ogólnego poziomu metabolizmu oraz przewagę procesów katabolicznych nad anabolicznymi ${ }^{4}$. Osłabieniu ulega układ kostno-szkieletowy, który w wyniku zmniejszenia gęstości kośćca oraz jego odwapnienia staje się bardziej podatny na

${ }^{1}$ M. Straś-Romanowska, Późna dorosłość. Wiek starzenia się, [w:] J. Trempała (red.), Psychologia rozwoju człowieka, Warszawa 2004, str. 263-292.

2 P. Nosal, Technologia i sport, Poznań 2014.

3 D. Bromley, Psychologia starzenia się, Warszawa 1969.

${ }^{4}$ Z. Szarota, Gerontologia społeczna i oświatowa. Zarys problematyki, Kraków 2004. 
urazy oraz deformacje. Zmienia się postawa ciała ( $\mathrm{z}$ wyprostowanej na przygarbioną), maź stawowa wysycha, powodując ograniczenia w ruchu, słabnie siła i wydolność mięśni, a z powodu ubytków białka zmienia się struktura skóry (zmarszczki i bruzdy). Gorsze funkcjonowanie układy hormonalnego objawia się min. przebarwieniami na skórze, spada wydolność układu pokarmowego i wydalniczego ${ }^{5}$. Zmiany nie omijają narządów zmysłów, które z powodu przytępienia zaczynają sprawiać kłopoty. Pogarsza się zmysł węchu, słuchu, wzroku, smaku, gorzej działa również błędnik, ograniczając zmysł równowagi. Zmienia się głos, stopniowo spada wydolność tlenowa organizmu. Serce zaczyna pracować wolniej, organizm jest zatem słabiej natleniony i odżywiony. Komórki tętnic tracą swoją elastyczność, krew gęstnieje a płytki miażdżycowe mogą ograniczać światło naczyń. Wszystkie te zmiany stanowią podwyższone ryzyko chorób takich jak udary czy inne choroby krążenia ${ }^{6}$.

Zmiany we wszystkich układach i narządach ciała skutkują u osób starszych większą męczliwością, spadkiem energii życiowej i wigoru, mniejszą gotowością do podejmowania wysiłku. Tkanki ulegają stopniowej degeneracji, co przekłada się na możliwości funkcjonowania, odporność oraz wygląd osób starszych ${ }^{7}$. Wszystkie zmiany fizyczne mają na celu powolne wycofanie się funkcji życiowych i przygotowanie organizmu do najważniejszej zmiany w cyklu życia, jaką jest śmierć. Skutkują naturalną tendencją do wycofywania się z niektórych życiowych aktywności, skłaniania się „ku wewnątrz". Potrzeba aktywności i uczestniczenia w życiu rodzinnym i społecznym zaczyna równolegle istnieć w życiu osoby starszej z potrzebą wycofywania się, szukania odosobnienia, większej refleksyjności.

Starzeje się układ nerwowy, sieć neuronów ulega zmniejszeniu, czas reakcji seniorów wydłuża się, obniżeniu ulegają niektóre funkcje psychiczne, na przykład zapamiętywanie, zdolność do działań twórczych, spowolnieniu ulega zdolność uczenia się? Niektóre procesy psychiczne ulegają wzmocnieniu, osoby starsze są bardziej rozsądne i dokładniej analizują problem, zwiększa się udział myślenia relatywistycznego, co ułatwia sprawniejsza selekcję danych i podejmowanie wyborów spójnych wewnętrznie $^{9}$. Pojawia się również zdolność słabo dostępna dla pozostałych okresów rozwojowych - do transcendencji i osiągnięcia mądrości; rozwija się intuicja oraz potrzeba duchowości, osiągnięcia harmonii. Struktury psychiczne integrują się na wszystkich poziomach, co może doprowadzić do stanu poszerzenia świadomości ${ }^{10}$ oraz gerotranscendencji ${ }^{11}$. Naturalnym zadaniem rozwojowym $\mathrm{w}$ tym okresie życia jest, według

${ }^{5}$ D. Bromley, dz. cyt.

6 Tamże.

M. Straś-Romanowska, dz. cyt.

8 A. Brzezińska, Psychologiczne portrety człowieka, Gdańsk 2005.

9 A. Scharlach, B. Robinson, Curriculum Module on the Aging Process University of California, http://garnet.berkleley.edu/ageing/ModuleProcess.html (dostęp: 3.03.2015).

${ }^{10}$ M. Straś-Romanowska, dz. cyt.

${ }^{11}$ S. Steuden, Psychologia starzenia się i starości, Warszawa 2011. 
klasyfikacji zadań cyklu życia Eriksona, zbudowanie integralności ego vs rozpacz ${ }^{12}$. Potrzeba podsumowania i zbilansowania życia może prowadzić do głębokiej refleksji na temat sensu istnienia, oraz szczególnego rodzaju mądrości. Osiągnięcie mądrości transcendentnej jest możliwe jednak tylko wtedy, gdy jednostka ma świadomość procesów, jakie zachodzą w jej ciele i umyśle, akceptuje swoje życie i jest pogodzona ze sobą, tym co nieuniknione, przebiegiem swojego życia i swoim indywidualnym $\operatorname{losem}^{13}$. Osoby, które doświadczają własnej starości jako nieszczęścia i przeżywają ją jako krzywdę i zjawisko negatywne, nie maja szansy na to, aby uzyskać taką mądrość. Są negatywnie nastawione do samych siebie i własnej starości, a świat postrzegają jako wrogi i krzywdzący ${ }^{14}$. Najważniejsze zadania dotyczące sfery biopsychicznej, jakie stoją przed ludźmi w tym okresie życia, to: pogodzenie się ze stratami na polu zdrowia, wytrzymałości, ograniczeń własnej cielesności - zaakceptowanie starości oraz pogodzenie się z nadchodzącym odejściem swoim i bliskich (rodzeństwa, partnera, przyjaciół $)^{15}$.

Tak liczne i wieloaspektowe zmiany wymagają uruchomienia procesów adaptacyjnych przez jednostkę. Naukowcy nie pozostawiają wątpliwości, że dla procesu pomyślnego starzenia się istotne jest odczuwanie subiektywnego poczucia dobrostanu, sensu życia ${ }^{16}$ oraz podejmowanie aktywności, rozumianej w tym okresie jako czynny udział w życiu rodzinnym, intelektualnym, społecznym i kulturalnym ${ }^{17}$. Wielu seniorów rezygnuje jednak z podejmowania aktywności, ulegając pesymistycznej postawie, negatywnym stereotypom lub w wyniku zniechęcenia własną kondycją ${ }^{18}$. Należy podkreślić, że właściwe i konstruktywne przystosowanie do starości niesie możliwości rozwoju i podejmowania aktywności adekwatnej do sprawności, czerpania satysfakcji z życia oraz z relacji rodzinnych i towarzyskich. Przystosowanie destruktywne wzmacnia natomiast negatywne zmiany w osobowości, może powodować depresję, poczucie rozżalenia i skrzywdzenia, negatywne relacje z samym sobą i otaczającą rzeczywistością oraz wyolbrzymianie uciążliwości przy jednoczesnym braku korzystania z możliwości, jakie realnie istnieją. Takie negatywne zaadaptowanie do starości uniemożliwia rozwój osobisty, uzyskanie mądrości transcendentnej i wglądu w swoje życie, a także rozwój duchowy. Powoduje jednocześnie głębokie poczucie bycia nie-

${ }^{12}$ Por. Straś-Romanowska, dz. cyt.

13 Tamże.

${ }^{14}$ I. Hamilton, Psychologia starzenia się. Wprowadzenie, Poznań 2006.

15 Tamże.

${ }^{16}$ M. Mamak-Zdanecka, „Pomyślne starzenie się” w wymiarze demograficznym, społecznym, gerontologicznym, [w:] M. Synowiec-Piłat, B. Kwiatkowska, K. Borysławski (red.), Inkluzja czy ekskluzja? Człowiek stary w społeczeństwie, Wrocław 2015, s. 19-36.

${ }_{17}$ E. Miszczak, Aktywność seniorów sposobem przeciwdziałania negatywnym skutkom procesu starzenia się, [w:] D. Kałużna, P. Szukalski (red.), Jakość życia seniorów XXI wieku. Ku aktywności, Łódź 2010, s. 24-33.

${ }_{18}$ P. Szukalski Stan zdrowia Polek i Polaków na przedpolu starości, [w:] P. Szukalski (red.), To idzie starość. Postawy osób w wieku przedemerytalnym. Raport z badań, Warszawa 2008, s. 7-29. 
szczęśliwym i nie pozwala pogodzić się z nadchodzącym kresem życia, niosąc psychiczny ból i lęk przed tym, co nieuniknione ${ }^{19}$.

\section{Rzeczywistość społeczna osób starszych}

Kolejną płaszczyzną głębokich przemian, jakie dotykają seniorów jest ich sytuacja społeczna. Przejście na emeryturę wiąże się z utratą części zasobów finansowych oraz prestiżu. Sytuacja ekonomiczna pogarsza się, a seniorzy muszą się pogodzić z tym, że nie grają już przewodniej roli ani w pracy, ani w rodzinie ${ }^{20}$. Podejmowane są za to nowe role życiowe, np. dziadków, emerytów. Należy poradzić sobie z poczuciem straty, przebudować swoją aktywność, znaleźć źródło satysfakcji i samospełnienia inne niż praca zawodowa, przewartościować swoją samoocenę ${ }^{21}$. Rzeczywistość społeczna konfrontuje seniorów z wykluczaniem w różnych jej obszarach. Wykluczenie z życia zawodowego oraz $\mathrm{z}$ niektórych form aktywności z powodu gorszej formy wydają się procesami naturalnymi i oczywistymi. Jednak kultura młodości, w której przyszło funkcjonować współczesnym seniorom, posuwa się o wiele dalej. Osoby starsze muszą się zmierzyć z licznymi negatywnymi stereotypami na swój temat. Ponieważ promowane są młodość i piękno, seniorzy przestają być widoczni w przestrzeni publicznej ${ }^{22}$, a jeśli są do niej zapraszani, to głównie po to, aby proponować im liczne zabiegi odmładzające ${ }^{23}$. Starość jako zjawisko jest pomijana, ośmieszana, bądź traktowana jako przykra przypadłość, na którą należy coś zaradzić. Brakuje atrakcyjnych propozycji dla tego obszaru wiekowego ${ }^{24}$. Starsi ludzie spotykają się więc z ageizmem, czyli dyskryminacją (wykluczeniem) ze względu na wiek, a nawet $\mathrm{z}$ gerontofobią (lęk przed osobami starszymi $)^{25}$. Definicja wykluczenia społecznego, jaką podaje Encyklopedia Zarządzania, brzmi:

Wykluczenie społeczne to sytuacja, w której dana jednostka będąca członkiem społeczeństwa nie może normalnie uczestniczyć w działaniach obywateli tego społeczeństwa, przy czym ograniczenie to nie wynika z jej wewnętrznych przekonań, ale znajduje się poza kontrolą wykluczonej jednostki. Wykluczenie społeczne jest zjawiskiem wielowymiarowym i w praktyce oznacza niemożność uczestnictwa w życiu gospodarczym, politycznym jak i kulturowym, w wyniku

\footnotetext{
${ }^{19}$ S. Steuden, dz. cyt.

${ }^{20}$ Z. Szarota, dz. cyt.

${ }^{21}$ M. Straś-Romanowska, dz. cyt.

22 E. Sygit, Dlaczego dyskryminujemy osoby starsze, „Psychogeriatria Polska”, nr 5(4)/2008, s. $153-158$.

${ }^{23}$ I. Zakowicz, Starzenie się w kulturze młodości. Wybrane strategie obrazowania starości $w$ reklamie. „Ogrody Nauk i Sztuk”, nr 2/2012, s. 381-398.

${ }^{24}$ E. Zierkiewicz, I Kowalczyk, Konsumentka czy konsumowana, „Kultura Popularna”, nr 2/2002, s. $119-124$.

${ }_{25}$ T. Nelson, Ageism and discrimination, [w:] J. Birren (red.), Encyclopedia of Gerontology, San Diego 2007.
} 
braku dostępu do zasobów, dóbr i instytucji, ograniczenia praw społecznych oraz deprywacji potrzeb ${ }^{26}$.

Oznacza to, że obiekty czy wydarzenia łatwo dostępne dla młodych nie są tak samo dostępne dla starszych lub są niedostosowane do ich potrzeb czy zainteresowań. Dodatkowym czynnikiem wpływającym na wykluczenie społeczne starszych jest ograniczenie ich dochodów, a co za tym idzie - pogorszenie sytuacji materialnej. Doskonałą ilustracją zjawiska wykluczenia jest sytuacja na rynku pracy osób 45+, które mimo możliwości i kompetencji nie są w stanie uczestniczyć w rynku pracy zgodnie ze swoimi predyspozycjami, mają trudności z uzyskaniem zatrudnienia, albo dostają prace niezgodną ze swoimi kwalifikacjami czy nieadekwatną finansowo. Brak jest atrakcyjnych ofert pracy dla ludzi w tym wieku (lub jest ich bardzo mało). Taka sytuacja związana jest ze stereotypami dotyczącymi ludzi starszych oraz tym, że panuje obecnie tzw. kultura młodości. Wyraźnie widać to w nomenklaturze, przypisującej przymiotnikowy „młody” wyjątkowo pozytywnie wartościujący charakter ${ }^{27}$. Stąd pojawiają się takie twierdzenia, jak to, że senior realizujący swoje pasje czy podejmujący aktywność ma „młody” umysł, jest „młody duchem”. Osobie starszej korzystającej z własnej mądrości i doświadczenia są odbierane - w taki symboliczny sposób - atrybuty związane z jej możliwościami, naturalnymi dla jej okresu rozwojowego. Wartość nadawana jest poprzez przypisywanie atrybutów młodości, które są wszak fikcyjnymi. Umysł młodych ludzi, mimo wszystkich swoich zalet, nie jest w stanie podołać wyzwaniom związanym z głębokimi wglądami czy transcendencją, do czego przystosowany jest umysł seniora i na co ludzie starsi pracują przez całe swoje życie, zbierając wiedzę, doświadczenia, budując samoświadomość, emocje, system wartości ${ }^{28}$. Mamy więc do czynienia ze swoistą iluzją społeczną. To, co w starości najbardziej wartościowe, musi być nazwane „młodym”, aby mogło zaistnieć w przestrzeni publicznej i być zaakceptowane jako wartość w kulturze młodości, mimo że zupełnie atrybutów młodości nie reprezentuje ${ }^{29}$.

Równolegle z kulturą młodości seniorzy muszą się zmierzyć z powszechną technicyzacją. Rozwój technologii pozwala przekraczać granice czasu, przestrzeni i ciała, pozwala realizować rzeczy niemożliwe, skraca dystanse oraz zwiększa możliwości. Umożliwia prowadzenie rozmów łączących miejsca po dwóch stronach kuli ziemskiej, przemieszczanie się i przekazywanie informacji w szybkim tempie ${ }^{30}$. Przekraczane są granice ciała, osoby mające kłopot z funkcjonowaniem mogą je usprawnić, korzystając z nowoczesnych rozwiązań technologicznych (np. zaawansowanych im-

${ }^{26}$ Encyklopedia Zarządzania, https://mfiles.pl/pl/index.php/Wykluczenie spo\%C5\%82eczne (dostęp: 30.08.2017).

${ }_{27}$ Z. Bauman, Ciało i przemoc w obliczu ponowoczesności, Torun 1995.

${ }^{28}$ Poruszono: A. Sobczyk-Kubiak, Młodość czy dojrzałość - co jest wartościa we wspótczesnym świecie?, [w:] J. Zimny (red.), „Współczesne zagrożenia - wyzwania i działania”, Stalowa Wola 2016.

${ }^{29}$ N. Etcoff Przetrwaja najpiękniejsi, Warszawa 2002.

${ }^{30}$ R. Borkowski, Cywilizacja. Technika. Ekologia. Wybrane problemy XX wieku, Kraków 2001. 
plantów słuchowych). Świat się „zmniejszył”, a procesy globalizacyjne sprawiają, że mamy dostęp do praktycznie całego świata. Technologia ułatwia życie, zmienia rzeczywistość i ją współtworzy ${ }^{31}$, budując zupełnie nowe wymiary, takie jak cyberprzestrzeń $^{32}$. Wpływa na wszystkie aspekty życia ludzkiego, od komunikacji, medycyny, pracy zawodowej, po duchowość czy seksualnośćc ${ }^{33}$. Kłopot dla ludzi starszych polega na tym, że urodzili się w zupełnie innej rzeczywistości, zdecydowanie bardziej ubogiej w rozwiązania technologiczne. Nie potrafią korzystać z nowoczesnych urządzeń lub nie mają do nich dostępu z powodów finansowych. Ponieważ bardzo duży obszar współczesności „dzieje się” za pomocą technologii, oznacza to kolejny obszar wykluczenia - wykluczenie cyfrowe ${ }^{34}$. Stanowi to kolejne wyzwanie dla starszych osób - aby rozumieć młodsze pokolenia i nadążać za nimi, muszą dotrzymywać im kroku i po prostu „być w kontakcie”. Wykształciła się potrzeba zdobycia nowych umiejętności: obsługiwania nowoczesnych urządzeń, posługiwania się technologiami (jak np. Internet) czy nauczenia się języka obcego, ponieważ w wyniku procesów globalizacyjnych starsi często mają swoich najbliższych poza granicami kraju. Współcześnie czas starzenia się jest więc o wiele bardziej wymagający niż jeszcze kilkadziesiąt lat temu. Należy przystosować się nie tylko do zmieniającego się dynamicznie ciała, ale także do intensywnie zmieniającej się rzeczywistości, a starość - do tej pory kojarząca się z okresem korzystaniem z nabytych wcześniej doświadczeń - staje się okresem intensywnego zdobywania nowych umiejętności. Ponadto wartości niesione przez cywilizację młodości i technologii nie do końca korespondują z wartościami, jakie są istotne dla pomyślnego starzenia się. Konsumpcjonizm czy chęć sprostania wyzwaniom cywilizacyjnym za wszelką cenę wręcz opóźniają gerotranscendencję i zmniejszają szansę na uzyskanie mądrości, będącej cnotą wieku podeszłego. Pogoń za indywidualizmem, egocentryzm czy ukrywanie swojej starości (np. za pomocą licznych zabiegów kosmetycznych czy operacji plastycznych), chęć dorównania młodym i brak akceptacji dla upływu czasu wywołują niebezpieczeństwo odrzucenia prawdziwego siebie, zaprzeczenia swojej naturze, utrudniają odnalezienie głębokiego sensu w życiu. Zewnętrzna presja społeczna na to, aby seniorzy podejmowali aktywności charakterystyczne dla młodych, jest bowiem silna ${ }^{35}$.

31 P. Nosal, dz. cyt.

32 K. Doktorowicz, Społeczności wirtualne - cyberprzestrzeń w poszukiwaniu utraconych więzi, http://winntbg.bg.agh.edu.pl/skrypty2/0095/059-066.html (dostęp: 7.06.2017).

33 P. Nosal, dz. cyt.

34 https://www.i-slownik.pl/5923,wykluczenie-cyfrowe-e-wykluczenie-podzial-cyfrowy/ (dostęp: 7.06.2017).

35 M. Młynarska, Jakość podeszłego wieku: jesień życia między gerotranscendencja, postawa kidult i poświęceniem, „Wspólne Tematy”, nr 11-12/2008, s. 20-28. 


\section{Rozwój osobisty}

Rozwój osobisty (samorozwój), inaczej - samodoskonalenie, obejmuje wszystkie działania, służące do podwyższenia własnych kompetencji osobistych, takich jak: samoświadomość, radzenie sobie ze stresem, poprawienie komunikacji, rozumienia i akceptacji samego siebie oraz swojego miejsca w życiu, dostrzeganie sensu istnienia, odkrywanie swoich talentów i możliwości, a także rozwijanie hobby, radzenie sobie $\mathrm{z}$ bólem emocjonalnym, dokonywanie właściwych wyborów, odniesienie sukcesu, reagowanie na sytuacje życiowe ${ }^{36}$. Brak jest jednoznacznej definicji tego zjawiska, zazwyczaj rozumiane jest ono bardzo szeroko, jako wszystkie działania, mające na celu podniesienie kompetencji osobistych człowieka. Można przytoczyć następującą definicję: rozwój osobisty to zbiór metod $i$ informacji, możliwych do indywidualnego stosowania i służący usprawnieniu ludzkiego życia w różnych jego obszarach: społecznym, poznawczym, emocjonalnym ${ }^{37}$. Odnosi się zarówno do wydarzeń zorganizowanych, typu warsztaty czy wykłady, jak i do działań podejmowanych indywidualnie przez jednostkę, takich jak głęboka refleksja, kontemplowanie przyrody, czytanie książek czy praktyki medytacyjne. Niekiedy zalicza się tu również praktyki związane z duchowością. Korzystanie z ofert zajęć warsztatowych czy grupowych różni się jednak pod względem jakości, walorów edukacyjnych oraz perspektywy od tych podejmowanych samodzielnie, z potrzeby serca. Warsztaty prowadzone przez specjalistę dostarczają nowej wiedzy, uczą nowych technik czy umiejętności bądź korygują ich stosowanie. Nie zastąpią natomiast indywidualnej i pogłębionej refleksji nad własnym życiem. Najlepiej byłoby, z punktu widzenia różnorodności uzyskiwanych efektów, łączyć aktywność indywidualną z korzystaniem z oferty zajęciowej i edukacyjnej. Na potrzeby tego artykułu autorka zdecydowała się natomiast na nieco węższe ujęcie pojęcia rozwoju osobistego i ograniczenie go do analizy działań zorganizowanych i oferowanych na rynku usług, czyli warsztatów, wykładów, webinarów i kursów stacjonarnych oraz cyfrowych.

Nurt rozwoju osobistego czerpie w dużej mierze z osiągnięć psychologii pozytywnej, która wskazuje na to, jak pracować w oparciu o zasobach i mocne strony człowieka, wzmacniać indywidualne poczucie szczęścia, integrować struktury, postrzegać świat i swoje miejsce w kategoriach pozytywnych, szukać sensu w życiu i poszerzać swoją samoświadomość, dostrzegać świat takim, jakim jest naprawdę i korzystać z jego możliwości, poprawiać jakość życia, rozpoznawać swój potencjał i czerpać z niego, pozostając w zgodzie ze sobą ${ }^{38}$. W kulturze młodości i cywilizacji, w której promowane są takie wartości, jak ciało, konsumpcjonizm, technologia, nowoczesność, szybkie tempo i innowacje, prężnie działający rynek usług rozwoju osobistego

${ }^{36}$ http://krystynakieler.pl/czym-jest-rozwoj-osobisty/ (dostęp: 7. 06. 2017).

${ }^{37}$ http://blog.krolartur.com/rop-1-1-czym-jest-rozwoj-osobisty/ (dostęp: 17.08.2017).

${ }_{38}$ B. Gulla, K. Tucholska, Psychologia pozytywna: cele naukowo-badawcze i aplikacyjne oraz sposób ich realizacji, [w:] Studia z psychologii KUL, Tom 14, 2007, s. 133-152. 
jest naturalną odpowiedzią na potrzeby ludzi związane z duchowością, skierowaniem do swojego wnętrza. Wydawałoby się, że założone powyżej cele wpisują się idealnie w potrzeby okresu rozwojowego, jakim jest okres starzenia się i starości, zważywszy na doniosłość i ostateczność tego okresu. Ponadto wydawałoby się, że obszar usług rozwoju osobistego mógłby w dużym stopniu ułatwić, czy nawet umożliwić podołanie wyzwaniom, jakie stawia przed starszymi współczesność. Jednak brak jest oferty skierowanej do tej grupy wiekowej i biorącej pod uwagę specyficzne potrzeby starszych osób. Poza nielicznymi wyjątkami, oferta jest niedopasowana do seniorów pod względem dostępności, także finansowej. Część ofert jest promowana i rozpowszechniana, a nawet odbywa się przez Internet, do którego starsi ludzie mają ograniczony dostęp. Lepiej wygląda sytuacja osób starszych w dużych miastach, w których funkcjonują Kluby Seniora, stowarzyszenia i fundacje, które starają się o fundusze na zajęcia do nich skierowane. Łatwiej też dotrzeć na zajęcia, bo rozbudowany jest system komunikacji miejskiej. Sytuacja seniorów w małych miasteczkach i wioskach jest pod tym względem o wiele gorsza. Starsi ludzie poszukujący aktywności na terenach wiejskich mają do dyspozycji zazwyczaj działania hobbystyczne lub artystyczne. Zdaniem autorki, ważne potrzeby seniorów związane $\mathrm{z}$ ich cyklem rozwojowym w zasadzie są pomijane, mimo że oferta dla pozostałych grup rozwojowych jest bardzo bogata. Istnieje na rynku stosunkowo silnie rozbudowana oferta związana z jednym aspektem senioralnej aktywności: pełnieniem roli babci/dziadka (np. Latające Babcie w Łodzi czy Letnia Szkoła Superbabci i Superdziadka w Lublinie). Natomiast brak jest oferty skierowanej do starszych osób poruszającej na przykład trudny temat akceptacji śmierci, mimo że prowadzi się takie zajęcia dla terapeutów czy dla chorych onkologicznie. Niewątpliwie przeprowadzenie dokładnej analizy oferty dla starszych osób byłoby ciekawym wyzwaniem badawczym.

Aby umożliwić seniorom uczestniczenie i dostęp do tego rodzaju metod pracy nad sobą i wspierania samego siebie, potrzeba przede wszystkim edukowania starszych w dziedzinie korzystania $\mathrm{z}$ nowych technologii oraz umożliwienia im korzystania $\mathrm{z}$ urządzeń typu laptop czy komputer PC. Tego rodzaju działania mogłyby stać się celem pracy organizacji pozarządowych czy klubów seniorów, ponieważ barierę finansową można ominąć poprzez uzyskiwanie dotacji instytucjonalnych. Należy również uświadamiać osobom starszym jakie mają możliwości rozwojowe i w jaki sposób mogą je realizować, jak budować swoje pasje, zachowując jednocześnie potrzebny dystans. Według autorki niniejszej pracy zapotrzebowanie jest duże. Temat rozwoju osobistego osób starszych trzeba podejmować jak najczęściej, gdyż jest to obszar do tej pory bardzo słabo zagospodarowany. 


\section{Podsumowanie}

Rozwój osobisty, rozumiany jako wspieranie siebie, szukanie sensu w życiu, rozwijanie kompetencji ułatwiających odczuwanie szczęścia oraz postrzeganie swojego życia jako sensownego i cennego, a samego siebie jako wartościowej jednostki ludzkiej, mógłby być narzędziem ułatwiającym seniorom odnalezienie się w trudnej rzeczywistości, pozytywną adaptację do starości oraz realizowanie zadań związanych z okresem rozwojowym, jakim ona jest. Brakuje jednak dobrze zorganizowanej oferty, atrakcyjnej cenowo i merytorycznie dla tej grupy wiekowej. Istnieje grupa seniorów, którzy nie potrzebują dodatkowego wsparcia i w swoim rozwoju doskonale radzą sobie sami, natomiast osoby, które doświadczają negatywnych aspektów starości i nie potrafią sobie poradzić za pomocą indywidualnych metod adaptowania się, mogłyby uzyskać poprzez takie zajęcia pomoc. Część kursów, warsztatów, wykładów czy szkoleń odbywa się wirtualnie, co ogranicza dostęp do nich starszych ludzi ze względu na zjawisko wykluczenia cyfrowego. Zdaniem autorki potrzebne jest podjęcie odpowiednich działań w celu umożliwienia seniorom uczestnictwa w zajęciach rozwoju osobistego, a najważniejszym postulatem tego artykułu jest zwrócenie uwagi na zjawisko wykluczenia osób starszych również w tym obszarze. Seniorzy powinni mieć możliwość decydowania, którą ścieżkę rozwoju dla siebie wybiorą, natomiast ze względu na liczne ograniczenia w dostępności często takiej możliwości nie mają.

\section{Bibliografia}

Bauman Z., Ciało i przemoc w obliczu ponowoczesności, Wydawnictwo Uniwersytetu Mikołaja Kopernika, Toruń 1995.

Borkowski R., Cywilizacja. Technika. Ekologia. Wybrane problemy XX wieku, AGH Uczelniane Wydawnictwo Naukowo-Dydaktyczne, Kraków 2001.

Bromley D., Psychologia starzenia się, PWN, Warszawa 1969.

Brzezińska A., Psychologiczne portrety człowieka, GWP, Gdańsk 2005.

Doktorowicz K., Społeczności wirtualne - cyberprzestrzeń w poszukiwaniu utraconych więzi, http://winntbg.bg.agh.edu.pl/skrypty2/0095/059-066.html (dostęp: 7.06.2017).

Encyklopedia Zarządzania, https://mfiles.pl/pl/index.php/Wykluczenie_spo\%C5\%82eczne (dostęp: 30.08.2017).

Etcoff N., Przetrwają najpiękniejsi. Wszystko, co nauka mówi o ludzkim pięknie, Wydawnictwo CIS, Warszawa 2002.

Gulla B., Tucholska K., Psychologia pozytywna: cele naukowo-badawcze i aplikacyjne oraz sposób ich realizacji, [w:] Studia z psychologii KUL, Tom 14, 2007, s. 133-152. 
Hamilton I., Psychologia starzenia się. Wprowadzenie, Zysk i Spółka, Poznań 2006.

Mamak-Zdanecka M.,"Pomyślne starzenie się" w wymiarze demograficznym, społecznym, gerontologicznym, [w:] M. Synowiec-Piłat, B. Kwiatkowska, K. Borysławski (red.), Inkluzja czy ekskluzja? Człowiek stary w społeczeństwie, Wydawnictwo Uniwersytet Medyczny, Wrocław 2015, s. 19-36.

Miszczak E. Aktywność seniorów sposobem przeciwdziałania negatywnym skutkom procesu starzenia się, [w:] D. Kałużna, P. Szukalski (red.), Jakość życia seniorów XXI wieku. Ku aktywności, Wydawnictwo Uniwersytetu Łódzkiego, Łódź 2010, s. 24-33.

Młynarska M., Jakość podeszłego wieku: jesień życia między gerotranscendencją, postawa kidult i poświęceniem, „Wspólne Tematy”, nr 11-12/2008, s. 20-28.

Nelson T., Ageism and discrimination, [w:] J. Birren (red.), Encyclopedia of Gerontology, Wydawnictwo Academic Press, San Diego 2007.

Nosal P., Technologia i sport, Wyd. Naukowe Katedra, Poznań 2014.

Scharlach A., Robinson B., Curriculum Module on the Aging Process University of California, http://garnet.berkleley.edu/ageing/ModuleProcess.html (dostęp: 3.03.2015).

Sobczyk-Kubiak A., Młodość czy dojrzałość - co jest wartościa we współczesnym świecie?, [w:] J. Zimny (red.), Współczesne zagrożenia - wyzwania i działania, KUL, Stalowa Wola 2016.

Steuden S., Psychologia starzenia się, PWN, Warszawa 2011.

Straś-Romanowska M., Późna dorosłość. Wiek starzenia się, [w:] B. Harwas-Napierała, J. Trempała (red.), Psychologia rozwoju człowieka. Charakterystyka okresów życia, PWN, Warszawa 2004, s. 263-292.

Sygit E., Dlaczego dyskryminujemy osoby starsze, „Psychogeriatria Polska”, nr 5(4)/2008, s.153-158.

Szarota Z., Gerontologia społeczna i oświatowa. Zarys problematyki, Wydawnictwo Naukowe Akademii Pedagogicznej, Kraków 2004.

Szukalski P. Stan zdrowia Polek i Polaków na przedpolu starości, [w:] P. Szukalski (red.), To idzie starość. Postawy osób w wieku przedemerytalnym. Raport $z$ badań, Instytut Spraw Publicznych, Warszawa 2008, s. 7-29.

Zakowicz I., Starzenie się w kulturze młodości. Wybrane strategie obrazowania starości w reklamie. „Ogrody Nauk i Sztuk”, nr 2/2012, s. 391-398.

Zierkiewicz E, Kowalczyk I., Konsumentka czy konsumowana, „Kultura Popularna”, nr 2/2002, s. 119-124.

https://www.i-slownik.pl/5923,wykluczenie-cyfrowe-e-wykluczenie-podzial-cyfrowy/ (dostęp: 7.06.2017).

http://krystynakieler.pl/czym-jest-rozwoj-osobisty/ (dostęp: 7.06.2017).

http://blog.krolartur.com/rop-1-1-czym-jest-rozwoj-osobisty/ (dostęp: 17.08.2017). 


\section{The area of personal development as one of the areas of exclusion of older people}

Abstract: Old age is a period of human life, in which may occur many physiological, psychological and social changes. Individual faces the challenge typical for this period of development: retirement, adaptation to old age, transcendental wisdom and finally preparation for departure. Aging individuals are affected by phenomenon like ageism or gerontophobia. Aging process hasn't changed over the years, but the way in which people are becoming old and circumstances of aging have altered a lot. Modern civilization of the youth and technology, force the elderly people to take a new tasks: operation new devices, functioning in new digital environment. It's the time of intensive learning, not giving up can lead to digital exclusion. Personal development is other factor of digital exclusion and marginalization. Moreover, the offer of an employment do not take into consideration needs of elderly people and the way to access to it may impede entering to labour market.

Keywords: ageism, personal development, old age.

\footnotetext{
About the author: MA Aleksandra Sobczyk-Kubiak - psychologist, sociologist and pedagogue, life coach and personal development trainer. Since 2016, Ph.D. student at the Institute of Sociology at the Faculty of Economics and Sociology of the University of Lodz. She is interested in the impact of individual and cultural exertion, behavioral dependence, positive psychology, personal development and growth. Prefers narrative methods of working with a human. Specialist in Rational Behavioral Therapy.
} 


\author{
Dariusz Sarzała* \\ Uniwersytet Warmińsko-Mazurski w Olsztynie \\ sarzalad@op.pl
}

\title{
Fonoholizm wśród młodzieży szkolnej jako nowa forma zachowań ryzykownych
}

\begin{abstract}
Streszczenie: $\mathrm{W}$ artykule przedstawione zostało zjawisko nadmiernego korzystania z telefonu komórkowego przyjmującego postać nowego cyberuzależnienia, określanego mianem fonoholizmu. Autor skoncentrował się głównie na problematyce związanej z możliwością uzależnienia się od tego urządzenia. Przedstawił objawy fonoholizmu oraz negatywne konsekwencje dla zdrowia i rozwoju psychospołecznego młodzieży szkolnej w kontekście zachowań ryzykownych. Podkreślona została również potrzeba wyodrębnienia kryteriów diagnostycznych tego uzależnienia. W artykule autor wskazał także na rolę rodziny oraz szkoły w przeciwdziałaniu temu zjawisku.
\end{abstract}

Słowa kluczowe: cyberprzestrzeń, cyberuzależnienie, fonoholizm, nadmierne korzystanie z telefonu komórkowego, uzależnienie od telefonu komórkowego, młodzież szkolna, zachowania ryzykowne

\section{Wstęp}

Następujący w ostatnich latach dynamiczny rozwój technologii cyfrowych spowodował, że stały się one nie tylko narzędziami codziennego użytku współczesnego człowieka, ale też synonimem cywilizacyjnego postępu. Jednym z najbardziej wyrazistych przykładów jest między innymi telefonia komórkowa, która rozpowszechnia

* Dariusz Sarzała - pedagog i filozof, doktor nauk humanistycznych. Adiunkt w Katedrze Pedagogiki Resocjalizacyjnej na Wydziale Nauk Społecznych Uniwersytetu Warmińsko-Mazurskiego w Olsztynie. Swe zainteresowania badawcze koncentruje na tematyce dotyczącej niedostosowania społecznego oraz resocjalizacji. Zajmuje się również badaniem uzależnień behawioralnych i nowych zjawisk dewiacyjnych występujących w cyberprzestrzeni oraz ich uwarunkowań. Autor, współautor i współredaktor ponad 120 artykułów naukowych i książek dotyczących wymienionych obszarów tematycznych, opublikowanych w Polsce i za granicą. 
się w tempie szybszym niż jakiekolwiek inne wcześniejsze technologie ${ }^{1}$. Jak wskazują statystyki, korzysta z niej na świecie ponad miliard ludzi niemalże w każdym przedziale wiekowym².

Należy jednak podkreślić, że coraz większa dostępność do telefonii komórkowej wpływa na kształtowanie się nie tylko nowych pozytywnych aktywności i sposobów komunikacji w życiu codziennym³ ${ }^{3}$ lecz także staje się źródłem licznych zachowań dewiacyjnych oraz nowych problemów społecznych i wychowawczych. Niekontrolowane, nieodpowiednie lub nadmierne użycie telefonu komórkowego powoduje problemy behawioralne i emocjonalne $e^{4}$ oraz stwarza niebezpieczeństwo uzależnienia się od tego urządzenia 5 . Zjawisko to określane jest często w literaturze przedmiotu jako fonoholizm i niesie ze sobą szereg zagrożeń dla psychospołecznego rozwoju człowieka ${ }^{6}$.

W dalszej części niniejszego opracowania przedstawiono zjawisko nadmiernego korzystania z telefonu komórkowego, ze szczególnym uwzględnieniem problemu uzależnienia się od tego urządzenia.

Fonoholizm będzie analizowany jako zachowanie ryzykowne, definiowane przez badaczy zajmujących się tą problematyką jako działanie podejmowane $z$ własnej woli, którego skutki są niepewne, z możliwością wystąpienia dającego się określić negatywnego wpływu na stan zdrowia ${ }^{7}$. Podkreślmy jednocześnie, że lista zachowań ryzykownych jest długa, najczęściej występujące $\mathrm{z}$ nich to: palenie tytoniu, zaburzone odżywianie się, spożywanie alkoholu, używanie narkotyków, zachowania samobójcze, nieumyślne urazy ciała, przestępczość, przemoc, ciąże nieletnich, choroby przenoszo-

${ }^{1}$ P. Farago, iOS and Android Adoption Explodes Internationally 2012, http://blog.flurry.com/ bid/88867/iOS-and-Android-Adoption-Explodes-Internationally.

2 Strategy Analytics, Worldwide Smartphone Population Tops 1 Billion in Q3 2012. Wireless Smartphone Strategies 2012, http://blogs.strategyanalytics.com/WDS/post/2012/10/17/Worldwide-Smartphone-Population-Tops-1-Billion-in-Q3-2012.aspx.

${ }^{3}$ H. Lacohèe, N. Wakeford, I. Person, A Social History of the Mobile Telephone with a View of its Future, „BT Technology Journal”, nr 21(3)/2003, s. 203-211.

${ }^{4}$ M. Chóliz, Mobile phone addiction: a point of issue, „Addiction”, $\mathrm{nr}$ 105(2)/2010, s. 373-374.

${ }^{5} \mathrm{Ch}$. Tossell i in, Exploring Smartphone Addiction: Insights from Long-Term Telemetric Behavioral Measures, ,iJIM”, nr 9/2015, s. 37-43; J. Billieux, Problematic Use of the Mobile Phone: A Literature Review and a Pathways Mode, „Current Psychiatry Reviews”, nr 4/2012, s. 1-9; D. Sarzała, Telefon komórkowy jako nowe źródło zagrożeń, [w:] M. Jędrzejko, D. Sarzała (red.), Człowiek i zagrożenia, Pułtusk 2010, s. 219-238.

${ }^{6}$ S. Kozak, Patologia fonoholizmu - przyczyny, skutki i leczenie uzależnienia dzieci i młodzieży od telefonu komórkowego, Difin SA, Warszawa 2013; W. Wiaderek, Gdy brak zasiegu, „Problemy Opiekuńczo-Wychowawcze”, nr 7/2012, s. 49-50; M. Figurska, Haloooo... tu fonoholik, „Charaktery”, nr 4/2012, s. 82-85; R. Mysior, Fonoholizm - w kręgu uzależnienia, „Problemy Opiekuńczo-Wychowawcze", nr 10/2015, s. 28-33; E. Guzowska, Zagrożenia wynikające z korzystania z telefonów komórkowych, „Problemy Opiekuńczo-Wychowawcze”, nr 7/2015, s. 46-50; A. Baranowska, Fonoholizm wśród uczniów, „Wychowawca”, nr 2/2016, s. 20-21.

7 Zob. szerzej: Ch. E. Irwin, The Theoretical Concept of At-Risk Adolescents, „Adolescent Medicine: State of the Art Reviews", nr 1/1990, s. 1-14; R. Jessor, New perspectives on adolescent risk behavior, Cambridge University Press, New York 1998. 
ne drogą płciową, ucieczki z domu i bezdomność młodzieży, nieosiąganie potencjalnych sukcesów szkolnych i porzucenie szkoły ${ }^{8}$ czy przyjmowanie środków psychoaktywnych w postaci leków uspokajających i nasennych, środków wziewnych, sterydów anabolicznych, dopalaczy oraz rożnych połączeń leków lub narkotyków z alkoholem9

Przeprowadzona zostanie analiza terminologiczna zjawiska fonoholizmu, a także jego kryteriów diagnostycznych oraz przyczyn i skutków w kontekście zachowań ryzykownych, stanowiących zagrożenie dla zdrowia i rozwoju psychospołecznego młodego człowieka. Ponadto uwaga zostanie zwrócona na rolę i zadania środowiska rodzinnego oraz szkolnego w etiologii fonoholizmu i przeciwdziałaniu zachowaniom związanym $\mathrm{z}$ nadmiernym korzystaniem przez młodzież szkolną z telefonów komórkowych.

\section{Fonoholizm a cyberuzależnienie}

W ostatnich latach coraz częściej mówi się nie tylko o nadmiernym lub nałogowym korzystaniu z telefonii komórkowej, lecz nawet o uzależnieniu od telefonu komórkowego jako jednej z postaci cyberuzależnienia ${ }^{10}$. Wielu użytkowników telefonów komórkowych (dotyczy to zwłaszcza młodzieży) ma bowiem problemy z kontrolowaniem czasu, jaki poświęca na korzystanie z nich, i w konsekwencji narażone jest na uzależnienie się od tego typu urządzeń. W celu pełniejszego zrozumienia analizowanej problematyki warto w tym miejscu podkreślić, że cyberuzależnienie stało się w dobie rozwoju technologii cyfrowych bardzo dynamicznie rozprzestrzeniającym się zjawiskiem, które możemy interpretować jako uzależnienie od przedmiotów (multimediów elektronicznych) i czynności z nimi związanych oraz uzależnienie od treści, jakie są przekazywane przez tego rodzaju media.

W literaturze przedmiotu cyberuzależnienie postrzegane jest jako nowy rodzaj uzależnienia bez substancji uzależniającej, czyli uzależnienie psychologiczne - addiction (zmuszające do poszukiwania przedmiotu lub wykonywania określonej czynności), w przeciwieństwie do uzależnienia od substancji chemicznej - dependence (w przypadku którego organizm, aby mógł funkcjonować, domaga się określonej substancji ${ }^{11}$. W przypadku cyberuzależnienia substancja chemiczna nie odgrywa więc żadnej roli, a problemem staje się określony przedmiot lub - najczęściej - zachowania i działania związane z jego użytkowaniem.

${ }^{8}$ J. A. Grunbaum i inni, Youth Risk Behavior Surveillance-United States, 2003, „MMWR Surveill Summary", nr 53(2)/2004, s. 1-96.

9 M. Z. Jędrzejko, D. Sarzała, A. Taper, A. Szwedzik, Nowe przestrzenie i modele ryzyka, [w:] M. Z. Jędrzejko, R. Sieroń (red.), Zachowania ryzykowne nastolatków. Raport z badań, s. 117-138.

${ }^{10}$ C. Guerreschi, Nowe uzależnienia, Wydawnictwo Salwator, Kraków 2005, s. 197-198; L. Cierpiałkowska, Kierunki rozwoju współczesnej psychologii uzależnień, [w:] L. Cierpiałkowska (red.), Oblicza współczesnych uzależnień, Wydawnictwo Naukowe UAM, Poznań 2006, s. 21.

${ }^{11}$ C. Guerreschi, dz. cyt., s. 26; M. Chóliz, Mobile phone addiction: a point of issue, „Addiction”, nr 105(2)/2010, s. 373-374. 
Należy jednocześnie zaznaczyć, ze zjawisko cyberuzależnienia jest coraz częściej pojawiającym się problemem szczególnie wśród nastolatków, zarówno w krajach europejskich, jak i Stanach Zjednoczonych Ameryki Północnej oraz wielu innych państwach na świecie ${ }^{12}$. Stworzenie dokładnej definicji tego terminu przysparza jednak dużo trudności, ponieważ nie został on jeszcze ujęty w obowiązującej klasyfikacji zaburzeń psychicznych. W ostatnich latach podejmowane są jednak próby wyodrębnienia kryteriów diagnostycznych służących m.in. do rozpoznawania Zespołu Uzależnienia od Internetu (ZUI), a oparte są one najczęściej na wskaźnikach uzależnień zawartych w Diagnostycznym i Statystycznym Podręczniku Zaburzeń Psychicznych (Diagnostic and Statictical Manual of Mental Disorders - DSM-V) oraz Międzynarodowej Statystycznej Klasyfikacji Chorób i Problemów Zdrowotnych (Interntional Classification of Mental and Behavioural Disorders - ICD-10).

Na problem cyberuzależnienia wskazują także od wielu lat zajmujący się tą problematyką badacze - zarówno zagraniczni, jak i polscy (m.in. Young 1996; Goldberg 1999; Beard 2001; Shapira 2003; Guerreschi 2005; Jakubik 2003; Łuczak 2009). Skalę narastania problemu pokazuje także coraz większa liczba programów terapeutycznych kierowanych do osób dotkniętych tym uzależnieniem ${ }^{13}$.

W ostatnich latach coraz większy problem stanowi nowa postać cyberuzależnienia, związana z nadmiernym korzystaniem z telefonu komórkowego. Uzależnienie to nazywane jest najczęściej fonoholizmem i przejawia się przede wszystkim utratą kontroli nad zachowaniami dotyczącymi przedmiotu uzależnienia, jaki stanowi w tym przypadku telefon komórkowy, oraz nieodpartą potrzebą korzystania z niego. Przedmiotem uzależnienia są także zachowania i działania związane $\mathrm{z}$ jego użytkowaniem.

Fonoholizm dotyka użytkowników telefonów komórkowych zarówno na poziomie behawioralnym (powtarzanie określonych zachowań), jak i emocjonalnym (użytkownik tak jest pochłonięty telefonem komórkowym, że nie jest w stanie się powstrzymać od ciągłego z niego korzystania). Jeden z prekursorów badań zjawiska cyberuzależnienia Mark Griiffths ${ }^{14}$ podkreśla, że na uzależnienie składa się określona liczba elementów, zwłaszcza takich, jak: wyrazistość emocjonalnego podporządko-

${ }_{12}$ Children's use of mobile phones - An international comparison 2012, GSM Association and the Mobile Society Research Institute within NTT DOCOMO Inc, Japan 2013, https://www.gsma. com/publicpolicy/wp-content/uploads/2012/03/GSMA ChildrensMobilePhones2012WEB.pdf (dostęp: 29.06.2017); F. Lenihan, Computer addiction - a sceptical view Invited commentary on: Lost online, „Advances in Psychiatric Treatment”, nr 13(1)/2006, s. 31-33; K. Young, Internet addiction over the decade: A personal look back; „World Psychiatry”, nr 9(2)/ 2010; A. Tsitsika, E. Tzavela, F. Mavromati and the EU NET ADB Consortium, Research on Internet addictive behaviours among European adolescents, (2012), www.eunetadb.eu (dostęp: 28.06.2017); C. Y. Yang, T. Sato, N. Yamawaki, M. Miyata, Prevalence and risk factors of problematic Internet use: A cross-national comparison of Japanese and Chinese university students, „Transcultural Psychiatry”, nr 50(2)/2013, s. 263-279.

${ }_{13}$ J. Suler, Therapy and Support Groups, http://users.rider.edu/ suler/psycyber/ (dostęp: 29.06.2017); A. Jakubik, Zespół uzależnienia od Internetu (ZUI) - Internet Addiction Syndrome (IAS), 2003, http://www.psychologia.edu.pl.

${ }^{14}$ M. Griiffths, Gry i hazard. Uzależnienia dzieci w okresie dorastania, GWP, Gdańsk 2004. 
wania, zmiana nastroju, tolerancja dawkowania, konflikt interaktywny lub intrapsychiczny czy też nawrót. Wiele zachowań zaobserwowanych wśród młodzieży szkolnej korzystającej z telefonów komórkowych spełnia powyższe kryteria. Prowadzone badania sygnalizują, że uczniowie nadmiernie korzystający ze smartfonów mają skłonność do takich stanów, jak niestabilność emocjonalna, deficyt uwagi, depresja, złość i brak kontroli ${ }^{15}$.

Należy jednak zaznaczyć, że o uzależnieniu możemy mówić dopiero w sytuacji, w której korzystanie z określonego medium zaczyna przeszkadzać w codziennym funkcjonowaniu (w nauce, pracy zawodowej, realizacji zainteresowań, kontaktach interpersonalnych) oraz kiedy staje się substytutem rzeczywistego życia oraz powoduje konsekwencje psychiczne, fizyczne i społeczne ${ }^{16}$.

\section{Czynniki osobowościowe sprzyjające fonoholizmowi}

Wymienić można wiele czynników sprzyjających występowaniu przejawów cyberuzależnienia w postaci fonoholizmu. Badacze tej problematyki podkreślają, że istnieje związek pomiędzy cyberuzależnieniem a predyspozycjami osobistymi jednostki. Wskazuje się, że osoby nadmiernie korzystające z technologii cyfrowych charakteryzują się niższym poziomem ekstrawersji oraz wyższym poziomem neurotyczności ${ }^{17}$. Wyniki badań wskazują także na istniejący związek pomiędzy tego rodzaju uzależnieniem a poziomem wrażliwości emocjonalnej oraz tendencją do powstawania stanów depresyjnych ${ }^{18}$.

Osoby zagrożone cyberuzależnieniem to także ludzie cierpiący z powodu samotności ${ }^{19}$ oraz ci, którzy nie mają czasu na kontakty społeczne. Fonoholizmem zagrożone są również osoby $\mathrm{z}$ wysokim poziomem stresu, posiadające ograniczony krąg kontaktów społecznych, a nawet - izolowane społecznie. Rozmowy telefoniczne sta-

${ }^{15}$ Ch. Park, Y. R. Park, The Conceptual Model on Smart Phone Addiction among Early Childhood, ,International Journal of Social Science and Humanity”, nr 2(4)/2014, s. 149; K. Young, Internet addiction: The emergence of a new clinical disorder, „CyberPsychology \& Behavior”, nr 3/1996, s. $237-244$.

${ }^{16}$ D. Sarzała, Cyberprzestrzeń a problem uzależnień, [w:] E. Łuczak (red.), Nowe oblicza uzależnień, UWM, Olsztyn 2009, s. 137.

${ }_{17}$ A. Augustynek, Uzależnienia komputerowe. Diagnoza, rozpowszechnienie, terapia, Difin, Poznań 2010; M. J. Barłóg, Uzależnienie od Internetu i jego osobowościowe determinanty, „Hygeia Public Health", nr 50(1)/2015, s. 197-202.

${ }_{18}$ O. Cagan, A. Unsal, N. Celik, Evaluation of college students the level of Addiction to Cellular Phone and Investigation on the Relationship between the Addiction and the Level of Depression, „Procedia - Social and Behavioral Sciences”, nr 114 (21)/2014, s. 831-839; S. Thomée, A. Harenstam, M. Hagberg, Mobile phone use and stress, sleep disturbances, and symptoms of depression among young adults: a prospective cohort study, „BMC Public Health”, nr 11(66)/2011.

${ }_{19}$ N. A. Dowling, M. Brown, Commonalities in the psychological factors associated with problem gambling and Internet dependence, in Cyberpsychology, „Behavior, and Social Networking”, nr 4(13)/2010, s. $437-441$. 
nowią dla nich formę niwelowania deficytów w sferze funkcjonowania społecznego, a częste korzystanie z telefonu staje się substytutem relacji z innymi ludźmi. Ponadto wśród użytkowników telefonów komórkowych przejawiających podatność na uzależnienie się od korzystania z tych urządzeń wymienia się także osoby z zaniżoną własną wartością i niską samooceną ${ }^{20}$. W przypadku takich osób korzystanie z telefonu komórkowego może stanowić jedyny sposób na zainteresowanie sobą innych ludzi oraz utrzymywanie z nimi bezpiecznych relacji.

\section{Kulturowe aspekty fonoholizmu}

W analizie źródeł i uwarunkowań fonoholizmu nie można pominąć tendencji współczesnej kultury, która jest nośnikiem preferowanych wartości będących wyznacznikami społecznego funkcjonowania człowieka ${ }^{21}$. Zwróćmy zwłaszcza uwagę na przemiany zachodzące w sferze kultury. Jak podkreśla Wolfgang Brezinka,

współczesny człowiek ugina się pod ogromem chaosu kulturowego, zawierającego (dop. - D. S.) [...] w sobie przeróżne tradycje, które do siebie nie pasują: religijne, ateistyczne, ukierunkowane na pracę i przyjemność, elitarne i egalitarne, regionalne i narodowe lub ponadnarodowe itp. Wiele z nich wyklucza się nawzajem, wszystkie do siebie werbują, który wynika przede wszystkim, wszystkie zmieniają się pod wpływem duch $\mathrm{czasu}^{22}$.

W rzeczywistości społeczno-kulturowej dominują jednocześnie tendencje indywidualistyczne i racjonalistyczne oraz pluralizm wartości i propozycji etycznych. Stykamy się jednocześnie z coraz większą różnorodnością informacji, ofert kulturowych i form ekspresyjnego oddziaływania. W wielu przypadkach mamy także do czynienia z przejawami kultury masowej niskiej jakości ${ }^{23}$. Następuje także dominacja wartości konsumpcyjnych, materialnych, instrumentalnych, co przy jednoczesnej bezrefleksyjnej tolerancji i akceptacji w wielu przypadkach prowadzi do nihilizmu, sceptycyzmu oraz ideowej pustki, a także staje się źródłem uzależnień i podejmowania wielu innych zachowań ryzykownych. Wyraźnie zaczyna dominować konsumpcyjny styl

20 E. J. Pedrero Pérez, M. T. Rodríguez Monje, J. M. Ruiz Sánchez De León, Mobile phone abuse or addiction. A review of the literature, "Adicciones”, nr 24(2)/2012, s. 139-152; O. Peters, S. B. Allouch, Zawsze w kontakcie: badanie podłużne pola komunikacji mobilnej, „Polityka Telekomunikacja” 2005, T. 22, s. 239-256.

${ }^{21}$ D. Sarzała, Wartości a społeczne funkcjonowanie człowieka, [w:] E. Jarmoch, A. W. Świderski, I. A. Trzpil (red.), Bezpieczeństwo człowieka a wartości, T. 1, Aspekty filozoficzne i edukacyjne, Wydawnictwo Akademii Podlaskiej, Siedlce 2010, s. 187-205.

22 W. Brezinka, Wychowywać dzisiaj: zarys problematyki, Wydawnictwo WAM, Kraków 2007, s. 11 .

${ }_{23}$ M. Z. Jędrzejko, „Zawirowany” świat ponowoczesności. „Swirly” World of Postmodernity, Wydawnictwo Aspra JR, Warszawa - Milanówek 2015 , s. 72. 
życia, przejawiający się głównie w orientacji ukierunkowanej na posiadanie coraz większej ilości dóbr materialnych.

Szczególną uwagę należy zwrócić na kulturę masową zwaną również popkulturą, kulturą popularną lub kulturą codzienności ${ }^{24}$, która stanowi jednocześnie ważny element procesu socjalizacji młodego pokolenia. Kultura masowa rozpowszechniana jest przede wszystkim za pośrednictwem mass mediów, a zwłaszcza technologii cyfrowych; obejmuje coraz większy zasięg oddziaływania i odbierana jest przez bardzo szeroki krąg osób, reprezentujących różnorodne środowiska społeczne. Warto jednocześnie zwrócić uwagę na charakterystyczną cechę współczesnej kultury masowej - szybkość i natychmiastowość posiadania jej wytworów. Z powodu tej konkretnej cechy niektórzy badacze nazywają ją kulturą typu instant i wskazują, że jej symbolem jest następująca triada: fast food, fast sex, fast car, której dopełnieniem stała się szybka komunikacja za pomocą telefonu komórkowego, telewizji, faksu czy Internetu, która spełnia oczekiwania natychmiastowości i oszczędności czasu ${ }^{25}$.

Zasygnalizowane powyżej cechy niewątpliwie wypływają na kształtowanie tożsamości oraz marzeń i zachowań współczesnego konsumenta ${ }^{26}$. W związku z tym zainteresowanie młodych ludzi koncentruje się głównie wokół atrakcyjnych dóbr materialnych, zwłaszcza tych, które są wyznacznikami „,nowoczesnego” stylu życia. Jego nieodłącznym elementem stało się m.in. korzystanie z telefonu komórkowego wyposażonego w najnowsze funkcje i aplikacje. Zaznaczmy jednocześnie, że dynamiczny postęp w sferze konstrukcji komórkowych aparatów telefonicznych systematycznie wzbogaca je o kolejne funkcje użytkowe ${ }^{27}$.

Atrakcyjne stało się już samo posiadanie najnowszego modelu telefonu komórkowego i korzystanie z jego różnych funkcji i aplikacji. Właściciel telefonu komórkowego najnowszej generacji jest postrzegany jako osoba nowoczesna, orientująca się w trendach, posiadająca atrakcyjną sieć licznych i ważnych kontaktów społecznych. Częste odbieranie telefonu i prowadzenie wielu rozmów świadczy nie tylko o szerokim gronie przyjaciół i znajomych oraz intensywnych relacjach społecznych, lecz także o randze i ważności roli społecznej pełnionej przez użytkownika aparatu telefonicznego.

Telefon komórkowy przestał być jedynie narzędziem łatwego i szybkiego komunikowania, obecnie wyznacza także status społeczny, określa stopień atrakcyjności

24 A. Pomieciński, Reklama w kulturze współczesnej. Studium antropologiczne, Wydawnictwo Poznańskie, Poznań 2005, s. 12.

25 Z. Melosik, Kultura instant paradoksy poptożsamości, [w:] M. Cylkowska-Nowak (red.), Edukacja. Społeczne konstruowanie idei i rzeczywistości, Wydawnictwo Wolumin, Poznań 2000, s. 372-385.

26 Z. Melosik, Kultura popularna jako czynnik socjalizacji, [w:] Z. Kwieciński, B. Śliwerski (red.), Pedagogika. Podręcznik akademicki, PWN, Warszawa 2004, T. 2, s. 69-70.

27 P. Levinson, Telefon komórkowy. Jak zmienił świat najbardziej mobilny ze środków komunikacji, Warszawskie Literackie Wydawnictwo MUZA SA, Warszawa 2006, s. 56. 
jego użytkownika, podlega zmianom w modzie i jest jednym z materialnych wyznaczników poziomu życia i społecznego prestiżu.

Wymienione czynniki w istotnym stopniu mają wpływ na nadmierne korzystanie z tego wielofunkcyjnego urządzenia i nie mogą zostać pominięte przy identyfikowaniu źródeł fonoholizmu, a tym bardziej w podejmowanych działaniach wychowawczych i profilaktycznych.

\section{Konsekwencje wynikające $\mathrm{z}$ fonoholizmu}

W przypadku fonoholizmu występują kompulsywne, przewlekłe, powtarzające się zachowania, które dystansują jednostkę od codziennych czynności związanych $\mathrm{z}$ aktywnością $\mathrm{w}$ podstawowych sferach funkcjonowania społecznego oraz stają się przyczyną negatywnych zdarzeń i uczuć. Kompulsywne zachowanie jest zazwyczaj bardzo trudne do zatrzymania i ostatecznie powoduje negatywne konsekwencje psychospołeczne i zdrowotne. Fonoholicy w sytuacjach, w których nie mogą skorzystać z telefonu lub zostają pozbawieni dostępu do niego, czują się źle, nie potrafią myśleć o niczym innym poza telefonem, są rozkojarzeni, trudno im się skupić na tym, co robią $^{28}$. Odczuwają głęboki dyskomfort (przejawiający się złym nastrojem, niepokojem, w pewnych przypadkach nawet atakami paniki).

Jak wynika $z$ raportu prezentującego wyniki ogólnopolskich badań przeprowadzonych wśród 22086 młodych osób między 12 a 18 rokiem życia przez 3471 nauczycieli oraz w ramach eksperymentu społecznego pt. „POZ@ SIECIĄ” i badań jakościowych prowadzonych w roku 2015-2016 $6^{29}$, część młodzieży wskazywała na różnego rodzaju skutki (jak: przemęczenie, obniżony nastrój, niewywiązywanie się z własnych obowiązków, drżenie rąk, agresja związana z niemożnością skorzystania z urządzenia i Internetu), które mogą świadczyć o kompulsywnym używaniu urządzeń mobilnych włączonych w sieć.

W konsekwencji uzależnienia fonoholicy stopniowo wycofują się z relacji ze światem rzeczywistym, spędzając wiele czasu samotnie, nie rozstając się ze swym telefonem (np. grając w gry, nieustannie wysyłając SMS-y, korzystając z sieci internetowej). Osoby takie rezygnują ze spotkań z przyjaciółmi, kina, spacerów, przeznaczając czas

${ }^{28}$ Zob.: C. Guerreschi, dz. cyt., s. 208.

${ }^{29}$ Raport „Nałogowe korzystanie z telefonów komórkowych. Szczegółowa charakterystyka zjawiska fonoholizmu w Polsce” został opracowany na podstawie wyników ogólnopolskich badań przeprowadzonych wśród 22086 młodych osób między 12 a 18 rokiem życia i 3471 nauczycieli oraz eksperymentu społecznego pt. „Poz@ Siecią” polegającym na dobrowolnym odłączeniu 100 młodych osób na 3 pełne doby od telefonu komórkowego, Internetu, tabletów/komputerów, telewizji, gier on-line i typu playstation. Zob. szerzej: M. Dębski, Nałogowe korzystanie z telefonów komórkowych. Szczegółowa charakterystyka zjawiska fonoholizmu w Polsce. Raport z badań, Gdynia 2016, s. 30, http://www.cen.gda.pl/wp-content/uploads/2017/02/Nalogowe-korzystanie-Z-telefonow-komorkowych.-RAPORT-Z-BADAN.pdf (dostęp: 27.06.2017). 
na wzmożone korzystanie $\mathrm{z}$ telefonu ${ }^{30}$, co prowadzić może do mentalnego oderwania się od otaczającej rzeczywistości. Nadmierne korzystanie z telefonu komórkowego może jednocześnie zaburzać komunikację o charakterze spontanicznym i pierwotnym, zastępując go spreparowaną formą zastępczą o pozorach oryginalności, prowadzącą do utraty autentyczności w relacjach interpersonalnych.

Ponadto brak kontaktu ze źródłem uzależnienia (telefonem komórkowym) prowadzić może do wystąpienia zespołu objawów - „syndromu odstawienia” zwanego też „syndromem abstynencji”, który najczęściej charakteryzuje się: gwałtownymi wahaniami nastroju, stanami depresyjnymi, specyficznym dyskomfortem psychosomatycznym, zaburzeniami trawiennymi (np. brakiem łaknienia), poczuciem zmęczenia oraz wyczerpaniem i osłabieniem organizmu (bólami i zawrotami głowy, mięsni, stawów, nudnościami, zaburzeniami widzenia) ${ }^{31}$.

Konsekwencją nadmiernego korzystania z telefonu komórkowego mogą być problemy fizyczne, m.in. takie jak pogorszenie wzroku i słuchu oraz zaburzenia równowagi ${ }^{32}$. W przypadku fonoholizmu pojawić się mogą również inne objawy, takie jak np. wystąpienie bezsenności w nocy z następczą sennością w ciągu dnia, a nawet lęk przed zaśnięciem spowodowany potrzebą ciągłego kontaktu z aparatem telefonicznym (np. budzenie się w nocy w celu czytania SMS-ów) ${ }^{33}$. Należy także podkreślić, że nieustanne wysyłanie wiadomości tekstowych może stać się przyczyną niedokrwienia kciuka oraz ogólnego pogarszania stanu zdrowia (zaburzenie rytmu dobowego, zmęczenie organizmu, systemu odpornościowego organizmu itp. $)^{34}$.

W przypadku fonoholizmu szczególnie interesujące zjawisko stanowi personifikacja urządzenia mobilnego, jakim jest telefon komórkowy. Na problem zwraca między innymi uwagę Cesare Guerreschi, podkreślając, że

więź łącząca użytkownika z aparatem komórkowym wykracza poza zainteresowanie zwykłym urządzeniem technicznym i chęć doświadczania przyjemności z jego użytkowania. Stosunek do telefonu przekształca się w coś, co przypomina związek emocjonalny ${ }^{35}$.

Problem ten występuje także wśród tych uczniów, których objęto ogólnopolskimi badaniami i eksperymentem społecznym „POZ@ SIECIĄ”. Nietórzy sygnalizowali,

${ }^{30}$ T. Szlendak, Wielkie Halo, „Charaktery”, nr 5(124)/2007, s. 34-35; D Sarzała, Interholizm (uzależnienie od Internetu, [w:] Z. Kosyrz (red.), Człowiek w sieci zniewolonych dróg, Pedagogium, WSPR w Warszawie, Warszawa 2009, s. 127-133.

31 A. Jakubik, Zespót uzależnienia od Internetu (ZUI) - Internet Addiction Syndrome (IAS), http://www.psychologia.net.pl/artykul.php?level=52 (dostęp: 27.06.2017); M. Orzack, Computer addiction services, http://www.computeraddiction.com (dostęp: 30.06.2017).

${ }^{32}$ Ch. Park and Y. R. Park, dz. cyt., s. 149.

${ }^{33}$ C. Guerreschi, dz. cyt., s. 207.

${ }^{34}$ K. Kaliszewska, Z@gubieni w sieci, [w:] L. Cierpiałkowska (red.), Oblicza współczesnych uzależnień, Poznań 2006, s. 111;. M. Orzack, dz, cyt.; A. Jakubik, Zespół uzależnienia od Internetu, „Studia Psychologica UKSW", nr 3/2002, s. 133-144, 142.

${ }^{35}$ C. Guerreschi, dz. cyt., s. 22. 
że odczuwają emocje w stosunku do czynności wykonywanych za pośrednictwem telefonów komórkowych i cierpią po stracie tych urządzeń ${ }^{36}$. Jak wynika $z$ raportu, młodzi respondenci zaprzeczali wprawdzie, gdy pytano ich wprost o obdarzanie urządzeń jakimikolwiek uczuciami i nadawanie im tożsamości istot żywych, jednak przy charakteryzowaniu swoich telefonów używali określeń takich jak: sprytny, inteligentny, przebiegły, „kobiecy smart”, odnoszonych zwykle jedynie do ludzi (ewentualnie zwierząt $)^{37}$. Młodzi respondenci stwierdzali także, że życie bez urządzeń mobilnych jest niemal niemożliwe, a posiadanie tychże stanowi dla nich przedmiot dążeń i pragnień (np. rezygnują z kieszonkowego na rzecz zakupu nowego modelu smartfona) ${ }^{38}$.

Należy również stwierdzić, że fonoholizm wywiera negatywny wpływ na naukę szkolną. Z badań, które przeprowadził Ozlem Cagan, wynika, że istnieje negatywna korelacja między uzależnieniem od telefonu komórkowego a sukcesem w nauce ${ }^{39}$. Do podobnego wniosku można dojść, analizując wyniki ogólnopolskich badań, prezentowane w cytowanym wcześniej raporcie. Wynika z nich, że szczególnie niepokojącymi skutkami fonoholizmu wśród młodzieży szkolnej są problemy z mową, nauką i koncentracją oraz spadek aktywności szkolnej i pozaszkolnej ${ }^{40}$.

\section{Środowisko rodzinne i szkolne a problem fonoholizmu}

Potencjalne zagrożenia, na jakie narażeni są użytkownicy telefonii komórkowej w razie wystąpienia uzależnienia, wskazują na konieczność podejmowania działań mających na celu zapobiegania zjawisku fonoholizmu. Należy przede wszystkim wyposażać dzieci i młodzież w umiejętności samodzielnego ograniczania czasu korzystania $\mathrm{z}$ telefonu komórkowego. Istotne jest by uczyć dokonywania wyboru w zetknięciu z różnymi formami aktywności, jakie mogą być realizowane za pośrednictwem telefonu komórkowego, oraz obiektywnej i krytycznej oceny ich wartości. W procesie wychowania i edukacji szczególnie ważne staje się przygotowanie dziecka do korzystania z zasobów cyberprzestrzeni, w tym telefonu komórkowego, w zależności od aktualnych potrzeb, a zwłaszcza kształtowanie postaw oraz umiejętności i nawyków w zakresie właściwego i odpowiedzialnego używania tych urządzeń. W dobie dynamicznie rozwijających się mediów elektronicznych zadania te są jednymi z najważniejszych, jakie stoją nie tylko przed rodziną i szkołą, lecz także przed innymi podmiotami uczestniczącymi w procesie wychowania.

Wielu rodziców nie jest w stanie zapewnić swym dzieciom odpowiedniej pomocy, ponieważ nie posiadają w tym zakresie ani wystarczających umiejętności, ani nie

\footnotetext{
36 M. Dębski, dz. cyt., s. 26.

37 Tamże, s. 26.

38 Tamże, s. 26-28.

39 O. Cagan, A. Unsal, N. Celik, dz. cyt., s. 831-839.

${ }^{40}$ M. Dębski, dz. cyt., s. 26.
} 
znają specyfiki zagrożeń związanych z korzystaniem z nowych multimediów elektronicznych. Z badań zjawiska fonoholizmu w Polsce ${ }^{41}$ wynika, że rola rodziców sprowadza się najczęściej do zakupu telefonu komórkowego i regulowania rachunków za jego użytkowanie, a motywem do podjęcia takich działań jest zarówno potrzeba bycia w stałym kontakcie z dzieckiem, jak i możliwość ciągłej kontroli miejsca jego przebywania. Dotyczy to nie tylko dzieci w młodszym wieku szkolnym lub gimnazjalistów, lecz także uczniów szkół ponadgimnazjalnych. Ponadto stwierdzono, że wielu rodziców komunikuje się ze swoimi dziećmi za pośrednictwem telefonu komórkowego (SMS-y, portale społecznościowe) nawet podczas wspólnego przebywania w domu. W pewnym więc stopniu nadmierne korzystanie z telefonów komórkowych przez dzieci i młodzież szkolną może wynikać $\mathrm{z}$ chęci rodziców do pozostawania w ciągłym kontakcie z dzieckiem. Niepokoi również fakt, że ponad połowa rodziców nie rozmawia z dziećmi na tematy dotyczące zagrożeń, jakie są związane z nadmiernym i niekontrolowanym korzystaniem z telefonu komórkowego, smartfona i sieci internetowej. Należy jednocześnie podkreślić, że uczniowie, których rodzice nie ustanowili żadnych zasad dotyczących korzystania z telefonów komórkowych oraz nie rozmawiają z nimi na temat szkodliwości niekontrolowanego korzystania $\mathrm{z}$ tych urządzeń, osiągnęli statystycznie znacząco wyższe wyniki w ogólnej skali fonoholizmu².

Zaznaczmy również, że duża część samych rodziców dotknięta jest różnego rodzaju formami cyberuzależnienia (np. uzależnieniem od telewizji, telefonu komórkowego, Internetu). Należy bowiem pamiętać, że problem nadmiernego, niekontrolowanego korzystania z urządzeń mobilnych dotyczy nie tylko dzieci i młodzieży, lecz także osób dorosłych, wśród których określony odsetek niewątpliwe stanowią rodzice. Wielu z nich nie tylko bardzo aktywnie korzysta $\mathrm{z}$ telefonu komórkowego, różnego rodzaju portali społecznościowych (m.in. Facebooka), ale też angażuje się w gry komputerowe czy też stanowi np. wielomilionową widownię licznych, wprost niekończących się, emisji seriali telewizyjnych. Zachodzi zatem potrzeba edukowania rodziców, mającego na celu udzielenie im pomocy w podnoszeniu umiejętności komunikacyjnych z dziećmi w zakresie tematyki dotyczącej zagrożeń związanych z używaniem telefonu komórkowego ${ }^{43}$. Rodziny odgrywają bowiem ważną rolę w zapobieganiu uzależnieniom i nie mogą być pomijane przy opracowywaniu programów profilaktycznych i terapeutycznych w tym zakresie ${ }^{44}$.

41 Tamże, s. 33 .

42 Tamże, s. 33.

${ }^{43}$ J. Y. Yen, C. F. Yen, C. C. Chen, S. H. Chen, C. H. Ko, Family factors of internet addiction and substance use experience in Taiwanese adolescents, „Cyberpsychology \& Behavior”, nr 10(3)/2007, s. 323-329.

${ }^{44}$ S. K. Park, J. Y. Kim, C. B. Cho, Prevalence of Internet addiction and correlations with family factors among South Korean adolescents, „Adolescence”, nr 43(172)/2008, s. 895-909; J. Matejek, M. Z. Jędrzejko, M. Kowalczyk-Marcjan, Rodzina jako podstawowy czynnik ochronny przed zachowaniami ryzykownymi, [w:] M. Z. Jędrzejko, R. Sieroń (red.), Raport z badań, zachowania ryzykowne nastolatków - Nowa jakość ryzyka - ryzyka wielowymiarowe. Ujęcie socjopedagogiczne, Oficyna 
Specjalistyczne wsparcie potrzebne jest jednak nie tylko rodzicom, lecz również nauczycielom, którzy w wielu przypadkach są osamotnieni i bezradni wobec problemu cyberuzależnień. Przeprowadzone badania wskazują, że większość szkół nie jest w pełni przygotowana do przeciwdziałania zjawisku fonoholizmu. Nauczyciele, mimo że dostrzegają wysokie natężenie tego problemu na przestrzeni ostatnich lat, stwierdzają, że nie posiadają wystarczających kompetencji niezbędnych do prowadzenia zajęć profilaktycznych z uczniami w tym zakresie ${ }^{45}$. Potrzebne są zwłaszcza szkolne programy profilaktyczne, ukierunkowane na kształtowanie umiejętności i właściwych postaw w zakresie odpowiedzialnego korzystania z urządzeń mobilnych posiadających dostęp do sieci internetowej.

\section{Konkluzje}

Na podstawie przeprowadzonej analizy możemy stwierdzić, że nadmierne korzystanie z telefonu komórkowego stwarza ryzyko uzależnienia niesubstancjalnego, określanego jako uzależnienie behawioralne, w wyniku którego dana osoba zmuszona jest do podejmowania czynności lub wchodzenia w relację z przedmiotem uzależnienia.

Z uwagi na negatywne konsekwencje fonoholizmu, ujawniające się w sferze psychospołecznej i fizycznej, zaburzające prawidłowe funkcjonowanie i rozwój człowieka, należy to zjawisko zaliczyć do szerokiego spektrum zachowań ryzykownych młodzieży szkolnej.

W celu przeciwdziałania fonoholizmowi niezbędne jest zarówno prowadzenie odpowiednich działań wychowawczych i edukacyjnych wśród dzieci i młodzieży, jak i uświadamianie oraz uwrażliwianie rodziców oraz nauczycieli w zakresie problematyki dotyczącej zagrożeń związanych z korzystaniem z telefonu komórkowego i innych urządzeń mobilnych. Uczniów, którzy z uwagi na określone cechy osobowości są szczególnie narażeni na ryzyko cyberuzależnienia, należy objąć właściwym wsparciem psychologicznym.

Podkreślmy jednocześnie, że określenie limitu czasowego lub wzorca zachowania czy też granicy, za pomocą której można oddzielić prawidłowe korzystanie z telefonu od nadmiernego, jest trudne. Zachodzi więc potrzeba pogłębionej refleksji naukowej, której głównym celem powinno być wskazanie granicy pomiędzy bezpiecznym a wykraczającym poza normę użytkowaniem urządzeń mobilnych (w tym telefonu komórkowego), a także wyodrębnienie kryteriów diagnostycznych, umożliwiających rozpoznanie fonoholizmu i innych form cyberuzależnienia, w celu skutecznego zapobiegania tym zjawiskom.

Wydawnicza ASPRA JR, Warszawa - Milanówek 2016, s. 113; E. Gałązka, Jak zapobiegać fonoholizmowi?, ,Wychowawca”, nr 2/2016, s. 22.

${ }^{45}$ M. Dębski, dz. cyt., s. 36. 


\section{Bibliografia}

Augustynek A., Uzależnienia komputerowe. Diagnoza, rozpowszechnienie, terapia, Difin, Poznań 2010.

Baranowska A., Fonoholizm wśród uczniów, „Wychowawca”, nr 2/2016, s. 20-21.

Barłóg M. J., Uzależnienie od Internetu i jego osobowościowe determinanty, „Hygeia Public Health", nr 50(1)/2015, s. 197-202.

Billieux J., Problematic Use of the Mobile Phone: A Literature Review and a Pathways Mode, „Current Psychiatry Reviews”, nr 4/2012, s. 1-9.

Brezinka W., Wychowywać dzisiaj: zarys problematyki, Wydawnictwo WAM, Kraków 2007.

Cagan O., Unsal A., Celik N., Evaluation of college students the level of Addiction to Cellular Phone and Investigation on the Relationship between the Addiction and the Level of Depression, „Procedia - Social and Behavioral Sciences”, nr 114(21)/2014, s. 831-839.

Children's use ofmobilephones-Aninternational comparison 2012, GSMAssociation and the Mobile Society Research Institute within NTT DOCOMO Inc., Japan 2013, https://www.gsma.com/publicpolicy/wp-content/uploads/2012/03/GSMA ChildrensMobilePhones2012WEB.pdf (dostęp: 29.06,2017);

Chóliz M., Mobile phone addiction: a point of issue, „Addiction”, nr 105(2)/2010, s. 373-374.

Cierpiałkowska L., Kierunki rozwoju współczesnej psychologii uzależnień, [w:] L. Cierpiałkowska (red.), Oblicza współczesnych uzależnień, UAM, Poznań 2006, s. 17-41.

Dębski M., Nałogowe korzystanie z telefonów komórkowych. Szczegółowa charakterystyka zjawiska fonoholizmu w Polsce. Raport z badań, Gdynia 2016, http:// www.cen.gda.pl/wp-content/uploads/2017/02/Nalogowe-korzystanie-z-telefonow-komorkowych.-RAPORT-Z-BADAN.pdf (dostęp: 27.06.2017).

Dowling N. A., Brown M., Commonalities in the psychological factors associated with problem gambling and Internet dependence, in Cyberpsychology, „Behavior, and Social Networking", nr 4(13)/2010, s. 437-441.

Egger O., Rauterberg M., Internet behavior and addiction; http://www.idemployee. id.tue.nl/g.w.m.rauterberg/ibq/report.pdf (dostęp: 29.06.2017) .

Farago P. iOS and Android Adoption Explodes Internationally 2012, http://blog.flurry.com/bid/88867/iOS-and-Android-Adoption-Explodes-Internationally (dostęp: 29.06.2017).

Figurska M., Haloooo... tu fonoholik, „Charaktery”, nr 4/2012, s. 82-85.

Gałązka E., Jak zapobiegać fonoholizmowi?, „Wychowawca”, nr 2/2016, s. 22.

Griiffths M., Gry i hazard. Uzależnienia dzieci w okresie dorastania, GWP, Gdańsk 2004.

Grunbaum J. A., Kann L., Kinchen S., Ross J., Hawkins J., Lowry R., Harris W. A., McManus T., Chyen D., Collins J., Youth Risk Behavior Surveillance-United States, 2003, „MMWR Surveill Summary”, nr 53(2)/2004, s. 1-96. 
Guerreschi C., Nowe uzależnienia, Wydawnictwo Salwator, Kraków 2005, s. 197-198. Guzowska E., Zagrożenia wynikające z korzystania z telefonów komórkowych, „Problemy Opiekuńczo-Wychowawcze", nr 7/2015, s. 46-50.

Irwin Ch. E., The Theoretical Concept of At-Risk Adolescents, „Adolescent Medicine: State of the Art Reviews", nr 1/1990, s. 1-14.

Jakubik A., Zespół uzależnienia od Internetu (ZUI) - Internet Addiction Syndrome (IAS), http://www.psychologia.net.pl/artykul.php?level=52 (dostęp: 27.06.2017).

Jakubik A., Zespół uzależnienia od Internetu, „Studia Psychologica”, nr 3/2002, s. 133-144.

Jessor R., New perspectives on adolescent risk behavior, Cambridge University Press, New York 1998.

Jędrzejko M. Z., „Zawirowany” świat ponowoczesności. „Swirly” World of Postmodernity, Wydawnictwo Aspra JR, Warszawa - Milanówek 2015.

Jędrzejko M. Z., Sarzała D., Taper A., Szwedzik A., Nowe przestrzenie i modele ryzyka, [w:] M. Z. Jędrzejko, R. Sieroń (red.), Raport z badań, zachowania ryzykowne nastolatków - Nowa jakość ryzyka - ryzyka wielowymiarowe. Ujęcie socjopedagogiczne, Wydawnictwo Aspra JR, Warszawa - Milanówek 2016, s. 117-138.

Kaliszewska K., Z@gubieni w sieci, [w:] L. Cierpiałkowska (red.), Oblicza współczesnych uzależnień, UAM, Poznań 2006, s. 107-119.

Kozak S., Patologia fonoholizmu przyczyny, skutki i leczenie uzależnienia dzieci i młodzieży od telefonu komórkowego, Difin SA, Warszawa 2013.

Lacohèe H., Wakeford N., Person I., A Social History of the Mobile Telephone with a View of its Future, „BT Technology Journal”, nr 21(3)/2003, s. 203-211.

Lenihan F., Computer addiction - a sceptical view Invited commentary on: Lost online, „Advances in Psychiatric Treatment”, nr 13(1)/2006, s. 31-33.

Levinson P., Telefon komórkowy. Jak zmienił świat najbardziej mobilny ze środków komunikacji, Warszawskie Literackie Wydawnictwo MUZA SA, Warszawa 2006.

Matejek J., Jędrzejko M. Z., Kowalczyk-Marcjan M., Rodzina jako podstawowy czynnik ochronny przed zachowaniami ryzykownymi, [w:] M. Z. Jędrzejko, R. Sieroń (red.), Raport z badań, zachowania ryzykowne nastolatków - Nowa jakość ryzyka - ryzyka wielowymiarowe. Ujęcie socjopedagogiczne, Oficyna Wydawnicza Aspra JR, Warszawa - Milanówek 2016, s. 113-126.

Melosik Z., Kultura instant paradoksy pop-tożsamości, [w:] M. Cylkowska-Nowak (red.), Edukacja. Społeczne konstruowanie idei i rzeczywistości, Wydawnictwo Wolumin, Poznań 2000, s. 372-385.

Melosik Z., Kultura popularna jako czynnik socjalizacji, [w:] Z. Kwieciński, B. Śliwerski (red.), Pedagogika. Podręcznik akademicki, PWN, Warszawa 2004, T. 2, s. 68-93.

Mysior R., Fonoholizm - w kręgu uzależnienia, „Problemy Opiekuńczo-Wychowawcze”, nr 10/2015, s. 28-33.

Orzack M., Computer addiction services, http://www.computeraddiction.com (dostęp: 30.06.2017) 
Park Ch., Park Y. R., The Conceptual Model on Smart Phone Addiction among Early Childhood, „International Journal of Social Science and Humanity”, nr 2(4)/2014, s. 147-150.

Park S. K., Kim J. Y., Cho C. B., Prevalence of Internet addiction and correlations with $\mathrm{fa-}$ mily factors among South Korean adolescents, ,Adolescence”, nr 43(172)/2008, s. 895-909.

Pedrero Pérez E. J., Rodríguez Monje M. T., Ruiz Sánchez De León J. M., Mobile phone abuse or addiction. A review of the literature, „Adicciones”, nr 24(2)/2012, s. 139-152.

Peters O., Allouch S. B., Zawsze w kontakcie: badanie podłużne pola komunikacji mobilnej, ,Polityka Telekomunikacja” 2005, T. 22, s. 239-256.

Pomieciński A., Reklama w kulturze współczesnej. Studium antropologiczne, Wydawnictwo Poznańskie, Poznań 2005.

Sarzała D., Interholizm (uzależnienie od Internetu), [w:] Z. Kosyrz (red.), Człowiek $w$ sieci zniewolonych dróg, Pedagogium, WSPR w Warszawie, Warszawa 2009, s. $127-133$.

Sarzała D., Cyberprzestrzeń a problem uzależnień, [w:] E. Łuczak (red.), Nowe oblicza uzależnień, UWM, Olsztyn 2009, s. 135-150

Sarzała D., Telefon komórkowy jako nowe źródło zagrożeń, [w:] M. Jędrzejko, D. Sarzała (red.), Człowiek i zagrożenia, Pułtusk 2010, s. 219-238.

Sarzała D., Wartości a społeczne funkcjonowanie człowieka, [w:] E. Jarmoch, A. W. Świderski, I. A. Trzpil (red.), Bezpieczeństwo człowieka a wartości, T. 1: Aspekty filozoficzne i edukacyjne, Wydawnictwo Akademii Podlaskiej, Siedlce 2010, s. 187-205.

Strategy Analytics, Worldwide Smartphone Population Tops 1 Billion in Q3 2012. Wireless Smartphone Strategies 2012, http://blogs.strategyanalytics.com/ WDS/post/2012/10/17/Worldwide-Smartphone-Population-Tops-1-Billion-in-Q3-2012.aspx (dostęp: 14.07.2017)

Suler J., Therapy and Support Groups, http://users.rider.edu/ suler/psycyber/ (dostęp: 29.06.2017).

Szlendak T., Wielkie Halo, „Charaktery”, nr 5(124)/2007, s. 34-35.

Thomée S., Harenstam A., Hagberg M., Mobile phone use and stress, sleep disturbances, and symptoms of depression among young adults: a prospective cohort study, „BMC Public Health”, nr 11(66)/2011, https://doi.org/10.1186/1471-2458-11$\underline{66}$ (dostęp: 09.11.2017).

Tossell Ch., Kortum P., Shepard C., Zhong L., Exploring Smartphone Addiction: Insights from Long-Term Telemetric Behavioral Measures, „iJIM”, nr 9/2015, s. $37-43$.

Tsitsika A., Tzavela E. F., Mavromati and the EU NET ADB Consortium, Research on Internet addictive behaviours among European adolescents, (2012), www.eunetadb.eu (dostęp: 28.06.2017) 
Wiaderek W., Gdy brak zasięgu, „Problemy Opiekuńczo-Wychowawcze”, nr 7/2012, s. $49-50$.

Yang C. Y., Sato T., Yamawaki N., Miyata M., Prevalence and risk factors of problematic Internet use: A cross-national comparison of Japanese and Chinese university students, „Transcultural Psychiatry”, nr 50(2)/2013, s. 263-79.

Yen C. F., Chen C. C., Chen S. H., Ko C. H., Family factors of internet addiction and substance use experience in Taiwanese adolescents, „Cyberpsychology \& Behavior", $\mathrm{nr}$ 10(3)/2007, s. 323-329.

Young K., Internet addiction over the decade: A personal look back, „World Psychiatry”, nr 9(2)91/2010, https://www.ncbi.nlm.nih.gov/pmc/articles/PMC2911082/ (dostęp: 10.11.2017).

Young K., Internet addiction: The emergence of a new clinical disorder, „Cyberpsychology \& Behavior", nr 3/1996, s. 237-244.

\section{Phonoholism among school youth as a new form of risky behavior}

Abstract: The article presents the phenomenon of excessive use of mobile phones, that takes the form of a new cyber addiction, termed phonyholism.. The author focused primarily on the problem of the possibility of becoming addicted to this device. He presented symptoms of phonoholism and negative consequences for the health and psychosocial development of school youth in the context of risky behavior. It also emphasized the need to distinguish diagnostic criteria from phonoholism. In the article the author also pointed out the role of family and school in counteracting this phenomenon.

Keywords: cyberspace, cyber addiction, phonoholism, excessive use of mobile phone, mobile phone addiction, school youth, risky behavior

About the author: Dariusz Sarzała - pedagogue and philosopher, doctor of humanities. Assistant Professor at the Department of Pedagogy of Resocialization at the Faculty of Social Sciences at the University of Warmia and Mazury in Olsztyn. His research interests focus on the issue of social maladjustment and social reintegration. He also explores behavioral addictions and new deviant phenomena occurring in cyberspace and their determinants. Author, co-author and co-editor of more than 120 scientific articles and books covering thematic areas mentioned before, published in Poland and abroad. 


\author{
Janina Florczykiewicz* \\ Uniwersytet Przyrodniczo-Humanistyczny w Siedlcach \\ janinaflorczykiewicz@poczta.fm
}

\title{
Implementacje teoretycznych założeń wychowania estetycznego w pozainstytucjonalnej edukacji plastycznej w latach 80. XX wieku na przykładzie działalności grupy pARTner ${ }^{1}$
}

\begin{abstract}
Streszczenie: W tekście zaprezentowano ideę nowatorskich działań z zakresu edukacji plastycznej, rozwijanych w latach 80. przez członków grupy pARTner. Proponowane przez nich działania, respektując postulaty rozwijanych wówczas w Polsce koncepcji wyrosłych na gruncie wychowania estetycznego, znacznie wykraczały poza instytucjonalne formy zajęć plastycznych. Różnice dotyczyły również stawianych im celów i poglądów na rolę procesu twórczego w edukacji. Poprzedzająca te rozważania analiza statusu sztuki we współczesnej teorii wychowania tworzy teoretyczny kontekst dla prezentowanego zagadnienia.
\end{abstract}

Słowa kluczowe: wychowanie estetyczne, praktyka edukacji plastycznej, grupa pARTner, nowatorskie metody edukacji plastycznej

Przyjmując współczesne rozumienie edukacji jako ogółu oddziaływań służących formowaniu się zdolności życiowych człowieka², należy definiować ją jako proces skierowany na rozwój podmiotowy. Obejmuje on procesy kształcenia i samokształcenia związane z nabywaniem wiedzy i kompetencji oraz wychowania. $\mathrm{W}$ tej perspek-

* Dr hab. Janina Florczykiewicz - pedagog, profesor nadzwyczajny na Wydziale Humanistycznym Uniwersytetu Przyrodniczo-Humanistycznego w Siedlcach.

${ }^{1}$ Wyniki prezentowanych w niniejszym tekście badań zostały opracowane w ramach tematu badawczego $\mathrm{nr} / 381 / 14 / \mathrm{S}$ i zostały sfinansowane $\mathrm{z}$ dotacji na naukę przyznanej przez Ministerstwo Nauki i Szkolnictwa Wyższego.

${ }^{2}$ Zob.: B. Milerski, B. Śliwerski, Pedagogika (Leksykon PWN), Warszawa 2000, s. 54. 
tywie szeroko rozumianą edukację plastyczną ${ }^{3}$ można traktować dwojako: 1) jako zespół działań edukacyjnych, w tym również autoedukacyjnych, skoncentrowanych na realizacji postulatu rozwoju osobowego w oparciu o mechanizmy i środki wyrazu z obszaru sztuk wizualnych, albo 2) jako działania edukacyjne skoncentrowane na kształceniu kompetencji warsztatowych przygotowujących do samodzielnej pracy twórczej lub/i uprawiania zawodu albo wykonywania działalności usługowej wymagających umiejętności warsztatowych z zakresu plastyki. Druga z podanych definicji funkcjonuje w szkolnictwie artystycznym, w którym priorytetowe staje się kształcenie umiejętności warsztatowych, $\mathrm{z}$ kolei dla podjętego w tym opracowaniu zagadnienia nowatorskich propozycji z zakresu edukacji plastycznej odpowiednie będzie ujęcie pierwsze, które odnosi się bezpośrednio do wspomnianego wyżej formowania zdolności życiowych, obejmującego wszystkie obszary funkcjonowania człowieka, tj. intelektualny, emocjonalny, motywacyjny, fizyczny i społeczny.

Edukacja, przynależąc do sfery praktyki, odwołuje się do ustaleń teoretycznych wypracowanych w obszarze pedagogiki, natomiast koncepcje edukacji plastycznej są formułowane w nawiązaniu do koncepcji wychowania estetycznego, wykraczającej poza ramy pedagogiki. Owo zanurzenie edukacji plastycznej w estetyce każe poszukiwać jej źródeł również na gruncie tej dyscypliny, dlatego w pierwszej kolejności podjęto rozważania nad statusem sztuki we współczesnej teorii wychowania estetycznego.

\section{Status sztuki we współczesnej teorii wychowania estetycznego}

Teoria wychowania estetycznego jest rozwijana na gruncie dwóch dyscyplin estetyki i pedagogiki. W początkach swojego rozwoju wychowanie estetyczne traktowane było jako odrębna dziedzina wychowania, wykorzystująca metody i środki z zakresu sztuki w realizacji ogólnego celu wychowania, jakim jest rozwój osobowości podopiecznego. Owo ograniczenie rozważań do jednej dyscypliny powodowało znaczne zawężenie ich przedmiotu, dlatego pojawił się postulat integracji wychowania estetycznego, tj. włączenia go w zakres holistycznie ujętego modelu wychowania ten sposób myślenia odnajdujemy między innymi w poglądach Bogdana Suchodolskiego czy Ireny Wojnar.

Dla teorii wychowania estetycznego kluczowym pojęciem jest sztuka. Jej prymarna właściwość określana jest przez wartość estetyczną i zdolność do inicjowania

\footnotetext{
${ }^{3}$ Termin „edukacja plastyczna” odnosi się w tym tekście do edukacji pojmowanej jako proces nauczania/uczenia się, i jego organizacji na każdym szczeblu edukacji instytucjonalnej i pozainstytucjonalnej. Należy wspomnieć, że terminologia używana w literaturze jest niejednolita, często autorzy posługują się terminem „wychowanie plastyczne”, który jest odnoszony zarówno do teoretycznej koncepcji nauczania w zakresie sztuk plastycznych, jak i występował jako nazwa przedmiotu szkolnego i nazwa kierunku studiów. Obecnie termin zbliżony do proponowanego tj. „edukacja artystyczna w zakresie sztuk plastycznych" stanowi nazwę kierunków studiów.
} 
przeżyć estetycznych, stąd koncepcje wychowania estetycznego zakładają kształcenie kultury estetycznej i stosunku do wartości estetycznych ${ }^{4}$. Kultura estetyczna jest wyznaczana przez kompetencje podmiotu w zakresie rozumienia i przeżywania sztuki oraz zdolność do dostrzegania wartości estetycznych w otoczeniu ${ }^{5}$. Z kolei wartość estetyczna, pierwotnie utożsamiana z pięknem, współcześnie ujmowana jest jako „szczególna własność”, odpowiedzialna za wywoływanie przeżyć estetycznych ${ }^{6}$. Zakłada się, że istnieje ona obiektywnie w pewnych przedmiotach - jest „zastana” przez odbiorcę niezależnie od jego woli czy świadomości. W naturze istnieje autonomicznie, w sztuce zaś zostaje powołana w akcie kreacji artystycznej. Ma charakter intersubiektywny, co oznacza jej zmysłową dostępność dla każdego człowieka wrażliwego na piękno ${ }^{7}$.

Na gruncie teorii wychowania estetycznego sztukę rozpatruje się przez pryzmat jej funkcji wychowawczej, wskazując na możliwości kształtowania za jej pośrednictwem postaw moralnych oraz budowania wewnętrznej harmonii za pośrednictwem wywoływanych w jej przestrzeni przeżyć estetycznych. Herbert Read zakłada, że rozwój moralny, w którym pośredniczy sztuka, dokonuje się poprzez przyswajanie wzorców moralnego postępowania zawartych w dziełach ${ }^{8}$, natomiast uzyskanie wewnętrznej harmonii łączy z integracją poznania intelektualnego i zmysłowego oraz aktywizacją dyspozycji twórczych, które dokonują się w przestrzeni sztuki ${ }^{9}$.

Zatem tradycyjne koncepcje wychowania estetycznego postulują kształcenie kultury estetycznej obejmujące kształtowanie postawy estetycznej oraz uprzystępnianie sztuki rozumiane jako wytwarzanie zainteresowania i zapotrzebowania na nią oraz rozwijanie zdolności właściwego jej postrzegania, rozumienia i przeżywania ${ }^{10}$. Nieco inaczej widziana jest rola sztuki we współczesnych koncepcjach wychowania estetycznego. W wielu z nich kładzie się akcent na rozwój osobowości, wiążąc go z aktywizacją kreatywności $\mathrm{w}$ działaniach podejmowanych $\mathrm{w}$ obszarze sztuki ${ }^{11}$. Pogląd o aktywizowaniu dyspozycji twórczych w sztuce był prezentowany już przez Stefana Szumana ${ }^{12}$, który wskazywał na poznawczą rolę artystycznych doświadczeń twór-

${ }^{4}$ I. Wojnar, Teoria wychowania estetycznego - zarys problematyki, Warszawa 1976, s. 232.; J. Mortkowiczowa, Estetyka wychowania, [w:] Teoria wychowania estetycznego. Wybór tekstów, Warszawa 1997, s. 38-39; B. Nawroczyński, O wychowaniu estetycznym, [w:] Teoria wychowania estetycznego. Wybór tekstów, Warszawa 1997, s. 112-128.

${ }_{5}$ Zob.: M. Gołaszewska, Kultura estetyczna, [w:] Teoria wychowania estetycznego. Wybór tekstów, Warszawa 1997, s. 349-351.

${ }^{6}$ Zob.: Taż, Zarys estetyki, Warszawa 1984, s. 143-145.

7 Tamże.

${ }^{8}$ Zob.: H. Read, Wychowanie przez sztukę, Zakład Narodowy im. Ossolińskich, Wrocław 1976.

9 Zob.: I. Wojnar, Perspektywy wychowawcze sztuki, Warszawa 1966, s. 223-224.

${ }^{10}$ S. Szuman, Sztuka wzbogaca i pogłębia człowieka, [w:] Teoria wychowania estetycznego. Wybór..., s. 137.

${ }^{11}$ Zob.: M. Gołaszewska, Zarys estetyki, Warszawa 1984; I. Wojnar, Teoria wychowania estetycznego...; S. Szuman, O sztuce i wychowaniu estetycznym, Warszawa 1969.

12 Zob.: S. Szuman, dz. cyt. 
czych (ekspresji plastycznej, muzycznej, literackiej) - ich skuteczność w uprzystępnianiu sztuki autor wiązał z podmiotowym doświadczeniem kreacji poszerzającym rozumienie sztuki. Również Bogdan Nawroczyński ${ }^{13}$ pisał o wychowawczym znaczeniu tzw. wytwórczych czynności estetycznych, które wiązał zarówno z kształtującą ekspresją estetyczną, tzn. taką, która jest udziałem artystów i prowadzi do powstania dzieła sztuki, jak i naiwną twórczością ${ }^{14}$ uprawianą przez dzieci, młodzież i dorosłych niebędących artystami ${ }^{15}$.

Kluczowy dla koncepcji wychowania przez sztukę (rozwijanej w Polsce przez Bogdana Suchodolskiego w ramach wychowania estetycznego) był postulat rozwoju osobowości za jej pośrednictwem. Koncepcja ta, choć inspirowana myślą Herberta Reada, została zbudowana na odmiennych założeniach teoretycznych. Jej cechą jest przesunięcie koncentracji z wychowawczych aspektów sztuki na działania pedagogiczne, ukierunkowane na uwrażliwienie wychowanków na sztukę i kształtowanie w nich kompetencji pełnego jej odbioru, pozwalającego na doświadczanie zawartej w niej wartości ${ }^{16}$. Suchodolski traktuje teorię wychowania estetycznego jako część teorii pedagogiki ogólnej, postulując tym samym integrację oddziaływań wychowawczych $^{17}$. Wskazuje na wąskie i szerokie rozumienie wychowania estetycznego. W ujęciu węższym sprowadza je do kształcenia kultury estetycznej, wprowadzając na jego oznaczenie termin „wychowanie do sztuki”. Wychowanie estetyczne w szerokim ujęciu określa jako „wychowanie przez sztukę”, włączając w jego zakres aktywność artystyczną (tworzenie) i odbiór sztuki (przeżycia wywołane przez sztukę). W myśl jego poglądów wychowanie przez sztukę jest wychowaniem wszechstronnym, obejmującym zarówno kształcenie kultury estetycznej, jak i wykorzystanie sztuki i przynależnych jej procesów w kształtowaniu osobowości człowieka. Autor wskazuje na trzy aspekty wychowawczego wpływu: poznawczy, kompensacyjny i ekspresywny. Poznawcze właściwości sztuki realizują się poprzez kontakt z zewnętrzną i wewnętrzną rzeczywistością reprezentowaną w dziele - jej emocjonalne przeżycie prowadzi do przekształcenia (myśli, uczuć), a tym samym wzbogacenia percypującego podmiotu. Funkcję kompensacyjną Suchodolski wiąże z możliwością ekspresji i realizacji wewnętrznych doświadczeń (dążeń, potrzeb, pragnień) w świecie fikcyjnym, wyobrażonym. Ekspresywny wymiar sztuki ujawnia się w możliwości wyrażenia wewnętrznych konfliktów i niepokojów inicjowanych $\mathrm{w}$ zetknięciu z powołaną $\mathrm{w}$ dziele rzeczywistością oraz określenia (uświadomienia sobie) subiektywnych interpretacji doświadczeń ${ }^{18}$. Sztuka

13 Zob.: B. Nawroczyński, O wychowaniu estetycznym, [w:] Teoria wychowania estetycznego..., s. 121 .

14 Szuman określał tego rodzaju twórczość jako dyletancką.

15 Określenie „twórczość naiwna” odnosi się do twórczości dorosłych niebędących artystami, których stylistyka nawiązuje w sposób nieświadomy do stylistyki dziecka.

16 Zob.: S. Morawski, Trojaka funkcja wychowawcza sztuki, „Estetyka”, nr 4/1963, s. 26.

17 Zob.: B. Suchodolski, Podstawy wychowania socjalistycznego, Warszawa 1967, s. 142.

18 Tenże, Wychowanie dla przyszłości, Warszawa 1968; Tenże, Wychowanie przez sztukę, [w:] I. Wojnar (red.), Wybór tekstów, Warszawa 1997, s. 162-168. 
w jego koncepcji jest zatem narzędziem kształtowania osobowości człowieka poprzez ściśle zaplanowane działania pedagogów.

Wojnar wskazuje na cztery zasadnicze wątki problemowe wyłaniające się z założeń przyjmowanych we współcześnie rozwijanych koncepcjach wychowania estetycznego: 1) kształcenie kultury estetycznej, 2) kształcenie świadomego stosunku do wartości estetycznych zawartych w sztuce, rzeczywistości społecznej i fizycznej (otoczeniu materialnym), 3) wychowanie moralne i umysłowe oraz 4) inspirowanie postaw twórczych ${ }^{19}$. Analiza idei działań pedagogiczno-artystycznych zapoczątkowanych w drugiej połowie XX wieku przez artystów i pedagogów działających w różnych kręgach artystycznych i naukowych pozwala na wyłonienie jeszcze jednego ujęcia skoncentrowanego na rozwoju podmiotowym, inspirowanym doświadczeniami inicjowanymi w obszarze sztuki. Ujęcie to, zakorzenione w estetyce, dopełnia obraz wychowawczego wymiaru sztuki.

Inna koncepcja wychowania estetycznego pod nazwą „muzeum wyobraźni” (musée imaginaire ${ }^{20}$ została zaproponowana przez Andre Malraux. Jej przesłaniem było dążenie do szerokiego upowszechniania sztuki i umożliwienie jej odbioru wolnego od narzuconych z góry kontekstów. Malraux koncentruje się na interakcji między kulturami i tworzeniu w ich konsekwencji znaczeń i sensów. Owe znaczenia i sensy są, jego zdaniem, interpretowane i współkonstytuowane ${ }^{21} \mathrm{w}$ zetknięciu się różnych kultur - tak dzieje się w przypadku recepcji dzieł sztuki pochodzących z innej epoki lub kręgu kulturowego niż odbiorca. W tradycyjnym muzeum duży wpływ na interpretację znaczeń i sensów ma kontekst narzucony przez aranżację wystawy, dlatego autor postuluje rezygnację $\mathrm{z}$ tradycyjnych form wystawiennictwa, $\mathrm{tj}$. zastąpienie dzieł artystycznymi reprodukcjami lub fotografiami, a wystawę w sali muzealnej proponuje zastąpić albumem z fotografiami dzieł (tzw. papierowe muzeum). Pozwoli to, jego zdaniem, nie tylko na swobodny dostęp do eksponatów (reprodukcji), ale też na ich niezależny dobór przez odbiorcę - to on będzie decydował, co ogląda i w jakiej kolejności, budując w ten sposób osobisty kontekst. Tak pojęte muzeum zostanie uwolnione nie tylko od miejsca, ale też od czasu i kontekstu historii ${ }^{22}$, stanie się prywatną przestrzenią interpretacji ${ }^{23}$.

Trzeba dodać, że kategoria imaginarium rozpatrywana jest przez Malraux w trzech aspektach, jako:

- wyobrażeniowa przestrzeń odbiorcy (uczestnika kultury),

- kreacja artystyczna,

- muzeum ${ }^{24}$.

${ }^{19}$ I. Wojnar, Teoria wychowania estetycznego..., s. 285.

${ }^{20} \mathrm{~W}$ ostatnich latach konkurencyjna jest nazwa „muzeum bez ścian”, będąca polskim przekładem jednej z angielskich wersji tłumaczeń (museum without walls); podaję za: L. Dziedzic, „Muzeum wyobraźni” Andrè Malraux. Idea i praxis, „Studia Muzealno-Historyczne” nr 5/2013, s. 219-233.

${ }^{21}$ Zob.: J. Hańderek, Sztuka w muzeum wyobraźni, „Estetyka i Krytyka”, nr 2(21)/2011, s. 61-75.

22 L. Dziedzic, dz. cyt.

${ }^{23}$ J. Hańderek, dz. cyt.

${ }^{24}$ Tamże. 
Muzeum imaginacji spełnia różne role: 1) ukazuje symbole i kody kulturowe, tworzone na ich bazie sensy i znaczenia mające swoje odniesienie w kulturze, 2) przenosi je (sensy i znaczenia) do współczesności, przywracając je niejako kulturze, 3) jest przestrzenią refleksji (egzystencjalnych, tożsamościowych), inicjowanych u odbiorcy w zetknięciu z dziełem, a za jego pośrednictwem z wcześniejszą kulturą, wpływając tym samym na kreowanie jednostkowej egzystencji za pośrednictwem kultury ${ }^{25}$.

Należy zauważyć - za Leszkiem Dziedzicem ${ }^{26}$ - że zasługą Malraux było właściwie tylko dostrzeżenie i nazwanie zjawiska funkcjonującego już od starożytności $i^{27}$ - chodzi tu o wykonywanie kopii rzeźb. Również w renesansie kopie dzieł były wykonywane powszechnie, a w XVIII i XIX wieku muzea wystawiały kopie zamiast oryginału, często w celach porównawczych; czasem powstawały nawet muzea z założenia eksponujące kopie dzieł (np. Musée de Sculpture Comparée w Paryżu, Muzeum Sztuk Pięknych im. Aleksandra III w Moskwie) ${ }^{28}$.

Dla przybliżenia całościowego obrazu problematyki leżącej u źródeł formowania się koncepcji wychowania estetycznego istotne jest przytoczenie poglądów Johna Deweya. Wartości wychowawczych sztuki upatrywał on w jej właściwościach inicjowania doświadczenia podmiotowego oraz pobudzania wyobraźni.

Dla formułowania koncepcji wychowania estetycznego istotna była deweyowska koncepcja doświadczenia. W myśl jego poglądów doświadczenie konstytuuje się $\mathrm{w}$ interakcji podmiotu (organizmu) z otoczeniem. Człowiek nie jest samowystarczalny i odrębny - jest stworzony w doświadczeniu i przez doświadczenie. Samoświadomość, myśli, pojęcia i działania są wobec doświadczenia wtórne. Dewey zakłada, że człowiek „staje się" nie na bazie myśli, lecz na bazie doświadczenia, a ono samo pozwala człowiekowi na poznanie natury (rzeczywistości) ${ }^{29}$.

Dewey upatrywał największych możliwości aktualizowania się doświadczenia w sztuce, stąd szczególne znaczenie w poznawaniu rzeczywistości przypisywał przeżyciu estetycznemu, zaś samą sztukę (jej dzieła), uważał za zintensyfikowaną formę doświadczenia człowieka. Doświadczenie estetyczne nie ma, zdaniem autora, innych celów poza samym sobą, jest traktowane jako cel sam w sobie. Treścią tego doświadczenia jest przyjemność czerpana bezpośrednio z odbioru sztuki. Jego istotą nie jest jednak kontemplacja dzieła, ale doświadczenie własnej kreatywności w odczuciu związku z naturąa ${ }^{30}$.

${ }^{25}$ Zob.: tamże

${ }^{26}$ L. Dziedzic, dz. cyt., s. 222.

27 Tamże.

${ }^{28}$ J. Białostocki, O replikach i kopiach - dawniej i dziś, [w:] tegoż, Refleksje i syntezy ze świata sztuki, Warszawa 1978, s. 225-233; podaję za: L. Dziedzic, dz. cyt.

${ }^{29}$ N. Rachoń, Doświadczenie estetyczne w metafizyce naturalizmu empirycznego Johna Deweya, „Zeszyty Naukowe Akademii Marynarki Wojennej” R. LI : 2010, nr 4(183), s. 225-246, http://www. amw.gdynia.pl/library/File/ZN\%202010/19Rachon\%20N.pdf (dostęp: 2.08.2017).

${ }^{30}$ J. Dewey, Sztuka jako doświadczenie, Wrocław 1975. 
Poglądy na sztukę i doświadczenie estetyczne znalazły implikacje w pedagogice Deweya. Autor postulował, że sztuka i zawarte w niej wartości estetyczne powinny być obecne w wychowaniu od okresu wczesnego dzieciństwa, ze zwracaniem uwagi na właściwości kształtowania wrażliwości i rozwijania postawy twórczej. Należy tu wyjaśnić, że twórczość była kluczowym pojęciem w pedagogice Deweya, traktował ją jako wyraz ekspresji człowieka, przejawiającej się zarówno w sztuce, jak i w codziennych działaniach. Upatrywanie w niej możliwości pomnażania wartości humanistycznych w procesie przekształcania przyrody i stosunków społecznych oraz przypisywanie w tym zakresie szczególnej funkcji sztuce ${ }^{31}$ składa się na deweyowski panestetyzm, zakładający łączność sztuki z życiem społecznym ${ }^{32}$.

Poglądy na rolę sztuki w wychowaniu przedstawione w przytoczonych powyżej koncepcjach nie wyczerpują całości problematyki, ich wybór został podyktowany reprezentatywnością dla kierunków myślenia o statusie sztuki w edukacji.

\section{Sztuka jako przestrzeń edukacji - idee edukacji plastycznej rozwijane w latach 80 . XX wieku przez grupę pARTner}

\section{Założenia przyjmowane przez grupę pARTner i ich podstawy teoretyczne}

Zmiana założeń edukacyjnych, a przede wszystkim postulowane przez pedagogów (m.in. Szumana ${ }^{33}$ i Nawroczyńskiego ${ }^{34}$ ) oddzielenie idei kształcenia artystycznego od idei wychowania estetycznego, utorowało drogę do kształtowania modelu kształcenia zakładającego wykorzystanie sztuki do realizacji celów wychowawczych zgodne z koncepcją wychowania przez sztukę. W jej przeszczepieniu na grunt praktyki pedagogicznej wielkie zasługi należy przypisać Irenie Wojnar, która upowszechniała ją w kręgach nauczycielskich.

Postulaty wykorzystania sztuki w wychowaniu formułowane na gruncie teorii wychowania estetycznego znalazły odzwierciedlenie w działaniach podejmowanych w kręgach postępowych pedagogów i artystów zajmujących się w praktyce edukacją artystyczną. Przykładem są tu realizacje grupy pARTner działającej w latach 1983$1986^{35}$. Tworzyli ją postępowi artyści i pedagodzy: Jacek Bukowski, Janusz Byszewski,

${ }^{31}$ Chodzi tu o poglądy dotyczące wzbudzania doświadczenia estetycznego w wielu działaniach człowieka (tj. nie tylko w kontakcie ze sztuką) oraz przyczynianiu się kontaktu ze sztuką do rozwoju wrażliwości i postaw innowacyjnych, niezbędnych do budowania poprawnych stosunków społecznych.

32 W. Kaczocha, Panestetyzm Johna Deweya, „Sztuka i Filozofia”, nr 3/1990, s. 161-170; http:// bazhum.muzhp.pl/media//files/Sztuka i Filozofia/Sztuka i Filozofia-r1990-t3/Sztuka i Filozofia -r1990-t3-s161-170/Sztuka i Filozofia-r1990-t3-s161-170.pdf (dostęp: 2.09.2017).

${ }_{33}$ Zob.: S. Szuman, Specyfika wychowania estetycznego, [w:] Teoria wychowania estetycznego. Wybór..., s. 146.

${ }^{34}$ Zob.: B. Nawroczyński, O wychowaniu estetycznym, [w:] Teoria wychowania estetycznego. Wybór..., s. 112-128.

${ }^{35}$ Nazwa grupy została zapożyczona, jej twórcą był niemiecki artysta Mail - Artur Michael Groschopp. 
Blanka Gul-Olszewska, Eugeniusz Józefowski, Wiesław Karolak (początki nowatorskich działań członków grupy miały miejsce przed jej ukonstytuowaniem się). Na ich działalność składały się nowatorskie realizacje z zakresu sztuki (głównie teatru i sztuk plastycznych), oferowane dzieciom i młodzieży, organizowane we współpracy z instytucjami zajmującymi się sztuką ${ }^{36}$. Ich istotą było inspirowanie działań twórczych zmierzających do realizacji projektów artystycznych. Forma tych propozycji odbiegała diametralnie od rozwiązań metodycznych stosowanych wówczas w placówkach edukacyjnych, które trzymały się ściśle zasad organizacyjnych lekcji. Różnica dotyczyła też idei edukacji - o ile tradycyjne metody posługiwały się metodami podającymi i ćwiczeniowymi, o tyle w omawianych propozycjach źródłem poznania miały być doświadczenia tworzącego podmiotu.

Analiza założeń przyświecających realizacjom pARTnera wskazuje na ich teoretyczne osadzenie w koncepcji wychowania przez sztukę, co z pewnością było wynikiem ścisłych kontaktów naukowych z prof. Ireną Wojnar - Jacek Bukowski był jej asystentem, Wiesław Karolak współpracował z nią na polu zawodowym, natomiast inni członkowie grupy mieli możliwość zapoznania się z postulatami koncepcji w ramach organizowanych przez prof. Wojnar konferencji naukowych. Artystyczno-pedagogiczny manifest pARTnera obejmował postulaty rozwoju pogłębionej komunikacji intra- i interpersonalnej w procesie współtworzenia sztuki. Przyjmowano, że owo współtworzenie zachodzi zarówno w procesie aktywnej percepcji dzieła ${ }^{37}$, jak i podczas kreacji obiektu artystycznego. Partycypację w tworzeniu dzieła osobom niebędącym artystami zapewniają realizacje z zakresu sztuki współczesnej, stąd propozycje artystyczne formalnie mieściły się w zakresie sztuki interaktywnej ${ }^{38}$, której cechą jest przesunięcie koncentracji z formy (artefaktu) na treść doświadczeń uczestników działania. Kładziono akcent na partnerstwo przeżyć, partnerstwo w twórczej aktywności, postulowano zwrócenie się $k u$ drugiej osobie $w$ działaniach artystycznych i paraartystycznych, $z$ chęcia lepszego poznania się i pełniejszego wzajemnego zrozumienia ${ }^{39}$. W myśl przyjętych poglądów sztuka miała być pomostem ułatwiającym zrozumienie siebie i innych, zaś płaszczyzną nawiązywania relacji ukierunkowanych na drugiego człowieka miał być proces twórczy aktywizowany w jej przestrzeni.

Propozycje metodyczne pARTnera, respektujące postulaty odnośnie wychowania estetycznego, sformułowane przez Janinę Mortkowiczową, Stefana Szumana, Bogdana Suchodolskiego, Herberta Reada i Irenę Wojnarową można traktować jako prak-

${ }^{36}$ Współpracowano m.in. z Galerią Biura Wystaw Artystycznych we Wrocławiu, Łodzi, Instytutem Wzornictwa Przemysłowego w Warszawie, Galerią Foto-Medium-Art we Wrocławiu, Pałacem Kultury i Nauki w Warszawie.

${ }^{37}$ Zob.: R. Ingarden, Przeżycie - dzieło - wartość, Kraków 1966.

${ }^{38}$ Przez sztukę interaktywną rozumie się działania artystyczne zaliczane do sztuki współczesnej, które cechuje przesunięcie koncentracji z dzieła - artefaktu - na proces twórczy i towarzyszące mu interakcje. Wyniesione z nich doświadczenia wypełniają treścią dzieło, określając jego ostateczną formę.

${ }^{39}$ J. Bukowski i inni, Partner. Działania artystyczne z dziećmi, BWA, Wrocław 1984. 
tyczne realizacje zarysowanej przez tych autorów możliwości szerszego wykorzystania potencjału sztuki w edukacji. O ile jednak w rozwijanych przez nich koncepcjach ciągle jeszcze eksponowano percepcyjny aspekt sztuki związany z kształtowaniem kultury estetycznej, o tyle założenia przyjmowane przez grupę pARTner koncentrowały się na jej aspekcie czynnościowym, czyli procesie kreacji. Różnica w omawianych podejściach jest uwarunkowana dwoma czynnikami - dyscypliną, w której są osadzone, oraz przyjmowaną koncepcją sztuki. Koncepcje wychowania estetycznego cechuje silne zakorzenienie w pedagogice, czego konsekwencją jest akcentowanie roli nauczyciela jako mistrza, który czerpiąc z własnych kompetencji zawodowych projektuje działania wychowawcze, w których posługuje się wartościami zawartymi w sztuce. Sztuka zostaje więc sprowadzona do roli środka wychowania, swoistego instrumentu ${ }^{40}$, narzędzia umożliwiającego realizację zaplanowanych celów. Środki artystyczne i aktywności przypisane sztuce zostają więc przeniesione na grunt działań wychowawczych, a ich oddzielenie od sztuki niesie za sobą ograniczenia jej roli - kluczowym czynnikiem $\mathrm{w}$ tak rozumianym wychowaniu staje się zamysł postępowania dydaktycznego. Pedagogiczna perspektywa poszerza pojęcie sztuki, włączając w jej zakres szereg działań nieprzynależących już formalnie do jej świata. Są to działania ukierunkowane na inicjowanie aktywności i wyzwalanie potencji twórczych czy stwarzanie możliwości ekspresji u dzieci i młodzieży z użyciem środków przynależnych sztuce, jednak z wyłączeniem udziału artystów. Owo utożsamianie sztuki z twórczością i ekspresją, jakie dokonało się na gruncie pedagogicznym, jest wyrazem poszukiwania nowych metod, jednak postulowane podejście do sztuki wymaga gruntownej rewizji.

Założenia wypracowane w grupie pARTner wywodzą się z estetyki, stąd eksponuje się w nich właściwości edukacyjne sztuki związane z inicjowaniem rozwoju podmiotowego w jej przestrzeni. Proponowane środki wyrazu i formy aktywności nie wykraczają poza tę przestrzeń, co daje uczestnikom działań możliwość partycypacji w tworzeniu sztuki. Biorąc udział w animowanych przez artystę aktywnościach, wypełniają proponowaną przez niego formę artystyczną podmiotową treścią, wnosząc wkład w ostateczny kształt tworzonego dzieła.

W założeniach przyjętych przez grupę pARTner widoczna jest inspiracja myślą pedagogiczną rozwijaną na gruncie nurtu Nowego Wychowania, w której za istotę wychowania przyjmowano autokreację, wolność i twórczość oraz głoszono zasadę indywidualizmu i rozwoju ${ }^{41}$. Czytelne jest również odniesienie do deweyowskiego pragmatyzmu, promującego ideę aktywizmu, wyrażoną w postulacie uczenia się przez doświadczenie i działanie ${ }^{42}$ oraz jego koncepcji doświadczenia estetycznego. W myśl poglądów Deweya doświadczenie wykracza poza sam udział w proponowa-

\footnotetext{
40 I. Wojnar, dz. cyt., s. 285.

41 S. Sztobryn, Pedagogika Nowego Wychowania, [w:] Z. Kwieciński, B. Śliwerski (red.), Pedagogika, T. 1., s. 286-287.

42 J. Dewey, Demokracja i wychowanie, Wrocław 1952, s. 199.
} 
nym działaniu, rozumiany jako realizacja przypisanych mu zadań - istotną częścią doświadczenia jest refleksja powstała w wyniku podjętej przez podmiot aktywności.

Poszukując analogii omawianych założeń na gruncie estetyki, można wskazać na zbieżność z postulatami estetyki zaangażowania Arnolda Berleanta ${ }^{43}$, odnoszącymi się do roli doświadczenia estetycznego w poznaniu rzeczywistości. W myśl jego poglądów doświadczenie generowane jest w polu estetycznym wyznaczanym przez interakcje zachodzące między artystą, poznającym podmiotem (odbiorcą, uczestnikiem działań artystycznych - wtrącenie J. F.) a strukturą artefaktu (przedmiotem poznania - wtrącenie J. F.). Owo doświadczenie prowadzi do zmian w myśleniu i odczuwaniu zaangażowanego podmiotu. Należy wspomnieć, że pojęcie doświadczenia jest tu rozumiane odmiennie niż w kantowskiej propozycji traktowania go jako dualnego przeciwstawienia podmiotu i przedmiotu, powstającego w dystansie między nimi ${ }^{44}$. Wychodząc od deweyowskiego ujęcia doświadczenia, Berleant przyjmuje postulat ciągłości między przedmiotem a podmiotem. W świetle jego poglądów doświadczenie jest wynikiem interakcji między nimi - przedmiot staje przedłużeniem podmiotu, a ich zanurzenie we wspólnym kontekście znosi podział na rzeczywistość zewnętrzną i wewnętrzną (podmiotową). Doświadczenie estetyczne ma charakter zintegrowany, obejmuje całokształt możliwej aktywności podmiotu, tj. doznania zmysłowe, intelektualne oraz duchowe ${ }^{45}$.

W myśl programu artystycznego przyjętego przez grupę pARTner doświadczenie wzbudzane w przestrzeni sztuki wiąże się z partycypacją w jej tworzeniu. Wymaga to zaoferowania działań dających możliwość swoistego „zanurzenia się” w sztuce. Tłumaczy to skoncentrowanie się na procesie twórczym, treściach inicjowanego w nim doświadczenia i jego związkach z rozwojem podmiotowym uczestników, którego miarą jest poszerzenie poznania świata zewnętrznego (w aspektach: fizycznym i społecznym) i wewnętrznego, czyli poznania siebie. Proponowane działania przyjmują formy akcji plastycznej, happeningu czy warsztatu twórczego, mieszcząc się w obszarze sztuki interaktywnej, której cechą jest koncentracja na samym procesie tworzenia i towarzyszących mu doświadczeniach. Uczestnicy partycypują w sztuce, wypełniając podmiotową treścią formy proponowane przez artystów. Ostateczny kształt „dzieła” jest wypadkową koncepcji artysty i działań podjętych przez uczestników, aczkolwiek samo dzieło rozumiane jest jako zbiór doświadczeń uczestników zainicjowanych w działaniu - procesie twórczym, a nie jako materialny jego wynik w postaci artefaktu. Odrzuca się konieczność istnienia $w$ dziele wartości estetycznych, ich znaczenie za-

${ }^{43}$ A. Berleant, Prze-myśleć estetykę. Niepokorne eseje o sztuce, Kraków 2007.

${ }^{44}$ K. Wikoszewska, Arnolda Berleanta projekt estetyki postkantowskiej, „Sztuka i Filozofia”, nr 37/2010, s. 38-47.

${ }^{45}$ A. Berleant, dz. cyt. 
węża się do odczucia wywołanego przeżyciem estetycznym oraz strukturalnymi i zmysłowymi wartościami formy dzieła ${ }^{46}$.

Postrzeganie sztuki w kategoriach przestrzeni inicjującej pożądane zmiany wpisuje się w trendy pedagogiczne XX wieku, promujące koncepcję edukacji opartej na zasadach humanizmu i pragmatyzmu. Tak pojmowaną edukację cechuje odejście od autorytaryzmu w wychowaniu, tj. rezygnacja z narzucania gotowej wiedzy na rzecz jej tworzenia przez wychowanków na bazie doświadczeń wyniesionych z oferowanych im działań. Głównym zadaniem wychowawcy/ nauczyciela jest organizowanie środowiska wyposażonego w bodźce inicjujące procesy samorozwoju, co daje się osiągnąć między innymi przez aranżowanie sytuacji edukacyjnych inicjujących doświadczenie podmiotowe.

Formy aktywności oferowane przez członków grupy pARTner były przeznaczone do realizacji w pozaszkolnych formach kształcenia, bowiem ich zastosowanie w kształceniu szkolnym wymagałoby zmiany organizacyjnej związanej z odstąpieniem od 45-minutowego cyklu tradycyjnie pojmowanej lekcji plastyki. Sami artyści podkreślali zresztą negatywny wpływ przyzwyczajeń szkolnych na aktywność partycypowania w proponowanych działaniach, który zaznaczał się głównie w postaci blokady działań twórczych, wymagających podejmowania zachowań artystycznych wykraczających poza przyjęte standardy narzucone wymogami techniki czy dyscypli$n y^{47}$. Przyświecająca im idea wspomagania rozwoju za pośrednictwem doświadczeń inicjowanych w przestrzeni sztuki, będąc osadzoną w estetyce, zawiera istotne implikacje dla praktyki pedagogicznej, które zaowocowały wypracowaniem alternatywnych dla tradycyjnych metod edukacji plastycznej.

\section{Opis wybranych realizacji grupy pARTner}

Celem przybliżenia koncepcji edukacji plastycznej wypracowanej przez grupę pARTner, poniżej opisane zostały trzy wybrane realizacje z działań grupy przeprowadzonych w Instytucie Wzornictwa Przemysłowego w Warszawie w czerwcu 1984 roku.

Eugeniusz Józefowski, „Magiczne pismo”48 (fot. 1-2)

Ideą tego działania było wzbudzenie refleksji nad funkcją znaku i jego plastyczną wartością. Łączyło ono w sobie cechy akcji plastycznej i warsztatu twórczego ukierunkowanie na refleksyjność zbliżało je do koncepcji warsztatu, jednak nie zawierało w sobie wszystkich jego elementów. Rolę treningu wyobrażeniowego pełniła rozmowa na temat symboliki pisma, znaków graficznych, piktogramów i znaków runicznych. Stanowiła ona inspirację do kreacji. Tworzywem były kamienie - otoczaki. Ułożono je na podłodze galerii w kwadratach wytyczonych taśmą. W każdym z nich mieściło się po sto kamieni, na dwudziestu jeden farbą naniesiono znaki tak, jakby były literami i zdaniami tworzacymi tajemniczy

${ }^{46}$ E. Józefowski, Wyobraźnia i obraz jako czynniki konstytuujące warsztat twórczy przy kreacji wizualnej, „Dyskurs: Pismo Naukowo-Artystyczne ASP we Wrocławiu”, nr 17/2014, s. 285-286.

47 E. Józefowski, Edukacja artystyczna w działaniach warsztatowych, Łódź 2009, s. 8.

${ }^{48}$ Działanie to jest opisane w literaturze również pod nazwą „Magiczny zapis”. 
$z a p i s^{49}$. Zapis ten był zaproszeniem dla uczestników do jego kontynuowania zgodnie z własną interpretacją i rozumieniem. Tworzony obiekt przyjął formę książki artystycznej, złożonej ze stron o formacie 200 x $200 \mathrm{~cm}^{50}$.

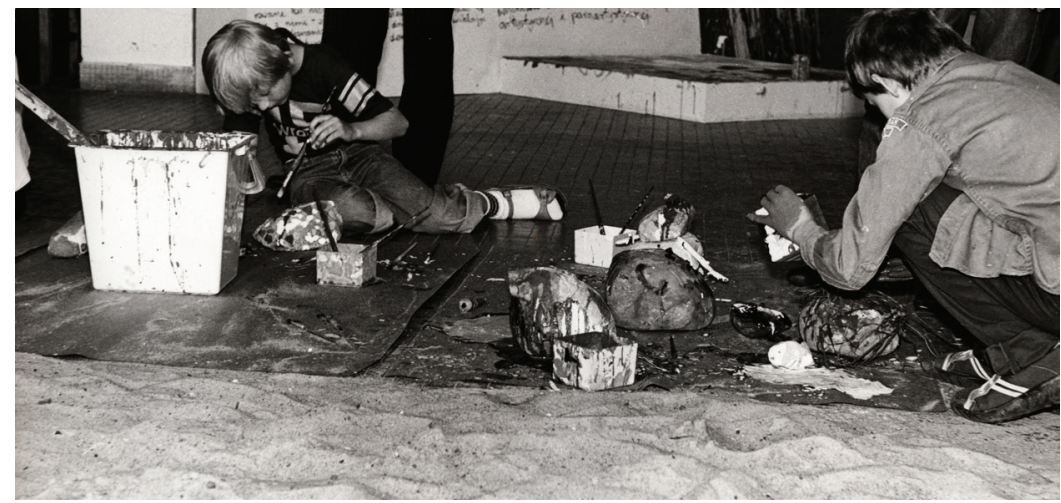

Fot. 1 (fot. Marianna Kacprzak)

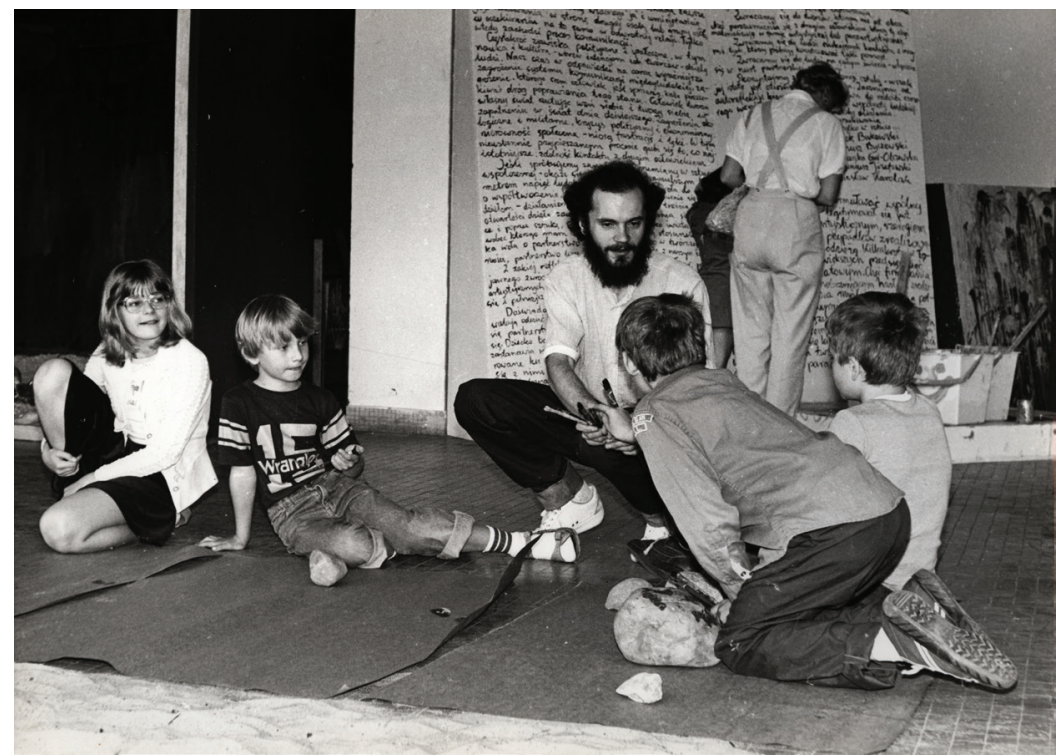

Fot. 2 (fot. Marianna Kacprzak)

${ }^{49}$ E. Józefowski, Magiczne pismo, [w:] M. Jasser, J. Byszewski (red.), pARTner.'84,'85, Katalog Biennale Sztuki dla Dziecka, KAW, RSW Książka-Prasa-Ruch, Poznań 1985.

${ }^{50}$ Tamże; E. Józefowski, Książka o książkach, WSP, Zielona Góra 1999, s. 15-16. 
Wiesław Karolak, „Inne rysowanie” (fot. 3-4)

Zaproponowane działanie było akcją plastyczną o charakterze zabawy. Jej celem było przybliżenie zagadnień kompozycji oraz jej oddziaływania przestrzennego i emocjonalnego w sposób niestandardowy, bowiem miały być one przyswajane $\mathrm{w}$ doświadczeniach towarzyszących działaniom. Tworzywem wykorzystanym do plastycznych przekształceń były gazety. Poddano je zginaniu, zgniataniu, wydzierano z nich kawałki; wszystko to celem realizacji zlecanych zadań: m.in. tworzenia punktów, linii, płaszczyzny, bryły, niekończącej się linii; przedstawiania tematów: „Ja”, „Droga”, „Miasto” czy wykonania ubioru ${ }^{51}$.

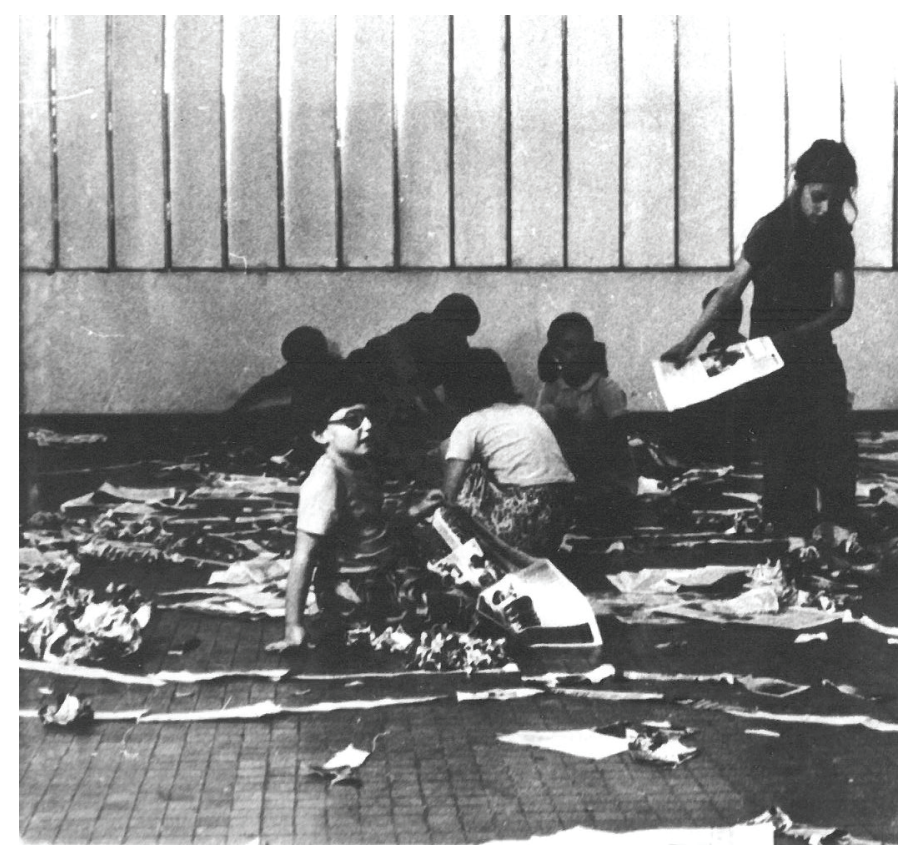

Fot. 3 (ze zbiorów J. Byszewskiego)

${ }^{51}$ W. Karolak, Inne rysowanie, [w:] pARTner'84,'85..., dz. cyt. 


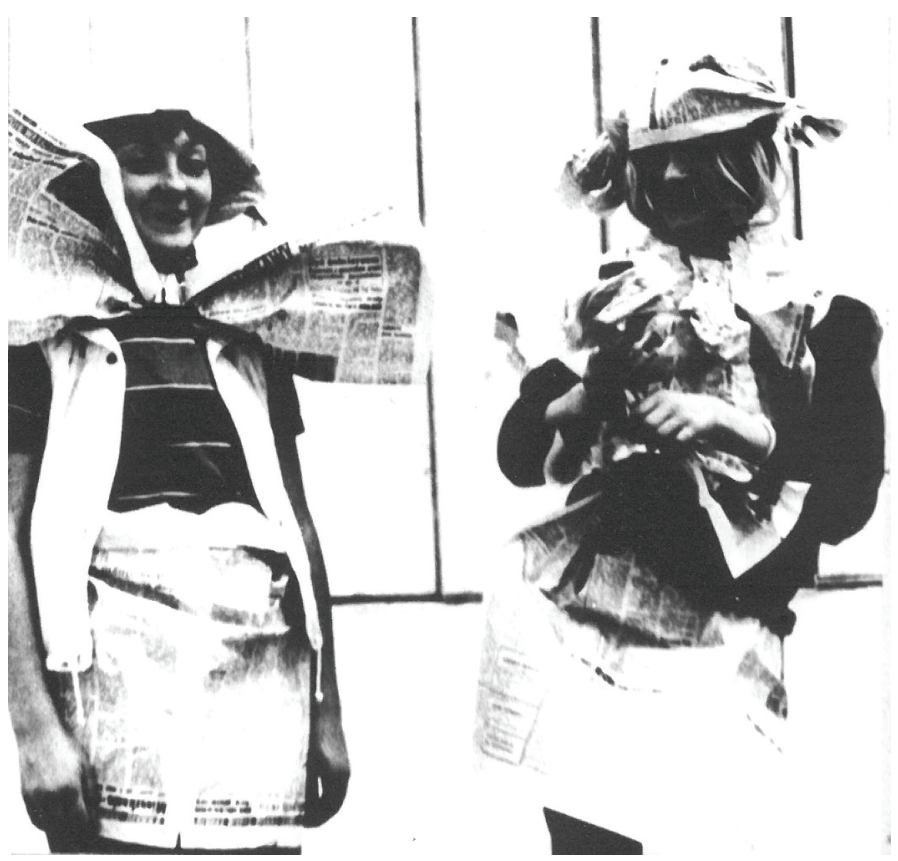

Fot. 4 (ze zbiorów J. Byszewskiego)

Janusz Byszewski, „Rekonstrukcja” (fot. 5-6)

Celem akcji było budowanie tożsamości kulturowej poprzez wywołanie refleksji odnoszącej się do pozostałości dawnej architektury, tworzących obecnie ruiny. Podłożem zaplanowanej dla uczestników pracy malarskiej były płócienne ekrany, na których wyświetlono fotografie przedstawiające pozostałości po wyburzonych domach. Na ocalałych ścianach widniały kolorowe pozostałości tynków, drzwi, ślady po obrazach. Obok tej instalacji video eksponowane były czarno-białe fotografie przedstawiające te same ruiny. Zadaniem uczestników było malarskie wypełnienie wnętrz wyświetlanych ścian, ich „ożywienie” na nowo sprzętami, meblami, osobami. Dodatkową inspiracją były nagrania odgłosów domów, m.in. pukanie do drzwi, trzepanie dywanów, stukanie naczyń, fragmenty rozmów ${ }^{52}$.

${ }^{52}$ J. Byszewski, Rekonstrukcja, [w:] pARTner'84,'85, dz. cyt. 


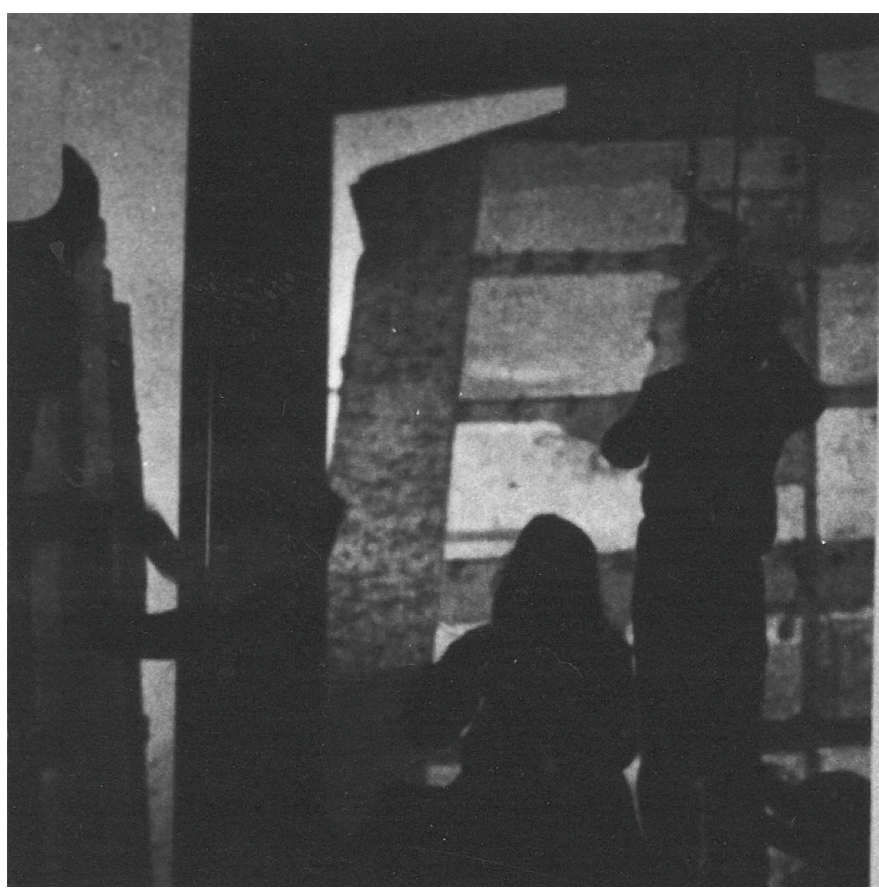

Fot. 5 (ze zbiorów J. Byszewskiego)

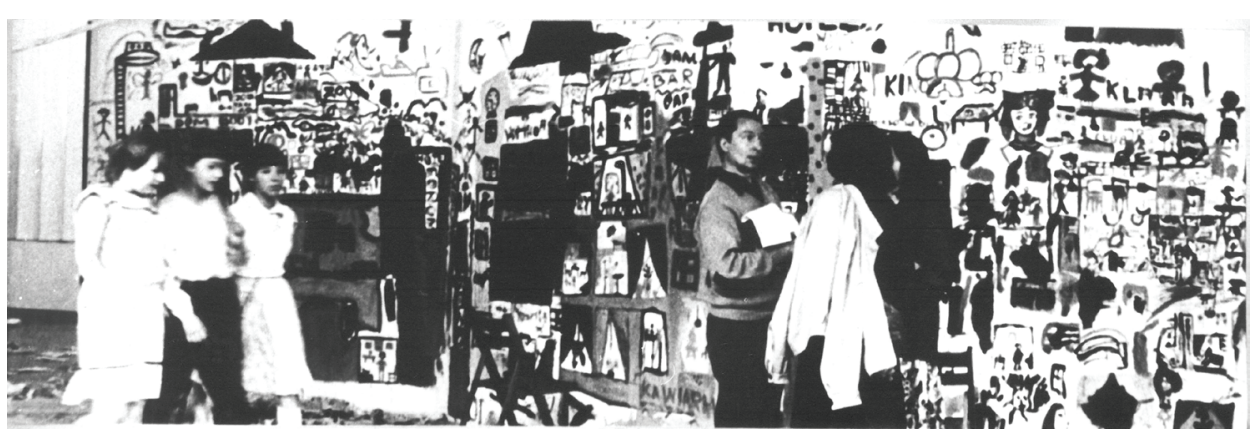

Fot. 6 (ze zbiorów J. Byszewskiego)

\section{Podsumowanie}

W prowadzonej obecnie naukowej dyspucie nad teoretycznym osadzeniem edukacji odwołania do koncepcji wychowania estetycznego zdarzają się sporadycznie. Nie oznacza to jednak, że wypracowane w ich ramach postulaty wskazujące na wychowawczą rolę sztuki uległy zapomnieniu. Obecne podejście znacznie szerzej ujmu- 
je znaczenie sztuki, odwołując się do jej roli w kształtowaniu osobowości. Konkurencyjne dla koncepcji wychowania estetycznego stały się dziś koncepcje arteterapii, w których postuluje się wykorzystanie właściwości sztuki w procesie terapeutycznym i/lub edukacyjnym. Pojawienie się tej kategorii w obszarze edukacji jest niewątpliwie wynikiem dążenia do holistycznego, interdyscyplinarnego ujęcia zjawisk. Koncepcje arteterapii, zyskując ogromną popularność wśród praktyków, spychają koncepcje wychowania estetycznego na margines pedagogiki. W ślad za tym pojawiła się tendencja do instrumentalnego traktowania sztuki. Jej rola w edukacji coraz częściej jest sprowadzana jedynie do narzędzia, co należy uznać za przejaw jej deprecjonowania.

Podobne wnioski przynosi refleksja nad obecną edukacją plastyczną. Namacalnym dowodem deprecjonowania sztuki w edukacji instytucjonalnej było wprowadzenie do szkół w 1999 roku przedmiotu o nazwie „sztuka” w miejsce przedmiotów plastyka i muzyka przy jednoczesnym ograniczeniu liczby godzin przeznaczonych na ich realizację $e^{53}$.

Działania grupy pARTner stanowiły bezpośrednią implementację założeń wychowania estetycznego do pozainstytucjonalnej praktyki edukacyjnej poszerzonych o własne poglądy. Proponowane przez nich nowatorskie metody edukacji plastycznej oddziaływały z dużą siłą na praktyków (nauczycieli wychowania plastycznego, wychowania przedszkolnego i nauczania początkowego ${ }^{54}$ ), którzy przenosili te propozycje do praktyki szkolnej. Współczesna edukacja plastyczna, rozumiana jako praktyka nauczania w zakresie plastyki, boryka się z trudnościami wynikającymi z braku teoretycznego odniesienia. Postulaty wychowania estetycznego rozwijane w XX wieku nie przystają już do obecnej rzeczywistości społecznej i edukacyjnej oraz ich potrzeb. Również oddziaływanie ośrodków akademickich w tym zakresie wydaje się słabnąćs5. Wobec powyższego, dziś coraz wyraźniej zaznacza się potrzeba aktualizacji teorii wychowania estetycznego i wypracowanie w jej ramach koncepcji edukacji plastycznej, nie tylko odpowiadającej treściowo zmieniającym się wymogom edukacji, ale i reagującej na zmiany dokonujące się w sztuce.

${ }^{53}$ Zob.: Rozporzadzenie MEN z 15 lutego 1999 r. w sprawie ramowych planów nauczania w szkołach publicznych, Dz. U. z 1999 r. nr 14, poz. 128; na realizację przedmiotu sztuka przeznaczono 1 godzinę tygodniowo w klasach 4-6 szkoły podstawowej i klasach 1-3 gimnazjum (dotychczas realizowano każdy z przedmiotów w wymiarze 1 godziny tygodniowo) oraz 1 godzinę w klasie 1 liceum ogólnokształcącego na plastykę lub muzykę.

${ }^{54}$ Zastosowane tu nazwy przedmiotów i poziomów edukacji nie są aktualne, zastąpiono je nazwami: plastyka, edukacja wczesnoszkolna (wcześniej: kształcenie zintegrowane).

${ }^{55} \mathrm{~W}$ ostatnich dwóch dekadach wiodącą rolę w dyskusji nad edukacją w zakresie sztuki można przyznać zespołowi prowadzonemu przez prof. Wiesławę Limont na Uniwersytecie Mikołaja Kopernika w Toruniu. Organizowane przez ten zespół konferencje „Eduart” stały się płaszczyzną wymiany poglądów elastycznie odpowiadającą zmianom postępującym zarówno w obszarze edukacji, jak i sztuki. 


\section{Bibliografia}

Berleant A. Prze-myśleć estetykę. Niepokorne eseje o sztuce, Kraków 2007.

Białostocki J., O replikach i kopiach - dawniej i dziś, [w:] J. Białostocki (red.), Refleksje i syntezy ze świata sztuki, Warszawa 1978.

Bukowski J., Byszewski J., Józefowski E., Karolak W., Olszewska B., Sikorski T., Partner. Działania artystyczne z dziećmi, BWA, Wrocław 1984.

Byszewski J., Rekonstrukcja, [w:] M. Jasser (red.), pARTner.'84,'85. Katalog Biennale Sztuki dla Dziecka, KAW, RSW Książka - Prasa - Ruch, Poznań 1985.

Dewey J., Sztuka jako doświadczenie, Wrocław 1975.

Dewey J., Demokracja i wychowanie, Wrocław 1952.

Dziedzic I., „Muzeum wyobraźni” Andrè Malraux. Idea i praxis, „Studia Muzealno-Historyczne", nr 5/2013, s. 219-233.

Gołaszewska M., Kultura estetyczna, Warszawa 1997, [w:] I. Wojnar (red.), Teoria wychowania estetycznego - zarys problematyki, Warszawa 1976.

Gołaszewska M., Zarys estetyki, Warszawa 1984.

Hańderek J., Sztuka w muzeum wyobraźni, „Estetyka i Krytyka”, nr 2 (21)/2011, s. 61-75. Ingarden R., Przeżycie - dzieło - wartość, Kraków 1966.

Józefowski E., Edukacja artystyczna w działaniach warsztatowych, Łódź 2009.

Józefowski E., Książka o książkach, WSP, Zielona Góra 1999.

Józefowski E., Magiczne pismo, [w:] M. Jasser, J. Byszewski (red.), pARTner.'84,'85, Katalog Biennale Sztuki dla Dziecka, KAW, RSW Książka - Prasa - Ruch, Poznań.

Józefowski E., Wyobraźnia i obraz jako czynniki konstytuujące warsztat twórczy przy kreacji wizualnej, „Dyskurs: Pismo Naukowo-Artystyczne ASP we Wrocławiu", nr 17/2014, s. 285-286.

Kaczocha W., Panestetyzm Johna Deweya, „Sztuka i Filozofia”, nr 3/1990, s. 161-170; http://bazhum.muzhp.pl/media//files/Sztuka i Filozofia/Sztuka i Filozofia-r1990-t3/Sztuka i Filozofia-r1990-t3-s161-170/Sztuka i Filozofia-r1990-t3-s161-170.pdf (dostęp: 2.09.2017).

Karolak W., Inne rysowanie, [w:] M. Jasser, J. Byszewski (red.), pARTner.'84,'85. Katalog Biennale Sztuki dla Dziecka, KAW, RSW Książka - Prasa - Ruch, Poznań.

Milerski B., Śliwerski B., Pedagogika. Leksykon PWN, Warszawa 2000.

Morawski S., Trojaka funkcja wychowawcza sztuki, „Estetyka”, nr 4/1963.

Mortkowiczowa J., Estetyka wychowania, [w:] I. Wojnar (red.), Teoria wychowania estetycznego. Wybór tekstów, Warszawa 1997.

Nawroczyński B., O wychowaniu estetycznym, [w:] I. Wojnar (red.), Teoria wychowania estetycznego. Wybór tekstów, Warszawa 1997.

Read H., Wychowanie przez sztukę, Zakład Narodowy im. Ossolińskich, Wrocław 1976.

Rachoń N., Doświadczenie estetyczne w metafizyce naturalizmu empirycznego Johna Deweya, „Zeszyty Naukowe Akademii Marynarki Wojennej” R. LI: 2010, 
nr 4183), s. 225-246; http://www.amw.gdynia.pl/library/File/ZN\%202010/ 19Rachon\%20N.pdf (dostęp: 2.08.2017).

Rozporządzenie MEN z 15 lutego 1999 r. w sprawie ramowych planów nauczania w szkołach publicznych, Dz. U. z 1999 r. nr 14, poz. 128.

Suchodolski B., Podstawy wychowania socjalistycznego, Warszawa 1967.

Suchodolski B., Wychowanie dla przyszłości, Warszawa 1968.

Suchodolski B., Wychowanie przez sztuke, [w:] I. Wojnar (red.), Teoria wychowania estetycznego. Wybór tekstów, Warszawa 1997.

Szuman S., O sztuce i wychowaniu estetycznym, Warszawa 1969.

Szuman S., Sztuka wzbogaca i pogłębia człowieka, [w:] I. Wojnar (red.), Teoria wychowania estetycznego - zarys problematyki, Warszawa 1976.

Szuman S., Specyfika wychowania estetycznego, [w:] I. Wojnar (red.), Teoria wychowania estetycznego - zarys problematyki, Warszawa 1976.

Sztobryn S., Pedagogika Nowego Wychowania, [w:] Z. Kwieciński, B. Śliwerski (red.), Pedagogika,T. 1., s. 286-287.

Wikoszewska K., Arnolda Berleanta projekt estetyki postkantowskiej, „Sztuka i Filozofia”, nr 37/2010.

Wojnar I., Perspektywy wychowawcze sztuki, Warszawa 1966.

Wojnar I., Teoria wychowania estetycznego - zarys problematyki, Warszawa 1976.

\title{
Implementations of theoretical assumptions of aesthetic education in non-institutional arts education in the 1980's based on the example of pARTner group activity
}

\begin{abstract}
The article presents the idea of innovative actions in the field of artistic education, which were developed in the eighties in the twentieth century by members of the pARTner group. Proposed actions, while respecting demands developed the concept in Poland grown on the basis of aesthetic education, went beyond institutional forms of art classes. Differences also focused on its objectives and views on the role of the creative process in education. Analysis of the status of art in the contemporary theory of aesthetic education, which preceded these considerations, create the theoretical framework for the presented problem.
\end{abstract}

Keywords: aesthetic education, the practice of art education, the pARTner group, innovative methods of art education.

About the author: dr hab. Janina Florczykiewicz - Professor at the Faculty of Humanities in Siedlce University of Natural Sciences and Humanities. 


\title{
Dorota Grabowska-Pieńkosz ${ }^{*}$
}

Uniwersytet Mikołaja Kopernika w Toruniu

dogra@umk.pl

\section{Emocje w pracy nauczyciela w świetle źródeł pamiętnikarskich}

\begin{abstract}
Streszczenie: Celem artykułu jest zaprezentowanie znaczenia emocji w pracy pedagogicznej, ze szczególnym zwróceniem uwagi na sytuacje dydaktyczne i wychowawcze. Emocje mają zróżnicowany charakter i uwarunkowane są różnorodnymi czynnikami zarówno cechami osobowymi wychowawców, jak i zachowaniem wychowanków. Dlatego w artykule zdecydowano się odpowiedzieć na pytania: w jakim zakresie emocje nauczyciela warunkowały przebieg procesu dydaktycznego? Jaką rolę emocje odgrywały w relacjach nauczyciel-uczeń? Jak młodzież oceniała nauczycieli przejawiających określone emocje? Do przedstawienia powyższych zagadnień posłużono się literaturą pamiętnikarską autorstwa uczniów i nauczycieli z zaboru austriackiego.
\end{abstract}

Słowa kluczowe: emocje, literatura pamiętnikarska, nauczyciel, wartości, proces nauczania i wychowania, relacje nauczyciel-uczeń

\section{Rozważania wstępne}

Współcześnie zauważyć można wzrost zainteresowania emocjami oraz procesami emocjonalnymi w obszarze nauk psychologicznych, społecznych, historycznych, a także pedagogicznych. Szczególnie problematyka ta zaczyna być doceniana i coraz częściej staje się przedmiotem analizy w pedagogice, w której dotychczas zajmowała marginalną pozycję. Jest to jednak niezwykle znaczące zagadnienie w tym obszarze, ponieważ emocje wpisane są w codzienność zawodową nauczycieli, stanowiąc nieodłączny element ich pracy. W podejmowanych rozważaniach skoncentrowano się na ich ukazaniu, w szczególności zaś zwrócono uwagę na następujące kwestie: w jakim zakresie emocje nauczyciela warunkowały przebieg procesu dydaktycznego? Jaką rolę

* Dr Dorota Grabowska-Pieńkosz - absolwentka pedagogiki i historii na UMK w Toruniu, doktor nauk społecznych z zakresu pedagogiki, adiunkt w Katedrze Historii Myśli Pedagogicznej na Wydziale Nauk Pedagogicznych UMK, członek Towarzystwa Historii Edukacji. 
emocje odgrywały w relacjach nauczyciel-uczeń? Jak młodzież oceniała nauczycieli przejawiających określone emocje? Do przedstawienia powyższych zagadnień posłużono się literaturą pamiętnikarską autorstwa uczniów i nauczycieli z zaboru austriackiego. Niektóre z wykorzystanych tekstów autorzy pisali na bieżąco (dzienniki, listy), lecz większość powstała po wielu latach od zakończenia przez nich edukacji (pamiętniki sensu stricto, wspomnienia, autobiografie). W artykule wykorzystano również opracowania poruszające problematykę dotyczącą emocji w zawodzie nauczyciela ${ }^{1}$.

Należy podkreślić, że współcześnie ważnym i dynamicznie rozwijającym się nurtem w historiografii stała się tzw. „historia osobista”, która wynika z potrzeby postrzegania przeszłości z perspektywy indywidualnych losów ludzi uwikłanych w określone wydarzenia. Jak podkreślił historyk Marcin Kula, wiedza historyczna nie jest wyłącznie indywidualną własnością. W pewnym stopniu wszyscy jesteśmy twórcami historii - tworzymy ją (często na własny użytek), poza tym jesteśmy jej odbiorcami i popularyzatorami ${ }^{2}$. Podmiotem doświadczenia dziejów jest zawsze człowiek. Utrwalone przez niego indywidualne losy pozwalają odbiorcy na poznawanie i „doświadczanie” przeszłości, na bezpośrednie zbliżanie się do niej, na poznanie jej realiów, obyczajów, tradycji czy kultury. Wartość źródeł pamiętnikarskich wynika zatem z możliwości poznania opisów, które są swoistym świadectwem kultury nie tylko materialnej, lecz przede wszystkim duchowej. To dzięki niej odbiorca może poznać i zrozumieć mentalność osób żyjących w danym okresie historycznym. Tym samym źródła pamiętnikarskie pełnią rolę czynnika kulturotwórczego w procesie przekazywania tradycji, a zarazem przyczyniają się do umacniania więzi społecznych, a w szczególności do trwania społeczeństwa ${ }^{3}$.

\section{Emocjonalne uwarunkowania procesu dydaktycznego}

W pracy nauczyciela pojawia się wiele zróżnicowanych emocji, które w różnym zakresie determinują proces nauczania i uczenia się wychowanków. Z zapisków pamiętnikarskich wynika, że niektórzy z nauczających w szkołach zaboru austriackie-

${ }^{1}$ Bliżej emocji, red. A. Błachnio, A. Gózik, Lublin 2007; E. Dylan, Emocje. Naukowo o uczuciach, Poznań 2002; A. R. Hochschild, Zarządzanie emocjami. Komercjalizacja ludzkich uczuć, Warszawa 2009; Emocja - subiektywne doświadczenie czy zdarzenie interpersonalne: problematyka emocji w perspektywie różnych dziedzin nauki, K. Kaliszewska (red.), Poznań 2004; A. Jasielska, Charakterystyka i konsekwencje potocznego rozumienia emocji, Poznań 2013; K. Knopp, Inteligencja emocjonalna oraz możliwości jej rozwijania u dzieci i młodzieży, Warszawa 2010; J. Madalińska-Michalak, R. Góralska, Kompetencje emocjonalne nauczyciela, Warszawa 2012; Natura emocji: podstawowe zagadnienia, P. Ekman, R. J. Davidson (red.), Sopot 2012; Zrozumieć emocje, K. Oatley, J. M. Jenkins (red.), Warszawa 2005.

2 M. Kula, Nośniki pamięci historycznej, Warszawa 2002, s. 32-33.

${ }^{3}$ Szerzej: D. Grabowska, Wartość literatury pamiętnikarskiej w badaniach pedeutologii historycznej, [w:] W. Szulakiewicz (red.), Badania historyczne w pedagogice. Konteksty źródłowe, Toruń 2015, s. 53-76. 
go wzbudzali wśród uczniów zachwyt, a nawet zdumienie, ze względu na posiadaną wiedzę, a także umiejętności dydaktyczne związane z ożywionym, entuzjastycznym przekazywaniem wiadomości. Niewątpliwie takich pedagogów na swojej drodze edukacyjnej spotkali: Jadwiga Sikorska-Klemensiewiczowa, Michał Siedlecki, Stanisław Lam, Henryk Opieński i Kazimierz Chłędowski. Na początku odwołano się do wspomnień farmaceutki, a zarazem - co warto zaznaczyć - jednej z pierwszych studentek w historii polskiego szkolnictwa wyższego, J. Sikorskiej-Klemensiewiczowej. Zafascynowała się ona zasobem wiedzy i sposobem prowadzenia zajęć z fizyki doświadczalnej przez prof. Augusta Witkowskiego na Uniwersytecie Jagiellońskim. W szczególności podkreśliła, że potrafił on w przystępnej formie przekazywać informacje poprzez ukazywanie „nowych horyzontów” i ciekawe demonstrowanie różnych doświadczeń ${ }^{4}$. Warto dodać, że zadowolona była ona również z postawy innego uczonego z tej uczelni, profesora chemii Karola Olszewskiego. Jej zdaniem podczas wykładów prezentował on w nadzwyczajny i zdumiewający sposób przyrządy, które następnie wykorzystywał do przeprowadzania różnorodnych eksperymentów ${ }^{5}$. W ten sposób wzbudzał ogromne zainteresowanie prezentowaną tematyką wśród studentów. Z literatury pamiętnikarskiej dowiadujemy się, że także zasłużony przyrodnik M. Siedlecki, uczestnicząc w zajęciach K. Olszewskiego, zachwycił się jego wykładami, a w szczególności przeprowadzanymi przez niego doświadczeniami chemicznymi. Wspominał, że w konsekwencji postawa profesora wpłynęła na jego zainteresowania; pisał: zaraz na pierwszym roku studiów zapaliłem się do tego działu i miałem ochotę stale chemii się poświęcić.

Z ogromnym uznaniem i szacunkiem swoich nauczycieli wspominał znany krytyk i historyk literatury S. Lam. W szczególności docenił on postawę historyka Józefa Drzewickiego, którego spotkał na swojej drodze edukacyjnej podczas pobierania nauki w niższym gimnazjum w Sanoku. W prowadzonych wykładach poświeconych historii państw zaborczych nauczyciel starał się przekazać jak najwięcej informacji na temat dziejów państwa polskiego, których wykładanie było wówczas zakazane. Na wielu lekcjach przywoływał takich królów Polski jak: Bolesław Chrobry, Kazimierz Wielki, Bolesław Śmiały, Kazimierz Jagiellończyk, a także Stefan Batory. Ten trud został doceniony przez wychowanków. Jeden z nich - Jan Stapiński podkreślił, że pedagog ten przekazywał wiedzę z takim entuzjazmem, że $i$ on sam często łzy wzruszenia ocierał $i$ wśród uczniów sporo nas bywało zapłakanych ${ }^{7}$.

${ }^{4}$ J. Sikorska-Klemensiewiczowa, Przebojem ku wiedzy. Wspomnienia jednej z pierwszych studentek krakowskich z XIX wieku, Wrocław - Warszawa - Kraków 1961, s. 237-238.

5 Tamże, s. 238.

${ }^{6}$ M. Siedlecki, Na drodze życia i myśli. Pisma pośmiertne uzupełnione wyciagami $z$ „Notatnika wojennego" Ewy Siedleckiej, Wrocław - Warszawa - Kraków 1966, s. 27.

7 J. Stapiński, Pamiętnik, do druku przyg., przedm. i przyp. opatrzył K. Dunin-Wąsowicz, Warszawa 1959, s. 179-180. 
Z kolei zasłużony kompozytor i muzykolog H. Opieński zachwycony był umiejętnościami dydaktycznymi matematyka Franciszka Jezierskiego. Jego zadaniem potrafił on zimny przedmiot wyłożyć i tak objaśnić, że zyskał wśród wielu z nas [uczniów] entuzjastów dla analityki i trygonometrii, całek, różniczek itp. ${ }^{8}$. Natomiast znany polityk i pisarz K. Chłędowski po latach docenił zajęcia prowadzone przez polonistę Zygmunta Sawczyńskiego w gimnazjum św. Anny w Krakowie. Otóż w zapisach pamiętnikarskich zwrócił uwagę, że potrafił on z ogromnym zaangażowaniem przekazywać wiedzę. W konsekwencji interesował młodzieńcze umysły wykładaną tematyką, co potwierdzają słowa wcześniej przywoływanego wychowanka, który podkreślił, że $z$ prawdziwym zajęciem stuchali go, gdy wyszedł na katedrę 9 .

W tym kontekście należy wspomnieć o tych pedagogach, którzy w trosce o edukację uczniów zadbali o zbudowanie atmosfery sprzyjającej nauce. W pozytywnych słowach wspominani byli tacy nauczyciele, którzy potrafili w przyjaznym nastroju przekazywać wiedzę. W szczególności młodzież ceniła wychowawców radosnych, wesołych, posiadających poczucie humoru. O miłej atmosferze podczas zajęć z języka niemieckiego pisał M. Porwit. Jego germanista z gorlickiego gimnazjum - Mrozowski - był osobą o radosnym i pogodnym usposobieniu ${ }^{10}$. Również nauczyciele z gimnazjum św. Anny potrafili przekazywać wiedzę w przyjemny sposób. Wśród wielu zachowanych wspomnień można przywołać te spisane m.in. przez filologów klasycznych: Michała Boguckiego ${ }^{11}$, Michała Figla ${ }^{12}$, Jana Czubka ${ }^{13}$, polonistę Wincentego Srokę ${ }^{14}$ czy katechetę ks. Józefa Bilczewskiego, którego zdaniem ucznia Karola Korty cechowała nadzwyczajna dobroć serca, doskonała umiejętność obcowania $z$ ludźmi $i^{15}$.

Jak wcześniej wskazano, poczucie humoru pedagogów wpływało na atmosferę podczas zajęć, a tym samym warunkowało przebieg procesu dydaktycznego. W szczególności z życzliwością wspomniano takich nauczycieli, którzy potrafili zbudować przyjazne warunki do nauki. W kolejnych źródłach pamiętnikarskich wymieniono wiele nazwisk takich pedagogów. Świtalski, mimo sędziwego wieku i poważnego usposobienie lubił czasami podczas lekcji opowiedzieć jakąś wesołą historię. Potrafił nawet żartować $\mathrm{z}$ osób mu najbliższych, także ze swojej żony ${ }^{16}$. Humoru w cza-

8 J. Opieński, Wiązanka wspomnień z lat szkolnych 1875-1882 w Gimnazjum św. Anny im. Bartłomieja Nowodworskiego w 350-lecie tej krakowskiej szkoły średniej (1588-1938), [w:] Pót wieku wspomnień uczniów Gimnazjum im. B. Nowodworskiego (św. Anny) w Krakowie, Kraków 1938, s. 24.

${ }^{9}$ K. Chłędowski, Pamiętniki, Kraków 1957, T. 1, s. 100.

${ }_{10}$ M. Porwit, Spojrzenie poprzez moje życie, Warszawa 1986, s. 42.

${ }^{11}$ W. Błachut, Jak uczono greki w Kolegium B. Nowodworskiego?, [w:] Pót wieku wspomnień uczniów..., dz. cyt., s. 238-239.

${ }^{12}$ K. Piwarski, Lata wojny w szkole, [w:] Pół wieku wspomnień uczniów..., dz. cyt., s. 229.

${ }_{13}$ A. E. Balicki, My i Oni, [w:] Pół wieku wspomnień uczniów..., dz. cyt., s. 71.

${ }^{14}$ K. Korta, Gimnazjum św. Anny w Krakowie. Wspomnienia ucznia z lat 1888-1896, Kraków 1938, s. 66.

15 Tamże, s. 49.

${ }^{16}$ Rkps-UJ, sygn. 9824, Ludwik Kasprzyk, Wspomnienia, s. 41-42. 
sie zajęć nie szczędził również nauczyciel historii Michał Chyliński ${ }^{17}$. Z kolei Marian Chmielowiec, przywołując jednego z nauczycieli gimnazjalnych - Jana Czubka, pisał: żarty $i$ anegdoty płynace $z$ pogody i dobroci ducha profesorskiego wywoływały $w$ klasie tak niebywałe okrzyki: z czasem i my nowicjusze zaczynaliśmy »ryczeć" z reszta audytorium $^{18}$. Pedagog ten opowiadał dowcipy, aby pobudzić przemęczone umysły uczniów, zwłaszcza kiedy jego zajęcia przypadały na czwartą lub piątą godzinę lekcyjną ${ }^{19}$. Warto wspomnieć, że miła atmosfera sprzyjała generowaniu pomysłów oraz otwartości w dzieleniu się poglądami, czego doświadczyła i co doceniła H. Radlińska. W Listach... zaznaczyła, że zajęcia, w których uczestniczyła na Uniwersytecie Jagiellońskim, odbywały się w gronie koleżeńskim, co nadawało im wielki urok ${ }^{20}$.

Zdaniem uczniów galicyjskich wartość pracy nauczycielskiej obniżały zachowania, którym towarzyszyły takie emocje jak zastraszanie, nerwowość czy złość. W celu zobrazowania znaczenia tych emocji w procesie dydaktycznym odwołano się do wspomnień zachowanych przez jednego z wychowanków gimnazjum św. Anny w Krakowie, a mianowicie Jakuba Zachemskiego. Zaznaczył on, że nauczyciel języków klasycznych Wojciech Rypel wzbudzał szczególnie strach wśród tych uczniów, którzy byli słabiej przygotowani do zajęć z języka łacińskiego i greckiego. Otóż wystarczyło młodzieży powiedzieć, że od września obejmuje jeden z tych przedmiotów prof. W. Rypel, a wszyscy uczniowie przychodzili po wakacjach z dobrze opanowanym materiałem językowym ${ }^{21}$. We wspomnieniach badacza literatury, Stanisława Pigonia, pojawia się polonista Tomasz Pawłowski, który swoim postępowaniem wzbudzał strach w uczniach, ponieważ przy byle jakiej okazji otwierał szeroko usta i krzyczał: A duszo. Siadaj! Dwója! ${ }^{22}$.

Zapamiętani zostali również pedagodzy, którzy bardzo szybko ulegali zdenerwowaniu i wobec dzieci stosowali przemoc fizyczną. Z nerwowego usposobienia znana była m.in. nauczycielka Balcerowa z limanowskiej szkoły. Według informacji zachowanych we wspomnieniach, gdy dziecko czegoś nie umiało, katowała go bez miłosierdzia. Nieraz gdy ją coś poruszyło, biła cała klasę ${ }^{23}$. W konsekwencji dzieci bardzo jej się bały i nie chciały chodzić do szkoły. Z kolei nauczyciel łaciny i greki Stanisław Jakub, mimo tego, że był dobrym i łagodnym człowiekiem, to ulegał zdenerwowaniu w sytuacjach bezradności wobec różnych niegrzecznych zachowań ze strony

17 S. Estreicher, Kilka wspomnień z lat szkolnych 1879-1887, [w:] Pół wieku wspomnień..., dz. cyt., s. 5.

18 M. Chmielowiec, Prof. Jan Czubek, [w:] Pół wieku wspomnień..., dz. cyt., s. 107.

19 S. Friedeker, Wspomnienie o prof. Czubku, [w:] Pół wieku wspomnień..., dz. cyt., s. 112.

${ }^{20}$ Rkps - Zakład Narodowy im. Ossolińskich we Wrocławiu, sygn. Akc. 62/03, Helena Radlińska: Listy o nauczaniu i pracy badawczej, s. 25-26.

21 J. Zachemski, Wspomnienia, [w:] Pół wieku wspomnień..., dz. cyt., s. 51.

22 S. Pigoń, Z Komborni w świat. Wspomnienia młodości, Warszawa 1984, s. 175-176.

23 W. Gawron, Wspomnienia z Limanowszczyzny, Warszawa 1986, s. 16. 
uczniów, którzy nie reagowali na jego polecenia ${ }^{24}$. W tym aspekcie należy także przywołać zachowanie księdza Bronisława Karakulskiego. Otóż szybko denerwował się, gdy wychowanek zrobił jakąś pomyłkę z zakresu teologii. W takich sytuacjach zazwyczaj wypadał spoza katedry, gramolit się na ławkę i młócił delikwenta pięściami po plecach krzyczac „Ty, heretyku, jak mogłeś zrobić taką obrazę boską!’25. Z porywczości i zmiennego humoru znany był także wychowawca gimnazjalny ucznia Andrzeja Józefczyka, ponieważ podczas lekcji oczekiwał od uczniów, aby odgadywali jego myśli, a w przeciwnym przypadku bardzo szybko wpadał w gniew ${ }^{26}$. Wybitny historyk kultury i oświaty Stanisław Łempicki na swojej drodze edukacyjnej spotkał dwóch nauczycieli nerwowego usposobienia: historyka Jana Friedberga i filologa Michała Jezienickiego. Ten pierwszy oczekiwał od uczniów ciszy podczas zajęć i zainteresowania wykładaną tematyką. W innych warunkach popadał w irytację, złościł się oraz używał niecenzuralnych słów. Wówczas w całej klasie zapadała cisza i wszystkich ogarniał lę $\mathrm{k}^{27}$. Pedagoga M. Jezienickiego również łatwo było wyprowadzić z równowagi. Jeśli wpadł w gniew, nagle robił się blady i stawał się groźny. Wówczas, według zachowanych wspomnień:

całe pęki piorunów spadały na delikwenta czy na całą klasę. Na szczęście straszna chmura szybko się rozpraszała, choć profesor drżał jeszcze, był blady i zwolna dopiero wracał do siebie. Wyładowywał się widocznie w takim gniewie, bo potem przychodziło dużo spokojnych $\mathrm{dni}^{28}$.

W tym aspekcie można też powołać refleksję Łempickiego, który zastanawiał się nad skutecznością takiego zachowania nauczycieli: czyż może uchodzić za dobrego pedagoga nauczyciel, którego się wszyscy boja i którego wybuchy irytacji oczekiwane sq przez młodziė̇ z bijacym trwożnie sercem? ${ }^{29}$.

\section{Emocje w relacjach nauczyciel-uczeń}

Efekty pracy nauczyciela uzależnione są w dużej mierze od jego relacji z wychowankiem. Jak słusznie zauważyła Emilia Badura, niezwykle ważne jest na ile pedagog potrafi wprowadzić do swojej pracy z uczniami osobiste zbliżenie i przyjazne wspót$\dot{z}$ ycie, oparte na osobistych kontaktach $z$ wychowankami ${ }^{30}$. Z zapisków pamiętnikar-

${ }^{24}$ J. Ciałowicz, Przed pótwieczem (Wspomnienia i refleksje), [w:] J. Stachowicz (red.), Księga pamiątkowa gimnazjum męskiego w Sanoku 1885-1958, Kraków 1958, s. 197.

${ }^{25}$ J. Brzuza, Wspomnienia z lat szkolnych 1896-1904, [w:] Szkoła charakterów: Księga Jubileuszowa I Gimnazjum i Liceum w Rzeszowie, oprac. Józef Świeboda, Rzeszów 1985, s. 44.

${ }^{26}$ A. Józefczyk, W szkołach małego miasteczka i w gimnazjum tarnowskim, [w:] Galicyjskie wspomnienia szkolne, do druku przygot., wstęp. i przyp. opatrzył A. Knot, Kraków 1955, s. 54.

27 S. Łempicki, Złote paski: wspomnienia ze szkoły galicyjskiej, Warszawa 1957, s. 36.

28 Tamże, s. 41.

29 Tamże, s. 72.

${ }^{30}$ E. Badura, Emocjonalne uwarunkowania autorytet nauczyciela, Warszawa 1981, s. 34. 
skich wynika, że niektórzy nauczyciele potrafili nawiązać bliższą wieź z młodzieżą. Do takich osób niewątpliwie należał filolog Wincenty Sroka. Dążył on do zbudowania z podopiecznymi przyjacielskiej relacji, opartej na wartości zaczerpniętej z twórczości Bronisława Trentowskiego: jeśli chcesz być kochanym, masz sam kochać. Między sercem a sercem rozwija się łatwo elektryczność $i$ ciepło płynie $z$ jednego serca $w$ drugie ${ }^{31}$. Również dla filologa klasycznego Leopolda Świerza ważna była bliska relacja z wychowankami. Na kartach pamiętnika jeden z jego uczniów podkreślił, że młodzież miłowat, aż do obłędu. Na każdym kroku dawał nam, młodym, dowody swej przychylności $i^{32}$. W ten sposób zaskarbił sobie sympatię i szacunek. Z kolei polski poeta i prozaik Kornel Makuszyński we wspomnieniach podkreślił, że:

nas uczono z miłością, z wielką miłością. Oby każdy dziś młodzieniec zaznał choć odrobiny tej miłości, którą nam oddawano w niezmiernej, niewyczerpanej ilości. Może wtedy głupi, przekorny, śmiesznie buńczuczny młodzieniaszek, słowem: małpa - nie umiał tego ocenić, ale dzisiaj przypominam sobie tę miłość ze łzami w zmęczonych oczach ${ }^{33}$.

W tym aspekcie warto także przywołać stwierdzenie jednego z wychowanków krakowskiego gimnazjów św. Anny, który zaznaczył, że stosunek naszych profesorów do nas był bardzo bliski, pełen serdeczności, uprzejmości, a nawet - och, nie do wiary! tkliwości. Szanowali w nas ludzi! $!^{34}$.

Należy także wspomnieć o pedagogach, którzy nawiązali przyjazne relacje z wychowankami. Celem egzemplifikacji można przywołać postawę polonisty ze złotowskiego gimnazjum - Zygmunta Polakowskiego, którego na drodze edukacyjnej spotkał Józef Błoński. Nauczyciel ten zaprzyjaźnił się z młodzieńcem. Po latach Błoński w następujących słowach opisywał tę relację:

jego stosunek do mnie ułożył się jak stosunek przyjaciela do przyjaciela i takim pozostał do końca życia. Gdyśmy byli uczniami, służył nam radą, pomagał książkami z własnej biblioteki. Wiadomości jakie miał ode mnie o wszystkim, co się działo w szkole, nigdy nie wykorzystywa ${ }^{35}$.

Nie sposób pominąć przyjacielskich relacji między ówczesnym studentem S. Lamem a profesorem Janem Kallenbachem. Młodzieniec podczas studiów pilnie uczęszczał na jego wykłady i skrupulatnie notował przekazywane treści. Szczególnie interesowała go tematyka związana z prasą na emigracji oraz z twórczością przedstawicieli polskiego romantyzmu: Stefana F. Garczyńskiego i Adama Mickiewicza. Lam wiele czasu poświęcał na czytanie pism polskiego wieszcza narodowego, przynosił jego książki także na zajęcia uniwersyteckie. Kiedy Kallenbach zauważył, że student

\footnotetext{
31 K. Korta, dz. cyt., s. 64.

32 J. Opieński, dz. cyt., s. 29-30.

33 K. Makuszyński, Kartki z kalendarza, Kraków 1956, s. 29.

34 A. E. Balicki, dz. cyt., s. 68.

35 J. Błoński, Pamiętnik 1891-1939, Kraków 1981, s. 38.
} 
rozczytuje się w dziełach Mickiewicza, zaproponował mu uczestniczenie w seminarium. Było to ogromne wyróżnienie, ponieważ profesor dotychczas nie zapraszał nikogo spośród studentów pierwszego roku na tego typu zajęcia. Od tego momentu Lam brał czynny udział w seminarium, wygłaszając referaty i koreferaty. W ten sposób zacieśniły się relacje z profesorem. Niejednokrotnie Lam odprowadzał swojego mistrza do domu, a po drodze dyskutowali na tematy literackie. Czasami był też proszony do domu profesora na popołudniowe rozmowy poznawcze przy herbacie ${ }^{36}$.

Z perspektywy lat warto też wspomnieć o przyjaźni, jaka zawiązała się miedzy profesorem Ignacym Chrzanowskim a jego ówczesnym uczniem Stanisławem Pigoniem. Otóż ten drugi w czasie pierwszych lat studiów zafascynowany był literaturą staropolską, jednak w momencie pojawienia się na Uniwersytecie Jagiellońskim nowego wykładowcy (Chrzanowskiego właśnie), postanowił zająć się twórczością Mickiewicza i pod kierunkiem wspomnianego profesora przygotował i obronił rozprawę doktorską poświęconą tej tematyce ${ }^{37}$. Później współpracował z Chrzanowskim przy wydaniu kolejnej książki, Do podstaw wychowania narodowego (Lwów 1920). Tak wspominał tę relację:

w ten sposób zadzierzgnęła się między mną a profesorem-przewodnikiem ściślejsza zażyłość. Umacniana niewyczerpaną jego serdecznością, utwierdzała się z latami i miała mi przynieść jego przyjaźń dozgonną, którą liczę między najdrożej dary mego życia ${ }^{38}$.

Świadectwem tej przyjaźni są zachowane listy, zawierające wiele informacji na temat kierunków podejmowanych badań naukowych, uniwersyteckiego środowiska polonistycznego czy imponderabiliów życia polskiego. Zostały one zebrane i wydane w pracy Mistrz i uczeń: korespondencja wzajemna (1914-1936) Ignacy Chrzanowski, Stanisław Pigoń.

Ze źródeł pamiętnikarskich wynika również, że dobre relacje między nauczycielami a wychowankami oparte były na życzliwości. Za przykład posłużyć mogą postawy kilku profesorów z sanockiego gimnazjum, m.in. Pytla, Bielaka, Popiołka i Felińskiego. Ich wychowanek Stanisław Rymarz wspominał, że zwłaszcza dwaj pierwsi okazywali mu niesłychanie wiele życzliwości ${ }^{39}$, dlatego nawet po zakończeniu edukacji w tej szkole nadal utrzymywał z nimi bliskie kontakty. Przepełniona życzliwością była także relacja katechety ks. A. Bystrzonowskiego z podopiecznymi. Dzięki pracy jaką włożył w wychowanie młodzieży, zyskał u niej poważanie i sympatię ${ }^{40}$. Na kartach pa-

36 S. Lam, Życie wśród wielu, przyg. do druku A. Lam, Warszawa 1968, s. 23.

37 S. Pigoń, Z Komborni w świat. Wspomnienia młodości, Warszawa 1984, s. 277.

38 Tamże, s. 280; Por. D. Grabowska, Miejsca i osoby w, pamięci”Stanisława Pigonia i ich wpływna zainteresowania literackie Uczonego, „Acta Universitatis Nicolai Copernici. Nauki Humanistyczno-Społeczne. Pedagogika” 2014 (XXX), s. 99-114.

39 S. Rymar, Moje lata w gimnazjum 1897-1905 (wyjątek z pamiętnika), [w:] Księga pamiątkowa gimnazjum męskiego..., dz. cyt., s. 166.

40 T. Długosz, Gimnazjum I w Krakowie 1906-1908, [w:] Pół wieku wspomnień..., dz. cyt., s. 125 
miętnika uczeń wspominał go w następujących słowach: kochany przez cała młodzież gimnazjalną katecheta i prefekt seminarium, którego taktowi, cierpliwości i roztropności gorace nasze młode głowy zawdzięczały ocalenie po zbyt jaskrawych poczynaniach ${ }^{41}$. Również podejście przyrodnika Władysława Kulczyńskiego do młodzieży przepełnione było życzliwością, dlatego uczniowie darzyli go ogromnym szacunkiem i wielką miłością ${ }^{42}$. Godna wspomnienia jest też postawa dyrektora gimnazjum św. Anny w Krakowie, Leona Kulczyńskiego, który zapamiętany został jako człowiek niezwykle przychylny uczniom. Na kartach źródeł pamiętnikarskich podkreślono, że posiadał on życzliwość dla wszystkich: dla młodzieży, profesorów i dla każdej innej osoby ${ }^{43}$. Życzliwość była także dla nauczyciela Jana Molina jedną z najważniejszych wartości, jakimi kierował się w pracy pedagogicznej ${ }^{44}$.

Wspomnienia dokumentują, że byli i tacy nauczyciele, którzy wzbudzali szacunek wśród uczniów swoim taktem, spokojem i opanowaniem. Takimi cechami wyróżniał się w gronie nauczycielskim jasielskiego gimnazjum historyk i geograf Władysław Węgrzyński. W szczególności zapamiętany został przez ucznia Józefa Stapińskiego, który z podziwem wspominał jego postawę względem młodzieży, która przepełniona była spokojem, powagą i ogromnym taktem, a dodatkowo pedagog nigdy się nie śmiał, ale i gniewem nie unosił, zawsze opanowany ${ }^{45}$. Wśród przywoływanych w spisanych wspomnieniach pedagogów pojawili się i tacy, który w relacjach z uczniami wyróżniali się cierpliwością wobec różnych zachowań i poglądów młodzieży. Taką postawę nauczycieli po wielu latach docenił Kornel Makuszyński w następujących słowach: któż by się trwożył profesora, z którym wiodło się dyskusje, czasem namiętne: młodość szumiała skrzydlatymi słowami, a cierpliwy filozof słuchał i odpierał napaść po koleżeńsku ${ }^{46}$.

Z dotychczasowych rozważań wynika, że niezwykle ważny element procesu wychowania szkolno-uniwersyteckiego stanowiła odpowiednia relacja między pedagogiem a wychowankiem. Uczniowie szczególnie cenili tych pedagogów, którzy kontakty z nimi opierali na takich wartościach, jak: miłość, życzliwość, serdeczność, spokój, takt i opanowanie, a przy tym traktowali ich podmiotowo, z zachowaniem godności. Niejednokrotnie taka postawa spotkała się z uznaniem, szacunkiem i sympatią wychowanków. Jednak źródła wspomnieniowe dowodzą, że czasami zdarzały się pewne odstępstwa, a młodzież oceniała postępowanie swoich wychowawców według własnych, zróżnicowanych kryteriów. Tym samym nie wszyscy pedagodzy potrafili zbudować przyjazne relacje z wychowankami, mimo tego, że przy wykonywaniu swojej

${ }^{41}$ W. Wicher, Wspomnienia, [w:] Pół wieku wspomnień..., dz. cyt., s. 161.

42 M. Siedlecki, s. 23.

${ }^{43}$ F. Bielak, Młodzi i starzy z przed lat trzydziestu, [w:] Pół wieku wspomnień..., dz. cyt., s. 177.

44 S. Estreicher, Kilka wspomnień z lat szkolnych 1879-1887, [w:] Pół wieku wspomnień..., dz. cyt., s. 9.

45 J. Stapiński, dz. cyt., s. 185.

${ }^{46}$ K. Makuszyński, dz. cyt., s. 29. 
pracy nauczycielskiej wykazywali wyżej opisane cechy. Jako przykład można przywołać wspomnienia na temat filologa Wiktora Hahna ${ }^{47}$. W źródłach odnotowano, że w kontaktach z uczniami był delikatny, nigdy nie używał przykrych i ostrych słów, nie ironizował, obdarowywał podopiecznych dobrym uśmiechem i był wyrozumiały, lecz jego wysiłki nie zostały docenione. Jeden z jego wychowanków zwrócił uwagę, że jako człowiek wielkiej dobroci i niezwykle wrażliwego serca kochał jednak młodzież i dawał jej dużo z siebie, choć się na tym często nie poznawała ${ }^{48}$.

Należy zwrócić uwagę na to, że oczywiście nie wszyscy nauczyciele wspominani w źródłach pamiętnikarskich dbali o zbudowanie przyjaznych relacji z wychowankami. Wśród takich pedagogów można przywołać m.in. fizyka Sobolewskiego, który zgodnie z zachowaną relacją pamiętnikarską nie uznawał żartów, nie miał poczucia humoru $i$ on jeden trzymał się $z$ daleka od nas ${ }^{49}$. Również bliższego kontaktu z młodzieżą nie chcieli nawiązać niektórzy nauczyciele ze szkoły w Brzeżanach, co w zapisanych wspomnieniach zaznaczył jeden z wychowanków tej placówki, Emil Dunikowski, pisząc: byli dla nas poza szkoła obcymi, nieprzystępnymi ludźmi, którzy nigdy nie raczyli się do nas zniżyćs0 . Z kolei Władysław Łuszczkiewicz, wykładowca w Szkole Sztuk Pięknych w Krakowie, traktował młodych ludzi ironicznie. W szczególności w pamiętniku ówczesnego studenta, późniejszego zasłużonego malarza, Juliana Fałata, zachowała się relacja o nieżyczliwości Łuszczkiewicza, który miał podważać jego wiedzę i zainteresowania ${ }^{51}$. Za kolejny przykład posłużyć może postawa filologa klasycznego Andrzej Klisieckiego, który nie potrafił zbudować przyjaznej relacji z uczniami, ponieważ był człowiekiem oschłym, surowym, wymagajacym, zamkniętym w sobie s2 $^{2}$

\section{Uwagi końcowe}

Z powyższych rozważań wynika, że emocje wpisane są w aktywność pedagogiczną nauczycieli. Pojawiają się w różnych sytuacjach dydaktycznych i wychowawczych oraz mają zróżnicowany charakter. Uwarunkowane są zarówno cechami osobowymi wychowawców, jak i zachowaniem wychowanków. Na podstawie literatury pamiętnikarskiej można stwierdzić, że nauczyciele ukazywali swoje emocje podczas przekazywania uczniom wiedzy, a tym samym wzbudzali w nich pewne uczucia. Szczególnie cenieni i szanowani byli ci pedagodzy, którzy potrafili zachwycić, zdumieć, a także za-

47 S. Łempicki, dz. cyt., s. 93.

48 M. Opałek, O Lwowie i mojej młodości: kartki z pamiętnika 1881-1901, opat. posłowiem J. Trzynadlowski, Wrocław 1987, s. 137.

49 Z. Solarzowa, Mój pamiętnik, Warszawa 1985, s. 95.

50 E. Dunikowski, Z tęczowych dni w szkołach brzeżańskich 1861-1873, [w:] Galicyjskie wspomnienia szkolne..., dz. cyt., s. 372.

51 J. Fałat, Pamiętnik, Katowice 1987, s. 54-55.

52 J. Błoński, Pamiętnik 1891-1939..., dz. cyt., s. 34. 
inspirować odbiorców wykładaną tematyką. Wśród nich niewątpliwie należy wymienić wychowawców, których na swojej drodze edukacyjnej spotkali m.in. J. Sikorska-Klemensiewiczowa, S. Lam czy K. Chłędowski. W pozytywnych słowach wychowankowie przywoływali również nauczycieli, którzy zadbali, aby proces dydaktyczny przebiegał w przyjemnej atmosferze. Wielu z nich w radosny, miły sposób zwracało się do uczniów, a niektórzy podczas zajęć przytaczali żartobliwe anegdoty. W takich warunkach przebiegały zajęcia, w których uczestniczyła przykładowo H. Radlińska czy wychowankowie gimnazjum św. Anny w Krakowie: K. Korta, K. Piwarski czy S. Estreicher. Dodatkowo emocje nauczyciela miały niezwykle ważne znaczenie w procesie budowania relacji z wychowankiem. Źródła pamiętnikarskie dokumentują, że młodzież ceniła tych pedagogów, którzy dążyli do nawiązywania bliskich, serdecznych, przyjaznych oraz życzliwych kontaktów. Stanowiły one podwaliny do wzajemnego zrozumienia, akceptacji, zarówno w szkole, jak i poza jej murami. Potwierdzeniem tego niech będą przyjaźnie, jakie zawiązywały się między uczniem a mistrzem, takie jak te między S. Lamem a J. Kallenbachem czy S. Pigoniem a I. Chrzanowskim.

Uczniowie we wspomnieniach przywoływali także tych pedagogów, których cechy emocjonalne miały niekorzystny wpływ na procesy dydaktyczno-wychowawcze. Zazwyczaj łatwo ulegali oni zdenerwowaniu, często popadali w złość i gniew, a także zastraszali wychowanków. W ten sposób zniechęcali ich do dalszej nauki. Powyższe słowa znajdują odzwierciedlenie na kartach prac pamiętnikarskich m.in. wybitnego malarza J. Fałata czy znanego historyka oświaty S. Łempickiego.

\section{Bibliografia}

Badura E., Emocjonalne uwarunkowania autorytet nauczyciela, Wydawnictwo Szkolne i Pedagogiczne, Warszawa 1981.

Balicki A. E., My i Oni, [w:] Pół wieku wspomnień uczniów Gimnazjum im. B. Nowodworskiego (św. Anny) w Krakowie, Wydawnictwo Jubileuszu Gimnazjum im. B. Nowodworskiego, Kraków 1938, s. 64-86.

Bliżej emocji, A. Błachnio, A. Gózik (red.), Wydawnictwo Katolickiego Uniwersytetu Lubelskiego, Lublin 2007.

Bielak F., Młodzi i starzy z przed lat trzydziestu, [w:] Pół wieku wspomnień uczniów Gimnazjum im. B. Nowodworskiego (św. Anny) w Krakowie, Wydawnictwo Jubileuszu Gimnazjum im. B. Nowodworskiego, Kraków 1938, s. 169-178.

Błachut W., Jak uczono greki w Kolegium B. Nowodworskiego?, [w:] Pół wieku wspomnień uczniów Gimnazjum im. B. Nowodworskiego (św. Anny) w Krakowie, Wydawnictwo Jubileuszu Gimnazjum im. B. Nowodworskiego, Kraków 1938, s. 237-239.

Błoński J., Pamiętnik 1891-1939, Wydawnictwo Literackie, Kraków 1981. 
Brzuza J., Wspomnienia z lat szkolnych 1896-1904, [w:] Szkoła charakterów: Księga Jubileuszowa I Gimnazjum i Liceum w Rzeszowie, oprac. Józef Świeboda, Komitet przy I Liceum Ogólnokształcącym im. Stanisława Konarskiego, Rzeszów 1985, s. 43-48.

Chłędowski K., Pamiętniki, T. 1, Wydawnictwo Literackie, Kraków 1957.

Chmielowiec M., Prof. Jan Czubek, [w:] Pół wieku wspomnień uczniów Gimnazjum im. B. Nowodworskiego (św. Anny) w Krakowie, Wydawnictwo Jubileuszu Gimnazjum im. B. Nowodworskiego, Kraków 1938, s. 105-108.

Ciałowicz J., Przed półwieczem (Wspomnienia i refleksje), [w:] J. Stachowicz (red.), Ksiegga pamiątkowa gimnazjum męskiego w Sanoku 1885-1958, Państwowe Wydawnictwo Naukowe, Kraków 1958, s. 191-202.

Długosz T., Gimnazjum I w Krakowie 1906-1908, [w:] Pół wieku wspomnień uczniów Gimnazjum im. B. Nowodworskiego (św. Anny) w Krakowie, Wydawnictwo Jubileuszu Gimnazjum im. B. Nowodworskiego, Kraków 1938, s. 113-128.

Dunikowski E., Z tęczowych dni w szkołach brzeżańskich 1861-1873, [w:] Galicyjskie wspomnienia szkolne, do druku przygot., wstęp. i przyp. opatrzył A. Knot, Wydawnictwo Literackie, Kraków 1955, s. 345-382.

Dylan E., Emocje. Naukowo o uczuciach, Wydawnictwo Rebis, Poznań 2002.

Hochschild A. R., Zarządzanie emocjami. Komercjalizacja ludzkich uczuć, Wydawnictwo Naukowe PWN, Warszawa 2009.

Emocja - subiektywne doświadczenie czy zdarzenie interpersonalne: problematyka emocji w perspektywie różnych dziedzin nauki, K. Kaliszewska (red.), Bogucki Wydawnictwo Naukowe, Poznań 2004.

Estreicher S., Kilka wspomnień z lat szkolnych 1879-1887, [w:] Pół wieku wspomnień uczniów Gimnazjum im. B. Nowodworskiego (św. Anny) w Krakowie, Wydawnictwo Jubileuszu Gimnazjum im. B. Nowodworskiego, Kraków 1938, s. 1-20.

Fałat J., Pamiętnik, Śląski Instytut Naukowy, Katowice 1987.

Friedeker S., Wspomnienie o prof. Czubku, [w:] Pół wieku wspomnień uczniów Gimnazjum im. B. Nowodworskiego (św. Anny) w Krakowie, Wydawnictwo Jubileuszu Gimnazjum im. B. Nowodworskiego, Kraków 1938, s. 109-112.

Gawron W., Wspomnienia z Limanowszczyzny, Ludowa Spółdzielnia Wydawnicza, Warszawa 1986.

Grabowska D., Wartość literatury pamiętnikarskiej $w$ badaniach pedeutologii historycznej, [w:] W. Szulakiewicz (red.), Badania historyczne w pedagogice. Konteksty źródłowe, Wydawnictwo Naukowe Uniwersytetu Mikołaja Kopernika, Toruń 2015, s. 53-76.

Grabowska D., Miejsca i osoby w „pamięci” Stanisława Pigonia i ich wpływ na zainteresowania literackie Uczonego, „Acta Universitatis Nicolai Copernici. Nauki Humanistyczno-Społeczne. Pedagogika” 2014 (XXX), s. 99-114.

Jasielska A., Charakterystyka i konsekwencje potocznego rozumienia emocji, Wydawnictwo Naukowe UAM, Poznań 2013. 
Józefczyk A., W szkołach małego miasteczka i w gimnazjum tarnowskim, [w:] Galicyjskie wspomnienia szkolne, do druku przygot., wstęp. i przyp. opatrzył A. Knot, Wydawnictwo Literackie, Kraków 1955, s. 49-56.

Lam S., Życie wśród wielu, przygot. do druku A. Lam, Państwowy Instytut Wydawniczy, Warszawa 1968.

Łempicki S., Złote paski: wspomnienia ze szkoły galicyjskiej, „Wspólna Sprawa” - Wydawnictwa Oświatowe, Warszawa 1957.

Knopp K., Inteligencja emocjonalna oraz możliwości jej rozwijania u dzieci i młodzie$\dot{z} y$, Wydawnictwo Uniwersytetu Kardynała Stefana Wyszyńskiego, Warszawa 2010.

Korta K., Gimnazjum św. Anny w Krakowie. Wspomnienia ucznia z lat 1888-1896, Towarzystwo Miłośników Historii i Zabytków Krakowa, Kraków 1938.

Kula M., Nośniki pamięci historycznej, Wydawnictwo DiG, Warszawa 2002.

Madalińska-Michalak J., Góralska R., Kompetencje emocjonalne nauczyciela, ABC a Wolters Kluwer business, Warszawa 2012.

Makuszyński K., Kartki z kalendarza, Wydawnictwo Literackie, Kraków 1956.

Natura emocji: podstawowe zagadnienia, P. Ekman, R. J. Davidson (red.), Gdańskie Wydawnictwo Psychologiczne, Sopot 2012.

Opałek M., O Lwowie i mojej młodości: kartki z pamiętnika 1881-1901, opat. posłowiem J. Trzynadlowski, Zakład Narodowy im. Ossolińskich, Wrocław 1987.

Opieński J., Wiązanka wspomnień z lat szkolnych 1875-1882 w Gimnazjum św. Anny im. Bartłomieja Nowodworskiego w 350-lecie tej krakowskiej szkoły średniej (1588-1938), [w:] Pót wieku wspomnień uczniów Gimnazjum im. B. Nowodworskiego (św. Anny) w Krakowie, Wydawnictwo Jubileuszu Gimnazjum im. B. Nowodworskiego, Kraków 1938, s. 35-37.

Pigoń S., Z Komborni w świat. Wspomnienia młodości, Ludowa Spółdzielnia Wydawnicza, Warszawa 1984.

Piwarski K., Lata wojny w szkole, [w:] Pół wieku wspomnień uczniów Gimnazjum im. B. Nowodworskiego (św. Anny) w Krakowie, Wydawnictwo Jubileuszu Gimnazjum im. B. Nowodworskiego, Kraków 1938, s. 227-236.

Porwit M., Spojrzenie poprzez moje życie, Wydawnictwo Czytelnik, Warszawa 1986.

Rkps - UJ, sygn. 9824, Ludwik Kasprzyk, Wspomnienia.

Rkps - Zakład Narodowy im. Ossolińskich we Wrocławiu, sygn. Akc. 62/03, Helena Radlińska: Listy o nauczaniu i pracy badawczej.

Rymar S., Moje lata w gimnazjum 1897-1905 (wyjątek z pamiętnika), [w:] J. Stachowicz (red.), Księga pamiątkowa gimnazjum męskiego w Sanoku 1885-1958, Państwowe Wydawnictwo Naukowe, Kraków 1958, s. 162-170.

Siedlecki M., Na drodze życia i myśli. Pisma pośmiertne uzupetnione wyciagami z „Notatnika wojennego" Ewy Siedleckiej, Zakład Narodowy im. Ossolińskich, Wrocław - Warszawa - Kraków 1966. 
Sikorska-Klemensiewiczowa J., Przebojem ku wiedzy. Wspomnienia jednej z pierwszych studentek krakowskich $z$ XIX wieku, Zakład Narodowy im. Ossolińskich, Wrocław - Warszawa - Kraków 1961.

Solarzowa Z., Mój pamiętnik, Ludowa Spółdzielnia Wydawnicza, Warszawa 1985.

Stapiński J., Pamiętnik, do druku przyg., przedm. i przyp. opatrzył K. Dunin-Wąsowicz, Ludowa Spółdzielnia Wydawnicza, Warszawa 1959.

Wicher W., Wspomnienia, [w:] Pół wieku wspomnień uczniów Gimnazjum im. B. Nowodworskiego (św. Anny) w Krakowie, Wydawnictwo Jubileuszu Gimnazjum im. B. Nowodworskiego, Kraków 1938, s. 160-163.

Zachemski J., Wspomnienia, [w:] Pół wieku wspomnień uczniów Gimnazjum im. B. Nowodworskiego (św. Anny) w Krakowie, Wydawnictwo Jubileuszu Gimnazjum im. B. Nowodworskiego, Kraków 1938, s. 38-63.

Zrozumieć emocje, K. Oatley, J. M. Jenkins(red.), Wydawnictwo Naukowe PWN, Warszawa 2005.

\section{Emotions in the teacher's work in the sources memoir}

Abstract: The purpose of this article is to present the importance of emotions in pedagogical work, with particular emphasis on teaching and upbringing situations. Emotions are diverse in nature and are influenced by various factors - both personal characteristics of educators and the behavior of pupils. Therefore, in the article it was decided to show: To what extent did teacher's emotions determine the course of the teaching process? What role was played by the emotions in relations between teacher and pupils? How young people evaluate certain emotions manifested by teachers? To present these issues, author based the analysis on the memoirs literature written by students and teachers from the Austrian partition.

Keywords: emotions, memoirs literature, the teacher, the process of teaching and education, teacher-student relations

About the author: dr Dorota Grabowska-Pieńkosz - graduate in education and history at Nicolaus Copernicus University in Torun, a doctor of social pedagogy, assistant professor in the Department of History of Thought at the Faculty of Pedagogy of Pedagogical Sciences of the Nicolaus Copernicus University, a member of the Society for the History of Education. 


\author{
Małgorzata Kunicka* \\ Uniwersytet Szczeciński \\ mkunicka@op.pl
}

\title{
Władza i posłuszeństwo w procesie wychowania (na podstawie instrukcji Posługa władzy i posłuszeństwo) ${ }^{1}$
}

\begin{abstract}
Streszczenie: W „kulturze obfitości” wykreowanej w świecie liberalnych poglądów nie znajduje się miejsca na wychowanie dziecka w duchu posłuszeństwa. Apologeci permisywnego wychowania utożsamiają wolność człowieka z przesadną tolerancją, wyrugowaniem autorytaryzmu, ale też z odejściem od wychowania do posłuszeństwa. Istnieje jednak potrzeba wychowania młodego człowieka do odpowiedzialności, roztropności, rzetelności, poszanowania dla drugiego. Staje się to możliwe w sytuacji, gdy władza wychowawcza rozumiana jest jako posługa, a posłuszeństwo - jako ufne wsłuchiwanie się w głos wychowawcy.
\end{abstract}

Słowa kluczowe: wychowanie, autorytet, władza

\section{Wstęp}

Mądre wychowanie zawsze poszukuje najbardziej optymalnych relacji pomiędzy podmiotami; polega na skutecznym podziale zadań i odpowiedzialności pomiędzy wychowankiem a wychowawcą. Odejście od paradygmatu edukacji adaptacyjnej na rzecz podmiotowej, krytyczno-kreatywnej, oznaczało zmianę relacji wychowawcy

* Dr Małgorzata Kunicka - doktor nauk humanistycznych w zakresie pedagogiki, obecne miejsce pracy: Uniwersytet Szczeciński, Wydział Humanistyczny, Instytut Pedagogiki, Katedra Wczesnej Edukacji. Zainteresowania naukowe: pedagogika wczesnoszkolna, aksjologia, teleologia. Autorka monografii pedagogicznej pt. Temporalne orientacje teleologiczne nauczycieli oraz wielu artykułów naukowych w punktowanych czasopismach pedagogicznych, m.in. w: „Teraźniejszość - Człowiek Edukacja”, „Opuscula Sociologica”, „Forum Oświatowe”, „Kultura - Media - Teologia”, „Kultura i Wychowanie", a także szeregu publikacji w pracach zwartych (łącznie blisko 50 publikacji).

${ }^{1}$ Niektóre z tez artykułu zostały zaprezentowane podczas konferencji naukowej z cyklu Sprawności moralne w wychowaniu, Szczecin 2017. 
wobec wychowanka: „urabianie osobowości” zamieniono na „wspieranie rozwoju” z uwzględnieniem samostanowienia wychowanka. Wychowanie humanistyczne z wiodącymi cechami, jakimi są partnerstwo i dialog, w którym silnie podkreślane są podmiotowość, godność, autonomia i możliwość samorealizacji, wymusiło zmianę sposobów rozumienia władzy i posłuszeństwa wobec niej. Rozważania na temat wychowania należy poprzedzić definicyjnym krajobrazem pojęć. Kluczowe są tu: szacunek, autorytet, władza i posłuszeństwo, które analizowane będą z punktu widzenia pedagogiki katolickiej. Prezentowana perspektywa spojrzenia na wychowanie może wydawać się niepoprawnie czy zbyt odważnie jednostronna, jednak podjęta w artykule refleksja nad wciąż kontrowersyjnym zagadnieniem wychowania w duchu posłuszeństwa nie rości sobie prawa do przyjmowania uniwersalnego znaczenia, stanowić ma jedynie przyczynek do charakterystyki pedagogiki katolickiej i być w jej obrębie głosem w dyskusji.

\section{Posłuszeństwo}

Termin „posłuszeństwo” znaczeniowo mieści w sobie karność, posłuch, pokorę, zdyscyplinowanie, uznanie czyjegoś autorytetu. Ocena stopnia użyteczności tego terminu dla procesu wychowania zależy od przyjętego paradygmatu. Zwolennicy nurtów wolnościowych sądzą, że naturalnej ludzkiej predylekcji do posłuszeństwa towarzyszy dyspozycja do delegowania odpowiedzialności za własne decyzje i czyny, a posłuszeństwo wobec autorytetu może pozbawić jednostkę doświadczenia wolności i odpowiedzialności. Stąd na przeciwległym biegunie w stosunku do posłuszeństwa stawia się wolność, niezależność i samostanowienie. Marginalizowanie pojęcia posłuszeństwa w wychowaniu liberalnym staje naprzeciw poglądom wyznawanym przez przedstawicieli pedagogiki konserwatywnej, którzy uważają, że wychowanie dziecka w duchu posłuszeństwa służy dobru samego wychowanka, a posłuszeństwo jest dla niego umiejętnością rozpoznawania pozytywnej treści przedstawionych wskazań i życzeń cenionej przez wychowanka osoby oraz zdolnością do uznania i realizowania tych życzeń. Funkcjonowanie człowieka posłusznego jest efektem przyjęcia i zagospodarowania przez niego własnej wolności oraz świadomego zaangażowania na rzecz dobra z uwzględnieniem jego woli i rozumu. Takie czyny nie są niczym zdeterminowane, ograniczane ani wymuszane ${ }^{2}$. Posłuszeństwo potocznie kojarzone z podległością, zniewoleniem i ograniczeniem wolności zakłada bunt i opór podwładnych wobec dzierżących władzę. Negatywny stosunek do posłuszeństwa przejawiają niejednokrotnie sami wychowawcy, twierdząc, że oczekiwanie posłuszeństwa od podwładnych ogranicza ich swobodę, powoduje nieufność wobec przełożonych, zakłada

2 Szerzej piszę o tym w: M. Kunicka, Linguistic landscape wokół procesu wychowania. Archaizmy i eufemizmy jako enklawy językowe, „Teraźniejszość - Człowiek - Edukacja”, nr 1(65)/2014, s. $129-141$. 
bezwolność, zmusza do bezmyślności i prowadzi do wykreowania u wychowanków postaw podległości i niezdolności do emancypacyjnego oporu. Jednak w literaturze odróżnia się pojęcie posłuszeństwa od pojęcia uległości. Stanisław Sławiński pisze, że posłuszeństwo wyrasta $z$ wolności osoby, podczas gdy uległość jest wyrzeczeniem się wolności $i^{3}$. Posłuszeństwo posiada walor dobrowolności, zakłada uznanie zwierzchności i uprawnień decyzyjnych, które zawsze mogą zostać wypowiedziane i odwołane przez podlegającemu władzy. Oddanie siebie pod opiekę i troskę może pozostawać warunkowe i w wolnym wyborze może być uznawane bądź kwestionowane. Człowiek posłuszny, czyli dobrowolnie poddany pod wpływy sprawującego władzę, nie przestaje być wolny w wyborach, odpowiedzialny za siebie i swoje czyny, nie staje się bezwolny, bowiem w wolności wybiera troskę o siebie i dobro wspólne. Uznając autorytet sprawującego władzę, mając do niego szacunek i zaufanie, podwładny deleguje uprawnienia do dysponowania własną osobą i zobowiązuje się w wolnym wyborze do posłuszeństwa wobec przełożonego. Stanowią je dwie następujące po sobie czynności: wysłuchanie i działanie po słuchaniu. Pomiędzy tymi czynnościami znajduje się cała przestrzeń refleksji, krytycznej analizy i roztropnego zawierzenia wychowawcy. Posłuszeństwo nie jest synonimem uległości. Posłuszny jest dającym posłuch ze względu na szacunek, autorytet i zaufanie. Uległość pozostaje zaś zawsze skutkiem przeświadczenia, że nie ma możliwości wyboru, że należy wyrzec się własnej wolności i poddać się bezwolnie decyzjom przełożonego. Jest podporządkowaniem się innym ze względu na posiadane przez nich środki nacisku i przymusu; wypływa ze zniewolenia człowieka. Wewnętrzne ubezwłasnowolnienie spowodowane jest strachem i odczuwanym imperatywem podległości i podporządkowania. Posłuszeństwo udoskonala taką wolność, która jest przyjmowaniem postawy służby oraz nie jest panowaniem i dominacją. Nie jest ono zniewoleniem, lecz cnotą, która prowadzi do prawdziwej wolności. Jeśli bowiem autorytet rozumie się jako coś, co skłania do pewnego rodzaju posłuszeństwa, to jest to taka uległość, która - zdaniem Hannah Arendt - nie wyklucza wolności ${ }^{4}$.

\section{Władza}

Posłuszeństwo zawsze pozostaje w stosunku wobec władzy. Pojęcie władzy kojarzone bywa z przemocą, uciskiem, niezrozumieniem, wykorzystywaniem, niesprawiedliwością. Jest ona nieodzownym elementem życia społecznego, stąd konieczność uznania jej wszechobecności. Celem władzy jest m.in. podejmowanie decyzji dotyczących osób jej podlegających i ponoszenie za nie odpowiedzialności. Oznacza prawo i obowiązek decydowania, pełni funkcję regulacyjną i porządkującą, a więc

${ }^{3}$ S. Sławiński, Wychowywać do posłuszeństwa, Warszawa 1994, s. 54.

${ }^{4} \mathrm{H}$. Arendt, Między czasem minionym a przyszłym. Osiem ćwiczeń z myśli politycznej, Warszawa 1994, s. 109-174. 
rolę służebną, wobec grupy społecznej. Od sposobu rozumienia władzy (jako służby lub jako panowania) zależy właściwe rozumienie posłuszeństwa wobec niej. Pozyskać władzę można co najmniej na pięć sposobów:

1) przyznanie jej samemu sobie - np. lider grupy rówieśniczej;

2) z nominacji - np. mianowany kierownik zespołu;

3) poprzez wybory - np. prezydent miasta;

4) narzucenie siłą - np. przywódca w systemie totalitarnym;

5) z porządku naturalnego - np. rodzice ${ }^{5}$.

Posłuszeństwo jako wolny wybór i poddanie się decyzjom władzy jest możliwe w pierwszych trzech przypadkach, w czwartym należy mówić o uległości lub oporze wobec władzy. Szczególny rodzaj posłuszeństwa występuje wobec władzy rodzicielskiej, której zakres w miarę upływu czasu stale się zmniejsza. Władza rodzicielska jest częścią władzy wychowawczej, którą sprawują, obok rodziców, nauczyciele i wychowawcy. Władza wychowawcy i posłuszeństwo wychowanka nie są oddzielnymi lub przeciwstawnymi stanami rzeczy, ale raczej dwoma wymiarami tej samej rzeczywistości. Mądrość wychowania polega m.in. na kształtowaniu kultury wzajemnego szacunku. Obdarzając nim wychowawcę, dziecko respektuje jego autorytet i w sposób wolny, bez przymusu, wybiera wobec niego posłuszeństwo. Wychowanie do posłuszeństwa to dążenie, aby miejsce wymuszonej uległości zajmowało stopniowo coraz bardziej świadome posłuszeństwo dziecka $a^{6}$, celem władzy wychowawczej jest wspieranie rozwoju wychowanków. Rodzice małego dziecka nie muszą zabiegać o swój autorytet, czyli szacunek, poważanie i zaufanie, ponieważ dziecko bezkrytycznie obdarza nim swoich rodziców. Zanim będzie można oczekiwać szacunku starszego dziecka wobec dorosłego, wcześniej należy nim obdarzyć wychowanka. Podstawą działania wychowawczego jest poszanowanie godności dziecka i respektowanie jego praw, co - jak pisze Sławiński - określa granice inicjatywy wychowawczej dorosłych ${ }^{7}$. Szacunek wobec małego człowieka warunkuje dobre relacje z wychowawcą i daje szansę na uznanie przez dziecko jego autorytetu. Szacunek wobec dziecka - według Sławińskiego - zakłada:

1) nietykalność osobistą, także w aspekcie używanego słownictwa;

2) poważny sposób traktowania dziecka podczas rozmowy, tj. prawdomówność, dotrzymywanie słowa, dochowywanie tajemnic;

3) stawianie wysokich i realnych wymagań;

4) podmiotowe traktowanie;

5) respektowanie odrębności i autonomii ${ }^{8}$.

Iwona Jazukiewicz uznaje, że uczeń okazuje szacunek nauczycielowi wtedy, gdy nie krytykuje go, broni jego racji i wartości, nie zwraca mu uwagi w obecności innych

\footnotetext{
5 S. Sławiński, dz. cyt., s. 50-51.

6 Tamże, s. 76.

7 Tamże, s. 27.

8 Tamże, s. 27-30.
} 
osób, mówi mu prawdę oraz dotrzymuje danego słowa9. Janusz Korczak w swoich ideałach wychowawczych kładł nacisk na kilka kategorii: szacunek dla ucznia, wzajemne zaufanie między uczniem a nauczycielem, miłość dziecka, a także dialog między opiekunem, wychowawcą, nauczycielem a dzieckiem ${ }^{10}$. Korczak żądał szacunku dla przeszłości dziecka, dla jego niewiedzy, dla własności ucznia i jego budżetu, dla bieżącej godziny, dla dnia dzisiejszego, dla jego tajemnic i tęsknot. Szacunku dla każdej z osobna chwili, bo umrze i nigdy się nie powtórzy, a zawsze na serio skaleczona krwawić będzie, zamordowana płoszyć upiorem złych wspomnień ${ }^{11}$. Znaczenie szacunku wobec dziecka jest również podkreślane w ponadczasowej, także dziś popularnej, pedagogice Marii Montesorii. Obok uwzględniania właściwości rozwojowych dziecka, jego możliwości, potrzeb i zainteresowań; indywidualizacji kształcenia; oparcia procesu kształcenia na aktywności wychowanka oraz stymulowania rozwoju dziecka we wszystkich sferach osobowości, szacunek dla dziecka wskazywany jest jako kluczowy element jej pedagogiki.

\section{Autorytet}

Tylko poprzez poszanowanie autorytetu i kulturę szacunku można stać się osobami wpływu i autorytetu. Jednym z zasadniczych praw człowieka jest prawo szacunku wobec osób w pozycji autorytetu. Domaganie się szacunku względem wychowawcy, przełożonego lub tego, który dzierży władzę staje się bezprzedmiotowe w sytuacji, w której władza jest nadużywana, a posłuszeństwo przeradza się w uległość. Erich Fromm wyróżnia dwa rodzaje autorytetów: 1) autorytet racjonalny, wspierający rozwój, wpływający na zachowania innych bez używania przemocy i opresji, oraz 2) autorytet irracjonalny, wytworzony w oparciu o władzę, często destrukcyjny dla podporządkowanych mu, wykorzystujący uległość, opresyjny ${ }^{12}$. Autorytet racjonalny jest akceptowany przez podlegających mu z racji tego, że podległość tę uważają za słuszną. Jego celem jest to, by inni chcieli mu dorównać. Autorytet irracjonalny ma natomiast wpływ na innych nie przez wzgląd na swoje kompetencje, lecz ze względu na siłę wpływu wynikającą $\mathrm{z}$ ustanowionego stosunku społecznego dającego mu przewagę nad innymi. Władza rodzicielska łączy oba typy autorytetów. Jest oczywiste, że rodzice powinni oczekiwać posłuszeństwa dziecka opartego na racjonalnych przesłankach, jednak bywa, że ze względu na dobro dziecka rodzice wymagają jego uległości z powodu braku umiejętności oceniania i wartościowania. Dzieje się tak aż do momentu zinterioryzowania przez dziecko norm i wartości, co przebiega

${ }^{9}$ I. Jazukiewicz, O szacunku, http://www.edukacyjne.dyskursy.univ.szczecin.pl/szacunku.htm (dostęp: 01.03.2017).

10 Z. Jasiński, Zaufanie w pedagogice Janusza Korczaka, [w:] J. Bińczycka (red.), Korczakowskie dialogi, Warszawa 1999, s. 103.

${ }_{11}$ Tamże, s. 114.

12 E. Fromm, Mieć czy być, Poznań 1995, s. 83. 
zgodnie z koncepcją Piageta, który wyróżnił dwa etapy rozwoju moralnego dziecka: 1) etap heteronomii, czyli podporządkowania się autorytetom, przyjmowania norm ze względu na posłuszeństwo; 2) etap autonomii, w którym następuje internalizacja norm i przyjmowanie zasad nie ze względu na nakazy dorosłych, lecz jako efekt samodzielnych wyborów. W budowaniu autorytetu racjonalnego kluczowym jest spójność słów i czynów, sprawiedliwość i konsekwencja, stałe, niezmienne zasady, stała obecność, oraz przede wszystkim wzajemny szacunek.

Sławomir Pasikowski zauważa, że posłuszeństwo wobec autorytetu stanowi powszechną normę społeczną i uznawane jest za jeden z silniejszych czynników sytuacyjnych indywidualnego zachowania.

W kontekście praktyki edukacyjnej, w którym posłuszeństwo bywa pożądane, wymagane i traktowane jako cel edukacyjnych oddziaływań, promowana winna być idea refleksyjności i krytyczności oraz potrzeba poszukiwania środków zwiększających zdolność dystansowania się do autorytarnych czy autorytatywnych przekazów i wymagań ${ }^{13}$.

\section{Posłuszeństwo, władza i autorytet - narracja teologiczna}

Z perspektywy teologicznego oglądu rzeczywistości, pojęcia władzy i posłuszeństwa, także szacunku i autorytetu, nabierają nowych znaczeń. Warto przyjrzeć się tym znaczeniom w aspekcie życia konsekrowanego i odnieść je wprost do władzy wychowawczej oraz posłuszeństwa dzieci i młodzieży wobec wychowawców. Kongregacja ds. Instytutów Życia Konsekrowanego i Stowarzyszeń Życia Apostolskiego opublikowała 11 maja 2008 r. instrukcję zatytułowaną Posługa władzy i posłuszeństwo. Dokument zaprezentowano 28 maja 2008 r. na dorocznym spotkaniu Konferencji Przełożonych Generalnych, które odbywa się w Rzymie. Instrukcja ukazała się w głównych językach zachodnich ${ }^{14}$. W niedługim czasie ukazał się także jej polski przekład. W dokumencie zwraca się uwagę na fakt, że w ostatnich latach zmienił się sposób odczuwania i przeżywania władzy i posłuszeństwa nie tylko w Kościele, ale także w całym społeczeństwie. Zmiany te wyniknęły z głębszej świadomości wartości każdej osoby - świadomości wolności i zdolności nawiązywania relacji - oraz z mniej indywidualistycznego sposobu rozumienia misji/posługi władzy na rzecz współodpo-

${ }^{13}$ S. Pasikowski, Postuszeństwo wobec autorytetu nauczyciela w sytuacji wcześniejszego wzbudzania lub redukowania indywidualnego poczucia władzy, „Kultura i Edukacja”, nr 4 (90)/2012, s. 38; https://depot.ceon.pl/bitstream/handle/123456789/8871/Pasikowski S. Pos\%C5\%82uszenstwo wobec\%20autorytetu nauczyciela.pdf? sequence=1\&isAllowed=y (dostęp: 01.03.2017).

${ }_{14}$ Tekst Instrukcji został umieszczony na internetowej stronie Watykanu: www.vatican.va. Tekst polski: Kongregacja ds. Instytutów Życia Konsekrowanego i Stowarzyszeń Życia Apostolskiego, Faciem tuam, Domine requiram. Instrukcja O posłudze władzy i posłuszeństwie, Watykan 2008. 
wiedzialności i współdzielenia się władzą ${ }^{15}$. Instrukcja mówi z jednej strony o trudnym posłuszeństwie, a z drugiej strony o trudnym spełnianiu posługi władzy, ukazując zarówno posłuszeństwo, jak i władzę jako służenie sobie nawzajem. Powstaje zatem pytanie, czy można na relacje wychowawca - wychowanek spojrzeć w analogiczny sposób jak na relacje przełożony - podwładny w życiu konsekrowanym? Wydaje się, że jest to możliwe w sytuacji uznania, że: 1) władza jest posługą, czyli pełniący ją jest sługą wobec tych, którzy mu podlegają; 2) władza jest po to, by zapewnić rozwój, wspierać i promować godność osoby, by w trudnościach wzbudzać nadzieję, towarzyszyć na drodze rozwoju; 3) władza przełożonego zawsze pozostaje w służbie wobec podwładnego, pełni posługę wobec niego, troszczy się o dobro podległych mu osób; 4) zadaniem wychowawcy, w ręku którego spoczywa władza wobec wychowanków, jest budzenie zmysłu krytycznego i uczenie dokonywania samodzielnych wyborów. Zestawienie rozumienia władzy przełożonego i posłuszeństwa podwładnego w procesie formacji życia konsekrowanego na podstawie Instrukcji Posłuszeństwo i posługa władzy ze sposobem podejścia do władzy rodzicielskiej/wychowawczej i posłuszeństwie dziecka w procesie wychowania przedstawia tabela 1.

W oparciu o instrukcję Posługa władzy i posłuszeństwo Czesław Parzyszek podkreśla, że cechą współczesnego świata jest m.in. wrażliwość na wolność: człowiek jest wolny dopóki nie pojawia się wymaganie zasad moralnych, które ograniczają wolność. W tym kontekście Parzyszek zwraca uwagę na fakt, że wolność jest podporzadkowaniem sie prawdzie, a nie podporządkowaniem prawdy sobie ${ }^{16}$. Inne cechy współczesnego świata, które mają wpływ na zmianę przeżywania posłuszeństwa oraz doświadczenia sprawowania władzy, wymienione przez Parzyszka to: 1) otwartość świata, 2) obecność i tempo zmian, 3) kultura obfitości i doskonałości wytworów $\mathrm{w}$ miejsce osobo centryzmu, 3) rozluźnienie więzi międzyludzkich w obliczu wizji totalnego zniszczenia, 4) zjawisko desakralizacji, 5) selektywny dobór norm i wyrugowanie chrześcijaństwa z przestrzeni publicznej, 6) relatywizm moralny ${ }^{17}$. W takim świecie pojawia się ogromna trudność w zrozumieniu i akceptacji posłuszeństwa oraz strach i obawa przed posługą władzy.

${ }_{15}$ W. Barszcz, Watykan: instrukcja o zakonnej władzy i postuszeństwie, http://kosciol.wiara.pl/ doc/494251. Watykan-Instrukcja-o-zakonnej-wladzy-i-posluszenstwie (dostęp: 01.03.2017).

${ }^{16}$ Cz. Parzyszek, Posłuszeństwo i posługa władzy - odpowiedzia na zagrożenia współczesnej cywilizacji, „Warszawskie Studia Pastoralne”, nr 9/2009, s. 93. http://mazowsze.hist.pl/27/Warszawskie Studia Pastoralne/625/2009/22612/ (dostęp: 01.03.2017).

17 Tamże, s. 92-94. 
Tabela 1. Zestawienie rozumienia władzy przełożonego i posłuszeństwa podwładnego w procesie formacji życia konsekrowanego na podstawie Instrukcji Posłuszeństwo i posługa władzy ze sposobem podejścia do władzy rodzicielskiej/wychowawczej i posłuszeństwie dziecka w procesie wychowania ${ }^{18}$

\begin{tabular}{|c|c|}
\hline $\begin{array}{l}\text { Władza przełożonego i posłuszeństwo podwładnego } \\
\qquad \text { w procesie formowania }\end{array}$ & $\begin{array}{l}\text { Władza rodzicielska/wychowawcza i posłuszeństwo } \\
\text { dziecka w procesie wychowania }\end{array}$ \\
\hline \multicolumn{2}{|c|}{ POSŁUSZEŃSTWO JAKO WSŁUCHIWANIE SIĘ } \\
\hline $\begin{array}{l}\text { Postuszeństwo jest przede wszystkim postawa } \\
\text { synowska. Jest ono tym rodzajem stuchania, w które } \\
\text { potrafi się wczuć wyłacznie syn w obliczu ojca, } \\
\text { bo oświecony jest pewnościa, że ojciec ma mu do } \\
\text { powiedzenie i do ofiarowania tylko rzeczy dobre; } \\
\text { stuchania przenikniętego ta ufnościa, która sprawia, } \\
\text { że syn przyjmuje wolę ojca pewny, że będzie to dla } \\
\text { jego dobra. }\end{array}$ & $\begin{array}{l}\text { Posłuszeństwo jest przede wszystkim tym rodzajem } \\
\text { stuchania, które daje pewność, że rodzic/wychowawca } \\
\text { ma dziecku do powiedzenie i do ofiarowania tylko } \\
\text { rzeczy dobre; jest rodzajem stuchania przenikniętego } \\
\text { ta ufnościa, która sprawia, że dziecko przyjmuje wole } \\
\text { rodzica/wychowawcy pewny, że będzie to dla jego } \\
\text { dobra. }\end{array}$ \\
\hline $\begin{array}{l}\text { Postuszeństwo Bogu jest droga wzrostu, a zatem } \\
\text { wolności osoby, gdyż pozwala przyjác plan albo wole } \\
\text { inna od własnej woli, która nie tylko nie upokarza } \\
\text { albo pomniejsza godność ludzka, ale ją buduje. } \\
\text { Jednocześnie wolność jest sama w sobie także droga } \\
\text { posłuszeństwa, bo przez dziecięce postuszeństwo } \\
\text { zamysłowi Ojca, człowiek wierzący urzeczywistnia } \\
\text { swoje bycie wolnym. }\end{array}$ & $\begin{array}{l}\text { Postuszeństwo jest droga wzrostu, a zatem wolności } \\
\text { osoby, gdyż pozwala przyjać plan albo wolę, która } \\
\text { nie tylko nie upokarza, nie pomniejsza godności, ale } \\
\text { ja buduje. Jednocześnie wolność jest sama w sobie } \\
\text { także droga posłuszeństwa, bo przez posłuszeństwo, } \\
\text { wychowanek urzeczywistnia swoje bycie wolnym. }\end{array}$ \\
\hline \multicolumn{2}{|c|}{ WŁADZA W SŁUŻBIE POSŁUSZEŃSTWA } \\
\hline $\begin{array}{l}\text { Władza jest powołana, by promować godność } \\
\text { osoby, w trudnościach wzbudzać odwagę i nadzieję, } \\
\text { towarzyszyć na drodze formacji ciąłej. }\end{array}$ & $\begin{array}{l}\text { Władza jest powołana, by promować godność } \\
\text { osoby, w trudnościach wzbudzać odwagę i nadzieje, } \\
\text { towarzyszyć na drodze wzrostu. }\end{array}$ \\
\hline $\begin{array}{l}\text { Przewodnik wspólnoty jest jak dobry pasterz, który } \\
\text { poświęca swoje życie owcom, także dlatego, że w } \\
\text { chwilach krytycznych nie wycofuje się, ale jest obecny } \\
\text { oraz uczestniczy w zmartwieniach i trudnościach osób } \\
\text { powierzonych jego trosce, angażując się osobiście. } \\
\text { I podobnie jak dobry samarytanin będzie on gotów } \\
\text { leczyć ewentualne rany. }\end{array}$ & $\begin{array}{l}\text { Rodzic/wychowawca poświęca swoje życie dzieciom/ } \\
\text { wychowankom, także dlatego, że w chwilach } \\
\text { krytycznych nie wycofuje się, ale jest obecny, } \\
\text { uczestniczy w zmartwieniach i trudnościach, } \\
\text { angażujac się osobiście, zawsze gotowy leczyć } \\
\text { i opatrywać ewentualne rany, zranienia. }\end{array}$ \\
\hline $\begin{array}{l}\text { Zadaniem, które dziś należy uznać za coraz } \\
\text { ważniejsze ze strony władzy, jest towarzyszenie na } \\
\text { drodze życia powierzonym jej osobom. To zadanie } \\
\text { wypetnia ona nie tylko poprzez niesienie pomocy } \\
\text { w rozwiazywaniu ewentualnych problemów albo } \\
\text { w pokonywaniu możliwych kryzysów, ale też przez } \\
\text { troskę o normalny rozwój każdej osoby na wszystkich } \\
\text { etapach i we wszystkich okresach życia. }\end{array}$ & $\begin{array}{l}\text { Zadaniem, które dziś należy uznać za coraz } \\
\text { ważniejsze ze strony władzy, jest towarzyszenie na } \\
\text { drodze życia powierzonym jej osobom. To zadanie } \\
\text { wypełnia ona nie tylko poprzez niesienie pomocy } \\
\text { w rozwiązywaniu ewentualnych problemów albo } \\
\text { w pokonywaniu możliwych kryzysów, ale też przez } \\
\text { troskę o normalny rozwój każdej osoby na wszystkich } \\
\text { etapach i we wszystkich okresach życia. }\end{array}$ \\
\hline
\end{tabular}

${ }^{18}$ Opracowanie własne. 
Obowiązkiem władzy będzie więc utrzymanie $w$ każdej osobie wysokiego poziomu gotowości formacyjnej, umiejętności czerpania z doświadczenia $\dot{z} y c i a$, dobrowolnego poddania się kształtowaniu przez innych i poczuwania się do odpowiedzialności za droge wzrostu innych.
Obowiązkiem władzy wychowawczej jest utrzymanie w każdym wychowanku umiejętności czerpania $z$ doświadczenia życia, dobrowolnego poddania się kształtowaniu przez innych i poczuwania się do odpowiedzialności za drogę wzrostu innych.

\section{ROZEZNANIE, WŁADZA I POSŁUSZEŃSTWO}

Władza winna być wytrwała $w$ delikatnym procesie rozeznania, troszczac się o jego etapy $i$ dodajac otuchy $w$ chwilach najbardziej krytycznych, a zarazem stanowcza w wykonaniu podjetych decyzji.

Będzie uważała, aby nie abdykować z własnej odpowiedzialności, ze względu na umiłowanie życia $w$ świętym spokoju albo z obawy przed czyjąś drażliwością. Będzie czuła się odpowiedzialna $z a$ to, by nie uciekać $w$ sytuacjach, w których trzeba podejmować decyzje jasne, choć niekiedy nieprzyjemne.

Prawdziwa miłość do wspólnoty uzdalnia władze do łączenia stanowczości i cierpliwości, wystuchania każdej osoby i odważnego podejmowania decyzji, przezwyciężając pokusę bycia głuchym i niemym.

Na pewno nie jest wolnym ten, kto jest przekonany, $\dot{z}$ e jego idee i jego rozwiąania sa najlepsze; kto uważa, że sam potrafi podejmować decyzje, bez jakiegokolwiek pośrednictwa $w$ poznawaniu woli Bożej; kto uważa, że zawsze ma rację i nie ma wątpliwości, że to inni powinni się zmienić; kto myśli jedynie o swoich sprawach $i$ nie zwraca żadnej uwagi na potrzeby innych; kto sądzi, że posłuszeństwo jest czymś przestarzalym, a zatem niemożliwym do proponowania $w$ świecie bardziej rozwiniętym.

Kto w petnieniu urzędu szuka sposobu, by się wybić albo zdobyć uznanie, pozwolić sobie służyć, albo innych sobie podporządkowywać, stawia się w sposób wyraźny poza ewangelicznym wzorem władzy.

Mimo, że władza nie może (i nie musi) robić wszystkiego, na niej spoczywa ostateczna odpowiedzialność za wszystko.

Władza będzie troszczyła się o to, by dzielić się nie tylko informacjami, ale także odpowiedzialnościa, angażując się z kolei $w$ uszanowanie każdego w jego własnej, słusznej autonomii. Wiąże się to, ze strony władzy, z cierpliwym wysitkiem koordynowania, a ze strony osoby konsekrowanej szczera gotowościa do wspótpracy.
Władza rodzicielska/wychowawcza winna być wytrwała w procesie wspierania rozwoju, troszczac się o jego etapy $i$ dodajac otuchy $w$ chwilach najbardziej krytycznych, a zarazem stanowcza $w$ wykonaniu podjętych decyzji. Będzie uważała, aby nie abdykować $z$ własnej odpowiedzialności, ze względu na umiłowanie życia w świętym spokoju albo z obawy przed czyjąś drażliwością. Będzie czuła się odpowiedzialna za to, by nie uciekać w sytuacjach, w których trzeba podejmować decyzje jasne, choć niekiedy nieprzyjemne.

Prawdziwa miłość do wychowanków uzdalnia rodziców/wychowawców do łączenia stanowczości i cierpliwości, wysłuchania dziecka w każdym czasie i odważnego podejmowania decyzji, przezwyciężając pokusę bycia głuchym i niemym.

Nie jest wolnym ten, kto jest przekonany, że jego idee i jego rozwiązania sa najlepsze; kto uważa, że zawsze ma rację i nie ma wątpliwości, że to inni powinni się zmienić; kto myśli jedynie o swoich sprawach i nie zwraca żadnej uwagi na potrzeby innych; kto sadzi, że postuszeństwo jest czymś przestarzałym, a zatem niemożliwym do proponowania $w$ świecie bardziej rozwiniętym.

Kto w sprawowaniu władzy szuka sposobu, by sie wybić albo zdobyć uznanie, pozwolić sobie służyć, albo innych sobie podporządkowywać, stawia się w sposób wyraźny poza wzorem władzy.

Mimo, że władza nie może ( $i$ nie musi) robić wszystkiego, na niej spoczywa ostateczna odpowiedzialność za wszystko.

Władza wychowawcza będzie troszczyła się o to, by dzielić się nie tylko informacjami, ale także odpowiedzialnościa, angażując się z kolei w uszanowanie każdego dziecka w jego własnej, słusznej autonomii. Wiąże się to, ze strony władzy, z cierpliwym wysitkiem koordynowania, a ze strony wychowanka szczera gotowościa do współpracy. 


\begin{tabular}{|l|l|}
\hline Władza jest powołana do tego, by rozwijać pedagogię & Władza jest powołana do tego, by rozwijać pedagogię \\
przebaczenia i miłosierdzia, to znaczy by być & przebaczenia, stwarzając nowa możliwość dla tych, \\
narzędziem miłości Bożej, która przygarnia, poprawia & którzy popełniają błędy. Musi pamiętać, że bez \\
i zawsze stwarza nowa możliwość dla tych braci albo & nadziei przebaczenia człowiek z trudem podejmie \\
sióstr, którzy popełniaja błędy i popadaja w grzech. & swoja wędrówkę i nieuchronnie zmierzać będzie ku \\
Musi pamiętać, że bez nadziei przebaczenia człowiek & temu, by dorzucić zło do zła, upadki do upadków. \\
z trudem podejmie swoja wędrówkę i nieuchronnie & \\
zmierzać będzie ku temu, by dorzucić zło do zła, & \\
upadki do upadków. & \\
\hline $\begin{array}{l}\text { Jednak i władza może popaść w zniechęcenie } \\
\text { i w rozczarowanie (...). Wówczas jawi się } \\
\text { niebezpieczeństwo popadnięcia w rutynę, godzenia } \\
\text { się na mierność, powstrzymywania się od działania, } \\
\text { braku odwagi, by wskazać cele autentycznego życia } \\
\text { konsekrowanego, narażając się w ten sposób na } \\
\text { utratę pierwotnej żarliwości i woli dawania o niej } \\
\text { świadectwa. }\end{array} \quad$ braku odwagi, by wskazać cele wychowania. \\
\end{tabular}

\section{Podsumowanie}

Współczesny człowiek potrzebuje i poszukuje autorytetów. Wolność jest cenna dla tych, którzy potrafią z niej korzystać. Brak zdolności radzenia sobie z posiadaną wolnością jest źródłem nieszczęścia jednostki, stąd potrzeba zmiany w podejściu do władzy rodziców/wychowawców oraz w rozumieniu posłuszeństwa w procesie wychowania. Jeśli: 1) władza wychowawcy pozostawać będzie w służbie posłuszeństwa wychowanków, 2) posłuszeństwo będzie rozumiane jako wsłuchiwanie się w głos autorytetu, 3) autorytet wychowawcy będzie wynikał $\mathrm{z}$ wolnego wyboru dokonanego przez wychowanka, to mądrość wychowania polegać będzie na przechodzeniu od szacunku wobec dzierżących władzę do ich autorytetu uznawanego przez wychowanka, i dalej od samodzielnie uznanego i przyjętego autorytetu do posłuszeństwa wychowanka wobec rodziców/wychowawców.

\section{Bibliografia}

Arendt H., Między czasem minionym a przyszłym. Osiem ćwiczeń z myśli politycznej, Fundacja ALETHEIA, Warszawa 1994.

Barszcz W., Watykan: instrukcja o zakonnej władzy i postuszeństwie, http://kosciol. wiara.pl/doc/494251.Watykan-Instrukcja-o-zakonnej-wladzy-i-posluszenstwie (dostęp: 01.03.2017).

Fromm E., Mieć czy być, Dom Wydawniczy „Rebis”, Poznań 2005.

Jasiński Z., Zaufanie w pedagogice Janusza Korczaka, [w:] J. Bińczycka (red.), Korczakowskie dialogi, Wydawnictwo Akademickie „Żak”, Warszawa 1999. 
Jazukiewicz I., O szacunku, http://www.edukacyjne.dyskursy.univ.szczecin.pl/szacunku.htm (dostęp: 01.03.2017).

Kongregacja ds. Instytutów Życia Konsekrowanego i Stowarzyszeń Życia Apostolskiego, Postuga władzy i posłuszeństwo. Faciem tuam, Domine, requiram. Instrukcja, http://www.vatican.va/roman_curia/congregations/ccscrlife/documents/rc con ccscrlife doc 20080511 autorita-obbedienza pl.html (dostęp: 01.03.2017).

Kunicka M., Linguistic landscape wokót procesu wychowania. Archaizmy i eufemizmy jako enklawy językowe, „Teraźniejszość - Człowiek - Edukacja”, nr 1(65)/2014, s. 129-141.

Parzyszek Cz., Posłuszeństwo i posługa władzy - odpowiedzia na zagrożenia współczesnej cywilizacji, „Warszawskie Studia Pastoralne”, nr 9/2009, s. 90-116, http:// mazowsze.hist.pl/27/Warszawskie Studia Pastoralne/625/2009/22612/ (dostęp: 01.03.2017).

Pasikowski S., Postuszeństwo wobec autorytetu nauczyciela w sytuacji wcześniejszego wzbudzania lub redukowania indywidualnego poczucia władzy, „Kultura i Edukacja", nr 4(90)/2012, s. 34-44. https://depot.ceon.pl/bitstream/handle/123456789/8871/Pasikowski S. Pos\%C5\%82uszenstwo wobec\%20autorytetu nauczyciela.pdf?sequence=1\&isAllowed =y (dostęp: 01.03.2017).

Sławiński S., Wychowywać do posłuszeństwa, Instytut Wydawniczy PAX, Warszawa 1994.

\title{
Authority and Obedience in the Upbrining Process (Based on the Instruction The Service of Authority and Obedience)
}

Abstract: In the „culture of abundance”, created in the world of liberal beliefs, there is no place for the upbringing a child in the spirit of obedience. Apologists of the permissive upbringing equate human freedom with excessive tolerance, superseding authoritarianism, but reject the upbringing to obedience. However there is a need of raising a young human to responsibility, temperance, honesty, and respect for another. This becomes possible in a situation where the nurturer's authority is understood as service and the child's obedience is understood as a willful submission to the voice of the nurturer.

Keywords: upbringing, authority, power

\begin{abstract}
About the author: Dr Małgorzata Kunicka - PhD in Pedagogy, current place of employment: University of Szczecin, Faculty of Humanities, Department of Pedagogy, Department of Early Childhood Education. Scientific interests: early school education, axiology, teleology. Author of a monograph on education entitled Temporalne orientacje teleologiczne nauczycieli a lot of research papers in ranked scientific journals on education, i.a. in „Teraźniejszość - Człowiek - Edukacja”, „Opuscula Sociologica”, „Forum Oświatowe”, „Kultura - Media - Teologia”, „Kultura i Wychowanie”, as well as a number of publications in books (in total nearly 50 publications).
\end{abstract}




\section{Dietrich Benner}

Humboldt-Universität zu Berlin

dietrich.benner@gmx.de

\section{Recenzja książki: Thomas Rucker, Komplexität der Bildung. Beobachtungen zur Grundstruktur bildungstheoretischen Denkens in der (Spät-)Moderne, Verlag Julius Klinkhardt, Bad Heilbrunn 2014}

Lekturę monografii Thomasa Ruckera trzeba rozpocząć od bardzo skrupulatnego odczytania jej tytułu. Na jego początku autor umieścił wyrażenie Komplexität der Bildung (po polsku 'złożoność kształcenia'). Podstawą do omówienia tego zagadnienia są obserwacje poczynione przez niego w trakcie analizowania struktur myślenia utrwalonych w dyskursach na temat kształcenia. Rucker przebadał dyskursy prowadzone w nowoczesności, głównie w jej późnej fazie, której nie należy utożsamiać zbyt pochopnie z ponowoczesnością ani etykietować jako przejścia do niej. Tak odczytany tytuł stawia w centrum rozważań problem złożoności kształcenia. Specyfikuje ona myślenie pedagogiczne w nowoczesności i ze zdwojoną siłą dochodzi do głosu współcześnie.

Z jakich powodów Rucker nadał swojej monografii taki tytuł, sam autor wyjaśnia w dziewięciu sekcjach, z których składa się rozdział wprowadzający (s. 9-28). $\mathrm{W}$ pierwszej formułuje tezę, że z pomocą narzędzi teoretycznych wypracowanych w zyskującej ostatnio na rozgłosie i zainteresowaniu badaczy teorii złożoności da się usystematyzować procesy kształcenia. Jego zdaniem na szczególną uwagę w teorii złożoności zasługują takie kategorie, jak „otwartość” (Offenheit), „niepewność” (Ungewissheit), „nieplanowalność” (Nichtplanbarkeit) i „niesterowalność” (Nichtsteuerbarkeit). Adaptacja tych kategorii do teorii kształcenia jest potrzebna przede wszystkim dlatego, że we współczesnych analizach fenomenu kształcenia coraz wyraźniej uwidacznia się zjawisko złożoności, które domaga się wyjaśnienia i zrozumienia. Na tym tle eksploracja złożoności kształcenia wydaje się przedsięwzięciem oryginal- 
nym i wartym uwagi, nie mówiąc już o tym, że w pedagogice niemieckiej - jak do tej pory - nie było dyskusji na ten temat (s. 13).

W drugiej sekcji Rucker kontynuuje rozpoczęty powyżej wątek. Stwierdza mianowicie, że na początku swoich poszukiwań odczuwał niedosyt potencjału poznawczego (s. 14), który pozostawiały w nim teorie kształcenia. Tłumaczył to sobie ich standardowym, jeżeli nie stereotypowym, podejściem do problemu kształcenia. To odczucie zmieniło się jednak, gdy sięgnął po kategorię złożoności w ogólnych teoriach tego fenomenu. Niemniej jednak autor uważa post factum, że złożoność można było dostrzec również we wskazanych teoriach kształcenia, a to dlatego, że jego zdaniem złożoność, zanim stała się przedmiotem badań współczesnej nauki (np. ogólnej teorii złożoności - D. B.), istniała implicite $w$ teoriach kształcenia (s. 14).

W trzeciej sekcji Rucker scharakteryzował stan recepcji teorii złożoności w pedagogice niemieckiej i nakreślił perspektywy rozwoju tego - jak się wydaje - nowego i godnego uwagi podejścia analitycznego. Według omawianego autora w niemieckich naukach o wychowaniu prawie w ogóle nie zauważa się (jeszcze) międzynarodowych badań nad złożonością. Jedynym badaczem, który przybliża i rozwija to podejście w swoich publikacjach, jest Elmar Anhalt. Jemu należy też przypisać zasługę wyjaśnienia, jak w ramach teorii pedagogicznej można zajmować się analiza złożoności wychowania, [...] jakie problemy da się dzięki niej zidentyfikować i jak można następnie starać się je rozwiązać (s. 17). W kontekście badań Anhalta autor wyprowadza dwa ważne wnioski: po pierwsze, wbrew powierzchownym przypuszczeniom, problematyka złożonych zależności, które determinuja wychowanie i kształcenie, ma w niemieckiej nauce o wychowaniu długa tradycje (s. 17) i, po drugie, $w$ związku $z$ tym należy wyselekcjonować teksty należace do tej tradycji, które werbalizują złożoność i warte są systematycznej eksploracji (s. 17).

Czwarta sekcja zawiera szkic projektu badawczego mającego na celu uczynienie problematyki złożoności przedmiotem badań podstawowych w pedagogice. Badania te, zdaniem Ruckera, należy prowadzić zgodnie ze wskazanym powyżej założeniem, że kształcenie jest szyfrem złożoności (s. 15), który już od dawna jest obecny w naukach o wychowaniu. Nawiązując raz jeszcze do Anhalta, Rucker w centrum swojego zamierzenia badawczego sytuuje nie rozwiązania, które proponuja teorie naukowe, [...] lecz problemy (s. 18). Te ostatnie mają jego zdaniem pełnić funkcję „motorów napędzających postęp wiedzy” (s. 18). W tym kontekście szczególnego znaczenia nabiera fakt, że postulując podjęcie pedagogicznych badań podstawowych nakierowanych na analizę złożoności kształcenia, Rucker nie sugeruje prostej transpozycji ustaleń poczynionych w ogólnej teorii złożoności do teorii wychowania i teorii kształcenia, lecz domaga się opracowania własnego programu badawczego o charakterze inter- i intradyscyplinarnym. W programie tym za punkt wyjścia należy przyjąć takie pojmowanie złożoności, jakie jest obecne w niewypowiedziany sposób w pedagogicznej praxis oraz w zwerbalizowanej formie w teoriach pedagogicznych.

Postulowany przez Ruckera program badań podstawowych umożliwi prześledzenie złożoności stanu rzeczy określanego mianem „kształcenie”, tak jak on był i jest kon- 
cypowany w teoriach kształcenia (s. 19). Równocześnie należy zauważyć, że z tego programu nie wynika żadna konieczność usytuowania pojęcia „kształcenie” w centrum wysiłków badawczych. Wręcz przeciwnie, dopuszcza się możliwość innego uporządkowania dziedziny wychowania i kształcenia.

W piątej sekcji autor wyjaśnia, jak należy ukonkretnić awizowany powyżej program badawczy, dążąc do możliwie najpełniejszego uchwycenia fenomenu złożoności kształcenia. W tym celu Rucker proponuje wykorzystanie następujących kategorii: „Współzależność” (Wechselspiel), „autoreferencyjność” (Selbstreferentialität), „dynamiczność” (Dynamik), „emergencja” (Emergenz), „otwartość” (Offenheit), „niepewność” (Ungewissheit), „nieplanowalność” (Nichtplanbarkeit) i „niesterowalnośc” (Nichtsteuerbarkeit) (s. 20).

Szósta sekcja stanowi przygotowanie do zastosowania charakteryzowanego podejścia badawczego do problemu kształcenia. W ramach tego przygotowania Rucker rozróżnia trzy grupy teorii kształcenia. W pierwszej z nich uwaga teoretyków koncentruje się na wypracowanym przez Theodora Bellauffa rozumieniu kształcenia jako centralnego pojęcia pedagogicznego. Drugą grupę stanowią dyskursy na temat kształcenia, w której zgodnie ze stanowiskiem Heinza-Elmara Tenortha kształceniu wyznacza się bardzo szerokie granice, nie ograniczając go do nauk o wychowaniu. W trzeciej grupie definiuje się je jako centralnq kategorię badawcza (Krassimir Stojanov). W tym miejscu warto zwrócić uwagę, że Rucker stara się zharmonizować wymienione trzy grupy teorii przez to, że (podążając za Bellauffem) odczytuje kształcenie jako podstawowe pojęcie pedagogiczne, które umożliwia systematyczną konstrukcje jego własnej struktury treściowej (s. 20). To założenie nie sprawdza się jednak wobec niektórych autorów, o których mowa jest w następnym rozdziale. Część z nich bowiem omawianej problematyce przypisuje znaczenie, którego nie da się podporządkować aksjomatowi absolutnego prymatu kształcenia.

Kolejne dwie sekcje pomagają zrozumieć, dlaczego opracowanie Ruckera dotyczy późnej nowoczesności (sekcja siódma) i dlaczego bada on złożoność z pomocą wymienionych powyżej kategorii (sekcja ósma). Autor przypisuje tym kategoriom funkcję wzorów umożliwiających orientację (s. 24). Chodzi mu oczywiście o orientację w gąszczu stanowisk teoretycznych i przez to lepsze zrozumienie, co we współczesnych empirycznych badaniach pedagogicznych rozumie się pod pojęciem kształcenia.

W powyższym kontekście należy zauważyć, że zaproponowane kategorie złożoności kształcenia („współzależność”, „autoreferencyjność”, „dynamiczność”, „emergencja”, „otwartość”, „niepewność”, „nieplanowalność” i „niesterowalność”) wymagają interpretacji nie tylko z perspektywy teorii kształcenia, lecz również wychowania. Dopiero wtedy, gdy uwzględni się te dwa typy teorii, czy raczej dwa komplementarne aspekty rzeczywistości pedagogicznej, można powiedzieć, że dziedzina podstawowych badań pedagogicznych została ujęta w całości. Ruckerowi chodzi głównie o wyjaśnienie kwestii „nieplanowalności” i „niesterowalności” procesów wychowania i kształcenia. Uważa on, że dzięki złożoności i jej cechom da się uniknąć jałowych 
przeciwstawień, takich jak: „planowalne” versus „nieplanowalne” i „sterowalne” versus „niesterowalne”. Dalej Rucker projektuje, że jeśli odniesienie do Herbarta i innych klasyków pedagogiki respective teorii kształcenia opartych na zasadach i formach wychowania i kształcenia okaże się sensowne, to wówczas możliwe będzie również postawienie pytania o przyczynowość pedagogiczną i techniki stosowane $\mathrm{w}$ procesach pedagogicznych. To z kolei pozwoli na ustalenie wspomnianych już wzorów umożliwiajacych orientacje (s. 24) w obszarze teorii kształcenia. Głównym zadaniem tych wzorów jest przeciwdziałanie tendencji do zastępowania pojęcia wychowania pojęciem kształcenia i do przypisywania pedagogicznej wyłączności zmiennym procesom kształcenia.

Omówione powyżej sekcje tworzą osiem etapów argumentacji, w której autor przekonuje czytelnika o doniosłości podjętej przez siebie problematyki. Zwieńczeniem tego ciągu jest prezentacja zawartości rozprawy, którą zawiera dziewiąta i ostatnia sekcja.

Rozdział wprowadzający miał nie tylko zaznajomić czytelnika z problemem złożoności w pedagogice, lecz również rozpoczynał badanie przeprowadzone przez Ruckera. Do zasygnalizowanych w nim kwestii autor powraca w kolejnych rozdziałach i omawia je szczegółowo. W rozdziale drugim (s. 29-60) na czoło wysuwa się określenie właściwego postępowania metodologicznego. Autor powołuje się na kilkuletnią współpracę z Anhaltem i wypracowany w jej trakcie model teoretyczny, który poddał sprawdzeniu w kolejnych rozdziałach niniejszego opracowania. Dzięki odniesieniu do badań Anhalta zamierzenie badawcze Ruckera zyskało niewątpliwie na jednoznaczności. Omawiany autor zmierza do zespolenia podejścia interdyscyplinarnego właściwego ogólnej teorii złożoności z dziedziną podstawowych badań pedagogicznych. Swój cel chce osiągnąć przez to, że: po pierwsze, będzie kierował się perspektywą pedagogiczną, jednak nie w sposób „ekskluzywny”, lecz „inkluzywny”, to znaczy szukając połączeń z innymi perspektywami patrzenia na fenomen złożoności; po drugie, ustanawia jako centralną oś problemową pytanie o wspieranie rozwoju przez uczenie się (s. 51) i wreszcie, po trzecie, w ramach teorii wychowania i kształcenia rozróżnia odmienne i nieredukowalne sposoby stawiania problemów pedagogicznych. Jego zdaniem ostatnie rozróżnienie otwiera przed refleksją pedagogiczną możliwość takiego formułowania problemów, które nie spowoduje jej immunizacji na procedury falsyfikacyjne, które zdominowały współczesną naukę, w tym również naukę o wychowaniu, lecz doprowadzi do transformacji starych i odkrycia nowych kwestii.

Następnie Rucker w szczegółach wyjaśnia swoje postępowanie badawcze, odwołując się do teorii Niklasa Luhmanna, a zwłaszcza do wprowadzonego przez niego rozróżnienia między obserwatorem pierwszego i drugiego poziomu (por. s. 54 i n.). Również tego rozróżnienia autor nie traktuje aksjomatycznie, tzn. jako warunek sine qua non, lecz jako umożliwienie - przynajmniej na pewien czas - obserwowania siebie samego jako obserwatora pierwszego poziomu z pozycji obserwatora drugiego poziomu i vice versa - jako obserwatora drugiego poziomu z pozycji obserwatora 
pierwszego poziomu. Rucker twierdzi, że dzięki tej myślowej roszadzie ról będzie można odkryć problemy, które kryją się na granicy interdyscyplinarnej teorii złożoności i dziedziny podstawowych badań pedagogicznych.

Patrząc od strony wspomnianego powyżej pogranicza, można zauważyć, że dzięki uwzględnieniu zróżnicowania perspektyw obserwatora pierwszego i drugiego poziomu realizacja celu wspierania rozwoju jednostki przez uczenie się zdobywa autonomiczną strukturę. Ten wniosek dotyczy w szczególności teorii wychowania i teorii kształcenia. Formułowane w ich ramach propozycje rozwoju przez uczenie się nie mogą ograniczać się do wskazówek psychologicznych i/lub socjologicznych, lecz muszą uwzględniać stricte pedagogiczne formy działania edukacyjnego, takie jak dyscyplinowanie, nauczanie wychowujące i kierownictwo. To wskazanie oznacza, że obserwacje pedagogicznych stanów rzeczy, podejmowane z perspektywy nauki o wychowaniu, są w wysokim stopniu narażone na mylne ujmowanie swojego przedmiotu. Chcąc temu przeciwdziałać, należy poddawać je sprawdzaniu pod względem pełnego ujmowania złożoności rzeczywistości pedagogicznej. Sprawdzanie to winno się przeprowadzać zarówno w odniesieniu do wiedzy ogólnej (pedagogiki ogólnej), jak i szczegółowej (pedagogiki z przydawką, np. pedagogiki społecznej). Jednym z najważniejszych zakresów owego sprawdzania jest ustalenie, czy uczenie się i wspieranie uczenia się są przedmiotem teorii złożoności i podstawowych badań pedagogicznych jedynie w sensie psychologicznym, czy również jako działania pedagogiczne o charakterze dyscyplinującym, nauczającym i kierującym.

Rozdział trzeci został opatrzony tytułem Bildung (Kształcenie). Autor odniósł się w nim do różnych stanowisk teoretycznych na temat kształcenia, m.in. Tenortha, Meyer-Drawe, Rickena, Schäfera, Kollera, Reichenbacha, Heitgera i Bennera. Jego własne poglądy wydają się opierać na rozumieniu kształcenia jako procesu o charakterze zwrotnego sprzężenia między Ja podmiotowym i światem. W tym kontekście Rucker szerzej odwołuje się do Wilhelma von Humboldta, którego teorię kształcenia przedkłada ponad opisy kształcenia przedstawione przez współczesną autorkę Käte Meyer-Drawe. Ta ostatnia rozważa kształcenie w ścisłym powiązaniu z problematyką zdobywania autonomii przez zapoznany i niedoceniany jej zdaniem podmiot nowożytny. W przeciwieństwie do jej teorii von Humboldt i inni teoretycy kształcenia, tacy jak Herbart czy Fichte, nie rościli pretensji do osiągnięcia przez podmiot w toku kształcenia całkowitej autonomii. W nawiasie można dodać, że przez stylizację, jaką posługuje się Meyer-Drawe, jej argumentacja nie trafia w pedagogiczny wymiar kwestii kształcenia. Autorka rozważa bowiem fenomen kształcenia w sposób abstrakcyjny i filozoficzny, pomijając całkowitym milczeniem proces kształcenia i jego uwarunkowania pedagogiczne. Tymczasem już około roku 1800 Herbart zaproponował wyodrębnienie trzech typów pedagogicznej praxis, a mianowicie: działanie dyscyplinujące, nauczające i kierujące, przez co sprzeciwił się konstruowaniu modeli pedagogicznych opartych wyłącznie na abstrakcyjno-filozoficznych analizach podmiotu. Na tym tle można stwierdzić w odniesieniu do całego trzeciego rozdziału omawianej rozprawy, 
że omówieni w nim autorzy, z wyłączeniem Anhalta, Bennera i Tenortha, redukują złożoność pojęcia kształcenia przez to, że nie rozpatrują czynności kształcenia w powiązaniu z wychowaniem, lecz ujmują je tak, jakby dokonywały się poza działaniem wychowawczym. Oprócz tego ci sami autorzy w opisie kształcenia posługują się terminologią, która przemilcza rozróżnienia ważne z punktu widzenia sfery publicznej, takie jak: „kształcenie ogólne”, „propedeutyka nauki”, „przygotowanie do zawodu”, „formy wiedzy”, „poziomy kształcenia”.

Rucker zatytułował czwarty rozdział Komplexität (Złożoność). Swoje rozważania rozpoczął od wyjaśnienia, czym w kontekście badań transdyscyplinarnych jest złożoność. Niewątpliwie podjęta przez niego problematyka sytuuje się „,w poprzek" podziałów obowiązujących do tej pory w nauce między zakresami, obszarami i dyscyplinami naukowymi (s. 105). Patrząc z punktu widzenia głównego problemu rozprawy, a mianowicie możliwości scalenia pedagogicznej teorii złożoności i badań podstawowych w pedagogice, na szczególną uwagę zasługują uwagi autora dotyczące błędów, jakich należy unikać przy implementowaniu dotychczasowych wyników analiz fenomenu złożoności w naukach przyrodniczych na nauki społeczne i humanistyczne. W tym kontekście dużo miejsca poświęcił parametrom złożoności (s. 127-148). Omówił je w odniesieniu do procesu kształcenia najpierw ogólnie, a następnie szczegółowo w stosunku do przyjętych na początku rozprawy kategorii: „współzależności”, „autoreferencyjności”, „dynamiczności”, „emergencji”, „otwartości”, „niepewności”, „nieplanowalności” i „niesterowalności”.

To, co zostało opisane w rozdziałach trzecim i czwartym, autor zsyntetyzował w kolejnym, piątym, któremu nadał tytuł Komplexität der Bildung, czyli Złożoność kształcenia. Należy z naciskiem podkreślić, że treść rozdziałów trzeciego, czwartego i piątego jest spójna i autor konsekwentnie rozwija w nich postawiony problem badawczy. Nie jest to jednak jedyny możliwy sposób podejścia do kwestii złożoności. Rozważania Ruckera potoczyłyby się inaczej, gdyby wybrał inne teorie lub w inny sposób zaaranżował toczący się między nimi dyskurs. Autor niniejszej recenzji jest zdania, że refleksję nad złożonością należy prowadzić nie tylko z perspektywy ogólnej teorii złożoności, tzn. jako pewnego rodzaju aplikację jej kategorii do teorii kształcenia i wychowania, lecz również w odwrotnym kierunku. Wynika to stąd, że w ogólnych analizach fenomenu złożoności przyjmuje się implicite pewne założenia, których zrozumienie jest możliwe dopiero po włączeniu do dyskusji teorii wychowania i kształcenia. $Z$ tego punktu widzenia analizy ogólnej teorii złożoności nie są w stanie własnymi siłami uzasadnić niektórych odkrytych w nich prawidłowości i w tym sensie są skazane na dopełnienie przez pedagogów.

Ilustracją powyższej współzależności może być rozważenie więzi między ewolucją i jej teorią. Kształcenie jako swobodne oddziaływanie dokonujące się między człowiekiem a światem i teoria kształcenia jako teoria owego oddziaływania są starsze niż teoria ewolucji, ale to nie wszystko. Ta ostatnia mogła rozwinąć się dopiero po tym, gdy w nowożytnych i współczesnych procesach kształcenia przełamana została 
systematyka teleologicznego porządku myślenia i zaczęto analizować go w nowym paradygmacie - refleksyjnym.

Wydaje się, że coś podobnego odnosi się również do stosunków między dyskursami teoretycznymi na temat wychowania i kształcenia a ogólną teorią złożoności. To, co obserwuje się z perspektywy tej ostatniej i wykazuje jako złożoność procesów wychowania i kształcenia, nie powstaje bynajmniej wskutek oddziaływań odpowiadających teorii złożoności, lecz właśnie dzięki procesom pedagogicznym, które podlegają refleksji teoretycznej w odniesieniu do wychowania i kształcenia. W takiej sytuacji do zakresu złożoności pedagogicznej należałoby zaliczyć również to, że trzeba dokonać rozróżnienia między procesami kształcenia dokonującymi się poza wychowaniem i tymi, do których warunków i kontekstu wychowanie należy nierozerwalnie. Trzeba przyznać, że w części rozważań przeprowadzonych przez Ruckera nie dostrzega się tego ważnego rozróżnienia. Nie może więc dziwić, że wskazania, których udziela zarówno co do teorii kształcenia, jak i podstawowych badań pedagogicznych, dotyczą wyimaginowanej przestrzeni wolnej od wychowania.

Łącząc w piątym rozdziale teorię kształcenia i teorię złożoności, Rucker układa przyjęte przez siebie kategorie procesu kształcenia („współzależność”, „autoreferencyjność”, „dynamiczność”, „emergencja”, „otwartość”, „niepewność”, „nieplanowalność” i „niesterowalność”) w pewien porządek, który w pierwszym rzędzie odnosi się do problemów teorii kształcenia, ale ma również zastosowanie w kwestiach dotyczących teorii wychowania.

Rozdział piąty i kolejny - szósty - tworzą szczyt rozważań przedstawionych w monografii przez Ruckera. W opisie kategorii i ich cech autor odwołuje się na przemian do argumentów pochodzących z ogólnej teorii złożoności i teorii pedagogicznych - wychowania i kształcenia. Ten dość trudny do prześledzenia dyskurs porządkuje schemat zamieszczony na stronie 172, w którym przedstawiono wzajemne oddziaływania między wielokrotnie już wymienianymi kategoriami, co umożliwia również analizę modelu ze względu na kategorię negatywności doświadczenia.

Za główny produkt rozważań przeprowadzonych przez Ruckera w szóstym rozdziale można uznać „punkty oparcia” (Haltepunkte). Pod tym wyrażeniem kryją się stwierdzenia dotyczące właściwych sposobów działania pedagogicznego. Autor wskazuje na następujące „zasady”: (1) brak zdeterminowania procesu kształcenia, (2) niemożność narzucenia człowiekowi kształcenia przez oddziaływania wychowawcze, (3) konieczność właściwego, tzn. odpowiadającego specyfice tych zjawisk, obchodzenia się z wychowanie i kształceniem w zakresie tego, czego nie da się uregulować, (4) pedagogiczne uznanie godności człowieka znajdującego się w procesie samokształcenia i (5) nieredukowalny deficyt technologii pedagogicznych.

W siódmym i ostatnim rozdziale Rucker przedstawia nie tylko resume przeprowadzonych rozważań, lecz również stawia pytania odnośnie do struktury przyszłych badań edukacyjnych, w których problematyka złożoności zostanie włączona do zakresu badań podstawowych. Można mieć nadzieję, że w jednej z najbliższych swoich 
publikacjach autor wróci do tych pytań. Recenzent ze swojej strony chciałby zachęcić go do rozszerzenia ich zakresu o kwestię tego, czy badania pedagogiczne na temat kształcenia mogą być prowadzone bez uwzględnienia teoretycznego aspektu wychowania i instytucji pedagogicznych.

Z niemieckiego tłumaczył Dariusz Stępkowski. 


\section{Irena Motow}

Akademia Humanistyczno-Ekonomiczna w Łodzi

i.motow@interia.pl

\section{Sprawozdanie z konferencji naukowej: Nauki społeczne w służbie dziecka i dorosłego}

W dniu 12 czerwca 2017 r. w Akademii Humanistyczno-Ekonomicznej w Łodzi odbyła się konferencja naukowa pod tytułem Nauki społeczne w służbie dziecka $i$ dorosłego. Organizatorem była Katedra Pedagogiki Resocjalizacyjnej i Profilaktyki Społecznej Akademii Humanistyczno-Ekonomicznej w Łodzi. Patronat nad obradami objął Wojewoda Łódzki Zbigniew Rau, patronat medialny - TVP 3 Łódź. Celem konferencji była refleksja i dyskusja nad wielofunkcyjnością nauk społecznych w rozwiązywaniu problemów rozwoju człowieka.

Uroczystej inauguracji dokonała Jej Magnificencja Rektor Akademii Humanistyczno-Ekonomicznej w Łodzi dr hab. prof. nadzw. Joanna Satoła-Staśkowiak. Część plenarną rozpoczął Prezydent Akademii Humanistyczno-Ekonomicznej w Łodzi, profesor AHE, dr Makary Stasiak, z wystąpieniem pt. Kreatywność nowym wymiarem funkcjonowania człowieka. Podkreślił, że kreatywność jest niezwykle użyteczna zarówno w życiu osobistym, jak i zawodowym, ponieważ nieszablonowe twórcze myślenie pozwala znajdować rozwiązania nierozwiązywalnych problemów. Rozpatrując to w kontekście edukacji, wychowania czy opieki, koniecznością jest wytworzenie nowego myślenia i podejścia do zadań, jakie stawiane są uczestnikom tych procesów, stworzenie innowacyjnej filozofii i jej realizacja w praktyce. Idea twórczej edukacji i wychowania obejmuje szereg koncepcji i podmiotów: od twórczego ucznia, studenta, nauczyciela, pracownika, po system szkół, uczelni, instytucji wychowania i opieki. Ciekawe rozważania, zatytułowane Zamożni polscy seniorzy i ich codzienność, zaprezentowała prof. nadzw. dr hab. Helena Marzec. Autorka zwróciła uwagę, że zamożnych i bogatych Polaków niezależnie od wieku cechuje podejście pragmatyczne oraz wewnętrzna motywacja do otaczania się luksusem. Wybory tych osób są przemyślane i zaplanowane. Codzienne życie zależne jest od zdrowia, wyznaczonych celów i pasji. Dr hab. Agnieszka Lewicka-Zelent zaprezentowała walory mediacji jako jednej z form sprawiedliwości naprawczej. Podkreśliła jej inkluzyjny charakter. Ostatnie wystąpie- 
nie w części plenarnej dr Elżbiety Dul-Ledwosińskiej - Prezentacja metody Design Thinking - Myślenie projektowe - w swojej treści nawiązywało do pierwszego referatu.

W drugiej części konferencji prezentowane wystąpienia i dyskusja skupiały się wokół problemów obszarów tematycznych wskazanych w programie konferencji. Niezwykle ciekawe wystąpienie pt. Między uczelnia a rynkiem pracy - perspektywy młodych przedstawił prof. nadzw. dr hab. Daniel Kukla. Podkreślił w nim rolę edukacji, która w obecnych czasach staje się kreatorem oczekiwań rynku pracy. W następnej prelekcji dr Grażyna Tadeusiewicz wskazała na ważkość doradztwa zawodowego dla osób defaworyzowanych na rynku pracy. Kolejne wystąpienia dotyczyły wyzwań społecznych i edukacyjnych wobec problemu, jakim jest starzenie się polskiego społeczeństwa. Drugą część konferencji zdominował cykl wystąpień dotyczących wychowania, edukacji i profilaktyki dzieci i młodzieży.

W trzeciej części przeprowadzono z uczestnikami dwoje zajęć warsztatowych: Design Thinking - jak to działa (prowadziła dr Elżbieta Dul-Ledwosińska) oraz Metody nauczania rozwijające kreatywność wśród uczniów (na podstawie podręcznika opracowanego w ramach projektu INCREASE) (prowadziła dr Kamila Witerska). Warsztaty cieszyły się dużym zainteresowaniem.

Podsumowania obrad dokonała dr hab. prof. AHE Irena Motow, dziękując uczestnikom za udział i dyskusję. Konferencję o tak szerokim spektrum poruszanych problemów organizowano w AHE po raz pierwszy. Zgodnie uznano ją za udaną. Uczestnicy zwrócili uwagę na potrzebę cyklicznego organizowania spotkań na ten temat. Zaprezentowane wystąpienia zostaną opublikowane w międzynarodowym czasopiśmie elektronicznym „Kultura i Wychowanie” 2017. 


\section{Elżbieta Woźnicka}

Akademia Humanistyczno-Ekonomiczna w Łodzi

e_woznicka@wp.pl

\section{Sprawozdanie z konferencji Dialog w wychowaniu do wartości}

W dniu 3 marca 2017 roku w Akademii Humanistyczno-Ekonomicznej w Łodzi na kierunku pedagogika odbyła się konferencja pt. Dialog w wychowaniu do wartości. Współorganizatorem konferencji był Wojewódzki Ośrodek Doskonalenia Nauczycieli w Łodzi. Miała ona charakter naukowo-metodyczny. Podzielona była na trzy części. Pierwsza $z$ nich obejmowała obrady plenarne, druga - forum dobrych praktyk oraz spotkanie z autorką książek dla dzieci i młodzieży, trzecia - warsztaty dla nauczycieli. Celem konferencji była merytoryczna dyskusja nad miejscem i statusem wychowania do wartości w szkole ogólnodostępnej, w tym znalezienie odpowiedzi na pytania: jakie jest miejsce wychowania do wartości w szkole? Czy możliwy jest dialog jako szersze podejście w wychowaniu do wartości? Jakie metody i narzędzia służą realizacji dialogu w edukacji? Jakie znaczenie może mieć literatura w wychowaniu do wartości?

W problematykę konferencji wprowadziła swoim wystąpieniem pt. Dialog $w w y-$ chowaniu prof. Aldona Pobojewska. Przedstawiła ustalenia definicyjne i terminologiczne związane $\mathrm{z}$ pojęciem i rozumieniem istoty dialogu oraz aspekty teoretyczne wychowania do wartości w szkole. Wskazała na dialog nie tylko jako rozmowę, sposób komunikacji, ale również jako postawę i drogę do prawidłowych interakcji. Dr Krzysztof Kamiński w swoim wystąpieniu podjął próbę sformułowania odpowiedzi na pytanie postawione w jego tytule: Po co komu wartości? Kultura wartości w szkole - zarys aksjologiczno-pedeutologiczny. Odniósł się do dwóch pytań dotyczących wartości: teleologicznego (po co wartości?) i ontycznego (ze względu na kogo/ co mamy odwoływać się do wartości?). Zaprezentował istotowe i etymologiczne znaczenie pojęcia „kultura” oraz omówił zarys aksjologiczno-pedagogiczny kultury - aksjologiczny, ponieważ odnosimy się do wartości, a te są podstawową kategorią aksjologii właśnie, oraz pedeutologiczny, bo chcemy pojąć istotę zawodu nauczyciela/ wychowawcy. Podstawą analiz dr. Kamińskiego stało się przekonanie, że wychowanie każdorazowo jest eksperymentowaniem. Redaktor naczelna wydawnictwa Literatu- 
ra, Wiesława Jędrzejczyk, wyjaśniła z perspektywy wydawcy Jak mówić o wartościach $w$ książkach dla dzieci i młodzieży. Zaprezentowała kilka serii wydawniczych, które szczególnie poruszają kwestię wartości, są skierowane do dzieci i młodzieży. a ich głównym celem jest rozwój wrażliwości, empatii i uniwersalnych postaw młodego czytelnika. Przybliżyła zgromadzonym nazwiska współczesnych autorów piszących książki dla dzieci i młodzieży. W ramach wprowadzenia w praktykę edukacyjną, metodyczki z Wojewódzkiego Ośrodka Doskonalenia Nauczycieli w Łodzi, Bogusława Rajska i Barbara Papierz, przedstawiły program edukacyjny Przyjaciele Zippiego a uczenie o wartościach. Jest to międzynarodowy program promocji zdrowia psychicznego dla dzieci w wieku 5-8 lat, który kształtuje i rozwija ich umiejętności psychospołeczne. Uczy różnych sposobów radzenia sobie z trudnościami i wykorzystywania nabytych umiejętności w codziennym życiu oraz doskonali relacje dzieci z innymi ludźmi. Program Przyjaciele Zippiego pokazuje dzieciom, jak radzić sobie ze zmianami i wyzwaniami, jak rozwiązywać konflikty i dobrze funkcjonować w grupie. Jest to, jak dodały referentki, jedyny program, w którym z małymi dziećmi rozmawia się na temat śmierci i uczuć, jakie towarzyszą człowiekowi w sytuacji utraty kogoś bliskiego. Program pokazuje także jak ważna jest rozmowa z innymi, kiedy odczuwamy smutek lub złość, oraz jak ważne jest słuchanie innych, kiedy oni przeżywają trudne chwile. Program opiera się o zabawy, ćwiczenia i rozmowy dotyczące spraw ważnych na tym etapie życia: przyjaźni, zmian, jakie zachodzą w nas i wokół nas, sukcesów i porażek oraz sposobów radzenia sobie z trudnościami.

W ramach forum dobrych praktyk zaproszeni nauczyciele prezentowali swoje doświadczenia w obszarze pracy dotyczącym wartości i kształtowania uniwersalnych postaw swoich uczniów i wychowanków. Na temat wychowania do wielokulturowości i tolerancji wypowiedziały się nauczycielki z Gimnazjum nr 3 z Oddziałami Integracyjnymi im. Adama Mickiewicza w Zgierzu, Ewa Jaskuła i Alicja Papka-Oczkowska, które prezentowały zrealizowany ze swoimi uczniami projekt Ich duch przetrwa $w$ nas..., przedstawiający historię rodziny żydowskiej Szwarców w dwudziestoleciu międzywojennym. Doświadczeniem w pracy z trudną młodzieżą podzielili się Michał Główczyński i Maciej Mertin z Młodzieżowego Ośrodka Socjoterapii nr 3 w Łodzi. Pokazali, jak poprzez zajęcia ze wspinaczki oraz wyjazdy wysokogórskie z dziećmi z ośrodka socjoterapeutycznego można kształtować ich postawy i wpajać im uniwersalne wartości. nauczyć ich jak komunikować się w ważnych kwestiach oraz rozwijać zaufanie do innych i gór. Pedagodzy zaprezentowali swój długoterminowy projekt: $W$ drodze na szczyt. Wspinaczka jako terapia dla trudnej młodzieży Z kolei kreatywne rozwiązania we wprowadzaniu dzieci w świat wartości przedstawiła Barbara Michalska z fundacji EduKABE. W tej części konferencji odbyło się również spotkanie z autorką książek dla dzieci i młodzieży Dorotą Combrzyńską-Nogalą. Spotkanie prowadzone było przez Monikę Kamieńską. Było okazją do promocji najnowszej książki autorki, zatytułowanej Skutki uboczne eliksiru miłości. Dorota Combrzyńska-Nogala jest łodzianką, z wykształcenia polonistką i surdopedagogiem, autorką ksią- 
żek obyczajowych: Naszyjnik z Madrytu, nagrodzonej Literacką Nagrodą im. Władysława Reymonta Piątej z kwartetu oraz Wytwórni wód gazowanych. Jej książka dla dzieci - Bezsenność Jutki - otrzymała nagrodę „Książka Przyjazna Dziecku” oraz wyróżnienie w konkursie IBBY na Książkę Roku 2012, natomiast Syberyjskie przygody Chmurki zdobyły wyróżnienie w konkursach na Nagrodę Literacką im. Kornela Makuszyńskiego oraz na Książkę Przyjazną Dziecku. Powieść Możesz wybrać, kogo chcesz pożreć wpisana została na Listę Skarbów Muzeum Książki Dziecięcej. Jej najnowsza książka opisuje życie ludzi w Polsce w jednym z najtrudniejszych okresów historii współczesnej - stanie wojennym. Atmosfera beznadziei i upodlenia przez władzę skontrastowane są z sensacyjnymi wydarzeniami z życia bohaterów. Drobiazgowo opisane realia PRL-u i oddanie mikroklimatu małej miejscowości w poprzednim ustroju pokazują, jaka była Polska trzydzieści lat temu. Poza głównymi wątkami powieść inkrustowana jest wieloma drobnymi zdarzeniami, którymi żyją mieszkańcy Warty. Wraz z bohaterami czytelnik przeżywa ich historie, doznania, problemy czy radości, poznaje przesądy i wierzenia właściwe tej społeczności.

W części warsztatowej wszyscy uczestnicy mogli zdecydować o udziale w dwóch z pięciu przygotowanych warsztatów: Storytelling $w$ wychowaniu do wartości (prowadziła dr Kamila Lasocińska), Etyka w wychowaniu do wartości (prowadził dr Łukasz Zaorski-Sikora), Prawa dziecka (prowadziła mgr Barbara Papierz), Z dzieckiem $w$ świat wartości (prowadziła mgr Bogusława Rajska), Teatr Forum w pracy $z$ wartościami w gimnazjum i szkole średniej (prowadziła dr Kamila Witerska). Warsztaty były jednocześnie okazją do udziału w dyskusji dla uczestników konferencji. Konferencja cieszyła się dużym zainteresowaniem, a jej różnorodność sprawiła, że uczestnicy byli przez cały czas aktywni. 
Akademia Humanistyczno-Ekonomiczna w Łodzi od roku 2017 będzie kontynuować tradycje wydawnicze międzynarodowego elektronicznego czasopisma naukowego „Kultura i Wychowanie”.

Naszą ambicją jest wydawanie czasopisma opiniotwórczego, otwartego i dynamicznie rozwijającego się.

Obszar zainteresowań czasopisma z założenia ma szeroki zakres. Odwołuje się do zagadnień związanych z interdyscyplinarną relacją kultury i wychowania. Prezentowane wyniki badań naukowych, głównie z obszaru pedagogiki, ujmowane są w dwa bloki tematyczne rozpraw: filozoficzno-historyczne oraz teoretyczno-empiryczne.

Wersja internetowa, będąca podstawową formą publikacji, dostępna pozostaje na stronie: www.pedagogika.pl

Zespół redakcyjny 